GUILHERME CAMARGO DE OLIVEIRA

\title{
RELAÇÕES DE TRABALHO RURAL DE CURTA DURAÇÃO: ALTERNATIVAS PARA O TRABALHO RURAL COM DIGNIDADE
}

\author{
DissertaÇão de Mestrado \\ Orientador: Prof. Titular Sergio Pinto Martins
}

FACULDADE DE DIREITO DA USP SÃO PAULO 2012 


\title{
GUILHERME CAMARGO DE OLIVEIRA
}

\section{RELAÇÕES DE TRABALHO RURAL DE CURTA DURAÇÃO: ALTERNATIVAS PARA O TRABALHO RURAL COM DIGNIDADE}

\author{
Dissertação de Mestrado apresentada à Banca Examinadora da \\ Faculdade de Direito da Universidade de São Paulo, como \\ exigência parcial para a obtenção do título de Mestre em Direito, \\ sob a orientação do Prof. Titular Sergio Pinto Martins
}

FACULDADE DE DIREITO DA USP

SÃO PAULO

2012 
Banca Examinadora 


\section{Dedicatória}

À minha família especialmente meus pais e irmãs, pelo amor, pelo exemplo, por tudo.

Ao "boia-fria". 
Agradecimentos

A Deus e à família.

Ao Dr. Sérgio Pinto Martins, pela oportunidade, orientação e apoio para a concretização dessa dissertação.

Ao Dr. Nelson Mannrich, pelo incentivo, inspiração e inestimável suporte ao meu desenvolvimento pessoal e profissional.

A todos os professores do curso, que contribuíram, direta ou indiretamente, para a elaboração do presente trabalho.

Aos funcionários das bibliotecas, especialmente a do Largo de São Francisco; amigos que, com zelo e generosidade, permitem a perpetuação e produção do conhecimento.

Aos colegas de curso, pelo companheirismo e amizade.

Ao Grupo Rural, pela amizade, ensinamentos e por compartilhar o ideal de tutela da dignidade dos trabalhadores rurais. 


\section{RESUMO}

O presente trabalho examina trabalho avulso, consórcio de empregadores rurais e contrato de trabalho rural por pequeno prazo enquanto alternativas para a formalização da relação de trabalho rural de curta duração. Sob a ótica do trabalho decente e da preservação da dignidade do trabalhador, preocupa-se o estudo em pesquisar a adequação do ordenamento jurídico nacional à realidade do pequeno produtor rural e do trabalhador por ele contratado, para atividades que duram não mais que alguns dias ou semanas. A adaptabilidade do direito à realidade e a adequação dos modelos jurídicos às necessidades dos atores sociais são percebidas como condição necessária para a proteção da dignidade do trabalhador rural. Analisa-se de maneira crítica cada uma das três figuras jurídicas, a fim de apontar em que medida estão adaptadas às peculiaridades do campo e quanto estão aptas a tutelar os direitos fundamentais dos trabalhadores rurais. A partir de tal verificação, sugerem-se elementos a serem considerados na busca de alternativas viáveis para a formalização das relações de trabalho rural de curta duração.

Palavras-chave: Trabalho rural de curta duração; dignidade do trabalhador rural; trabalho avulso; consórcio de empregadores rurais; contrato de trabalho rural por pequeno prazo. 


\begin{abstract}
The present paper examines "trabalho avulso", "consórcio de empregadores rurais" and "contrato de trabalho rural por pequeno prazo" as alternatives to formalize the rural work with short duration relationship. From the perspective of decent work and preserving the workers' dignity, this study is concerned in researching the legal national system adequacy with the small rural producer's reality and workers contracted by it for activities that do not last more than a few days or weeks. The adaptability of the right to the reality and legal models adequacy to social actors' needs are perceived as a necessary condition for the protection of the rural workers' dignity. Each of the three legal figures are critically analyzed to point to what extent are adapted to the peculiarities of the field and how much they are able to protect the rural workers fundamental rights. Upon such verification, elements are suggested to be considered in the search of viable alternatives to formalize the relations of rural work of short duration.
\end{abstract}

Keywords: Short duration rural work; rural worker's dignity; "trabalho avulso"; "consórcio de empregadores rurais"; "contrato de trabalho rural por pequeno prazo". 


\section{SUMÁRIO}

INTRODUÇÃO

\section{TRABALHO RURAL E DIGNIDADE: ADAPTABILIDADE DO DIREITO DO}

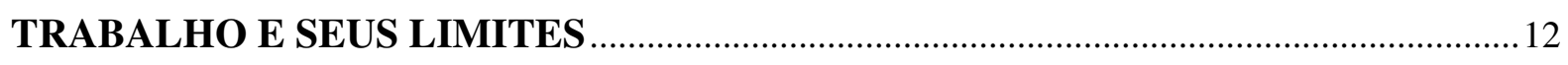

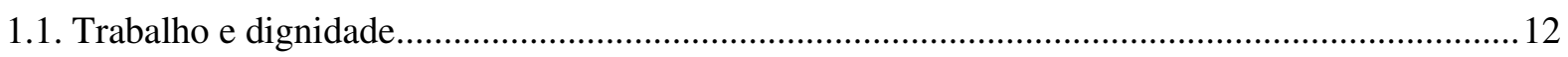

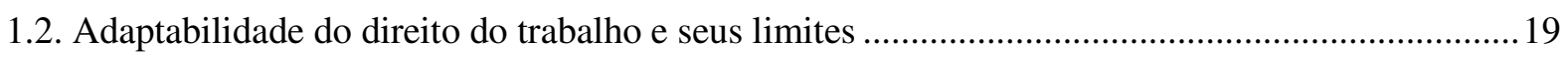

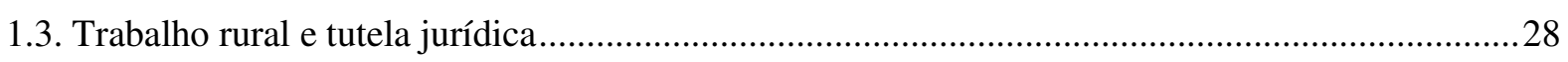

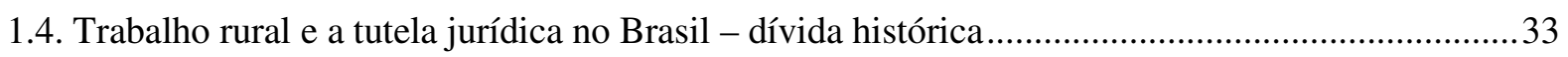

1.4.1. Inadequação do direito do trabalho para as atividades rurais de curta duração -

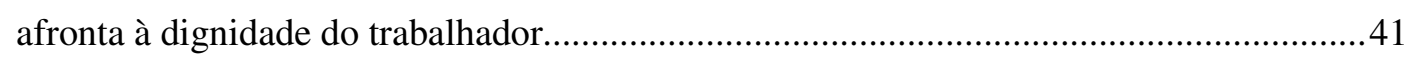

1.4.1.1. A questão das cooperativas rurais de mão de obra ..............................................49

2. ELEMENTOS DA RELAÇÃO DE TRABALHO RURAL ..............................................56

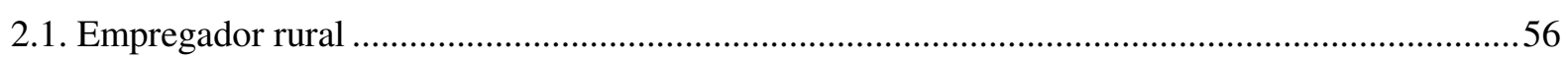

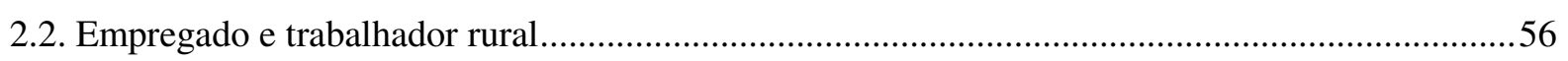

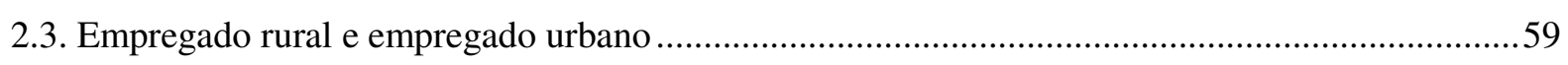

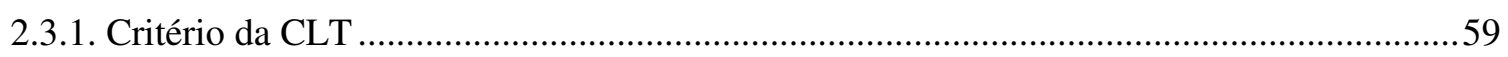

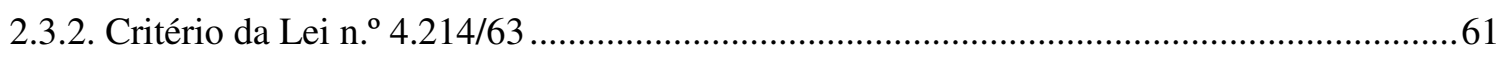

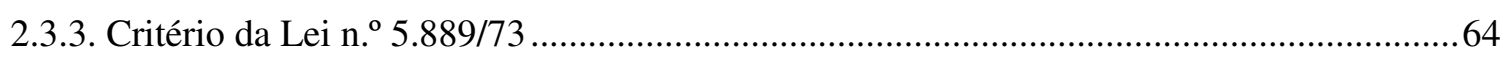

2.4. Extensão da aplicação dos preceitos da Lei . $^{\circ} 5.889 / 73$ aos trabalhadores rurais .........................69

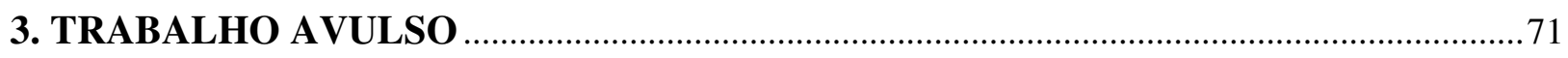

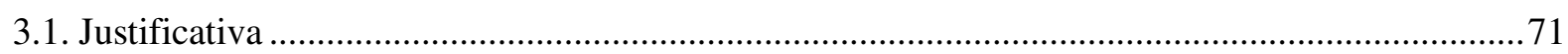

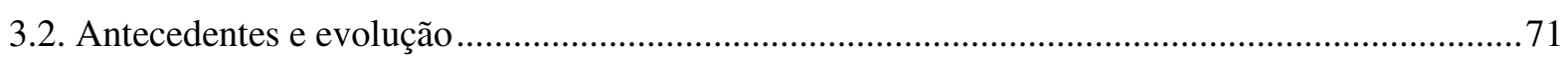

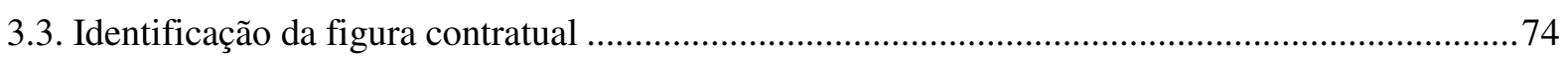

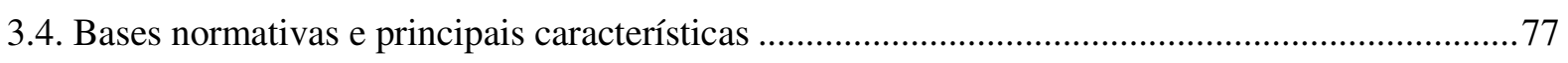

3.5. Trabalho avulso para serviços rurais não ligados à movimentação de mercadoria -

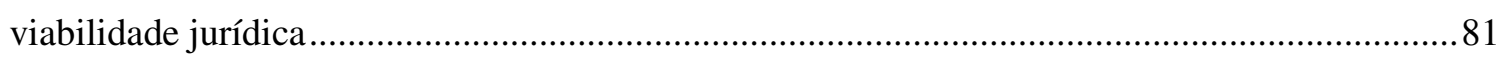

3.6. Trabalho avulso para serviços rurais não ligados à movimentação de mercadoria -

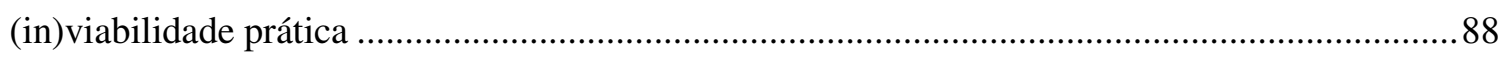

4. CONSÓRCIO DE EMPREGADORES RURAIS ..............................................................93

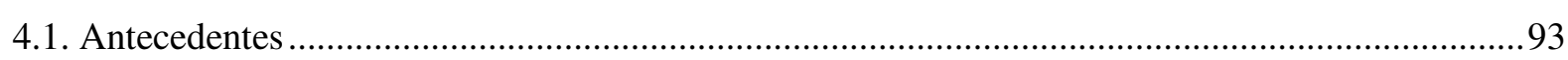

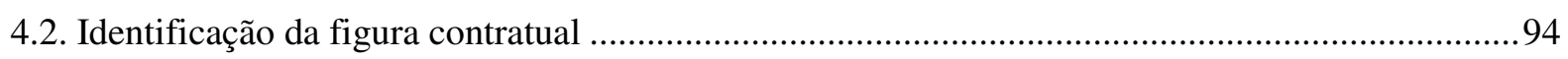

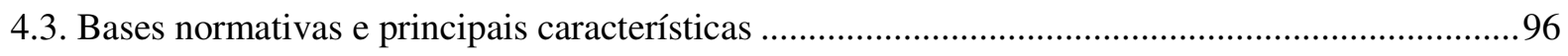

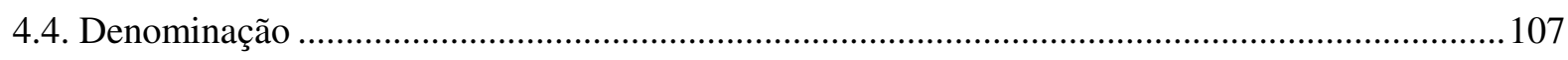

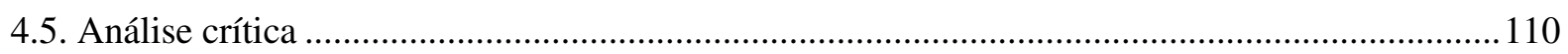


5. CONTRATO DE TRABALHO RURAL POR PEQUENO PRAZO .................................122

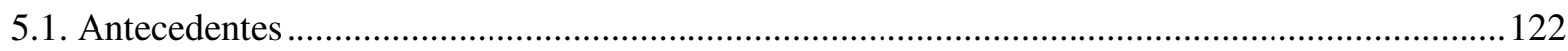

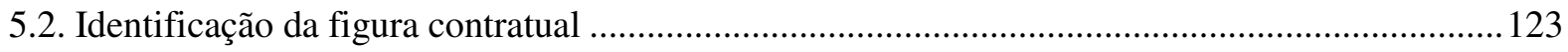

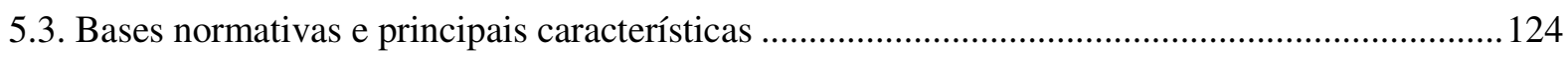

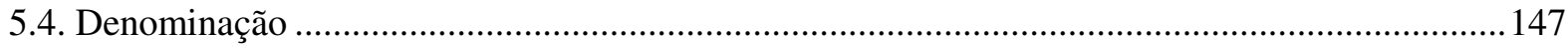

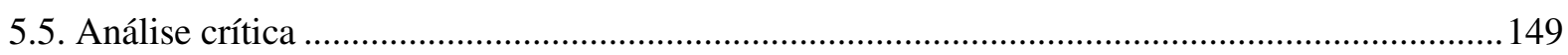

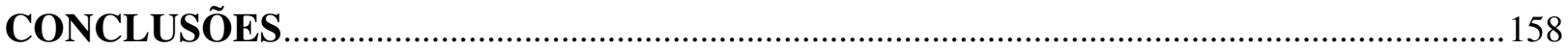

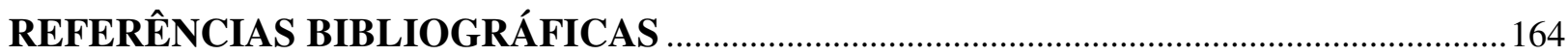




\section{INTRODUÇÃO}

O presente trabalho tem por escopo estudar o sistema de trabalho avulso, o consórcio de empregadores rurais e o contrato de trabalho rural por pequeno prazo como alternativas para a formalização das relações de trabalho rural de curta duração e, por conseguinte, para a tutela de direitos básicos do trabalhador do campo e sua dignidade. Partindo-se da constatação de que a formalização é imprescindível para a efetiva proteção da dignidade do trabalhador, busca-se compreender cada uma das três figuras jurídicas e a respectiva adequação para as atividades rurais de curta duração, notoriamente marcadas pela informalidade e por precárias condições de trabalho.

O tema se limita às relações de trabalho de curto período, geralmente demandadas por pequenos produtores rurais, pessoas físicas, durante apenas alguns dias ou semanas. Não faz parte do objeto de estudo, assim, o labor prestado a grandes e estruturados produtores rurais, ou para a agroindústria. Para estes, o porte econômico e a grande quantidade de tarefas a serem realizadas ensejam a pertinência de contratos de trabalho duradouros, viabilizando-se o contrato de safra ou mesmo por prazo indeterminado.

Com tais limites, o presente trabalho não se presta a analisar os efeitos diretos da crescente mecanização nos processos produtivos das lavouras, pois, pelo seu custo, esse processo se faz sentir mais fortemente entre os produtores rurais de maior capacidade financeira. Merece registro apenas a consequência indireta que o aumento da produtividade dos grandes produtores, oriunda da mecanização, acarreta sobre os pequenos, acirrando a concorrência e exigindo a busca pela redução de custos. Também não serão abordadas as relações de parceria e arrendamento rural, por não serem contratos propícios para serviços de curta duração.

Certamente a transformação da realidade dos trabalhadores rurais passa pela sua organização sindical e pela capacidade de representação e negociação dos sindicatos, como bem percebido pela Organização Internacional do Trabalho. Entretanto, escapa aos limites do tema a discussão a respeito do modelo sindical brasileiro, marcado pela incongruência que amarra a liberdade sindical com as cordas herdadas do corporativismo.

O estudo se justifica a partir das precárias condições em que os trabalhadores rurais, principalmente os contratados por curtos períodos, atuam. A situação é de conhecimento 
público e notório, estando já disseminado na sociedade o uso da expressão "boia-fria" para designar esse tipo de trabalhador, que presta sua atividade laboral sem a devida proteção jurídica. Tendo a Constituição da República de 1988 prestigiado o valor social do trabalho e aclamado a dignidade da pessoa humana como fundamento da República, faz-se pertinente o presente estudo, que almeja confrontar tais comandos constitucionais com a realidade dos chamados "boias-frias" e as alternativas de formalização dessa relação trabalhista. O estudo se justifica, outrossim, por pretender contrapor o modo pelo qual o ordenamento jurídico pátrio observa as relações de trabalho rural de curta duração e os primados do Trabalho Decente, nos moldes defendidos pela Organização Internacional do Trabalho.

Utilizam-se os métodos dedutivo e indutivo, analisando-se de maneira crítica a legislação, a doutrina e a jurisprudência pertinentes, atentando-se principalmente para a adequação entre as normas e as peculiaridades do ambiente rural brasileiro e o trabalho nele praticado. Para desenvolver o tema, o presente trabalho se divide em cinco capítulos, além desta introdução e da conclusão. Inicia-se apreciando a relação entre trabalho, dignidade humana e sua proteção jurídica. Aborda-se a necessária aproximação entre norma e realidade, com foco na adaptabilidade do Direito do Trabalho às relações econômicas de produção.

São indicados os impactos do avanço tecnológico e da globalização nas relações de trabalho, impulsionando o Direito do Trabalho a se adaptar às novas formas de produção. Procura-se, com isso, reforçar a constatação: se para as novas formas de trabalho o direito deve estar apto, com modelos contratuais tão ágeis quanto exige a tecnologia, preservando sempre a dignidade dos trabalhadores, com mais evidência deve também estar apto a regular antigas formas de trabalho, como a atividade campesina por pequeno prazo, tutelando também a dignidade dos obreiros nesta situação.

Assim, a inadequação do ordenamento jurídico trabalhista pátrio para lidar com o trabalho rural de curta duração é percebido como uma das causas da informalidade e das constantes violações a direitos fundamentais dos trabalhadores rurais. A evolução histórica do Direito do Trabalho e da estrutura agrária brasileira auxilia o entendimento das causas dessa inadequação.

Com a Constituição da República de 1988, o ordenamento jurídico deu largo passo para a proteção do trabalhador rural; entretanto, o ideal de preservação de direitos não atingiu grande efetividade. A larga utilização de cooperativas de mão de obra como meras 
intermediadoras, em meados da década de 1990, é apresentada como exemplo do efeito nefasto que a inadequação entre realidade e direito pode provocar, com supressão de direitos básicos e afronta à dignidade do trabalhador rural.

No capítulo seguinte são abordados os elementos da relação de trabalho rural, análise que se insere como base para o estudo das três figuras jurídicas a serem estudadas posteriormente. O exame de importantes conceitos, como empregador rural, empregado e trabalhador rural, trabalho urbano e trabalho rural, entre outros, mostra-se propício para alicerçar a compreensão do tema.

A seguir, dedica-se um capítulo para cada figura jurídica a ser estudada. Inicialmente o trabalho avulso é abordado. Justifica-se seu estudo apesar de, tradicionalmente, se tratar de modelo jurídico aplicável principalmente à zona portuária. Ocorre que em 2009 surgiu, no ordenamento brasileiro, norma tratando do trabalho avulso em áreas não ligadas ao setor portuário, aventando-se a possibilidade de se utilizar o sistema para os serviços rurais de pequena duração. Após o trabalho avulso estuda-se o consórcio de empregadores rurais e, em seguida, o contrato de pequeno prazo, instituído a partir da inserção do artigo 14-A na Lei n. ${ }^{\circ}$ 5.889/73.

Pretende-se analisar, de maneira crítica, os méritos e imperfeições de cada figura, sua aplicabilidade e adequação às peculiaridades do meio rural e, assim, a capacidade de tutelar efetivamente a dignidade do trabalhador. Desse modo, busca-se apontar elementos que merecem ser observados, e que devem ser abandonados, na procura de modelos jurídicos para o trabalho rural de curta duração, capazes de proteger os direitos mínimos dos rurícolas e, ao mesmo tempo, preservar a viabilidade econômica dos pequenos produtores rurais, fonte dos postos de trabalho. 


\section{TRABALHO RURAL E DIGNIDADE: ADAPTABILIDADE DO DIREITO DO TRABALHO E SEUS LIMITES}

\subsection{Trabalho e dignidade}

A Constituição da República de 1988 situa os direitos trabalhistas dentro do Título dos "Direitos e Garantias Fundamentais", sinalizando a pertinência de se observar a relação trabalhista a partir de patamar diferenciado, de tutela de direitos humanos. Estes constituem, nos dizeres de Ingo Wolfgang Sarlet ${ }^{2}$, "exigência e concretização do princípio da dignidade da pessoa humana".

A expressão dignidade humana encontra significados em diversos campos do conhecimento humano, como religioso, ético, filosófico, jurídico ${ }^{3}$. Carregando forte viés de acompanhamento da evolução histórica e cultural da humanidade ${ }^{4}$, a dignidade já foi considerada pela doutrina cristã como concessão divina, por ter sido o homem criado à imagem e semelhança de Deus, ou dependente da posição social, conforme pensamento filosófico da Antiguidade Clássica ${ }^{5}$. Modernamente, o princípio jurídico da dignidade humana encontra fundamento no pensamento de Immanuel Kant ${ }^{6}$, baseado na natureza racional do homem e sua capacidade de autodeterminação, a partir do exercício da própria vontade. Assim, cada ser humano é um fim em si mesmo, não podendo ser considerado instrumento ou meio para obtenção de fins externos a ele próprio ${ }^{7}$. Possui um valor intrínseco e único, não mensurável nem passível de equiparação a preço ou a algo que o possa substituir. Nesse sentido, após apontar a natureza multidimensional ${ }^{8}$ da dignidade da

\footnotetext{
${ }^{1}$ A elevação dos direitos sociais a nível constitucional, como movimento internacional, marcou o final da década de 1910, especialmente com a Constituição Mexicana de 1917 e a Alemã de 1919, conhecida Constituição de Weimar. Ari Possidônio Beltran apresenta interessante estudo sobre o Direito do Trabalho nas Constituições de países europeus e latinoamericanos. BELTRAN, Ari Possidônio. Direito do trabalho e direitos fundamentais. São Paulo: LTr. 2002. p. 71 a 121.

${ }^{2}$ SARLET, Ingo Wolfgang. Dignidade da pessoa humana e direitos fundamentais na Constituição Federal de 1988. 9. ed. Porto Alegre: Livraria do Advogado, 2011. p. 100.

${ }^{3}$ SANTOS, Ronaldo Lima dos. Dignidade humana da criança e do adolescente e as relações de trabalho. In: FREITAS JR., Antonio Rodrigues (Org.) Direito do trabalho e direitos humanos. São Paulo: BH Ed., 2006. p. 542.

${ }^{4}$ SARLET, Ingo Wolfgang. op. cit., p. 68-69.

${ }^{5}$ Id. Ibid., p. 34.

${ }^{6}$ SANTOS, Ronaldo Lima dos. op. cit., p. 541.

${ }^{7}$ SARLET, Ingo Wolfgang. op. cit., p. 40-41.

${ }^{8}$ Entre as diversas dimensões: a ontológica, a histórico-cultural, e sua dupla face negativa (abstenção de violação) e prestacional (promoção) em face do Estado e de particulares. SARLET, Ingo Wolfgang. op. cit., p. 72.
} 
pessoa humana e afirmar se tratar de uma ideia em permanente reconstrução, Sarlet $^{9}$ oferece uma definição de dignidade humana:

\begin{abstract}
"Qualidade intrínseca e distintiva reconhecida em cada ser humano que o faz merecedor do mesmo respeito e consideração por parte do Estado e da comunidade, implicando, neste sentido, um complexo de direitos e deveres fundamentais que assegurem a pessoa tanto contra todo e qualquer ato de cunho degradante e desumano, como venham a the garantir as condições existenciais mínimas para uma vida saudável, além de propiciar e promover sua participação ativa e co-responsável nos destinos da própria existência e da vida em comunhão com os demais seres humanos, mediante o devido respeito aos demais seres que integram a rede da vida."
\end{abstract}

Alguns pontos da definição merecem destaque. A dignidade é uma qualidade, ou seja, "atributo que determina a essência ou a natureza de algo ou alguém ${ }^{10 "}$. Esse atributo inato faz do ser humano merecedor de um complexo de direitos, com os correspondentes deveres. Os direitos devem ser suficientes para assegurar não apenas a abstenção de tratamentos degradantes, mas também a existência de condições para se gozar de uma vida saudável. A ideia de vida saudável deve ser buscada, como faz o próprio autor ${ }^{11}$, nos parâmetros da Organização Mundial da Saúde, que menciona completo bem-estar físico, mental e social.

É nesse contexto que os Direitos Fundamentais, representando o reconhecimento jurídico dos Direitos Humanos ${ }^{12}$, se constituem em exigência e concretização do princípio da dignidade da pessoa humana.

Devendo ser observada em todos os momentos da atividade humana, a dignidade está intimamente ligada às relações de trabalho, figurando os direitos trabalhistas, como visto acima, entre os direitos fundamentais constitucionalmente assegurados. Há razões suficientes para tanto. O trabalho é, das formas pelas quais o ser humano se relaciona na sociedade, uma das mais importantes. Além de consumir boa parte do tempo do convívio em sociedade, é em função dele que o indivíduo constrói sua posição social, seu universo

\footnotetext{
${ }^{9}$ SARLET, Ingo Wolfgang. op. cit., p. 73.

${ }^{10}$ HOUAISS, Antonio. VILLAR, Mauro de Salles. Minidicionário Houaiss da língua portuguesa. 2. ed. Rio de Janeiro: Objetiva, 2004. p. 612.

${ }^{11}$ SARLET, Ingo Wolfgang. op. cit., p. 73.

${ }^{12}$ Conforme Fábio Konder Comparato, há distinção, elaborada pela doutrina germânica, entre direitos humanos e direitos fundamentais: "Estes últimos são os direitos humanos reconhecidos como tal pelas autoridades às quais se atribui o poder político de editar normas, tanto no interior dos Estados quanto no plano internacional; são os direitos humanos positivados nas Constituições, nas leis, nos tratados internacionais.". COMPARATO, Fábio Konder. A afirmação histórica dos direitos humanos. São Paulo: Saraiva, 1999. p. 46.
} 
de amizades e relacionamento. Salvo raras exceções, é a partir do trabalho que encontra, o ser humano, seu lugar na escala social. Nesse sentido, o trabalho é um dos mais relevantes componentes do quadro de direitos correspondente à dignidade da pessoa humana, figurando como elemento que auxilia a própria identificação do indivíduo. Não por outra razão, nas peças forenses, qualifica-se a pessoa humana não apenas pelo seu nome, endereço, estado civil, mas também por sua profissão. É dizer, a atividade laboral faz parte da própria identidade do homem em sociedade ${ }^{13}$.

Além disso, no sistema capitalista, é através do trabalho que a maioria da população adquire condições materiais de suprir suas necessidades básicas ${ }^{14}$. A ligação estreita entre trabalho e dignidade se agiganta, outrossim, por estarem presentes, na relação laboral, diversos momentos em que ela é posta em cheque, dispondo a legislação do trabalho de instrumentos de proteção a direitos como segurança, saúde, intimidade e outros imprescindíveis para a sadia qualidade de vida ${ }^{15}$. Tal proteção "significa concretizar, nas relações de trabalho, os direitos fundamentais que asseguram ao ser humano um patamar mínimo de vida digna." 16.

Ademais, a própria reiterada menção à dignidade da pessoa humana feita pela Constituição da República, como fundamento da República (art. $1^{\circ}$, III) e finalidade da ordem econômica e financeira (art. 170), demonstra que em todos os momentos da atividade do homem o valor dignidade deve ser preservado, inclusive nas relações de trabalho. Assim, o trabalho é visto constitucionalmente como valor social ${ }^{17}$, fundamento da República (art. $1^{\circ}$, IV), da ordem econômica (art. 170 caput), e base da ordem social (art.193). Nesse sentido, Vólia Bonfim Cassar ${ }^{18}$ :

\footnotetext{
${ }^{13}$ Gabriela Neves Delgado, considerando o trabalho necessário para a constituição da identidade social do homem enquanto sujeito de direitos afirma: "O trabalho, como elemento que concretiza a identidade social do homem, possibilitando-lhe autoconhecimento e plena socialização, é da essência humana.”. DELGADO, Gabriela Neves. Direito fundamental ao trabalho digno. São Paulo: LTr, 2006. p. 21-26.

${ }^{14}$ MONTANHANA, Beatriz. A constitucionalização dos direitos sociais: a afirmação da dignidade do trabalhador. In: FREITAS JR., Antonio Rodrigues (Org.). Direito do trabalho e direitos humanos. São Paulo: BH Ed., 2006. p. 64-65.

${ }^{15}$ Raimundo Simão de Melo retrata a íntima ligação entre o princípio da dignidade da pessoa humana e o meio ambiente de trabalho. MELO, Raimundo Simão de. Dignidade da pessoa humana e meio ambiente de trabalho. Revista de Direito do Trabalho, São Paulo, v. 31, n. 117, p. 204-220, jan./mar. 2005.

${ }^{16}$ DELGADO, Gabriela Neves; MIRAGLIA, Lívia Mendes Moreira. A tendência expansionista do Direito do trabalho: breve análise a partir do fundamento de proteção ao trabalho previsto na Constituição Federal de 1988. Revista Síntese Trabalhista e Previdenciária, Brasília, v. 22, n. 263, p. 87, maio 2011.

${ }^{17}$ DELGADO, Gabriela Neves. O trabalho enquanto suporte de valor. Revista da Faculdade de Direito da Universidade Federal de Minas Gerais, Belo Horizonte, n. 49, p. 77-97, jul./dez. 2006.

${ }^{18}$ CASSAR, Vólia Bonfim. A globalização e a crise do direito do trabalho: limite à flexibilização. Revista Magister de Direito Trabalhista e Previdenciário, Porto Alegre, v. 3, n. 16, p. 20, jan./fev. 2007.
} 
"A garantia de direitos mínimos ao trabalhador faz parte de um conjunto de valores humanos civilizatórios (mínimo existencial), que encontra respaldo no princípio da dignidade da pessoa humana previsto constitucionalmente como maior patrimônio da humanidade."

Parte-se da premissa, portanto, de que qualquer prestação de serviço, seja sob molde empregatício ou não, deve sempre se dar de maneira a preservar e promover o respeito ao conjunto de direitos básicos conformadores da dignidade do trabalhador. Para tanto, faz-se necessário o reconhecimento jurídico da atividade empreendida, ou seja, sua subsunção a determinado modelo normativo, a partir do qual são estabelecidos os respectivos direitos. Deve haver a pertinente correspondência entre fato e norma, encaixando-se aquele em determinada figura jurídica, como trabalho autônomo, temporário, empregatício, ou outro, conforme as circunstâncias fáticas. Definido o molde jurídico, pode-se determinar, então, quais os direitos assegurados e deveres correspondentes.

A relação de trabalho, prestado por pessoa física, que não se encaixa em molde jurídico algum, deixa de estar inserida em um quadro prévio de direitos e deveres ${ }^{19}$, ficando à mercê da liberdade total de estipulação das partes, mesmo cenário liberal do período da Revolução Industrial, correndo-se o risco de se fazerem presentes as mesmas condições de afronta à dignidade da pessoa humana perpetradas naquela época.

Entre os modelos jurídicos de relação de trabalho, o empregatício, embora possa se dar tacitamente (art. 442 da CLT), exige a formalização do contrato, mediante anotação em Carteira de Trabalho e Previdência Social (CTPS) (art. 29 da CLT) e registro em livro, ficha ou sistema eletrônico (art. 41 da CLT). Sabe-se que, nesse caso, são dos fatos, não da formalidade, que decorrem os direitos, de acordo com o princípio da primazia da realidade. Não obstante, a formalização constitui o primeiro passo para que o obreiro, sem ser obrigado a recorrer ao Judiciário, adquira a condição inequívoca de empregado, é dizer, seja reconhecido pelo ordenamento jurídico como tal. A partir disso, pode contar com todos os respectivos direitos, principalmente os relacionados à sua dignidade.

O mesmo se dá com as demais modalidades de trabalho que, embora dispensando as formalidades empregatícias, trazem consigo determinadas exigências, como o contrato

\footnotetext{
${ }^{19}$ Nas palavras de Gabriela Neves Delgado, a regulamentação jurídica é "instrumento necessário para que a dignidade do trabalhador (condição que lhe é intrínseca enquanto ser humano) esteja respeitada no marco do Estado Democrático de Direito.". DELGADO, Gabriela Neves. Direito fundamental ao trabalho digno, cit., p. 29.
} 
escrito do trabalho temporário, a supervisão da entidade de ensino do estágio, a inscrição do avulso, entre outros. Assim, para cada modelo jurídico de relação de trabalho há correspondentes e adequadas medidas para o devido reconhecimento jurídico, sem as quais, resta ao trabalhador a informalidade e o recurso ao judiciário. Nesse contexto, a prestação laboral desacompanhada de tais medidas, ou seja, o trabalho informal, representa a negação do reconhecimento jurídico espontâneo e independente da intervenção judicial. Mais que isso, representa, consequentemente, a negação dos direitos decorrentes daquele reconhecimento. Conclui-se estarem, a dignidade e a formalização da atividade laboral, intrinsecamente ligadas, sendo esta o primeiro passo para a proteção daquela. A reforçar o argumento, Gabriela Neves Delgado ${ }^{20}$ afirma ser a regulamentação jurídica a "forma mais eficiente de viabilização do trabalho digno". Segundo a autora, o "direito ao trabalho regulado é que viabilizará, em termos formais, a proteção da dignidade."21.

Assim, cabe ao Direito regulamentar qualquer atividade laboral ${ }^{22}$, prevendo modelos jurídicos, como por exemplo contrato de emprego, de trabalho avulso, de trabalho temporário, entre outros, para garantir um patamar mínimo, ou seja, assegurar, pelo menos, os direitos de indisponibilidade absoluta, para todo tipo de trabalhador ${ }^{23}$. Diante desse quadro, o Direito do Trabalho deve se manter alerta para acompanhar as modalidades de prestação de serviço desenvolvidas pela sociedade, devendo estar adaptado à realidade e, mais que isso, ser adaptável à evolução desta, para que possa garantir a dignidade do trabalhador em todas as formas de relação trabalhista, mesmo as não subordinadas ${ }^{24}$.

No mesmo sentido, Francisco Pedro Jucá ${ }^{25}$ aponta, tratando da necessária adaptação do Direito do Trabalho em função do processo de globalização e mundialização:

"No campo do Direito do Trabalho, então, é preciso que a concepção realmente se flexibilize, não como tradicionalmente se têm dito pela supressão de direitos e garantias, gerando mais insegurança e conflitos,

\footnotetext{
${ }^{20}$ DELGADO, Gabriela Neves. Direito fundamental ao trabalho digno, cit., p. 26.

${ }^{21}$ Id., loc. cit.

${ }^{22}$ Id. O trabalho enquanto suporte de valor, cit., p. 88.

${ }^{23}$ Id. Ibid., p. 91.

${ }^{24}$ A ideia de universalização do Direito do Trabalho para regular modalidades de atividade laboral diversas da empregatícia é defendida, entre outros, por Gabriela Neves Delgado: "A proposta é a de evolução do Direito do Trabalho pela universalização de sua abrangência normativa, ainda que respeitados patamares distintos de proteção jurídica às relações de trabalho. (...) O objetivo proposto é a universalização de direitos trabalhistas para os inúmeros e diversificados tipos de trabalhadores, além do clássico empregado. Contudo, obviamente, como natural no Direito, algumas exceções ou adequações deverão ser feitas, exatamente em decorrência da diferença, às vezes grande, do modus operandi de cada uma das modalidades de trabalho existentes.”. DELGADO, Gabriela Neves. Direito fundamental ao trabalho digno, cit., p. 219.

${ }^{25}$ JUCÁ, Francisco Pedro. Renovação do direito do trabalho: abordagem alternativa à flexibilização. São Paulo: LTr. 2000. p. 90.
} 
mas no sentido de adaptabilidade, ou seja, de construir um instrumental protetivo que seja realmente capaz de alcançar as variações e mutabilidades impostas pelo processo, sem abdicar de imprimir às relações o necessário conteúdo ético, que é indispensável à manutenção da ordem social.”.

Nessa conjuntura, importa destacar a noção de Trabalho Decente, preconizada pela Organização Internacional do Trabalho a partir de 1999, ano da $87^{\text {a }}$ Conferência Internacional do Trabalho ${ }^{26}$. Trabalho decente abarca quatro elementos ${ }^{27}$, relacionados especialmente com: a) pleno emprego ${ }^{28}$ ou trabalho, b) proteção social, c) direitos fundamentais dos trabalhadores e d) diálogo social.

De maneira extremamente resumida pode-se afirmar que o primeiro elemento diz respeito à possibilidade de trabalhar, é dizer, quantidade e disponibilidade de postos de trabalho. Mais que isso, refere-se também a um patamar mínimo de remuneração pelo trabalho, que permita a subsistência digna do trabalhador e sua família. Refere-se também a condições satisfatórias de segurança e saúde no trabalho ${ }^{29}$. Proteção social, o segundo elemento, equivale à inclusão no sistema de Previdência Social, amparando o trabalhador nas situações de doença, maternidade, velhice, morte e outros riscos ${ }^{30}$. O terceiro elemento diz respeito à proibição de discriminação e de trabalho forçado e infantil ${ }^{31}$. Por fim, diálogo social se refere à possibilidade de voz dos trabalhadores perante os empregadores e autoridades públicas, sendo fundamental a liberdade sindical e a negociação coletiva ${ }^{32}$.

Concretizando a missão histórica da OIT de fomentar a justiça social e os direitos humanos e trabalhistas reconhecidos internacionalmente ${ }^{33}$, a defesa do trabalho decente encontra sustentação na ideia de que não basta quantidade de trabalho, postos de ocupação, quaisquer que sejam, e em quaisquer condições. Além disso, deve haver qualidade de trabalho, é dizer, o trabalho deve ser prestado dentro de determinadas condições, com direitos básicos, que assegurem a dignidade do trabalhador ${ }^{34}$.

\footnotetext{
${ }^{26}$ GHAI, Dharam. Trabajo decente: concepto e indicadores. Revista Internacional del Trabajo, Ginebra, v. 122, n. 2, p. 125-160, 2003. p. 125.

${ }^{27}$ Id., loc. cit., p. 125.

${ }^{28}$ FIELDS, Gary S. El trabalho decente y las políticas de desarrollo. Revista Internacional Del Trabajo. Ginebra. v. 122. n. 2. p. 263-90. 2003. p. 263.

${ }^{29}$ GHAI, Dharam. op. cit., p. 126-135.

${ }^{30}$ Id. Ibid., p. 135-138.

${ }^{31}$ Id. Ibid., p. 138-146.

${ }^{32}$ Id. Ibid., p. 146-149.

${ }^{33}$ FIELDS, Gary S. El trabalho decente y las políticas de desarrollo. Revista Internacional del Trabajo, Ginebra, v. 122, n. 2, p. 263, 2003.

${ }^{34}$ Id. Ibid., p. 267-268.
} 
Os direitos mínimos dos trabalhadores estão previstos em diversos diplomas internacionais, podendo-se $\operatorname{citar}^{35}$ : arts. XXIII, XXIV e XXV da Declaração Universal dos Direitos Humanos; art. 22 do Pacto Internacional dos Direitos Civis e Políticos ; art. $7^{\circ}$ do Pacto Internacional dos Direitos Econômicos, Sociais e Culturais; arts. $5^{\circ}, 6^{\circ}$ e 26 do Pacto de San José da Costa Rica e arts. $6^{\circ}, 7^{\circ}$ e $8^{\circ}$ do Protocolo de San Salvador. Analisando tais diplomas e ainda com base em algumas convenções fundamentais da OIT, José Claudio Monteiro de Brito Filho ${ }^{36}$ relaciona diversos direitos mínimos do trabalhador, como remuneração justa, preservação da saúde e segurança do trabalhador, limitação de jornada e existência períodos de repouso, liberdade sindical e proteção contra riscos sociais.

Para a proteção desse patamar mínimo é imprescindível que a relações de trabalho sejam formalizadas, enquadradas em determinado modelo jurídico que estabeleça um quadro basilar de direitos e deveres.

A formalização da relação de trabalho será capaz de garantir, ao menos em parte, os quatro elementos do conceito de trabalho decente, pois será possível a previsão de uma remuneração mínima, condições de segurança e saúde, integração ao sistema previdenciário, proibição de condições degradantes e inserção no sistema de representação sindical. Garante-se um piso de direitos que, não obstante a possibilidade de desrespeito, constitui um arcabouço de tutela ao hipossuficiente. A informalidade, ao contrário, situa o trabalhador ao largo da previsão jurídica, o expõe à situação de sequer ter um piso em que se apoiar para pleitear seus direitos, pois não está sequer enquadrado em um modelo jurídico.

Por vezes, a estimular a completa informalidade da relação laboral está a inadequação do Direito, sua inadaptabilidade a determinadas situações concretas que, por peculiares e especiais, não encontram, entre os modelos jurídicos, encaixe perfeito ou satisfatório. Reforça-se, assim, a necessidade do Direito do Trabalho estar atento às relações de produção existentes na sociedade, amoldando-se e adaptando-se de modo a

\footnotetext{
${ }^{35}$ DELGADO, Gabriela Neves. Direito fundamental ao trabalho digno, cit., p. 211-212.

${ }^{36}$ Segundo o autor, os direitos básicos, mínimo necessário para se ter trabalho decente, são: no plano individual - direito ao trabalho, liberdade de escolha do trabalho, igualdade de oportunidades para e no exercício do trabalho, direito de exercer o trabalho em condições que preservem a saúde do trabalhador, direito a justa remuneração, direito a justas condições de trabalho, principalmente limitação de jornada e existência de períodos de repouso, proibição do trabalho infantil; no plano coletivo, a liberdade sindical; no plano da seguridade, a proteção contra o desemprego e outros riscos sociais. BRITO FILHO, José Claudio Monteiro de. Trabalho decente. Revista do Tribunal Regional do Trabalho da 8 a Região, Belém, v. 37, n. 73, p. 97-101, jul./dez. 2004.
} 
servir como instrumento para a redução da informalidade ${ }^{37}$, fomentando não a marginalização de trabalhadores, mas a preservação da sua dignidade e o trabalho decente.

\subsection{Adaptabilidade do direito do trabalho e seus limites}

Breve análise a respeito da adaptabilidade das normas trabalhistas e seu limite se faz pertinente à medida que, no presente estudo, aborda-se a distância entre o direito e a realidade do trabalho no campo. Justifica-se tal abordagem como antecedente do debate a respeito da maneira pela qual o ordenamento jurídico deve se amoldar, e vem tentando fazê-lo, às condições peculiares de relações trabalhistas no campo, especialmente as de curta duração, e quais os limites dessa maleabilidade.

Muito se tem escrito sobre a chamada crise do Direito do Trabalho, carente de efetividade e incapaz de estender à grande maioria dos trabalhadores a proteção que oferece aos empregados devidamente formalizados ${ }^{38}$. Não é tarefa do presente trabalho esmiuçar o tema, entretanto, é necessário apontar sua existência, apresentar algumas de suas características.

O ordenamento jurídico, destinado a regular relações sociais, deve estar sempre atento à evolução histórica e social da humanidade. Necessita o ramo juslaboral, assim, observar o desenvolvimento da economia, pois com esta guarda vínculos estreitos ${ }^{39}$, já que, como bem observa Pinho Pedreira ${ }^{40}$, ambos se debruçam sobre o mesmo fenômeno, "a atividade do homem que presta serviços".

\footnotetext{
${ }^{37}$ Faz-se coro com Sérgio Pinto Martins: "O Direito deve ser instrumento e não fim. É como instrumento da sociedade que o Direito deixa de ser um fim para ser um meio, devendo passar a prever soluções jurídicas para regular a informalidade.". MARTINS, Sérgio Pinto. A economia informal e o direito do trabalho. Revista do Tribunal Regional do Trabalho da 8a Região, Belém, v. 29, n. 57, p. 104, jul./dez. 1996.

${ }^{38} \mathrm{O}$ tema desperta interesse não apenas aos juslaboralistas, mas também aos que se dedicam a outros ramos do direito, bem como economistas e sociólogos. Cita-se, a título de exemplo: FARIA, José Eduardo Campos de Oliveira. A crise do direito do trabalho no Brasil. Revista da Faculdade de Direito da Universidade de São Paulo, São Paulo, v. 80, p. 197-209, jan./dez. 1985. TARSO, Genro. Crise terminal do velho direito do trabalho. Revista do Tribunal Regional do Trabalho da $9^{a}$. Região, Curitiba, v. 21, n. 1, p. 49-53, jan./jul. 1996. SOARES FILHO, José. A crise do direito do trabalho em face da globalização. Revista LTr, São Paulo, ano 66, n. 10, p. 1168-1183, out. 2002. ZYLBERSTAJN, Hélio. Globalização e regulação do mercado de trabalho no Brasil. São Paulo: Fiesp/Ciesp/IRS, 2000.

${ }^{39}$ MARTINS, Sergio Pinto. Flexibilização das condições de trabalho. 4. ed. São Paulo: Atlas, 2009. p. 10.

${ }^{40}$ PEDREIRA, Pinho. O direito do trabalho na crise. Revista do Tribunal Regional do Trabalho da $8^{a}$ Região, Belém, v. 21, n. 40, p. 93, jan./jun. 1988. No mesmo sentido observa Murilo Oliveira: "Constata-se que as crises do Direito do Trabalho sempre estiveram correlacionadas com os momentos de crise econômica.". OLIVEIRA, Murilo. Crise do direito do trabalho. LTr: revista legislação do trabalho, São Paulo, v 70, n. 8, p. 1000, ago. 2006.
} 
O caminhar histórico da economia e das relações de trabalho por ela proporcionadas vem se tornando cada vez mais dinâmico, com mudanças aceleradas e profundas, demandando do Direito do Trabalho alta capacidade de adaptação às novas realidades. O processo de globalização, catalisado pelo desenvolvimento das tecnologias da informação, a partir da segunda metade do século XX, acelerou de tal monta a evolução das relações de trabalho, que o Direito Laboral sofreu, e vem sofrendo, dificuldades para se manter próximo ao cotidiano dos atores sociais. O instrumental normativo é surpreendido pelo aumento do teletrabalho e de tantas outras modalidades inovadoras do prestar serviços.

As transformações e seus impactos no mundo do trabalho foram bem resumidos por Nelson Mannrich ${ }^{41}$ :

\begin{abstract}
"Observamos no cenário mundial grandes transformações. Fenômenos como o espetacular avanço da tecnologia e a internacionalização de mercados desenham uma nova configuração para o planeta. A revolução tecnológica, resultante em especial do desenvolvimento da informática, da microeletrônica e da robótica, além de imprimir profundas alterações nos sistemas produtivos, tem sido responsável pelo acesso imediato à informação e encurtamento de distância entre os povos. A abertura dos mercados reclama melhor produtividade e excelência dos produtos, passando a assumir posição de destaque e revolução gerencial, necessária à obtenção de novos padrões de qualidade, além de melhor produtividade.".
\end{abstract}

Nesses tempos, em que o Direito do Trabalho é provocado mais intensamente à adaptação, exaltam-se os defensores da desregulamentação, sob o ideal neoliberal de diminuição do papel do Estado. $\mathrm{O}$ argumento segue na trilha de que as regras protetivas trabalhistas representam um peso desmedido sobre a necessária competitividade das empresas, ameaçando seu desenvolvimento e sobrevivência. O fardo representado pelos direitos trabalhistas é anunciado como lastro a ser dispensado, única saída para evitar o naufrágio das empresas e da economia em geral.

Por outro lado, reagem as vozes contrárias a tal ideia, defendendo a preservação de todos os direitos trabalhistas, a qualquer custo, alardeando a crueldade do capital e do sistema financeiro, inimigos da sadia qualidade de vida dos trabalhadores, de sua dignidade

\footnotetext{
${ }^{41}$ MANNRICH, Nelson. A modernização do contrato de trabalho. São Paulo: LTr. 1998. p. 226. Dentre os muitos estudos sobre o tema, pode ser citado: NASCIMENTO, Amauri Mascaro. Globalização e seus efeitos no contrato de trabalho. In: FREDIANI, Yone (Coord). Tendências do direito material e processual do trabalho. São Paulo: LTr, 2000. p. 326-333.
} 
e de seus direitos fundamentais. A crise seria não do direito do trabalho, mas do sistema capitalista.

Como se percebe, logo o debate se vê contaminado por radicalismos ideológicos e políticos. Enquanto uns defendem a inadequação do ordenamento jurídico e o afastamento total do Estado, por não estarem atentos às mudanças sociais, outros sustentam a inadequação das mudanças sociais, por não respeitarem os direitos, ou alguns direitos fundamentais, garantidos pelo ordenamento jurídico.

Independentemente da posição ideológica que se adote, o que fica evidente quando a evolução social não é acompanhada pela evolução legislativa é a crescente distância que se vai instalando entre as relações sociais e as normas jurídicas.

Têm-se, então, duas situações indesejadas: a primeira é a atuação dos atores sociais à revelia da previsão normativa, em outras palavras, o desprezo da sociedade em relação aos modelos jurídicos existentes ${ }^{42}$. Exemplifica-se com a terceirização, sem regulação apropriada no direito brasileiro, exceção feita ao trabalho temporário, mas mesmo assim tão largamente utilizada e já arraigada na economia contemporânea. A segunda situação é a existência paradoxal de um relativamente pequeno número de trabalhadores amplamente protegidos, os empregados devidamente registrados, ao mesmo tempo em que um grande contingente de trabalhadores informais carece da proteção do ordenamento jurídico trabalhista, excluídos também do sistema previdenciário.

Inegável, portanto, a crise do Direito do Trabalho, pois, destinado a regular a vida social, desta se distancia. Garante proteção para poucos e deixa de oferecer tutela para muitos. Sérgio Pinto Martins ${ }^{43}$ aponta a distância entre os empregados registrados "muito protegidos" e os trabalhadores informais, a quem restam "injustiça e abandono". A distância existe também entre os informais e aqueles que, embora não sejam empregados, têm reconhecida juridicamente a sua atividade laboral. Aos trabalhadores avulsos ou temporários, por exemplo, o ordenamento jurídico prevê um rol de direitos que garantem a sua dignidade. Aos que trabalham sem formalização alguma, o risco da afronta à dignidade é patente.

\footnotetext{
${ }^{42}$ Nas palavras de Sérgio Pinto Martins: “O distanciamento entre a realidade e o Direito traz como consequência o descumprimento habitual da norma e, com isso, perda da autoridade da ordem jurídica do Esteado que a impõe. $O$ que acontece é que as pessoas acabam por descumprir a norma, por irreal, por ignorar a realidade dos fatos.”. MARTINS, Sérgio Pinto. A economia informal e o direito do trabalho, cit., p. 105.

${ }^{43}$ Id. Ibid., p. 103.
} 
Entretanto, não se deve enxergar a crise como causa suficiente para o fim do Direito do Trabalho, a desregulamentação completa das relações laborais. Ao contrário, trata-se da mola propulsora para o seu desenvolvimento, sua evolução e aproximação da realidade, a partir da devida adaptação. A necessidade de adaptação não é novidade para o Direito do Trabalho. Ao contrário, marca-lhe o nascimento e toda sua história, como bem aponta Nelson Mannrich ${ }^{44}$.

Portanto, a necessidade de se adaptar à realidade não representa, por si só, risco à existência do Direito Laboral. Não é em função dela que se percebe a dificuldade atualmente enfrentada pelo ordenamento jurídico trabalhista. O que se passa é a aceleração das mudanças sociais, mais especificamente nas relações de produção econômica e de trabalho, impulsionadas pela velocidade do desenvolvimento tecnológico, carecendo o Direito do Trabalho de velocidade adequada para a devida adaptação. Nesse contexto, o contrato de trabalho e sua modernização, é ponto nevrálgico para oferecer ao Direito Trabalhista meios de ganhar frente em seu processo constante de adaptação.

Ponto a partir do qual se definem todas as regras aplicáveis à relação intersubjetiva, seja de emprego ou não, o contrato de trabalho, quando devidamente formalizado, garante ao trabalhador não apenas a definição dos direitos que passarão a integrar seu patrimônio jurídico, mas também a sua inserção no sistema previdenciário de proteção. Como visto acima, a relação de trabalho formalizada, ainda que não empregatícia, outorga ao trabalhador o reconhecimento jurídico da sua atividade laboral, o que, atrelado à proteção previdenciária, constitui motivo de dignificação da sua condição. Não formalizado, o contrato de trabalho relega o trabalhador à exclusão, indigna e sem direitos, a menos que recorra ao judiciário.

Nessa conjuntura, pertinente é a lição de Nelson Mannrich ${ }^{45}$ ao apontar a necessidade de se modernizar o contrato de trabalho, desde que preservados direitos inafastáveis, oferecendo alternativas para a tradicional relação de emprego por prazo indeterminado, já que as relações sociais demandam o reconhecimento de outras formas de relacionamento entre o detentor do capital e o trabalhador. Em outras palavras, as relações econômicas se desenvolvem a ponto de permitir aos atores sociais novas formas de

\footnotetext{
44“Como se reconhece, desde sua origem, o Direito do Trabalho nasceu sob o signo da flexibilização, obrigando-se a constantes adaptações, em razão das mudanças e do ajuste à realidade, sem perder seu particularismo, sua vocação protecionista, enquanto o capitalismo não perder a sua, representada pela busca desenfreada do lucro." MANNRICH, Nelson. op. cit., p. 226.

${ }^{45}$ Id. Ibid., p. 71.
} 
prestação de serviço. Deve o direito do trabalho se adaptar, trazendo para seu quadro normativo a percepção dessas novas formas, para que garanta, também nestas, o reconhecimento jurídico e o reequilíbrio entre as partes, com proteção ao hipossuficiente.

Essa necessidade de adaptação à evolução social, presente em todos os ramos do Direito, se mostra mais evidente no Direito do Trabalho, pois se determinado costume social demanda alguns anos para se modificar, a inovação tecnológica em máquinas e equipamentos é capaz de alterar todo um método de produção em tempo muito menor. Enquanto isso, o direito trabalhista, para se adaptar, demanda o tempo do legislador, submetido não apenas aos ritos legislativos, mas também às pressões dos setores econômicos e sociais e ao amadurecimento das novas ideias no seio da sociedade.

No Brasil, a cristalização do mais importante diploma normativo do Direito do Trabalho, a CLT, já era sentida há mais de quinze anos, como bem observou Amauri Mascaro Nascimento ${ }^{46}$ em 1995:

“A Consolidação das Leis do Trabalho completou 50 anos. Nem a nossa
casa, a nossa residência, resiste 50 anos sem pelo menos uma pintura. A
CLT atravessou todo esse tempo, teve alguns pouquíssimos remendos,
num ou noutro capítulo, mas ela, embora significando um marco notável
na história da legislação trabalhista brasileira, não tem mais condições de
dar respostas suficientes às aspirações da época, além de se achar atingida
inexoravelmente pela Constituição Federal de 1988, que revogou diversos
dispositivos da CLT, dessa mesma CLT que continua a ser reproduzida e
republicada como se nada tivesse acontecido. (...) Daí a necessidade
inadiável de modernização das leis trabalhistas, quando não por uma
questão de transformação das ideias, pelo menos para um casamento,
para um ajuste entre a CLT e a Constituição de 88 que, ao que se diz,
pode passar inclusive por revisões.".

Ainda hoje não se elaborou uma revisão profunda ou reforma da CLT, editando-se apenas leis esparsas sobre um ou outro ponto. Mesmo durante o governo Lula, esperança para a realização da chamada reforma trabalhista, não se alcançou sequer a reforma do sistema sindical $^{47}$. Inegável, portanto, a lentidão com que o Direito do Trabalho, no Brasil, se adapta às mudanças sociais.

Com relação a essa adaptabilidade, há que se observar, o Direito do Trabalho apresenta certa vantagem, pois permite, entre suas fontes, a participação dos atores sociais envolvidos, mediante negociação coletiva. No lugar do Estado, que necessariamente

\footnotetext{
${ }^{46}$ NASCIMENTO, Amauri Mascaro. Visão global do direito do trabalho rural no Brasil. Revista do Tribunal Regional do Trabalho da $15^{a}$ Região, n. esp., p. 59, 1995.

${ }^{47}$ ZYLBERSTAJN, Hélio. A reforma sindical de Lula. Revista de Direito do Trabalho, São Paulo, v. 31, n. 119 , p. 94-116, jul./set. 2005.
} 
guarda distância da relação laboral privada, os próprios sujeitos, primeiros conhecedores das suas necessidades, interesses e restrições, gozam de competência para criar normas, gerir as próprias relações.

A diferença de poder entre os sujeitos, um a depender exclusivamente da própria força de trabalho para sobreviver, outro explorando o capital que possui, é compensada, ou neutralizada, pela união dos trabalhadores e defesa coletiva dos interesses, mediante representação sindical. Além disso, garante-se um patamar mínimo de dignidade, reflexo de direitos indisponíveis, ligados, por exemplo, à saúde e segurança dos trabalhadores e remuneração mínima.

Entretanto, no Brasil, a adaptabilidade do Direito do Trabalho a partir da negociação coletiva sofre com a incoerência do modelo sindical vigente. Apesar da liberdade sindical declarada no artigo $8^{\circ}$, caput e inciso I, da Constituição da República, permanecem constitucionalmente previstas características próprias do corporativismo fascista, herança de Getúlio Vargas, como a unicidade sindical, a obrigatoriedade da representação por categorias e a compulsoriedade da contribuição sindical, o chamado imposto sindical. Ferido por essa contradição interna, o sistema sindical brasileiro se ressente, é de conhecimento público, de grave falta de representatividade e legitimidade, sendo baixos os índices de sindicalização em grande parte dos setores econômicos.

Nesse contexto, a intervenção estatal surge, por vezes, como o instrumento utilizado para promover a adaptação do Direito Laboral à evolução social, com a promulgação de novas normas. A criação do FGTS, em $1967^{48}$, a Lei n. ${ }^{\circ}$ 6.019/74, sobre trabalho temporário e a Lei n. ${ }^{\circ}$ 9.601/98, sobre contrato de trabalho por prazo determinado, são exemplos de inovações legislativas nesse sentido, as duas últimas, relativas justamente ao contrato de trabalho, prevendo novas possibilidades de contratação. A adaptação das normas trabalhistas, portanto, se dá muitas vezes não pela via negocial, mas pela elaboração estatal de novas normas, destinadas a reconhecer, permitir e regular, formas de prestação de serviço demandadas pela sociedade.

Por negociação coletiva ou mediante novos instrumentos legais, o Direito do Trabalho, quanto mais adaptado à realidade, mais se mostrará apto a prever entre seus

\footnotetext{
${ }^{48}$ Alice Monteiro de Barros aponta estar o FGTS inserido no primeiro momento histórico brasileiro de flexibilização: "Em 1967 foi introduzido no Brasil, ao lado da estabilidade, o regime do Fundo de Garantia do Tempo de Serviço (FGTS), exatamente no primeiro momento histórico da flexibilização, como imposição do chamado Direito do Trabalho da emergência." BARROS, Alice Monteiro de. Curso de direito do trabalho. 7. ed. São Paulo: LTr, 2011. p. 797.
} 
modelos contratuais os novos tipos de prestação laboral produzidos pela dinâmica econômica da sociedade. Assim, poderá de maneira mais efetiva proteger a dignidade dos diversos trabalhadores.

Questão inerente ao tema, de importância ímpar, diz respeito aos limites da adaptabilidade. Sérgio Pinto Martins ${ }^{49}$, em profundo estudo sobre flexibilização, considera incorreta a expressão flexibilização do direito do trabalho, preferindo empregar flexibilização das condições de trabalho. Em suas palavras ${ }^{50}$ : “o certo não seria falar em flexibilização do Direito do Trabalho, mas em flexibilização das condições de trabalho, pois são estas que serão flexibilizadas."

Apesar de a prática ter consagrado a expressão flexibilização ${ }^{51}$, o mais adequado seria a expressão adaptabilidade, ou capacidade de acomodação, na visão do autor ${ }^{52}$ : "as expressões adaptabilidade e capacidade de acomodação significam o ajustamento das regras trabalhistas à realidade dos dias atuais.”.

Justifica-se, assim, a utilização da expressão adaptabilidade do direito, evitando-se a palavra já desgastada "flexibilização" e, consequentemente, a carga ideológica que pesa sobre ela, tão alardeada como causa de todos os males trabalhistas, por uns, ou como sua cura, por outros.

A questão dos limites à adaptabilidade do Direito do Trabalho não se afasta de seus aspectos históricos. O Direito do Trabalho possui, desde o seu surgimento, na esteira da chamada questão social eclodida após a Revolução Industrial, inegável caráter de proteção ao trabalhador, sob a luz da solidariedade, como bem salienta Alice Monteiro de Barros ${ }^{53}$.

\footnotetext{
${ }^{49}$ MARTINS, Sergio Pinto. Flexibilização das condições de trabalho, cit.

${ }^{50}$ Id. Ibid., p. 10.

${ }^{51}$ Sérgio Pinto Martins acaba por aceitar a utilização do termo: "Irei adotar a palavra flexibilidade ou o neologismo flexibilização para tratar do tema, em razão de a prática assim consagrar tais expressões.”. Id. Ibid., p. 10.

${ }^{52}$ Id. Ibid., p. 9.

53 “Lembre-se, entretanto, que, não obstante essa vinculação estreita com a economia, o Direito do Trabalho é motivado, essencialmente, por objetivos de ordem político-social, que visam corrigir as diferenças, elevando o nível social da classe trabalhadora, como imposição de solidariedade, que nos torna responsáveis pela carência dos demais.”. BARROS, Alice Monteiro de. op. cit., p. 70. No mesmo sentido, Vólia Bonfim Cassar resume em poucas palavras a inovação representada pelo surgimento do Direito do Trabalho nos moldes atuais, logo após a Revolução Industrial: "Além desta publicização do direito privado, onde o Estado toma para si a gestão das principais regras até então delegadas ao arbítrio dos particulares, o Direito do Trabalho implantou no Direito um sentimento de justiça, já que buscou compensar a parte economicamente mais fraca da relação jurídica, travada entre empregado $e$ empregador, de caráter eminentemente privado, mediante regulação legal, acarretando uma revisão dos pressupostos que informavam a ordem liberal, conferindo a ela um viés igualitário por meio da publicização da esfera privada.” CASSAR, Vólia Bonfim. op. cit., p. 14-15.
} 
Relaciona-se, assim, o Direito do Trabalho, com a realização da justiça social, valorizando a liberdade do ser humano. Nesse sentido aponta Amauri Mascaro Nascimento ${ }^{54}$ :

"O direito do trabalho tende à realização de um valor: a justiça social. não é o único meio de sua consecução, mas é uma das formas pelas quais um conjunto de medidas que envolvem técnicas econômicas de melhor distribuição de riquezas, técnicas políticas de organização da convivência dos homens e do Estado e técnicas jurídicas destinadas a garantir a liberdade do ser humano, dimensionando-a num sentido social, visa a atingir a justiça social."

Desse modo, considerando ser o Direito do Trabalho o instrumento eleito pelo Estado para promover o reequilíbrio de forças no confronto entre trabalho e capital, a questão dos limites da adaptabilidade trata de tentar indicar até que ponto a adaptação do Direito Laboral pode chegar sem se descaracterizar, sem perder de vista esse seu viés orientador. Ou seja, até que ponto suas normas podem ser interpretadas, alteradas, ou até mesmo revogadas, sem que se aniquile o seu cerne, aviltando direitos tidos como inafastáveis do trabalhador. Em outras palavras, significa buscar determinar em que medida a proteção ao trabalhador pode ser esmaecida em prol da economia, ou da saúde das empresas. O tema carrega consigo a inegável ideia de que a saúde das empresas é fundamental para a sobrevivência do próprio Direito do Trabalho, pois sem elas não há postos de trabalho, não há emprego.

Para aqueles que se deixam levar por radicalismos, a barreira da qual não se poderia passar estaria, de um lado, no mesmo lugar em que estão todos os direitos já conquistados, legalmente previstos, impedindo-se qualquer avanço; de outro lado, tal barreira poderia ser alocada tão distante quanto a própria inexistência de normas trabalhistas, permitindo-se a total desregulamentação. A dificuldade reside, para aqueles que não se extremam, na definição do local, entre uma posição e outra, onde deve ser colocada a barreira. Mais que isso, admitindo-se certa maleabilidade, certa possibilidade de se deslocar a barreira, o que é necessário pelas variações materiais de cada caso concreto, a dificuldade se dá na elaboração ou identificação de critérios seguros, estáveis, para se determinar tal margem de deslocamento. Sobre a necessidade de se evitar abusos na imprescindível adaptação do direito do trabalho, Vólia Bonfim Cassar afirma ${ }^{55}$ :

\footnotetext{
${ }^{54}$ NASCIMENTO, Amauri Mascaro. Curso de direito do trabalho. 26. ed. São Paulo: Saraiva, 2011. p. 60.

${ }^{55}$ CASSAR, Vólia Bonfim. op. cit., p. 21.
} 
"Não se discute que o processo de globalização vem de fato modificando as relações de trabalho, fazendo com que seja necessária uma revisão do Direito do Trabalho. Mas isto não quer dizer sua total desregulamentação.

A solução ao confronto travado entre a necessidade de se manter um Estado social de direito e a crise econômica das empresas, a flexibilização se mostra como melhor meio de composição deste conflito, mas de forma responsável e sem abuso."

O primeiro critério a ser defendido pela doutrina é o relativo às normas de ordem pública. Estas não poderiam ser afastadas, sob hipótese alguma. Nesse contexto, Sérgio Pinto Martins ${ }^{56}$ identifica, entre as classificações possíveis, a que divide os limites em dois tipos, os estabelecidos em normas de ordem pública e os relacionados à política econômica do governo, conforme artigo 623 da CLT. Fala também o autor ${ }^{57}$ em limites constitucionais e legais, apontando casos específicos em que a Constituição da República, ou a CLT, vedam a "flexibilização". Evidentemente, os limites constitucionais se aplicam, inclusive, ao próprio legislador, pelo dever de respeito à Constituição que todas as normas infraconstitucionais devem guardar. As regras constitucionais são o limite natural às adaptações promovidas pelas vias legislativa e negocial ${ }^{58}$, submetidas sempre ao controle de constitucionalidade.

Buscando alicerce nos direitos humanos, o que fica isento de dúvidas é a necessidade de se respeitar alguns direitos dos trabalhadores, sobre os quais a adaptação não pode avançar, ainda que os próprios obreiros assim desejem ou aceitem. Trata-se da proteção a vida, saúde, segurança, elementos que compõem, enfim, a dignidade da pessoa humana, a ser preservada inclusive no seu papel social de trabalhador ${ }^{59}$.

O respeito à dignidade, prolatada pela Constituição da República como fundamento da República (art. $1^{\circ}$, III) e finalidade última da ordem econômica e financeira (art. 170, caput), estará sempre a limitar as adaptações do direito laboral. Ao lado deste há outro limite, anterior, que se impõe antes do extremo da ameaça à dignidade do trabalhador.

\footnotetext{
${ }^{56}$ MARTINS, Sergio Pinto. op. cit., p. 129-130.

${ }^{57}$ Id. Ibid., p. 130 e ss.

${ }^{58}$ Concorda-se com Alice Monteiro de Barros, que afirma estar a negociação coletiva limitada pelos preceitos constitucionais: "Até nessa hipótese de flexibilização os limites mínimos previstos nos diplomas constitucionais e internacionais devem ser respeitados, mesmo porque os direitos trabalhistas integram o rol dos direitos fundamentais na Constituição de 1988.” BARROS, Alice Monteiro de. op. cit., p. 70.

${ }^{59}$ Nesse sentido, afirma Vólia Bomfim Cassar: "Flexibilizar pressupõe a manutenção da intervenção estatal nas relações trabalhistas estabelecendo as condições mínimas de trabalho, sem as quais não se pode conceber a vida do trabalhador com dignidade (mínimo existencial), mas autorizando, em determinados casos, exceções ou regras menos rígidas, de forma que possibilite a manutenção da empresa e dos empregos”. CASSAR, Vólia Bonfim. op. cit., p. 24.
} 
Trata-se da consideração do trabalho como valor social, erigido constitucionalmente, ao lado da dignidade da pessoa humana, a fundamento da República (art. $1^{\circ}$, inciso IV). A Constituição da República afirma a valorização do trabalho também ao se referir à ordem econômica e financeira (art. 170 caput) e à ordem social (art. 193 caput).

Tanto as adaptações autônomas (mediante negociação coletiva), quanto as heterônomas (impostas pelo Estado, pela elaboração de novas normas) devem, portanto, não apenas se afastarem da violação à dignidade do trabalhador, mas também prestigiar o trabalho enquanto valor social.

Respeitados os limites, urge aproximar o Direito do Trabalho das novas formas de produção e relações de trabalho na realidade já praticadas, para que sua vocação protetiva não permaneça restrita aos cada vez mais escassos postos de emprego por prazo indeterminado, mas seja ampliada a tantos trabalhadores quantos dela necessitem.

Nesse contexto, há que se afirmar o óbvio: urge aproximar o Direito do Trabalho também das antigas formas de produção e relações de trabalho. A dignidade da pessoa humana é o valor que deve, também, fundamentar a adaptação do Direito do Trabalho às atividades rurais de curta duração, prestadas pelos "boias-frias", ainda com altos índices de informalidade e de violação a direitos fundamentais.

Em outras palavras, a dignidade humana e o valor social do trabalho devem limitar não apenas o movimento do direito em busca da adaptação à realidade, mas também a sua paralisia, na medida em que esta pode provocar, ou ao menos deixar de evitar, afronta a direitos fundamentais.

\subsection{Trabalho rural e tutela jurídica}

Considerando o acima exposto, o trabalho rural se apresenta como um dos setores em que de maneira mais acentuada se percebe a necessidade de aproximação entre a tutela jurídica e a realidade.

"Não é possível tratar o trabalho rural sem sublinhar o grande desequilíbrio que houve na história normativa das relações de trabalho no Brasil.”. A afirmação é de Amauri Mascaro Nascimento ${ }^{60}$, referindo-se ao desequilíbrio entre o privilégio dado para a

\footnotetext{
${ }^{60}$ NASCIMENTO, Amauri Mascaro. Visão global do direito do trabalho rural no Brasil, cit., p. 59.
} 
elaboração estatal de normas trabalhistas, em detrimento da negociação coletiva. De fato, a preferência por normas heterônomas interferiu no processo histórico de formação brasileira do direito do trabalho, inclusive nas normas voltadas ao meio rural. Entretanto, a frase também se encaixaria perfeitamente para indicar a diferença histórica entre a tutela jurídica voltada ao trabalho urbano e a voltada ao trabalho rural no Brasil. Nesse sentido, Jorge Cavalcanti Boucinhas Filho ${ }^{61}$ constata inegável atraso da proteção jurídica ao rurícola, se comparada cronologicamente à tutela do trabalhador urbano.

A diferença constitui eco do processo inicial de formação do Direito do Trabalho, voltado primeiramente para as relações industriais de exploração da mão de obra ${ }^{62}$. É fluente na doutrina a indicação do surgimento do Direito do Trabalho, nos moldes atualmente conhecidos, a partir da Revolução Industrial ${ }^{63}$. Esta proporcionou certas condições materiais que fomentaram o início da intervenção estatal em prol dos trabalhadores das fábricas e indústrias. O liberalismo, defensor da igualdade meramente formal, produziu efeitos nefastos sobre as condições de trabalho do recém criado proletariado. Nos dizeres de José Martins Catharino ${ }^{64}$ : “Aquela 'liberdade', formal e não real, iria criar o campo propício, já no século XVIII, onde iriam ser lançadas as sementes do Direito do Trabalho".

De fato, a igualdade apenas formal, contrariada pela marcante desigualdade material, foi o pano de fundo para a exploração extrema da mão de obra, principalmente infantil $^{65}$ e feminina. $\mathrm{O}$ absurdo sofrimento imposto às crianças e adolescentes acabou por

61 "A história demonstra que, no Brasil, a proteção do rurícola sempre se verificou com bastante atraso, sobretudo quando comparamos cronologicamente o seu surgimento com o da tutela do trabalhador urbano." BOUCINHAS FILHO, Jorge Cavalcanti. Intervalos Intrajornada para o trabalho rural em exposição ao calor excessivo. Revista Síntese Trabalhista e Previdenciária, Brasília, v 23, n. 265, p. 83, jul. 2011.

${ }^{62}$ Sobre o surgimento do Direito do Trabalho, Amauri Mascaro Nascimento leciona: "O direito do trabalho surgiu como consequência da questão social que foi precedida pela Revolução Industrial do século XVIII e da reação humanista que se propôs a garantir ou preservar a dignidade do ser humano ocupado no trabalho das indústrias, que, com o desenvolvimento da ciência, deram nova fisionomia ao processo de produção de bens na Europa e em outros continentes.". NASCIMENTO, Amauri Mascaro. Curso de direito do trabalho, cit., p. 32.

${ }^{63}$ Pode ser citado, entre outros, Gustavo Filipe Barbosa Garcia: "Na realidade, o Direito do Trabalho surge com a sociedade industrial e o trabalho assalariado. (...) Nesse contexto, em razão das péssimas condições de trabalho, com excessivas jornadas e exploração do labor de mulheres e menores (a chamada 'questão social'), os trabalhadores começam a se reunir para reivindicar melhorias, inclusive salariais, por meio de sindicatos.”. GARCIA, Gustavo Filipe Barbosa. Curso de direito do trabalho. 5. ed. rev. atual. ampl. Rio de Janeiro: Forense, 2011. p. 38-39.

${ }^{64}$ CATHARINO, José Martins. Compêndio universitário de direito do trabalho. São Paulo: Editora Jurídica e Universitária, 1972. v. 1, p. 6.

${ }^{65}$ Amauri Mascaro Nascimento relata situações específicas de sofrimento infantil ao reproduzir entrevista em que se relata, entre outros fatos, o trabalho de duas crianças das três horas da manhã até as dez horas da noite, uma delas tendo sofrido acidente de trabalho, com a perda de um dedo. NASCIMENTO, Amauri Mascaro. Curso de direito do trabalho, 24 ed. cit., p. 17 e ss. 


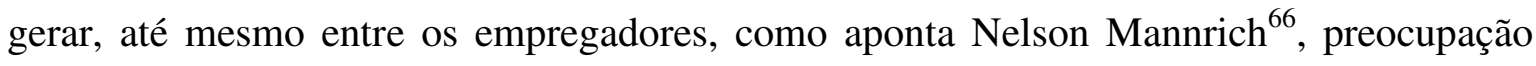
com a formação de mão de obra adulta saudável, já que se agigantava a quantidade de crianças e adolescentes doentes e subnutridos.

Fizeram-se presentes, também, condições de reunião e identificação entre os trabalhadores, sobre o que Amauri Mascaro Nascimento ${ }^{67}$ relata:

"Com a fábrica está correspondentemente formada a aglomeração maior das massas operárias. Ela não é só o local onde se assentar. É mais ainda: o ponto de convergência dessa mesma pluralidade de indivíduos, unidos por um mesmo processo de ideais, sujeitos a um mesmo ordenamento, subordinados a um mesmo homem, com as mesmas obrigações e os mesmos direitos.".

Tais precedentes jamais estiveram presentes no campo. As condições de trabalho no meio rural não se caracterizam pela concentração dos trabalhadores em um único local. $\mathrm{O}$ desenvolvimento tecnológico do século XIX produziu máquinas e equipamentos voltados para a produção industrial. Não há, outrossim, linha de produção e iluminação artificial na lavoura, a permitir exigência de trabalho ininterrupto por tanto tempo. Ademais, o isolamento dos locais de trabalho não torna tão evidente quanto no meio urbano as precárias condições dos trabalhadores.

Soma-se a tudo isso o caráter de novidade que a exploração industrial da força de trabalho representava, enquanto que a prestação de serviços rurais, acompanhando a história da humanidade, sempre se deu sem maiores proteções aos trabalhadores, em regime de escravidão ou de servidão. Assim, enquanto as péssimas condições de trabalho industrial representaram ineditismo alarmante, o sofrimento do trabalhador rural, também em precárias condições, não passava de circunstância há muito sedimentada entre os costumes socialmente aceitos.

Compreendem-se, assim, alguns dos motivos pelos quais o Direito do Trabalho surgiu primeiramente para os operários. As primeiras normas de proteção trabalhista se deram em prol dos trabalhadores urbanos, não dos rurícolas. A demonstrar esse fato,

\footnotetext{
${ }^{66} \mathrm{Nas}$ palavras do autor: "Até os empresários se preocupavam com o futuro da mão-de-obra, então constituída de crianças desnutridas e aniquiladas pelo trabalho prematuro.". A preocupação se deu, também com relação à dificuldade de se preparar exércitos nacionais. MANNRICH, Nelson. Inspeção do trabalho. São Paulo: LTr, 1991. p. 237.

${ }^{67}$ NASCIMENTO, Amauri Mascaro. Curso de direito do trabalho, 24 ed., cit., p. 15.
} 
conforme Amauri Mascaro Nascimento ${ }^{68}$, as primeiras intervenções estatais no sentido de regulamentar as relações de trabalho são passíveis da denominação "legislação industrial". A Lei de Peel, de 1802, da Inglaterra, dispondo sobre a limitação da jornada do menor nas fábricas e condições de educação higiene e dormitório ${ }^{69}$, é considerada um marco histórico do período do nascimento do Direito do Trabalho. Referia-se, como não poderia deixar de ser, ao trabalho junto às fábricas, urbano ${ }^{70}$.

Esse contexto histórico lançou seus efeitos sobre a Organização Internacional do Trabalho - OIT. Em 1995, durante o primeiro Congresso Brasileiro de Direito do Trabalho Rural, Amauri Mascaro Nascimento ${ }^{71}$ observou que menos de 5\% das Convenções da OIT tratavam do trabalho rural. Apesar de, em 1921, terem sido aprovadas duas Convenções relativas ao trabalho no campo (Convenção n. ${ }^{\circ} 11$ sobre sindicalização e Convenção n. ${ }^{\circ} 12$ sobre indenização por acidente de trabalho), a produção da OIT se voltou com maior peso para as relações urbanas de trabalho. A discrepância se evidencia quando são analisadas duas importantes Convenções sobre Inspeção do Trabalho. As normas relativas à Inspeção muito revelam a respeito do próprio direito do trabalho, pois, principalmente nos primeiros momentos históricos, ela representava condição imprescindível para a efetividade das normas trabalhistas. Segundo Manuel Alonso Olea ${ }^{72}$, a OIT afirma que "a legislação do trabalho, sem inspeção, é mais um exercício de ética que uma disciplina social obrigatória". Nesse sentido, se em 1947 a OIT aprovou a Convenção n. ${ }^{\circ}$ 81, relativa à Inspeção do Trabalho na Indústria e no Comércio, somente em 1969, mais de vinte anos depois, portanto, adotou a Convenção n. ${ }^{\circ}$ 129, relativa à Inspeção do Trabalho na Agricultura.

Importante registrar a observação de Nestor de Buen ${ }^{73}$, que identifica certas tendências da OIT quando esta se debruça sobre o tema. Cita o autor a preocupação não apenas com o trabalho assalariado, mas também com outras formas de trabalho, como arrendamento e parcerias, e a tendência a estender aos rurícolas os direitos dos

\footnotetext{
${ }^{68}$ Nas suas palavras: "A regulamentação jurídica do trabalho pelo Estado revestiu-se inicialmente de características às quais é dado o nome de legislação industrial.”. NASCIMENTO, Amauri Mascaro. Curso de direito do trabalho, 24 ed., cit., p. 55.

${ }^{69}$ Id. Ibid., p. 56.

${ }^{70}$ Interessante notar que no bojo da revolução industrial encontra-se um problema do meio rural, qual seja, a falta de trabalho no campo. Amauri Mascaro Nascimento aponta: "A mão de obra para a nova indústria procedia do campo. Na Inglaterra, desde o século XVI, havia desemprego rural, e a mobilidade do trabalhador, do campo para a cidade, foi estimulada pelos aparentes atrativos da indústria que se desenvolvia.". Id. Ibid., p. 37.

${ }^{71}$ Id. Visão global do direito do trabalho rural no Brasil, p. 60.

${ }^{72}$ ALONSO OLEA, Manuel; CASAS BAAMONDE, Maria Emilia. Derecho del trabajo. 18. ed., Madrid: Civitas, 2000. p. 1079.

${ }^{73}$ BUEN, Néstor de. La Organizacion Internacional del Trabajo (OIT) y el trabajo rural. Revista do Tribunal Regional do Trabalho da 15a Região, Campinas, n. esp. p. 78-88, 1995.
} 
trabalhadores urbanos. Algumas Convenções da OIT, apesar de não se dedicarem especificamente ao trabalho rural, sobre ele projetam seus efeitos, como, por exemplo, a Convenção n. ${ }^{\circ}$ 182, sobre as Piores Formas de Trabalho Infantil, aprovada no Brasil pelo Decreto Legislativo n. ${ }^{\circ}$ 178/99 e promulgada pelo Decreto n. ${ }^{\circ} 3.597 / 00$. Entre as atividades proibidas estão diversas relacionadas ao trabalho rural, como colheita de cítricos, processo produtivo de cana-de-açúcar, entre outros. Identifica-se, outrossim, a preocupação da OIT com a sindicalização no meio rural, adotando em 1975 a Convenção n. ${ }^{\circ} 141$ e a Recomendação n. ${ }^{\circ}$ 149, sobre organizações de trabalhadores rurais ${ }^{74}$.

A análise da relação entre trabalho rural e tutela jurídica não pode desprezar as precárias condições econômicas, sociais e culturais em que reconhecidamente vive a maioria dos trabalhadores rurais ${ }^{75}$. Faz-se coro com Amauri Mascaro Nascimento ${ }^{76}$, quando ele afirma não ser possível tratar do trabalho rural sem perceber sua relação com as políticas sociais do país, de saúde, de emprego, de previdência e agrária. A legislação trabalhista não teria o condão de, sozinha, promover profundas alterações nas relações laborais rurais, sendo necessárias mudanças políticas e econômicas. Entretanto, ao Direito e aos seus operadores não cabe o papel de assistir passivamente às reiteradas violações à dignidade dos trabalhadores rurais, aguardando a iniciativa política de se lhes dar a atenção devida. O Direito pode e deve interferir na realidade, auxiliando a sua transformação ${ }^{77}$. Nos dizeres de Sérgio Pinto Martins ${ }^{78}$ :

\footnotetext{
${ }^{74}$ EGGER, Philippe. Las organizaciones de trabajadores rurales y las condiciones de trabajo em la agricultura. Educacion Obrera, Ginebra, v.98, n. 1, p.4-8, 1995. Sobre as contradições do modelo sindical brasileiro: SANTOS, Ronaldo Lima dos. Sindicatos e ações coletivas: acesso à justiça coletiva e tutela dos interesses difusos, coletivos e individuais homogêneos. 2. ed. São Paulo: LTr. 2008.

${ }^{75}$ Trata-se de situação percebida não exclusivamente no Brasil, mas ao redor do mundo, como apontou Philippe Egger: "Hoy en día, estos trabajadores resultan ser todavía los menos sindicados en las organizaciones representativas de los trabajadores, continúan registrando los índices más altos de pobreza y tienen menos acceso a formas eficaces de protección social. Sigue siendo crucial el problema de estabelecer uma estratégia apropriada para reducir la pobreza y elevar nos niveles de sindicación y protección social.”. EGGER, Philippe. op. cit., p. 4.

${ }^{76}$ "Não é possível tratar o trabalho rural sem ver que está relacionado com os mais altos temas das políticas sociais do país: a política de saúde do país, a política de emprego do país, a política de previdência do país, a política agrária do país. Seria uma suposição totalmente ilusória a de que a legislação trabalhista éo fim, em si mesmo, e isoladamente está com todas as potencialidades suficientes para solucionar as grandes questões, inclusive as relações de trabalho no meio rural. Sem modificações nas grandes políticas do país, é inviável cogitar de um avanço, de um aperfeiçoamento nas relações de trabalho no meio rural. mesmo porque, no nosso desenvolvimento cultural, essas relações ainda são marcadas por um certo compasso de atraso em relação aos avanços que são verificados nas relações de trabalho dos meios urbanos.". NASCIMENTO, Amauri Mascaro. Visão global do direito do trabalho rural no Brasil, cit., p. 60.

${ }^{77}$ Segundo Philippe Egger, a estratégia para o progresso dos direitos e bem estar dos trabalhadores rurais deve estar fundada em três pilares defendidos pela OIT, o crescimento econômico, a negociação coletiva e um sistema adequado de proteção social, com normas trabalhistas fortalecidas. EGGER, Philippe. op. cit., p. 8.

${ }^{78}$ MARTINS, Sérgio Pinto. A economia informal e o direito do trabalho, cit., p. 95.
} 
"O Direito compõe a sociedade e nela nasce. Sofre influência dos fatores socioeconômicos, que vão certamente marcar o conteúdo das regras jurídicas, mas se destina à proteção de interesses. Interfere também o Direito nessa realidade, condicionando-a e transformando-a. A mudança social planejada está na esfera das realizações possíveis do Direito.”

Com tais considerações, passa-se a estudar como o ordenamento jurídico brasileiro voltou seus olhos para o trabalho rural.

\subsection{Trabalho rural e tutela jurídica no Brasil - dívida histórica}

No Brasil a evolução do ordenamento jurídico trabalhista também privilegiou o trabalhador urbano, preterindo o trabalhador rural. Desde o período anterior à proclamação da independência a situação do rurícola é marcada pelas precárias condições de dignidade. Segadas Vianna ${ }^{79}$ apresenta aspectos históricos revelando que os poucos trabalhadores rurais livres que conviviam com a escravatura, mesmo os pequenos proprietários, não desfrutavam de condições muito diferentes das dos escravos, exceção feita à senzala destes, em oposição a miseráveis choupanas daqueles.

A condição de vida dos trabalhadores livres da época se assemelhava à servidão, com extrema dependência do grande proprietário da terra, sua proteção e tolerância. Prestavam-lhe pequenos serviços e, ainda que uns poucos conseguissem se tornar pequenos sitiantes, permaneciam todos submissos ao latifundiário, em torno dele gravitando, a maioria na condição de meeiros ou agregados ${ }^{80}$.

Após a proclamação da independência e a abolição da escravatura, em 1888, o desenvolvimento da economia agrária do país marcou-se pelo descaso do poder político para com os inexperientes pequenos produtores, guerras tarifárias entre estados e municípios, falta de infraestrutura básica, como rede de transporte, e outros fatores que permitiram a Segadas Vianna ${ }^{81}$, afirmar, em 1963, a existência de crise permanente da agricultura e pecuária brasileiras.

\footnotetext{
${ }^{79}$ VIANNA, Segadas. O Estatuto do Trabalhador Rural e sua aplicação. Rio de Janeiro: Freitas Bastos, 1963. p. 23 e ss.

${ }^{80}$ Nas palavras de Segadas Vianna: “Assim, ao tempo da colônia, a situação, na vida rural, podia ser definida em três classes: a dos grandes latifundiários; a dos escravos, e a dos agregados juridicamente livres, mas sociavelmente na condição de servos.” Id. Ibid., p. 24.

${ }^{81}$ Id. Ibid., p. 30.
} 
Todo esse contexto, aliado à manutenção e ampliação do sistema de latifúndios ${ }^{82}$, acabaram por fomentar o êxodo rural, transformando a ambição do trabalhador rural que, no lugar de pretender ser proprietário de uma gleba para trabalhar, passou a almejar a melhoria das condições de vida no meio urbano ${ }^{83}$.

Logo após a abolição da escravatura veio a República, bafejada pelos princípios liberais de apreço pela liberdade contratual e não interferência do Estado nas relações privadas. É dessa época o Decreto 2.827 de 15 de março de 1893, dispondo sobre locação de serviços aplicada à agricultura. $\mathrm{O}$ diploma, que não pode ser considerado de proteção ao trabalhador, referia-se ao Código Comercial de 1850 como norma de aplicação subsidiária para as próprias omissões ${ }^{84}$.

Houve projetos de lei visando a regulamentação da locação de serviços na agricultura, mas não chegaram a ser aprovados. Um deles previa inclusive indenização no caso de despedida injusta. Entretanto, os ideais liberais serviram de fundamento para o veto, como se percebe no trecho a seguir transcrito ${ }^{85}$ :

"Intervir o Estado na formação dos contratos é restringir a liberdade e a
atividade industrial nas suas mais elevadas e constantes manifestações, é
limitar o exercício de todas as profissões garantidas em toda a sua
plenitude pelo art. $73, \S 24$ da Constituição. O papel do Estado, nos
regimes livres, é assistir como simples espectador à formação dos
contratos e só intervir para assegurar os efeitos e as consequiências dos
contratos livremente realizados."

Nos anos que se seguiram, início de 1900, alguns diplomas normativos foram promulgados, como o Decreto 979, de 6 de janeiro de 1903, sobre sindicalização rural, as leis 1.150 de 1904 e 1607 de 1906, ambas sobre a proteção ao salário dos trabalhadores agrícolas $^{86}$. Todas, segundo Segadas Vianna ${ }^{87}$, sem as mínimas condições de efetividade.

\footnotetext{
${ }^{82}$ José Carlos Evangelista de Araújo realiza importante estudo sobre a evolução da questão agrária brasileira, demonstrando o poder que sempre acompanhou os grandes proprietários de terras do Brasil. ARAÚJO, José Carlos Evangelista de. Modernização e conflito: os dilemas colocados pela questão agrária no Brasil. In: GIORDANI, Francisco Alberto da Motta Peixoto; MARTINS, Melchíades Rodrigues; VIDOTTI, Tarcio José (Coords.). Direito do trabalho rural: homenagem a Irany Ferrari. 2. ed. São Paulo. LTr, 2005. p. 23-64.

${ }^{83}$ Como afirma Segadas Vianna, no campo, o trabalhador (inclusive o pequeno proprietário) se percebia "abandonado de tudo e de todos" VIANNA, Segadas. op. cit., p. 31.

${ }^{84}$ Id. Ibid., p. 35.

${ }^{85}$ Trecho das razões de veto ao projeto de lei sobre locação agrícola, de 1899, extraído de: Id. Ibid., p. 36.

${ }^{86}$ Além de Segadas Vianna, Nilza Perez de Rezende também menciona tal evolução legislativa. REZENDE, Nilza Perez de. Obrigações trabalhistas do empregador rural. 4. ed. rev. atual. São Paulo: LTr. 1982. p. 11.

${ }^{87}$ VIANNA, Segadas. op. cit., p. 37. Nas palavras do autor: "a simples leitura do texto legal comprova a inutilidade de suas disposições. Num país onde analfabetos eram os 'operários agrícolas' e semianalfabetos, na sua maioria, os empregadores, era ilusória a garantia firmada em cadernetas agrícolas que só existiram, e em pequeno número, no Estado de São Paulo, onde a expedição das cadernetas foi fixada num decreto de 1913.”.
} 
Em 1916 o Código Civil trouxe algumas poucas disposições sobre o trabalho agrícola, merecendo destaque a proteção ao salário (artigos 1560 e 1567), inspirado nas leis referidas e no Decreto n. ${ }^{\circ} 6.437 / 07^{88}$. A lei civil, naturalmente baseada na igualdade formal entre as partes, não trouxe proteção ao trabalhador rural. Alice Monteiro de Barros $^{89}$ resume:

\begin{abstract}
"O desenvolvimento da agricultura e do pastoreio não despertou o mesmo interesse legislativo do que aquele manifestado em relação ao trabalho desenvolvido no meio urbano, embora nosso País seja de organização tradicionalmente agropecuária.
\end{abstract}

As relações de trabalho, anteriormente a 1943, eram disciplinadas por legislação esparsa e a partir de 1916 pelo Código Civil, que regulara a locação de serviços, a empreitada e a parceria rural.".

Quando Getúlio Vargas assumiu o poder, em 1930, cuidou de não contrariar a classe dos grandes latifundiários, dominante no país. Assim, apesar de anunciar a necessidade de proteger o trabalhador, pouco se voltou para o homem do campo ${ }^{90}$. O poderio dos latifundiários, dominante nas relações de trabalho desde os tempos de colônia, permaneceu inalterado $^{91}$. Apenas alguns diplomas foram promulgados, como o Decreto n. ${ }^{\circ}$ 24.637/34, sobre proteção ao trabalhador rural no caso de acidente do trabalho.

Em 1942, a comissão formada para consolidar a legislação trabalhista, entendeu por bem, conforme Segadas Vianna ${ }^{92}$, membro da comissão, dedicar ao trabalhador rural um código próprio. A CLT, assim, foi promulgada excluindo a aplicação dos seus preceitos ao trabalhador rural, salvo exceções expressas, como os artigos referentes ao salário mínimo (art. 76), férias remuneradas (art. 129, parágrafo único), aviso prévio (art. 505), normas gerais sobre contrato de trabalho e remuneração (art. 505 e 506).

A Constituição de 1946 trouxe maior preocupação com o meio rural, possuindo diversos dispositivos a ele voltados, como artigo 156 (fixação do homem no campo) e artigo 157, cujo inciso XX fazia menção expressa à estabilidade e indenização ao trabalhador rural. Entretanto, os direitos previstos constitucionalmente não foram

\footnotetext{
${ }^{88}$ VIANNA, Segadas. op. cit., p. 37-38.

${ }^{89}$ BARROS, Alice Monteiro de. Contratos e regulamentações especiais de trabalho: peculiaridades, aspectos controvertidos e tendências. São Paulo: LTr, 2001. p. 333.

${ }^{90}$ VIANNA, Segadas. op. cit., p. 37-38.

${ }^{91}$ DELGADO, Mauricio Godinho. Curso de direito do trabalho. 5. ed. São Paulo: LTr. 2006. p. 380.

${ }^{92}$ VIANNA, Segadas. op. cit., p. 38.
} 
considerados autoaplicáveis ${ }^{93}$, pouco se concretizando a proteção almejada. Da época, merece menção apenas a Lei n. ${ }^{\circ}$ 605/49, referente ao descanso semanal.

Em 1952 uma comissão composta por Alzira Vargas do Amaral Peixoto, Arnaldo Süssekind, Nerio Battendieri e Humberto Grande foi criada para apresentar estudos sobre a extensão aos rurícolas dos direitos já previstos para os trabalhadores urbanos. Dois projetos de lei foram apresentados, sobre proteção ao trabalhador agrícola e sobre contratos de parceria agrícola e animal $^{94}$. Uma das grandes preocupações da comissão era o êxodo rural e consequente inchaço dos centros urbanos, causados em grande parte pela diferença de tratamento jurídico, de proteção legal, entre os trabalhadores rurais e urbanos. O próprio desenvolvimento da industrialização restaria prejudicado pela disparidade de tratamento normativo 95 .

Interessante notar, no relatório da referida comissão, a identificação da necessidade de se observar as peculiaridades do trabalho rural, bem como a de buscar no próprio ambiente agrário o entendimento, a compreensão real dessa realidade campesina ${ }^{96}$, admitindo o abandono jurídico do trabalhador rural, sem garantias mínimas, e sofrendo de "alarmante pauperismo"97. Reconheceu-se a necessidade de "humanização" da parceria rural, então sob a égide do Código Civil.

Nesse contexto, foi aprovada a Lei n. ${ }^{\circ}$ 4.214, de 02 de março de 1963, o Estatuto do Trabalhador Rural e, a seguir, o Estatuto da Terra, Lei n. ${ }^{\circ}$ 4.504/65, trazendo disposições a respeito da reforma agrária e dos contratos de arrendamento e parceria rural. Nos dizeres de Nilza Peres de Resende, o Estatuto do Trabalhador Rural veio responder a uma "exigência da realidade social" 98 . A legislação teve o mérito de trazer, pela primeira vez no Brasil, o olhar do Direito para a relação de trabalho no campo, sendo considerada um

\footnotetext{
${ }^{93}$ DELGADO, Mauricio Godinho. op. cit., p. 380.

${ }^{94}$ VIANNA, Segadas. op. cit., p. 39.

${ }^{95}$ Id. Ibid., p. 39 e ss. Merece transcrição o seguinte trecho do relatório da comissão: "Ora, se o êxodo rural, com todos os prejuízos que vem acarretando, notadamente o enfraquecimento de nossa organização agrícola, encontra uma de suas causas na flagrante disparidade que se verifica entre os direitos conferidos aos trabalhadores da cidade e aos do campo, respectivamente, resulta inquestionável que se faz mister, em benefício mesmo do progresso de nossa industrialização, de um prudente nivelamento desses direitos, para que o fenômeno das migrações em massa do campo para a cidade encontre, através desse processo, a esperada e natural contenção.". Trecho extraído da obra VIANNA, Segadas. op. cit., p. 41.

${ }^{96}$ Id. Ibid., p. 43.

${ }^{97}$ Id. Ibid., p. 41.

${ }^{98}$ REZENDE, Nilza Perez de. op. cit., p. 12.
} 
divisor de águas99. A Lei n. ${ }^{9}$ 4.214/63 surgiu como uma espécie de "mini CLT" rural", tratando de maneira abrangente as relações de trabalho rural, com dispositivos sobre relações individuais e coletivas, direito processual e previdenciário.

Entretanto, não teve condições mínimas de efetividade, em função de diversos fatores, como a distância entre o trabalhador e o Poder Judiciário, a falta de condições da Inspeção do Trabalho ${ }^{101}$ de atuar de maneira firme nas relações do campo ${ }^{102}$ e as precárias condições dos próprios destinatários da norma, os trabalhadores rurais. Na grande maioria analfabetos, e até mesmo sem sentido de dignidade própria ${ }^{103}$, não tinham condições sequer de entender os próprios direitos ou reivindicá-los, ocupados que estavam em lutar contra a miséria ${ }^{104}$.

Diante de tal contexto, a Lei n. ${ }^{\circ}$ 4.214/63, não teve condições de atingir grandes níveis de aplicabilidade, tendo sido revogada dez anos mais tarde pela Lei n. ${ }^{\circ}$ 5.889/73, vigente até os dias de hoje. Amauri Mascaro Nascimento ${ }^{105}$ identifica de maneira precisa a diferença entre os dois diplomas normativos:

"O critério de 73 é oposto ao critério de 63. O de 63 é expressão do sistema brasileiro na amplitude na legislação; o critério de 73 é de uma legislação simples, reduzida, com poucos dispositivos (17 ou 18 artigos) contra os 183 de que era constituída a legislação de 10 anos atrás.".

\footnotetext{
${ }^{99}$ Maurício Godinho Delgado afirma: “A situação do trabalhador rural no Direito do Trabalho brasileiro conhece duas grandes fases, distintas sob qualquer ponto de vista: antes e após o Estatuto do Trabalhador Rural, diploma oriundo no ano de 1963." DELGADO, Mauricio Godinho. op. cit., p. 379.

${ }^{100}$ Expressão de Amauri Mascaro Nascimento, ao abordar a lei de 1963 no Primeiro Congresso Brasileiro de Direito do Trabalho Rural. NASCIMENTO, Amauri Mascaro. Visão global do direito do trabalho rural no Brasil, cit., p. 61.

${ }^{101}$ Sobre aspectos históricos da Inspeção do Trabalho no Brasil: BIGNAMI, Renato. A inspeção do trabalho no Brasil: procedimentos especiais para a ação fiscal. São Paulo: LTr, 2007. p. 31-39. E MANNRICH, Nelson. Inspeção do trabalho, cit., p. 38-48.

${ }^{102}$ NASCIMENTO, Amauri Mascaro. Curso de direito do trabalho. 24. ed. rev. atual. e ampl. São Paulo: Saraiva. 2009. p. 739.

${ }^{103}$ Nas palavras de Segadas Vianna: "O homem - o objetivo mais importante da legislação de proteção ao trabalho rural e que deveria ser melhor cuidado, esse recebe a nova legislação sem estar preparado para isso. Não lhe deram o essencial, o básico, que é o sentido de sua dignidade humana e da dignidade do trabalho que executa. (...) Esse é o homem rural brasileiro, na sua grande maioria; o 'Jeca Tatu', o "João Sem Nome', a quem deram uma legislação sem antes lhe ensinar as letras do alfabeto, sem prepará-lo fisicamente para a vida que raramente passa dos quarenta anos; sem lhe dar um mínimo de conhecimento que o tire dessa condição de subgente para lhe dar a condição humana a que tem direito e para que possa usar desses direitos que lhe outorgaram e que por muito tempo desconhecerá; que por muito tempo não poderá invocar com medo da violência que o patrão praticará, com o apoio e a ajuda do subdelegado de polícia, nomeado por indicação dos fazendeiros. Para preparar e dignificar esse homem nada se fez e nada se planeja ainda.". VIANNA, Segadas. op. cit., p. 60-62.

${ }^{104}$ Id. Ibid., p. 62-67. O autor relata péssimas condições de moradia, alimentação e o interesse dos proprietários de terras pela manutenção dos baixos índices de escolaridade dos trabalhadores rurais.

${ }^{105}$ NASCIMENTO, Amauri Mascaro. Visão global do direito do trabalho rural no Brasil, cit., p. 61.
} 
De fato, a Lei n. ${ }^{\circ} 5.889 / 73$, com seus poucos artigos, deixou para a aplicação subsidiária da $\mathrm{CLT}^{106}$ um número bem maior questões se comparada com o antigo Estatuto do Trabalhador Rural ${ }^{107}$. O atual regulamento da Lei n. ${ }^{\circ}$ 5.889/73, chamado Regulamento das Relações Individuais e Coletivas de Trabalho Rural, aprovado pelo Decreto n. ${ }^{\circ}$ 73.626/74, dedica seu artigo $4^{\circ}$ a explicitar quais artigos da CLT e legislação esparsa se aplicam às relações de trabalho rural. Amauri Mascaro Nascimento ${ }^{108}$ identifica uma tendência, consagrada posteriormente com a Constituição da República de 1988, de não se estabelecer para o trabalhador rural um corpo normativo próprio e diferenciado, mas de aproximar dele a legislação do trabalhador urbano, reservando-se pequenas diferenciações, aptas a lidar com as peculiaridades do campo. O artigo $7^{\circ}$ da Constituição da República equiparou os direitos na esfera individual, e o artigo $8^{\circ}$, parágrafo único, na esfera coletiva.

Assim, a partir de 1988 o trabalhador rural passou a ter para si ampla previsão de direitos $^{109}$. Na prática, entretanto, a intenção constitucional vem se concretizando de maneira lenta e difícil. Em muito permanece válida a descrição de Segadas Vianna a respeito das condições do trabalhador rural, manchando a imagem do país as diversas denúncias de trabalho análogo ao de escravo no meio rural.

A Constituição da República de 1988 previu para os trabalhadores rurais os mesmos direitos dos trabalhadores urbanos, representando grande avanço na proteção jurídica daqueles. Amauri Mascaro Nascimento exalta a importância da Constituição ${ }^{110}$, chamando a atenção não apenas para a unificação dos direitos (dos trabalhadores urbanos e rurais), mas também para o conceito de função social da propriedade rural $^{111}$. No seu

\footnotetext{
${ }^{106}$ Lei n. ${ }^{\circ} 5.889 / 73$, Art. $1^{\text {o: }}$ "As relações de trabalho rural serão reguladas por esta Lei e, no que com ela não colidirem, pelas normas da Consolidação das Leis do Trabalho, aprovada pelo Decreto-lei 5.452 de $1^{\circ}$ de maio de 1943."

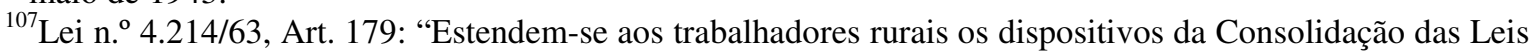
do Trabalho que não contradigam ou restrinjam o disposto nesta Lei.".

${ }^{108}$ NASCIMENTO, Amauri Mascaro. Visão global do direito do trabalho rural no Brasil, cit., p. 61.

${ }^{109}$ Entre eles, o direito fundamental ao trabalho digno. Quando a Constituição garante o direito ao trabalho se refere, ainda que implicitamente, ao trabalho digno. DELGADO, Gabriela Neves. Direito fundamental ao trabalho digno, cit.

110 “A Constituição de 1988 deu um passo que a coloca, como instrumento jurídico, em posição de vanguarda. É mais tutelar que as anteriores. São raríssimas as Constituições de outros países que asseguram proteção ao trabalhador rural maior do que a nossa que igualou os seus direitos aos do trabalhador urbano e que autoriza a desapropriação da propriedade rural se os direitos trabalhistas não estiverem sendo cumpridos." NASCIMENTO, Amauri Mascaro. O trabalho rural na Constituição de 1988: regulamentação e realidade. Revista LTr, São Paulo, ano 59, n. 10, p. 1309, out. 1995.

${ }^{111}$ Nas suas palavras: "Há dois pontos da maior importância. Primeiro, o conceito de função social da propriedade. Eleva, corretamente, o descumprimento das obrigações trabalhistas como um fator destipificante da função social da propriedade. Logo, permite a desapropriação, para fins de reforma agrária, de imóvel rural onde os direitos trabalhistas não são respeitados." NASCIMENTO, Amauri Mascaro. O trabalho rural na Constituição de 1988: regulamentação e realidade, cit., p. 1307.
} 
entender, o desrespeito às normas trabalhistas seria motivo para considerar também desrespeitada a função social da propriedade, o que autorizaria a sua desapropriação, com vistas à reforma agrária. Com esse entendimento, seria possível a desapropriação sem qualquer alteração no texto constitucional. Entretanto, faz-se necessário observar a Proposta de Emenda Constitucional n. ${ }^{\circ}$ 438, de 2001, segundo a qual serão confiscadas as terras onde for encontrado trabalho análogo ao de escravo, e destinadas à reforma agrária. A proposta foi aprovada pelo Senado Federal em 2003 e no ano seguinte pela Câmara dos Deputados, em primeiro turno. Ainda tramita no Congresso.

Com relação à extensão aos rurais dos direitos próprios dos trabalhadores urbanos, Amauri Mascaro Nascimento ${ }^{112}$ aponta o ganho, para os rurais, de dezenove "novos direitos individuais", conforme incisos do artigo $7^{\circ}$ da Constituição da República: 1) relação de emprego protegida contra despedida arbitrária ou sem justa causa e a indenização compensatória, com os $40 \%$ do FGTS; 2) seguro-desemprego; 3) pisos salariais; 4) irredutibilidade do salário, salvo negociação coletiva; 5) salário mínimo, mesmo para aqueles que recebem remuneração variável; 6) proteção do salário, criminalizando-se sua retenção dolosa; 7) participação nos lucros ou resultados e na gestão da empresa, conforme lei; 8) limite de 44 horas de trabalho semanal; 9) adicional de horas extras de, no mínimo, 50\%; 10) licença gestante de 120 dias; 11) licença-paternidade; 12) proteção ao mercado de trabalho da mulher, mediante incentivos específicos; 13) aviso prévio proporcional; 14) adicionais de insalubridade, periculosidade, e penosidade; 15) creches; 16) proteção em face da automação; 17) indenização de acidente de trabalho e auxílio acidentário; 18) isonomia salarial e 19) proibição de discriminações.

A Lei n. ${ }^{\circ}$ 5.889/73 foi recepcionada pela Constituição de 1988, permanecendo válidas as regras que, sem contrariar a Norma Magna, respeitam as especificidades do trabalho no campo ${ }^{113}$.

\footnotetext{
${ }^{112}$ NASCIMENTO, Amauri Mascaro. O trabalho rural na Constituição de 1988: regulamentação e realidade, cit., p. 1307.

${ }^{113}$ Nesse sentido, Marcelo Rodrigues Prata, em artigo destinado a tratar do parágrafo $5^{\circ}$ do art. $9^{\circ}$ da Lei n. ${ }^{\circ}$ 5.889/73, acrescentado pela Lei n. ${ }^{\circ}$ 9.300/96, afirma: "Antes de adentrarmos no tema, porém, é preciso se diga que a Carta Maior de 1988, art. $7^{\circ}$, caput, estendeu ao trabalhador rural os mesmos direitos concedidos ao urbano, sem, contudo, retirar-lhe os concedidos através da Lei Especial. Houve o fenômeno da recepção, ou seja, a atual Constituição novou o fundamento de validade da lei ordinária anterior, naquilo em que esta não confrontou com a primeira.”. PRATA, Marcelo Rodrigues. Inovações quanto ao contrato do trabalhador rural. Revista LTr, São Paulo, ano 61, n. 2, p. 171, fev. 1997.
} 
Desse modo, as normas e diferenciações sobre o repouso intrajornada ${ }^{114}$, serviços intermitentes $^{115}$, horário e adicional noturno ${ }^{116}$, descontos de moradia e alimentação ${ }^{117}$, aviso prévio $^{118}$ e escola primária ${ }^{119}$, permanecem válidas. Os dispositivos que, ao contrário, afrontam as regras constitucionais, não foram recepcionados, como o que previa a possibilidade de se remunerar menor de 16 anos com metade do salário mínimo ${ }^{120}$.

As diferenciações do direito do trabalho rural se justificam pelas peculiaridades da própria atividade rural, diversa em muitos aspectos da urbana. Francisco Pedro Jucá ${ }^{121}$, exemplifica as atividades de transporte de aves de corte, realizado necessariamente de madrugada, ou de pecuária de leite, com duas ordenhas, uma antes das cinco horas da manhã e outra ao anoitecer, para observar:

"Com isto pretendemos demonstrar que a unificação de jornada de trabalho, de composição remuneratória e de condições de trabalho não pode ser absoluta, sob pena de perder a eficácia, e converter o que pretende ser proteção em desproteção e até mesmo burla ou violação deliberada, com todo o rosário de consequiências sobejamente conhecidas."

Sobre as peculiaridades do trabalho rural, Marilda Izique Chebabi ${ }^{122}$ relata diversos termos conhecidos somente nesse ramo de atividade, como "bituqueiro"123", "coroamento ${ }^{124,}$, entre outros, demonstrando a real existência de um universo totalmente estranho a quem não está habituado com o cotidiano agrário. No mesmo sentido, Amauri Mascaro Nascimento ${ }^{125}$ defende que a Constituição da República garante apenas o mesmo "quadro básico" de direitos, não significando a unificação total de direitos entre trabalhadores urbanos e rurais. Algumas peculiaridades devem ser respeitadas, não tendo

\footnotetext{
${ }^{114}$ Art. $5^{\circ}$.

${ }^{115}$ Art. $6^{\circ}$.

${ }^{116}$ Art. $7^{\circ}$.

${ }^{117}$ Art. $9^{\circ}$.

${ }^{118}$ Art. $15^{\circ}$.

${ }^{119}$ Art. $16^{\circ}$

${ }^{120}$ Art. $11^{\circ}$.

${ }^{121}$ JUCÁ, Francisco Pedro. Disciplinamento do trabalho rural. In: CONGRESSO BRASILEIRO DE DIREITO DO TRABALHO, 4. 25-27 mar. 1996. Jornal do Congresso. São Paulo, LTr, 2008. p. 44.

${ }^{122}$ CHEBABI, Marilda Izique. Direito do trabalho rural. Revista do TRT da $15^{a}$ Região, n. 10, p. 195-207, 2000.

${ }^{123}$ Trabalhador que age em grupo, responsável pelo repasse no talhão, após a colheita da cana, recolhendo as "bitucas", ou seja, pedaços de cana mal cortada, ou deixados para trás pelas máquinas carregadeiras.

${ }^{124}$ Trabalho específico em volta das árvores frutíferas, eliminando mato e dificultando a perda de insumos aplicados.

${ }^{125}$ NASCIMENTO, Amauri Mascaro. Visão global do direito do trabalho rural no Brasil, cit., p. 61-62.
} 
havido a revogação da Lei n. ${ }^{\circ}$ 5.889/73 naquilo que ela dispõe sobre as especificidades do trabalho rural.

Havendo, portanto, entre o trabalho urbano e o rural, diferenças no plano fático, há que se prever diferenças também no tratamento jurídico ${ }^{126}$, em respeito ao princípio isonômico e como método de preservação do padrão mínimo de direitos, garantidor da dignidade dos trabalhadores rurais. Como será visto a seguir, o distanciamento do Direito do Trabalho das peculiaridades do campo permite perverso sistema informal de fornecimento de mão de obra, que não raro avilta a dignidade do trabalhador rural.

Assim, apesar da equiparação promovida pelo caput do artigo $7^{\circ}$ da Constituição da República representar inegável avanço, significando a afirmação jurídica de que ao trabalho rural deve ser dado e reconhecido o mesmo valor do trabalho urbano, a mera previsão constitucional não é suficiente para garantir ao trabalhador rural as mesmas condições de dignidade do trabalhador urbano.

\subsubsection{Inadequação do direito do trabalho para as atividades rurais de curta duração - afronta à dignidade do trabalhador}

Mostra-se insuficiente a mera previsão constitucional, apresentando o meio rural condições típicas que, não observadas devidamente pelo ordenamento jurídico, evidenciam a inadequação do arcabouço normativo, levando a situações em que a dignidade de muitos trabalhadores é violada. É dizer, há situações próprias do campo para as quais a legislação trabalhista ainda não encontrou resposta satisfatória. Trata-se dos trabalhadores contratados por curtos períodos, poucas semanas ou dias, que, pela inadequação do sistema normativo, acabam sem a formalização de contrato, excluídos da proteção trabalhista e previdenciária. Muitas vezes são arregimentados e pastoreados por intermediários sem condições financeiras de arcar com os custos trabalhistas, os chamados "gatos".

Marcelo Gonçalves Campos ${ }^{127}$, sobre o tema, observa a predominância no meio rural de contratos de curta ou curtíssima duração, cujas tarefas se encerram em semanas ou

\footnotetext{
${ }^{126}$ No mesmo sentido: MANTARAS, Luis Manuel. Las particularidades del trabajo agrario. Revista Argentina de Derecho Agrario y Comparado, Rosario, v. 2, n. 3, p. 77-88, dic. 1993.

${ }^{127}$ Nas palavras do autor: "Assim, visando ao cumprimento dos direitos, o legislador cria uma série de procedimentos que se aplicados ao trabalhador rural acabam por dificultar ou mesmo impedir a realização do direito. Como exemplo, tomemos a questão da assinatura da CTPS. No meio rural, salvo
} 
dias. O procedimento obrigatório de anotação em Carteira de Trabalho e Previdência Social (CTPS) acaba por se mostrar burocraticamente inadequado aos empregadores e indesejado pelos próprios trabalhadores, que evitam "sujar a carteira", ou seja, são receosos de que a anotação de contratos tão curtos na CTPS possa dificultar a obtenção de bons empregos no futuro.

Agrava-se a questão pela não incomum situação também precária dos pequenos produtores rurais, pessoas físicas que, contrariando a tradição latifundiária do país, resistem em propriedades menores, tentando competir no mercado com poucos pés de laranja, pequena produção de tomate, batata, cebola, entre outros. José Carlos Evangelista de Araújo ${ }^{128}$ analisa a evolução histórica da estrutura de ocupação e exploração agrícola no Brasil, apontando os diversos equívocos cometidos pela política agrária, tendente a fortalecer a concentração latifundiária e relegando o pequeno produtor rural à condição de sobrevivente. Transcreve-se trecho de suas conclusões:

\footnotetext{
"A luta de classes se acirra - por um lado na diversificação dos conflitos distributivos entre as facções que compõem o 'bloco histórico' hoje dominante no campo; de outro pela intensificação da exploração/exclusão de pequenos e médios produtores (sobretudo aqueles ainda submetidos a padrões 'tradicionais' de cultivo), posseiros e agregados, trabalhadores rurais e boias-frias.".
}

Percebe-se que, na visão do autor, os pequenos e até mesmo médios produtores rurais estão colocados na mesma condição dos trabalhadores rurais e bóias-frias, o que sinaliza a precária condição em que se encontram.

Geralmente, necessitam de mão de obra por curtos períodos, colhendo toda a produção em uma semana, ou menos. Exemplo de situação onde o serviço é necessariamente rápido é a colheita da batata. Após a retirada da rama, as batatas são removidas da terra por implemento agrícola tracionado por trator e imediatamente recolhidas pelos trabalhadores, pois a exposição ao sol escurece o produto, retirando-lhe valor comercial.

raras exceções ligadas à contratação de trabalhadores permanentes, predominam contratos de curta ou curtíssima duração. Muitas das vezes, tais contratos duram uma semana ou quando muito duas. Têm como característica a utilização de grande contingente de mão-de-obra por curtíssimos períodos de tempo. Realizar os procedimentos para a contratação e assinatura das CTPS para períodos tão curtos acaba por criar dificuldades burocráticas para os empregadores, além de que os próprios empregados, não raro, temem que suas Carteiras fiquem "sujas" e negam-se a apresentá-las para as devidas anotações". CAMPOS, Marcelo Gonçalves. Relações de trabalho rural e ilegalidade nas contratações: uma busca de soluções. Síntese Trabalhista, Porto Alegre, v. 12, n. 138, p. 9, dez. 2000.

${ }^{128}$ ARAÚJO, José Carlos Evangelista de. op. cit., p. 59. 
Em outras situações, a título de exemplo, o produtor rural dispõe de número razoável de pés de laranja, que demandariam trabalho por períodos mais longos, de dois ou três meses contínuos. Entretanto, dependente, por força contratual, da demanda da indústria compradora dos frutos, o produtor não consegue manter a mínima regularidade ou constância na tarefa de colheita, tendo de interromper o serviço após algumas semanas, retomando-o e logo após paralisando-o novamente, sem ritmo algum, conforme os pedidos da indústria, até o final da safra.

Nesses casos, mostra-se extremamente inadequada a legislação trabalhista. Não seria satisfatório responder à questão afirmando se tratar de trabalho eventual. A eventualidade não se dá exclusivamente pela quantidade de dias em que determinado trabalhador presta serviços ao empregador, mas leva em consideração, principalmente, a inserção das suas atividades na rotina do empregador, no seu núcleo produtivo. Eventual é o serviço esporádico, não previsto. A colheita dos produtos rurais, ao contrário, é a previsão mais aguardada pelo produtor rural, pois somente com seu êxito é que estará terminado o ciclo produtivo, podendo receber sua tão esperada receita. Não se pode, então, considerar como eventual o trabalhador rural que se ativa em tarefas não eventuais, mesmo sendo pequena quantidade de dias contratados ${ }^{129}$. José Martins Catharino ${ }^{130}$, a respeito da conceituação de trabalhador eventual, explica de maneira clara:

"Eventual significa casual, fortuito, que depende de acontecimento incerto. Mas, eventual em função de que e de quem ? Do trabalho prestado por determinado trabalhador, ou da atividade do empregador? (...)

Duas correntes principais existem quanto à caracterização da eventualidade. Na Itália predomina o critério da descontinuidade ou da falta de profissionalidade do trabalho prestado por determinado trabalhador. No México e no Brasil, segue-se o da natureza do trabalho em função da atividade da empresa. (...) Assim, a contrário senso, eventual é o trabalho do qual determinada empresa não necessita normal e permanentemente (de modo contínuo ou intermitente)."

\footnotetext{
${ }^{129}$ A apoiar o argumento, Alice Monteiro de Barros: "Também o 'bóia-fria' reúne, geralmente, os pressupostos do conceito de empregado, não podendo ser equiparado a um trabalhador eventual. Isto, porque, em regra, ele não executa serviços que dependam de um acontecimento incerto, mas tarefas necessárias ou essenciais à consecução da atividade normal do empregador, ainda que não sejam desenvolvidos em todos os dias da semana. Assim, na hipótese de o 'bóia-fria' participar de uma plantação ou colheita, ele não poderá ser considerado trabalhador eventual, pois essas tarefas estão inseridas no processo produtivo do empregador rural.”. BARROS, Alice Monteiro de. Contratos e regulamentações especiais de trabalho: peculiaridades, aspectos controvertidos e tendências, cit., p. 337.

${ }^{130}$ CATHARINO, José Martins. op. cit., v. 1, p. 185-186.
} 
Amauri Mascaro Nascimento ${ }^{131}$ aponta quatro teorias a respeito da diferença entre empregado e trabalhador eventual. A teoria do evento, segundo a qual o trabalhador é considerado eventual se for contratado para determinado acontecimento, evento. A teoria dos fins da empresa, que indica ser eventual apenas o trabalhador contratado para atividades diversas das relacionadas aos fins normais da empresa. A teoria da descontinuidade, considerando eventual aquele que, ao contrário do empregado, não se caracteriza pela permanência, trabalhando de maneira esporádica, ocasional. E a teoria da fixação jurídica na empresa, determinando ser eventual o trabalhador que não se fixa a uma fonte de trabalho. $\mathrm{O}$ autor ${ }^{132}$ elege esta última como a melhor teoria, exemplificando como eventual "o 'bóia-fria', volante rural, que cada dia vai trabalhar numa fazenda diferente, ganhando por dia, sem se fixar em nenhuma delas;". O autor critica a teoria dos fins da empresa exemplificando que, segundo ela, o "pedreiro que vai construir um muro de uma fábrica de automóveis não é empregado, mas trabalhador eventual." ${ }^{133}$. Seria equivocada a teoria, pois em tal situação o pedreiro pode ser, dependendo das circunstâncias, empregado.

Há que se observar o argumento do autor com ressalvas. A teoria dos fins da empresa não exclui a possibilidade de ser considerado empregado o trabalhador que se ativa em serviços diversos dos normais e rotineiros do empregador. Ou seja, no exemplo dado pelo autor, a teoria da finalidade da empresa prevê que o pedreiro pode ser considerado eventual, mas não exclui a possibilidade de ele ser, dependendo das circunstâncias, considerado empregado. A teoria apenas exclui a possibilidade de ser declarado eventual aquele que trabalha nas atividades normais da empresa.

A teoria da fixação jurídica na empresa se apresenta ajustada às situações em que a atividade empresarial é contínua e duradoura, sendo possível, então, comparar a não permanência do trabalhador com a constância da atividade econômica. Entretanto, no meio rural, naturalmente sazonal, a própria atividade produtiva é inconstante, não duradoura. Assim, muitas vezes a falta de fixação do trabalhador àquela única fonte de trabalho se dá não pela eventualidade do tipo de prestação laboral, mas porque a própria atividade daquele produtor dura pouco tempo. É o caso do pequeno produtor rural, cujos frutos são colhidos todos, por exemplo, em cinco dias. O trabalhador que permanece os cinco dias trabalhando nessa colheita não pode ser considerado "não fixo" à atividade econômica. Sua

\footnotetext{
${ }^{131}$ NASCIMENTO, Amauri Mascaro. Curso de direito do trabalho. 24. ed., cit., p. 856 e ss.

${ }^{132}$ Id. Ibid., p. 857.

${ }^{133}$ Id. Ibid., p. 858 .
} 
não permanência é condicionada pela característica peculiar da atividade de seu empregador.

Explica-se melhor o argumento a partir das observações feitas por Amauri Mascaro Nascimento ${ }^{134}$ :

"Trabalhador eventual é aquele que presta a sua atividade para alguém ocasionalmente. As características da relação jurídica que o vincula a terceiros podem ser assim resumidas: a) a descontinuidade, entendida como a não-permanência em uma organização de trabalho com ânimo definitivo; b) a impossibilidade de fixação jurídica a uma fonte de trabalho, conseqüiente dessa mesma descontinuidade e inconstância e da pluralidade de tomadores de serviços; c) a curta duração de cada trabalho prestado.".

Das três características descritas, a primeira se refere à não permanência em uma organização de trabalho com ânimo definitivo. O trabalhador rural a que o presente estudo se refere, como aquele contratado para a colheita em pequenas áreas, não se enquadra na hipótese. Não é ele que se vincula de maneira não permanente à organização produtiva, é esta que, por suas peculiaridades, não se dá de maneira duradoura. Entretanto, enquanto a atividade produtiva existiu, é dizer, durante os poucos dias em que a colheita durou, aquele trabalhador esteve permanentemente prestando serviços à mesma e única fonte de trabalho.

A segunda característica seria a impossibilidade de fixação jurídica, decorrente da descontinuidade, inconstância e pluralidade de tomadores de serviço. Mais uma vez, não se trata do caso em tela. A inconstância não é do trabalhador em relação ao seu empregador, mas da própria atividade deste. Ou seja, em um mês o trabalhador pode prestar serviços para diversos tomadores, vinculando-se a cada um deles enquanto durar cada colheita.

A terceira característica, relativa à curta duração dos serviços, merece também uma análise diferenciada. A duração da prestação de serviço deve ser mensurada a partir da atividade econômica a que se vincula. Se a atividade da colheita dura, por exemplo, dez dias, o trabalhador que a ela se vinculou pelos dez dias não o fez por curto período, mas pelo período todo em que houve atividade.

Após tais explicações se percebe que a teoria da fixação jurídica na empresa, satisfatória para os casos em que a atividade empresarial é duradoura e contínua, deve ser entendida com ressalvas no meio rural, em que, muitas vezes, é a própria organização produtiva que se caracteriza por atividades intermitentes. Defende-se, então, não a adoção

\footnotetext{
${ }^{134}$ NASCIMENTO, Amauri Mascaro. Curso de direito do trabalho. 24. ed., cit., p. 858.
} 
de uma única teoria, mas a conjugação dos diversos critérios a respeito do trabalho eventual. A teoria da finalidade da empresa não pode ser completamente desprezada, pois goza do apreço da jurisprudência, tendo sido prestigiada pela Súmula n. ${ }^{\text {o }} 331$ do TST, ao tratar da terceirização.

Não se ignora a situação em que o trabalhador, mesmo antes de terminar a pequena colheita do produtor rural que o contratou, presta serviço para outros tomadores, podendo se falar, neste caso específico, de falta de fixação jurídica a uma única organização produtiva. Trata-se, entretanto, de exceção. Ou é fraude do trabalhador, que devidamente registrado, falta ao serviço atrás de remuneração imediata maior, onde a informalidade permite; ou é a única alternativa do trabalhador não registrado que, não recebendo a devida remuneração pelo dia parado em virtude de condições climáticas, deixa-se arregimentar pelo intermediário, chamado "gato", para prestar serviço também informal a outras fazendas, conseguindo, assim, não "perder o dia". Como se percebe, são situações à margem da legalidade, que não podem servir como fundamento para a definição do trabalho eventual.

Também à margem da lei é o caso exemplificado pelo autor ${ }^{135}$, em que determinado obreiro trabalha cada dia para um produtor rural diferente, recebendo por dia, sem se fixar em nenhuma propriedade. Há que se analisar tal caso com prudência. Não há condições materiais para que o trabalhador rural aja dessa maneira sozinho, apresentando-se livre e espontaneamente, cada dia, em uma propriedade rural diferente, sem saber previamente se seus serviços seriam ali necessários, deslocando-se por grandes distâncias sem a certeza do serviço. Por outro lado, o produtor rural não deixaria nas mãos do acaso a necessidade de mão de obra para a colheita de seus produtos, esperando aparecer, a cada dia, na porta (ou porteira) de sua propriedade, o número suficiente de trabalhadores volantes. Não é assim que acontece.

O trabalhador rural não se transfere a cada dia, de uma propriedade para outra, sem ser transportado por alguém, muitas vezes em precários meios de transporte. Há todo um sistema de contratação, elaborado à revelia do ordenamento jurídico, em que o intermediário, chamado "turmeiro" ou "gato", mediante as diversas solicitações dos produtores rurais, fornece mão de obra sem qualquer possibilidade de o trabalhador exercer o mínimo poder de decisão de onde ou para quem irá trabalhar.

\footnotetext{
${ }^{135}$ NASCIMENTO, Amauri Mascaro. Curso de direito do trabalho. 24. ed., cit., p. 857.
} 
Como se percebe, o rurícola que a cada dia trabalha para um produtor rural diferente, sendo remunerado por dia, sem se fixar perante nenhum deles, representa antes um esquema de fornecimento ilegal de mão de obra do que de trabalho eventual propriamente dito.

Ocorre que, em função dos altos encargos tributários, dos altos custos do vínculo empregatício, da grande burocracia e da falta de estrutura administrativa e econômica dos pequenos produtores rurais, o modelo jurídico próprio para contratação de mão de obra rural para curtos períodos, como o contrato de safra, se apresenta incompatível com a realidade.

Nesse contexto, declarar o trabalho rural de curta duração como eventual se torna a opção mais fácil para evitar enxergar o real problema, que é a inadequação do Direito do Trabalho para lidar com a situação fática. Sob o ponto de vista do tomador dos serviços, em que pese sua inegável participação no sistema já arraigado culturalmente de fornecimento ilegal de mão de obra, é juridicamente questionável considerar empregado aquele trabalhador que se ativou por um único dia em sua propriedade. De fato, esse sistema de fornecimento ilícito de mão de obra gera situações em que na mesma propriedade os trabalhadores são ou podem ser substituídos todos os dias, sendo difícil de se verificar o elemento pessoalidade, o "intuito personae" caracterizador da relação de emprego.

Entretanto, sob o ponto de vista do trabalhador, o rótulo de eventual o mantém inescrupulosamente condenado à exclusão da proteção trabalhista e previdenciária. Apesar de a legislação previdenciária equiparar o trabalhador eventual ao autônomo136, na prática, os rurícolas volantes não possuem condições materiais de se inscreverem no sistema previsto pelas Leis 8.212 e 8.213 de 1991. Ou seja, se a declaração de vínculo empregatício não é a melhor solução, também não o é a afirmação de que se trata de trabalhador eventual.

O trabalho eventual, apesar de estar previsto na legislação previdenciária, (art. 12, inciso V, alínea “g” da Lei n. ${ }^{\circ} 8212 / 91$ ), é figura jurídica a que nenhum direito trabalhista foi concedido. Amauri Mascaro Nascimento ${ }^{137}$ é inequívoco: “A CLT é inaplicável ao trabalhador eventual. Seus direitos são contratuais.”.

Em outras palavras, o trabalhador rural, hodiernamente mais vulnerável que o urbano, quando considerado eventual é transportado para os tempos da revolução industrial, em que às relações de trabalho se aplicavam apenas as regras estabelecidas nos

\footnotetext{
${ }^{136}$ NASCIMENTO, Amauri Mascaro. Curso de direito do trabalho. 24. ed., cit., p. 859.

${ }^{137}$ Id. Ibid., p. 860.
} 
contratos, nenhuma proteção legal. A afronta à dignidade é evidente. Percebe-se, outrossim, a inadequação do ordenamento jurídico, que não consegue apresentar solução satisfatória para o caso ${ }^{138}$.

Defende-se a extensão aos trabalhadores eventuais de determinados direitos trabalhistas, desde que compatíveis, como bem pontua Amauri Mascaro Nascimento ${ }^{139}$.

A previsão normativa mais próxima da prestação de serviço de curta duração, em tarefas não eventuais, como plantio ou colheita em pequenas áreas, seria o contrato de trabalho por prazo determinado, especificamente o contrato de safra, próprio do meio rural. No entanto, carece o pequeno produtor rural de estrutura administrativa ${ }^{140}$ para atender à burocracia necessária. Ademais, os custos, principalmente os necessários em função das normas de segurança e saúde, se apresentam demasiados e desproporcionais ${ }^{141}$ ao período do contrato.

A terceirização permanece vedada pela Súmula n. 331 do TST, já que a colheita é, sem dúvida, parte da atividade fim de quem produz bens rurais, condição imprescindível para a consecução dos fins econômicos ${ }^{142}$. Não se poderia utilizar, outrossim, o trabalho temporário, quer pela expressa vedação legal ${ }^{143}$, quer pela ausência dos pressupostos autorizadores da sua utilização ${ }^{144}$. A inadequação do ordenamento jurídico para a situação

\footnotetext{
${ }^{138}$ Nesse sentido, Paulo Guilherme de Almeida, comentando a lei n. ${ }^{\circ}$ 5.889/73: “Portanto, o impasse continua e provoca intranquilidade no meio empresarial agrícola. É quase unânime o entendimento de que a aplicação da legislação do trabalho rural, com tratamento inadequado e fora da realidade rural, criou um forte desestímulo à contratação da mão-de-obra permanente que, geralmente, implica na saudável permanência e residência do trabalhador na própria sede da fazenda. Com tal medida, o legislador provocou a dispensa do trabalhador permanente, fazendo aumentar o contingente de mão-de-obra marginalizada. Mas a situação é bem mais complexa do que se pode imaginar. O fato ocasionou um fenômeno perverso: o próprio empregado volante, em proporção considerável, não quer mais ser contratado pelo empresário, nos moldes dos contratos tradicionais e permanentes, pois consegue diárias proporcionalmente mais substanciosas, trabalhando três ou quatro dias por semana, do que se trabalhasse para receber por mês." ALMEIDA, Paulo Guilherme de. Aspectos negativos da legislação trabalhista rural. LTr: suplemento trabalhista, São Paulo, ano 13, n. 87, p. 394, 1987.

${ }^{139}$ Nas suas palavras: "A necessidade de extensão dos direitos trabalhistas ao eventual vem sendo sustentada pelos doutrinadores, por um imperativo de justiça social.”. Segundo o autor, a legislação argentina já prevê tal extensão, carecendo o direito pátrio de norma similar. NASCIMENTO, Amauri Mascaro. Curso de direito do trabalho. 24. ed., cit., p. 859.

${ }^{140} \mathrm{~A}$ menção à falta de estrutura administrativa mínima dos pequenos produtores rurais consta da exposição de motivos da Medida Provisória n. ${ }^{\circ}$ 410/07, como será visto adiante.

${ }^{141}$ Não se trata de mero fornecimento de Equipamento de Proteção Individual, mas todas as medidas de gestão e prevenção de riscos preconizadas pela Norma Regulamentadora n. ${ }^{\circ} 31$.

${ }^{142}$ Claudio Urenha Gomes entende, de maneira isolada, ser possível a terceirização na atividade fim no meio rural. GOMES, Claudio Urenha. Trabalho rural: a permissão da terceirização em atividade-fim. Revista LTr, São Paulo, v. 69, n. 11, p. 1375-1378, nov. 2005.

${ }^{143}$ Lei n. ${ }^{\circ}$ 6.019/74, Art. 4: "Compreende-se como empresa de trabalho temporário a pessoa física ou jurídica urbana, cuja atividade consiste em colocar à disposição de outras empresas, temporariamente, trabalhadores, devidamente qualificados, por elas remunerados e assistidos."

${ }^{144}$ Lei n. ${ }^{\circ}$ 6.019/74, Art. $2^{\text {o: }}$ "Trabalho temporário é aquele prestado por pessoa física a uma empresa, para atender à necessidade transitória de substituição de seu pessoal regular e permanente ou à acréscimo extraordinário de serviços.".
} 
concreta é patente, havendo, nas palavras de Amauri Mascaro Nascimento ${ }^{145}$, zonas cinzentas entre emprego, trabalho intermitente e trabalho eventual, carecendo-se de norma que regulasse a matéria.

Percebe-se a dificuldade de se encontrar alternativa legal plausível e financeiramente viável para a formalização da atividade laboral, ou, por outro ângulo, percebe-se a facilidade com que se veem empurrados tanto o empregador como o trabalhador para a informalidade, o que, se por um lado permite ao pequeno produtor rural menores custos, e ao trabalhador remuneração imediata maior, por outro lado expõe o produtor rural à insegurança jurídica, e condena o rurícola à exclusão total dos sistemas de proteção trabalhista e previdenciária, subordinando-o a situações em que lhe faltam não apenas remuneração mínima e FGTS, mas condições básicas de segurança e saúde, prevenção de acidentes e até mesmo água potável.

\subsubsection{A questão das cooperativas rurais de mão de obra}

A conhecida experiência desastrosa das cooperativas de mão de obra no campo teve como uma das causas a incapacidade do quadro normativo de absorver as relações de trabalho rural de curta ou curtíssima duração. À criatividade fraudulenta dos empregadores não pode ser atribuída toda a responsabilidade, pois, diante de tantas outras relações trabalhistas, não alcançaram as fraudes tamanha dimensão.

Sem um modelo jurídico viável, os agricultores e intermediadores passaram a enxergar na utilização das cooperativas, principalmente após a Lei n. ${ }^{\circ} 8.949$ de 9 de dezembro de 1994, uma alternativa para o enquadramento das relações de trabalho em um modelo jurídico, com redução dos custos trabalhistas a partir da eliminação de direitos. A referida lei incluiu o parágrafo único ao artigo 442 da CLT $^{146}$ : "qualquer que seja o ramo de atividade da cooperativa, não existe vínculo empregatício entre elas e seus associados, nem entre estes e os tomadores de serviço daquela.”.

\footnotetext{
${ }^{145}$ NASCIMENTO, Amauri Mascaro. Curso de direito do trabalho. 24. ed., cit., p. 862.

${ }^{146}$ A Lei foi originalmente defendida pelo Movimento dos Trabalhadores Sem Terra, preocupado com as relações de trabalho em seus assentamentos. MELO, Raimundo Simão de. Cooperativas de trabalho. Revista de Direito do Trabalho, São Paulo, v. 25, n. 95, p. 49, jul./set. 1996.
} 
A declaração expressa da inexistência de vínculo empregatício com o tomador dos serviços foi, na prática, interpretada de maneira deturpada, desvirtuando-se a figura da cooperativa $^{147}$.

Antes de se abordar o tema do cooperativismo, há que se relatar determinadas circunstâncias históricas presentes no interior do estado de São Paulo, descritas por Francisco José da Costa Alves e Luiz Fernando Paulillo ${ }^{148}$. Segundo os autores, na década de 80 a agroindústria, em processo de modernização e crescimento da capacidade de moagem, assumiu para si as tarefas rurais. Tanto a indústria sucro-alcooleira como a de suco concentrado de laranja passaram a adquirir a matéria prima, responsabilizando-se pela colheita. Na década seguinte, no entanto, o movimento se inverteu, a responsabilidade pelos serviços rurais foi devolvida aos fornecedores. Somou-se a isso a imposição, pela agroindústria, de um processo de seleção dos fornecedores a partir da maior produtividade por menores preços, forçando os produtores rurais a buscarem a redução desenfreada de custos. Os autores resumem o processo relatando o repasse das dificuldades econômicas da agroindústria para os produtores, e destes para os trabalhadores ${ }^{149}$.

Foi nesse contexto, portanto, que em 1994 houve a alteração legislativa, declarando a inexistência de vínculo empregatício entre os cooperados e o tomador dos serviços da cooperativa, o que foi recebido pelos produtores rurais, principalmente os de menor produção e, portanto, em maiores dificuldades, como solução para os altos custos da

\footnotetext{
${ }^{147}$ Pertinente é a observação de Henrique Damiano, a respeito da diferença entre o cooperativismo lícito e o desvirtuado ou deturpado: "Frente às disposições contidas no artigo $9^{\circ}$ da Consolidação das Leis do Trabalho (...), verificaremos que não é o instituto do cooperativismo que é perverso em si, mas a maneira como o homem o utiliza que o torna nefasto ou benéfico à sociedade. Visando o tomador dos serviços utilizar, unicamente, a cooperativa para com isso obter a redução de custos sem se preocupar com o aprimoramento da produção e com a realização adequada do trabalho, tal procedimento não condizirá com o escopo do cooperativismo. Ao contrário, se a atividade das cooperativas é sadia, observar-se-á o fenômeno do trabalho sendo concebido com absoluta dignidade e proporcionando, inclusive, a seus agentes melhores condições de vida do que as oferecidas pelos sistemas de trabalho tradicional.". DAMIANO, Henrique. Cooperativas de trabalho e consórcio de empregadores rurais. Revista do Tribunal Regional do Trabalho da 15ª Região, Campinas, n. 19, p. 176, jun. 2002.

${ }^{148}$ ALVES, Francisco José da Costa; PAULILLO, Luiz Fernando. Sindicato dos trabalhadores avulsos: a agricultura paulista sai na frente. Revista LTr, São Paulo, ano 63, n. 8. p. 1048-1055, ago. 1999.

149 "É necessário entender também que nos complexos agroindustriais estruturados, fundamentalmente cana e laranja, a prática predominante nos anos 90 foi a de transferência de custos para os agentes menos organizados e com menor poder de barganha no interior das cadeias. Neste processo o poder esteve sempre concentrado nos segmentos agroindustriais, que transferiram para os elos mais débeis as conseqüiências nefastas do processo de crescente internacionalização do capital, quer aqueles derivados de queda das exportações ou dos preços internacionais - no caso citrícola -, quer os derivados da crise de regulação do Estado no caso do complexo sucro-alcooleiro. Premidos pelas indústrias processadoras, os produtores repassaram aos trabalhadores as perdas adquiridas do relacionamento desequilibrado nos complexos agroindustriais”. ALVES, Francisco José da Costa; PAULILLO, Luiz Fernando. op. cit., p. 1051.
} 
contratação direta da mão de obra. As cooperativas, como não poderia deixar de ser, restaram desvirtuadas.

O cooperativismo, enaltecido pela Recomendação n. ${ }^{\circ} 127$ da OIT, de 1966 como meio para o progresso econômico e social dos países em desenvolvimento, e estimulado pelo artigo 174, $\S 2^{\circ}$ da Constituição da República Brasileira, possui características e requisitos incompatíveis com a mera intermediação de mão de obra visando redução de custos trabalhistas.

Baseada na união coordenada de esforços, visando um determinado objetivo em comum, a legítima cooperativa tem por escopo o benefício dos próprios cooperados, mediante a distribuição das sobras proporcionalmente ao trabalho de cada um dos sócios. A cada cooperado cabe a dupla função de executar e dirigir os serviços, não havendo subordinação perante o tomador.

$\mathrm{O}$ artigo $4^{\circ}$ da Lei $n .^{\circ} 5.764 / 71$ define cooperativa como a sociedade de pessoas constituída para prestar serviços aos associados. Conforme Raimundo Simão de Melo ${ }^{150}$, os requisitos de qualquer cooperativa, normalmente formada por trabalhadores tipicamente autônomos, são: 1) espontaneidade quanto à criação; 2) independência e autonomia dos cooperados; 3) objetivo comum que une os associados pela solidariedade; 4) autogestão; 5) liberdade de associação e desassociação; 6) não flutuação dos associados no quadro da cooperativa.

Maurício Godinho Delgado ${ }^{151}$ aponta dois princípios que devem estar sempre presentes nas atividades de qualquer cooperativa, o da dupla qualidade e o da retribuição pessoal diferenciada. Dupla qualidade significa que o cooperado deve ser, ao mesmo tempo, colaborador e cliente da cooperativa, ou seja, além de o cooperado contribuir para o sucesso da cooperativa, esta deve, necessariamente, lhe prestar serviços. Pelo princípio da retribuição pessoal diferenciada o autor afirma que o cooperado deve obter, pelos seus serviços, retribuição superior a que conseguiria caso não estivesse associado à cooperativa.

Percebe-se, assim, a incompatibilidade entre a figura da cooperativa e a utilização desta como mera intermediadora de mão de obra. Entretanto, essa incongruência não foi observada pela maioria dos empregadores rurais logo após a inclusão do parágrafo único no artigo 442 da CLT. A utilização de cooperativas no meio rural se deu de maneira

\footnotetext{
${ }^{150}$ MELO, Raimundo Simão de. Cooperativas de trabalho, cit., p. 50.

${ }^{151}$ DELGADO, Mauricio Godinho. op. cit., p. 329-333.
} 
contrária aos princípios do cooperativismo. Funcionando como mera intermediadora, as cooperativas de mão de obra rural não respeitaram o espírito de proporcionar o aprimoramento do nível social dos cooperados. Contundente é a constatação de Raimundo Simão de Melo ${ }^{152}$, referindo-se à alteração legislativa que incluiu no parágrafo único do artigo 442 da CLT:

"Com efeito, até agora, e no tocante às cooperativas de trabalho, a nova lei tem sido usada em quase $100 \%$ dos casos para fraudar a aplicação do Direito do Trabalho, como já se previa, com conseqüências danosas não só para o trabalhador rural, mas para toda a sociedade."

Retrato disso foi a circular lançada pela Federação da Agricultura do Estado de São Paulo (FAESP) em 1995 prolatando as "vantagens" da contratação de trabalhadores por intermédio de cooperativas, indicando entre outras a supressão do vínculo empregatício, inexistência de fiscalização trabalhista, desobrigação de responsabilidades trabalhistas e sociais ${ }^{153}$. Raimundo Simão de Melo ${ }^{154}$ identifica nessa circular sinalização da disseminação da fraude no cooperativismo no ambiente rural. Nessa conjuntura, o cooperativismo no campo marcou-se pelo fracasso. Nas palavras de Amauri Mascaro Nascimento ${ }^{155}$, "a experiência foi desastrosa no meio rural com a criação de cooperativas formais, na prática inexistentes, para fraudar a legislação trabalhista”.

Diante desse quadro, a doutrina chegou a discutir a respeito da possibilidade ou não de haver, afastados os casos de fraude, cooperativa de mão de obra rural, como aponta Henrique Damiano ${ }^{156}$. De um lado, defendeu-se que a utilização de cooperativas de mão de obra seria incompatível com o artigo 17 da Lei n. ${ }^{\circ}$ 5.889/73, que estende aos trabalhadores rurais não empregados a aplicação dos dispositivos da lei, e o artigo 14 do respectivo regulamento, confirmando e detalhando a extensão. De outro lado, defendeu-se a harmonia entre a legislação rural e a referente às cooperativas, com base no incentivo constitucional à sua implementação e no artigo 11 da Recomendação n. ${ }^{\circ} 127$ da OIT, que prevê o estímulo à organização dos trabalhadores rurais em cooperativas de contratação de mão de obra.

\footnotetext{
${ }^{152}$ MELO, Raimundo Simão de. Cooperativas de trabalho, cit., p. 50.

${ }^{153}$ Três engenheiros perceberam a o significado do documento em artigo que traça interessante perfil do setor citricultor do estado de São Paulo. ALVES, Francisco José da Costa et al. A flexibilização dos direitos trabalhistas chega ao campo: o caso do setor citrícola - o ouro que virou suco. Revista LTr, São Paulo, ano 60. n. 2, p. 220-227, fev. 1996.

${ }^{154}$ MELO, Raimundo Simão de. Cooperativas de trabalho, cit., p. 50.

${ }^{155}$ NASCIMENTO, Amauri Mascaro. Curso de direito do trabalho. 24. ed., cit., p. 898-899.

${ }^{156}$ DAMIANO, Henrique. op. cit., p. 188.
} 
Certamente não seria admissível negar validade a eventual cooperativa de mão de obra rural que se estabelecesse com todos os requisitos formais e materiais, legitimamente criada e voltada à promoção dos interesses dos associados, seu desenvolvimento econômico e social. Principalmente se atendidos os princípios, citados por Maurício Godinho Delgado, da dupla qualidade e retribuição pessoal diferenciada. Tal situação iria ao encontro do prestígio da dignidade dos trabalhadores, já que, cooperados alcançariam condições melhores das que atingiriam se não estivessem reunidos.

Entretanto, o debate acerca da viabilidade ou não da utilização de cooperativas de mão de obra rural não deve, por observar os princípios e regras jurídicas, deixar de enxergar a realidade prática da situação do trabalhador rural. A grande quantidade de fraudes, que culminaram no verdadeiro fracasso da alternativa no meio rural, certamente contou, entre suas razões, com a inadequação entre o modelo cooperativista e as condições materiais das relações trabalhistas rurais.

Entre as características das cooperativas, inclusive impostas pela Lei n. ${ }^{\circ}$ 5.764/71, como a voluntariedade na adesão (art. $\left.4^{\circ}, \mathrm{I}\right)$, soberania da assembleia geral (art. 38 caput) e singularidade de voto nas cooperativas singulares (art. V), percebe-se a necessidade de seus cooperados gerirem seus próprios interesses. Trata-se de associação que pressupõe a capacidade de seus membros de união, organização, autogestão de interesses e de estrutura administrativa que, minimamente, possa lidar com os elementos burocráticos exigidos pela Lei n. ${ }^{\circ}$ 5.764/71. A título de exemplo dessa burocracia, segundo a norma (art. 22), toda cooperativa deve possuir, além dos livros normais fiscais e contábeis, outros cinco livros (livro de matrícula, de atas das assembleias gerais, de atas dos órgãos de administração, de atas do conselho fiscal e de presença dos associados nas assembleias gerais).

Não se trata de criticar os requisitos formais legalmente obrigatórios das cooperativas, ou de afirmar excesso de burocracia. O que se demonstra é, simplesmente, a incompatibilidade entre o cooperativismo e a realidade social e cultural dos trabalhadores rurais, principalmente os costumeiramente contratados por curtos períodos ${ }^{157}$.

\footnotetext{
${ }^{157}$ Os trabalhadores contratados por curtos períodos são, na maioria, os que não apresentaram qualidades suficientes para serem contratados diretamente pelo grande empregador rural, como a usina de álcool ou indústria de suco, por exemplo, que não raro utiliza o contrato de emprego por prazo indeterminado. A agroindústria, por seu poder econômico, seleciona os trabalhadores de maior produtividade, restando para a informalidade, geralmente, os mais idosos ou aqueles, que, por razões indistintas, produzem menos. Exatamente por terem produtividade menor, conseguem remuneração também menor, no tradicional sistema de remuneração por produção, mantendo-se o ciclo de baixo nível econômico e social.
} 
É de conhecimento notório o infelizmente baixo nível de alfabetização no meio rural. Nesse sentido, pertinente é a lição de Maria Ângela Pelegrin ${ }^{158}$, ao afirmar ser um problema cultural, decorrente do baixo nível de alfabetização e escolaridade em geral, o responsável pela dificuldade de se implantar, entre os trabalhadores rurais, ideias como autogestão e auto-organização, "variabilidade do capital social representado por quotaspartes ${ }^{159,}$ e outras inerentes ao cooperativismo. A autora ${ }^{160}$ conclui:

"Por isso, conclui-se, por uma questão prática e sociológica e, em nada, jurídica, com pesar, não se acreditar que o sistema cooperativo, seja capaz de resolver o problema da exploração do homem do campo e dos trabalhadores sem vínculo na zona urbana, embora reconheça a sua legalidade e viabilidade, em tese, quando presente o elemento boa-fé dos dirigentes.".

Ao lado das condições precárias de alfabetização e educação básica dos trabalhadores rurais somam-se as peculiaridades geográficas a dificultar a legítima constituição de cooperativas de mão de obra rurais. Dispersos pelas propriedades rurais, ou alojados nos centros urbanos, é com dificuldade que os trabalhadores rurais, geralmente desprovidos de meios particulares de transporte, conseguirão vencer as grandes distâncias próprias do meio rural para comparecerem às assembleias da cooperativa.

Tudo isso demonstra que as condições materiais das relações de trabalho no campo colocam os trabalhadores em situação de extrema fragilidade, o que dificulta em muitos aspectos a materialização de condições propícias para a criação de cooperativas legítimas e compatíveis com os verdadeiros princípios do cooperativismo ${ }^{161}$.

\footnotetext{
${ }^{158}$ Nas palavras da autora: "Por outro lado, há de se convir, que, no meio rural, onde o analfabetismo (inclusive o semi) impera, a probabilidade de as cooperativas nascerem e se auto-organizarem, isso sim é um entrave natural, principalmente no atual estágio em que se encontra o Brasil, a não ser que o governo estabeleça regras próprias para o cooperativismo rural, dispensando as formalidades e os requisitos que norteiam o instituto, será, mesmo, muito difícil que uma cooperativa sobreviva, sem lesar seus cooperados. Infelizmente, não se tem cultura suficiente para controlar os dirigentes, administradores, governadores. Seria exigir demais que os rurícolas (...) tivessem essa capacidade.” PELEGRINI, Mari Ângela. Trabalhadores sem vínculo rurais e urbanos: do cais ao campo. São Paulo: LTr, 2004. p. 191.

${ }^{159}$ Expressão do inciso II do artigo $4^{\circ}$ da Lei n. ${ }^{\circ}$ 5.764/71.

${ }^{160}$ PELEGRINI, Mari Ângela. op. cit., p. 193.

${ }^{161}$ A reforçar o argumento de que o desenvolvimento do cooperativismo depende de fatores culturais, Raimundo Simão de Melo observa serem as cooperativas mais apropriadas para a reunião de trabalhadores já com um certo grau de autonomia: "A cooperativa de trabalho é criada por profissionais autônomos que se unem em um empreendimento e prestam seus serviços à coletividade e a terceiros, sem nenhuma intermediação. Exemplos: médicos, arquitetos, artistas, auditores, etc. Como se vê, são trabalhadores tipicamente autônomos, por natureza.” MELO, Raimundo Simão de. Cooperativas de trabalho, cit., p. 50.
} 
Essa fragilidade permitiu que se chegasse ao ponto relatado por Francisco Jose da Costa Alves e Luiz Fernando Paulillo ${ }^{162}$, na citricultura paulista, em que o trabalhador rural somente conseguiria trabalho caso se submetesse às precárias condições das cooperativas fraudulentas, dada a intensa disseminação da prática ilícita.

Duramente combatidas pelo Estado, através da Auditoria-Fiscal do Trabalho, Ministério Público do Trabalho e Poder Judiciário, a prática das cooperativas fraudulentas foi arrefecida. O exemplo acabou por tornar evidente que, se deixados sem rédeas, os atores sociais envolvidos podem retornar ao sistema de exploração extrema do hipossuficiente, com situações degradantes e desumanas ${ }^{163}$, afrontando direitos fundamentais e, consequentemente, a dignidade do trabalhador rural.

Assim, algumas alternativas para a proteção jurídica do trabalhador rural contratado por curto período se apresentam. Aventou-se a possibilidade de utilização da sistemática do trabalho avulso. Às cooperativas propuseram os próprios atores sociais envolvidos a alternativa do consórcio de empregadores rurais. Mais recentemente, foi editada a medida provisória n. ${ }^{\circ} 410 / 07$, posteriormente convertida em Lei n. ${ }^{\circ} 11.718 / 08$, acrescentando o artigo 14-A à lei n. ${ }^{\circ} 5.889 / 73$ e criando assim o contrato de trabalho rural por pequeno prazo. Três alternativas que possuem, cada uma, aspectos positivos e negativos, tendo todas o mérito de representar a procura pela inclusão do rurícola, especialmente o contratado por curtos períodos, no sistema de proteção trabalhista e previdenciário. Tratase da defesa da dignidade do trabalhador rural, algo imprescindível à luz da valorização constitucional do trabalho. Antes, porém, de analisá-las, é pertinente pontuar as principais características dos elementos da relação de emprego rural.

\footnotetext{
${ }^{162}$ Nas palavras dos autores: "tornar-se cooperado deixou de ser uma opção livre dos trabalhadores para transformar-se num ato compulsório: só consegue emprego se pertencer a uma cooperativa.”. ALVES, Francisco José da Costa; PAULILLO, Luiz Fernando. Sindicato dos trabalhadores avulsos: a agricultura paulista sai na frente, cit., p. 1053.

${ }^{163}$ Raimundo Simão de Melo relata a constatação de trabalho análogo ao de escravo sob a roupagem de cooperativa: "os argumentos daqueles que idealizam as cooperativas de trabalho como formas de reduzir custos trabalhistas e criar empregos são falsos, cruéis e em muitos casos criminosos, pois o que se está apurando na prática são explorações vergonhosas que caracterizam formas de trabalho escravo, intermediado por criminosas cooperativas de trabalho. Como comprovação do alegado, relembremos o fato que deixou o Brasil todo estarrecido, quando a imprensa escrita e falada noticiou e mostrou a existência de trabalho degradante, em condições subumanas, intermediado por cooperativas de trabalho. e isto no estado de São Paulo, o mais rico e desenvolvido da Federação. Aquelas matérias mostraram apenas uma pequena parte do resultado de blitze feitas pelo Ministério Público do Trabalho e Ministério do Trabalho, com apoio da Polícia Federal, quando se constatou a existência de trabalhadores aliciados de outros estados, trabalhando e vivendo em condições deprimentes e desumanas, praticamente por pratos de comida de péssima qualidade. Entre esses trabalhadores, como mostraram as maiores redes de televisão do país, estavam crianças de apenas 10 anos de idade, às quais é negado o sagrado direito à infância e à escola." MELO, Raimundo Simão de. Flexibilização dos direitos trabalhistas e as cooperativas de trabalho. Revista do Ministério Público do Trabalho, Brasília, v. 8, n. 15, p. 67, 1998.
} 


\title{
2. ELEMENTOS DA RELAÇÃO DE TRABALHO RURAL
}

\subsection{Empregador rural}

Não há maiores controvérsias a respeito da definição de empregador rural, estampada na própria Lei n. ${ }^{\circ}$ 5.889/73:

\begin{abstract}
Art. $3^{\circ}$ - Considera-se empregador, rural, para os efeitos desta Lei, a pessoa física ou jurídica, proprietário ou não, que explore atividade agroeconômica, em caráter permanente ou temporário, diretamente ou através de prepostos e com auxílio de empregados.
\end{abstract}

Observa-se a possibilidade de ser empregador rural mesmo aquele que não é proprietário da terra, bastando explorar atividade agroeconômica. A legislação prevê também a figura do empregador rural mediante exploração de atividade industrial em estabelecimento agrário rural $\left(\S 1^{\circ}\right.$ do artigo $\left.3^{\circ}\right)$, formação de grupo econômico ou financeiro rural $\left(\S 2^{\circ}\right.$ do artigo $\left.3^{\circ}\right)$ e o chamado empregador rural por equiparação $\left(\operatorname{art.~} 4^{\circ}\right)$.

A identificação do empregador rural guarda íntima ligação com a identificação do empregado rural, pois este, para ser assim considerado, deve prestar serviços a “empregador rural”, nos termos do artigo $2^{\circ}$ da Lei n. ${ }^{\circ}$ 5.889/73. Assim, acredita-se, a análise das duas figuras deve se dar conjuntamente, o que passa a ser feito a seguir.

\subsection{Empregado e trabalhador rural}

Ao definir as características do empregado rural, a doutrina é unânime ao afirmar ser ele, hoje em dia, tal qual o empregado urbano (regido pela CLT), acrescentando-se, unicamente, a característica de ser rural ${ }^{164}$.

\footnotetext{
${ }^{164}$ Pode-se citar, entre outros, Gustavo Filipe Barbosa Garcia: “Por ser empregado, aplicam-se ao rural os requisitos, já estudados, da relação de emprego: pessoa física, pessoalidade, não eventualidade, subordinação e onerosidade. Assim, cabe enfatizar os requisitos que diferenciam o empregado rural do empregado urbano". GARCIA, Gustavo Filipe Barbosa. op. cit., p. 238. No mesmo sentido afirmam: Sérgio Pinto Martins: "O empregado rural tem que atender aos mesmos requisitos já mencionados quanto a e empregado urbano para ser considerado empregado: ser pessoa física, prestar serviços de natureza contínua, mediante subordinação, pessoalmente e com pagamento de salário”. MARTINS, Sergio Pinto. Direito do trabalho. 27. ed. São Paulo: Atlas, 2011. p. 151. José Otávio de Souza Ferreira: "Partindo-se do
} 
A Lei n. ${ }^{\circ} 5.889 / 73$ utiliza o termo "empregado", não deixando dúvida a respeito da sua qualificação como tal:

Art. $2^{\circ}$ Empregado rural é toda pessoa física que, em propriedade rural ou prédio rústico, presta serviços de natureza não eventual a empregador rural, sob a dependência deste e mediante salário.

Nem sempre foi assim. O antigo Estatuto do Trabalhador Rural (ETR) Lei n. ${ }^{\circ}$ 4.214/63, utilizava o termo "trabalhador":

Art. $2^{\circ}$ : trabalhador rural, para os efeitos desta lei, é toda pessoa física que presta serviços a empregador rural, em propriedade rural ou prédio rústico, mediante salário pago em dinheiro ou in natura, ou parte in natura e parte em dinheiro.

A doutrina divergia, então, sobre o alcance do artigo $2^{\circ}$ do ETR. Observou Mozart Victor Russomano ${ }^{165}$ a ausência, no artigo, dos elementos não eventualidade e dependência hierárquica, presentes na definição celetista de empregado. Não obstante, o autor identificou os elementos da relação de emprego em função da pessoa para quem se trabalha, o empregador. Se em um dos lados da relação está empregador, do outro só poderia estar empregado. Cesarino Jr. ${ }^{166}$ lecionava na mesma direção. Por outro lado, parte da doutrina entendia que o artigo $2^{\circ}$ do Estatuto do Trabalhador Rural se referia não apenas

conceito acima exposto de contrato de trabalho, conclui-se que para chegarmos ao conceito de contrato de trabalho rural, é só adicionarmos a qualificação 'rural' ao empregado e empregador, bem como o local da prestação dos serviços, ou seja, propriedade rural ou prédio rústico”. FERREIRA, José Otávio de Souza. Relação de emprego rural. In: GIORDANI, Francisco Alberto da Motta Peixoto; MARTINS, Melchíades Rodrigues; VIDOTTI, Tarcio José (Coords.). Direito do trabalho rural: homenagem a Irany Ferrari, cit., p. 404. Maurício Godinho Delgado: "Não há dúvida de que em sua composição essa figura sociojurídica apresenta os mesmos elementos fático-jurídicos integrantes da relação de emprego, isto é, pessoa física, pessoalidade, não eventualidade, onerosidade e subordinação”. DELGADO, Mauricio Godinho. op. cit., p. 383.

${ }^{165}$ RUSSOMANO, Mozart Victor. Comentários ao Estatuto do Trabalhador Rural. 2. ed. São Paulo: Ed. Revista dos Tribunais. 1969. v. 1, p. 16.

166“'Logo, o 'trabalhador do ETR é realmente o 'empregado' da CLT, com as diferenças próprias à natureza especial do trabalho considerado. Aliás, o art. $2^{\circ}$ do ETR fala em 'serviços a empregador rural', e somente o empregado pode prestar serviços a 'empregador', pois qualquer outra pessoa prestará serviços à empresa, mas não ao empregador. Por outro lado bastará percorrer o ETR para ver que nêle o têrmo 'trabalhador' é usado como perfeito sinônimo de 'empregado', às vezes em artigos sucessivos (Cf. artigos 34, 38, 42, 43, 44, 66, 69, 71, 72, 74 a 76 e notadamente 78 sôbre penalidade de índole disciplinar... ao trabalhador rural)." CESARINO JUNIOR, Antonio Ferreira. Direito social brasileiro. 6. ed. São Paulo: Saraiva, 1970. v. 2, p. 117. 
aos empregados, mas aos diversos tipos de trabalhadores rurais. Com esse entendimento pode-se citar, entre outros ${ }^{167}$, Alice Monteiro de Barros ${ }^{168}$.

A Lei n. ${ }^{\circ}$ 5.988/73, ao utilizar o termo "empregado" evitou a controvérsia, deixando claro que suas normas são aplicáveis, a princípio, aos empregados rurais. Não obstante, mais adiante, no artigo 17, a lei estendeu a aplicação de seus preceitos, "no que couber, aos trabalhadores rurais não compreendidos na definição do artigo $2^{\circ}$, que prestam serviços a empregador rural". 169

Octávio Bueno Magano ${ }^{170}$, afirmando que a nova Lei n. ${ }^{\text {5 }} 5.889 / 73$ representou alteração no conceito do sujeito protegido pela norma, observa:

"O exagero da lei de que resultava a sua incidência indiscriminada sobre serviços tradicionalmente considerados autônomos, tais como os regulados pelo contrato de parceria e de arrendamento, foi corrigido pela Lei n. $^{\circ} 5.889$, de 8 de junho de 1973, que limitou a sua incidência ao trabalhador subordinado, só excepcionalmente admitindo a extensão de seus dispositivos a outros trabalhadores. (...) Hoje, portanto, não há possibilidade de dúvida: a lei brasileira de proteção ao trabalho rural se aplica, em regra, ao trabalhador subordinado. Excepcionalmente, no que couber, pode ser estendida a outros trabalhadores."

Desse modo, com a edição da Lei n. ${ }^{\circ}$ 5.889/73, ficou isento de dúvida que estão presentes na relação empregatícia rural os mesmos requisitos comumente identificados na relação de emprego urbano, subordinação, onerosidade, pessoalidade, não eventualidade. Cabe esclarecer, então, os elementos que diferenciam o empregado rural do urbano.

\footnotetext{
167 “O ETR (art. $2^{\circ}$ ) não define apenas o empregado rural, mas, sim, o 'trabalhador rural'. (...). Apesar das opiniões em contrário, a definição é de 'trabalhador rural', e não de empregado rural. Dela nada consta sobre dependência ou similar.” CATHARINO, José Martins. op. cit., v. 1, p. 193.

168 "Como se pode verificar, o Estatuto atribuiu ao rurícola um conceito mais amplo do que aquele previsto para o empregado celetista, e tanto é que, em vez de usar o termo 'empregado', utilizou-se da expressão 'trabalhador'. Ao que parece, não ocorreu, na hipótese, erro de técnica, como bem assevera Evaristo de Moraes Filho. Ao contrário, teve-se em mira ampliar o conceito, a fim de abranger todos aqueles trabalhadores que não possuem dependência econômica e social, não obstante opiniões em sentido oposto. Logo, ainda com amparo na doutrina de Evaristo de Moraes Filho, o Estatuto abrangeu, no art. $2^{o}$, não só o empregado rural, mas também o tarefeiro, o parceiro agrícola e pecuário, independentemente do tipo de contrato e sistema de pagamento." BARROS, Alice Monteiro de. Curso de direito do trabalho, cit., p. 321-322.

${ }^{169}$ Interessante notar que o artigo 17 prevê a possibilidade de trabalhadores não empregados prestarem serviços a empregador rural, o que contraria a argumentação segundo a qual se em um dos polos da relação jurídica está empregador, do outro lado só poderia estar empregado.

${ }^{170}$ MAGANO, Octávio Bueno. Manual de direito do trabalho. 2. ed. São Paulo: LTr. 1984. v. 2, p. 106.
} 


\title{
2.3. Empregado rural e empregado urbano
}

\subsubsection{Critério da CLT}

Já em 1943 a CLT cuidou de definir critérios para a caracterização do trabalhador rural. Era importante diferenciar esse tipo de trabalhador, pois ele fora excluído da proteção consolidada, exceto por alguns artigos isolados, aplicáveis por disposição expressa da norma. Assim foi redigido o artigo $7^{\circ}$, alínea "b" da CLT:

\begin{abstract}
Art. $7^{\circ}$ : Os preceitos constantes da presente Consolidação salvo quando for em cada caso, expressamente determinado em contrário, não se aplicam :

b) aos trabalhadores rurais, assim considerados aqueles que, exercendo funções diretamente ligadas à agricultura e à pecuária, não sejam empregados em atividades que, pelos métodos de execução dos respectivos trabalhos ou pela finalidade de suas operações, se classifiquem como industriais ou comerciais;
\end{abstract}

Octávio Bueno Magano ${ }^{171}$ criticou os critérios celetistas, por não atenderem à "realidade sociológica do habitat do trabalhador". A identificação do trabalhador rural se deu a partir das funções exercidas pelo obreiro, diretamente ligadas à agricultura e à pecuária, dos métodos de execução dos respectivos trabalhos e da finalidade das operações. Na opinião de Rusinete Dantas de $\operatorname{Lima}^{172}$, a legislação conjugava dois critérios, a natureza das atividades prestadas pelo trabalhador e a natureza da atividade econômica do

\footnotetext{
171،De acordo com os apontados critérios, o tratorista, tendo em vista os métodos de execução de seu trabalho, não era considerado rural e muito menos os peões, boiadeiros ou campeiros, quando a atividade da Fazenda convergisse para o abate e a industrialização da carne. Os critérios em causa eram falhos porque não atendiam à realidade sociológica do habitat do trabalhador, a qual absolutamente não se alterava nem pelos métodos de execução das tarefas respectivas nem pela finalidade econômica perseguida pelo empregador.” MAGANO, Octávio Bueno. op. cit., v. 2, p. 107.

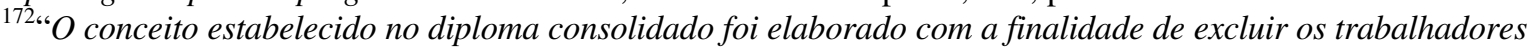
rurais do quadro jurídico-laboral, utilizando-se o legislador, ou quem suas funções tenha desempenhado, de dois critérios distintos para desenhar a exata qualificação do tipo em questão, caracterizado, em princípio, pelo exercício real da atividade do campo, pura e simplesmente. O outro critério auxiliar levava em conta os métodos de execução ou a finalidade de ação da empresa, como também, das operações que a empresa desenvolvia. Na segunda hipótese, era levada em consideração a atividade do empregador (empresa industrial ou comercial). Neste caso, o trabalhador, mesmo exercendo atividade nitidamente rural, teria a proteção da lei trabalhista, considerado, para todos os efeitos, como industriário ou comerciário". LIMA, Rusinete Dantas de. O trabalho rural no Brasil. São Paulo: LTr, 1992. p. 24.
} 
empregador. Entretanto, esse entendimento não era pacífico, como bem observa Alice Monteiro de Barros ${ }^{173}$ :

"Havia os que entendiam que as expressões 'método de execução dos respectivos trabalhos' e 'finalidade de suas operações' diziam respeito às atividades do empregado, logo, consideravam como determinante para a classificação do empregado rural a natureza da atividade por ele exercida e não a atividade preponderante da empresa. (...) A outra interpretação era no sentido de que a expressão 'finalidade de suas operações', contida no texto consolidado, referia-se à empresa, não estabelecendo, portanto, qualquer distinção entre esses empregados, que deveriam ser enquadrados consoante a atividade preponderante da empresa".

A segunda interpretação pode ser encontrada na obra Instituições de Direito do Trabalho, em trecho de Délio Maranhão, atualizado por Teixeira Lima ${ }^{174}$. Argumenta-se que a lei, ao utilizar o termo "atividades", se referia não às do trabalhador, mas às do empregador. Também a expressão "métodos de execução" se ligava a essas atividades, do empregador, não do empregado. Considerando a finalidade lucrativa, própria da exploração e da atividade econômica, o autor lembra que quem exerce tal exploração é o empregador. É ele quem pratica atividade econômica, como agricultor ou pecuarista. O trabalho do empregado é mero fator de produção, e nessa medida, está "diretamente ligado" à atividade praticada pelo empregador. O autor ${ }^{175}$ ressalta, ainda, que a categoria profissional do empregado é "legalmente definida pela atividade do empregador, não pela natureza do serviço prestado" ${ }^{176}$. Nas situações em que o empregador exercia atividades rurais e não rurais, o autor ${ }^{177}$ ensinava ser necessário apurar a independência da atividade

\footnotetext{
${ }^{173}$ BARROS, Alice Monteiro de. Curso de direito do trabalho, cit., p. 321.

174 "Entendiam alguns que as atividades a que se referia a lei eram as dos empregados: a classificação profissional decorria da natureza dos serviços prestados. Assim, o carpinteiro que prestasse serviços em uma granja não seria trabalhador rural. E argumentavam que a Consolidação falava no exercício das funções 'diretamente' ligadas à agricultura ou à pecuária. Estamos em que não era este o melhor entendimento. É a finalidade da exploração econômica que a caracteriza ou não como agrícola ou pecuária. Quem exerce a atividade econômica, como agricultor ou pecuarista, é o empregador. O trabalho do empregado é simples fator de produção utilizado na aludida exploração. Desde que o serviço prestado contribua para aquela finalidade, a ela estará diretamente ligado. A categoria profissional do empregado, é bom lembrar, é legalmente definida pela atividade do empregador, e não pela natureza do serviço prestado (...). O art. $7^{\circ}$, b, fazia menção às 'atividades' em que os trabalhadores são empregados, e não àquelas por eles exercidas. Tais atividades são as do estabelecimento." SÜSSEKIND, Arnaldo; MARANHÃO, Délio; VIANNA, Segadas; TEIXEIRA FILHO, João de Lima. Instituições de direito do trabalho. 20. ed. atual. São Paulo: LTr. 2002. v. 1, p. 183-184.

${ }^{175}$ Id., loc. cit.

${ }^{176}$ De fato, o $§ 2^{\circ}$ do artigo 511 da CLT define categoria profissional em função da atividade econômica: “a similitude de condições de vida oriunda da profissão ou trabalho em comum, em situação de emprego na mesma atividade econômica ou em atividades econômicas similares ou conexas, compõe a expressão social elementar compreendida como categoria profissional."

${ }^{177}$ Id. Ibid.
} 
agrícola, ou seu caráter acessório em relação à atividade comercial ou industrial do empregador.

Nesse sentido, o Supremo Tribunal Federal publicou a Súmula n. ${ }^{\circ}$ 196, segundo a qual "ainda que exerça atividade rural, o empregado de empresa industrial ou comercial é classificado de acordo com a categoria do empregador". Trata-se de interpretação jurisprudencial fixada antes da edição do Estatuto do Trabalhador Rural, preocupada com a inclusão dos trabalhadores do campo no sistema previdenciário e de proteção celetista ${ }^{178}$. A preocupação se justificava, pois, como visto, os trabalhadores rurais, nessa época, careciam da tutela jurídica e social que o ETR, e mais tarde a Lei n. ${ }^{o}$ 5.889/73, viriam representar, gozando apenas de direitos esparsamente previstos, em artigos isolados da CLT.

\subsubsection{Critério da Lei n. $^{\circ} 4.214 / 63$}

O Estatuto do Trabalhador Rural (ETR), Lei n. 4.214 de 02 de março de 1963, substituiu o modo celetista pelo qual se caracterizava o trabalhador como rural:

Lei n. ${ }^{\circ} 4.214 / 63$, art. $2^{\circ}$ : Trabalhador rural para os efeitos desta é toda pessoa física que presta serviços a empregador rural, em propriedade rural ou prédio rústico, mediante salário pago em dinheiro ou in natura, ou parte in natura e parte em dinheiro.

Permaneceu controversa a questão. Pode ser citado o entendimento de José Martins Catharino $^{179}$, para quem era a natureza dos serviços prestados pelo trabalhador o que definia o trabalho como rural, em oposição ao urbano. $\mathrm{O}$ autor ${ }^{180}$ forneceu um conceito de contrato de emprego rural: "legalmente, portanto, contrato de emprego rural é aquele pelo qual uma ou mais pessoas naturais (físicas) se obrigam, por remuneração, a prestar serviços rurais, ou equiparados, a outra pessoa, sob a direção desta.”.

Destaca-se que, na definição apresentada, que o adjetivo "rurais" qualifica os serviços prestados, confirmando a ideia de que era a natureza da atividade do empregado que o qualificava como rural, na visão do autor.

\footnotetext{
${ }^{178}$ BARROS, Alice Monteiro de. Curso de direito do trabalho, cit., p. 321.

${ }^{179}$ Nas suas palavras: "O fator qualificativo ou caracterizante do contrato de emprego rural, como tipo do de emprego, é o seu conteúdo, sua estrutura, sua interioridade. Em suma: a natureza e a finalidade do trabalho do empregado, e não a atividade externa do empregador, que podem ser várias". CATHARINO, José Martins. op. cit., v. 1, p. 369-371.

${ }^{180}$ Id. Ibid., p. 371.
} 
Já para Mozart Victor Russomano ${ }^{181}$, ficou claro não ser decisiva a natureza das atividades exercidas pelo trabalhador. Comentando o Estatuto o autor afirma ter-se abandonado o critério do artigo $7^{\circ}$, alínea "b" da CLT, importando saber, a partir da nova lei, se a empresa seria ou não agrícola.

De fato, o Estatuto do Trabalhador Rural definia como trabalhador rural aquele que prestasse serviços a empregador rural, em propriedade rural ou prédio rústico. No texto legal o adjetivo "rural" não qualifica o serviço prestado, mas o empregador, o que reforça a ideia de que é a atividade deste, não do empregado, a que merece atenção. Percebe-se que o ETR utilizava, ao definir o trabalhador rural, dois elementos: para quem o serviço era prestado (empregador rural) e o local onde o serviço era prestado (propriedade rural ou prédio rústico).

Com relação ao local da prestação dos serviços, há duas possibilidades, propriedade rural e prédio rústico. Não há controvérsias a respeito de propriedade rural, sendo cediço que se trata de propriedade localizada em área rural, não urbana. Trata-se de condição geográfica, aferida a partir da localização, urbana ou rural, da propriedade em que os serviços são executados ${ }^{182}$.

Também não tem dúvidas a respeito da conceituação da outra possibilidade, prédio rústico. Prédio pode ser entendido como qualquer imóvel, edificado ou não, em zona urbana ou rural, não importando a destinação que lhe é dada ${ }^{183}$. Rústico será aquele destinado a atividades rurais, ou agroeconômicas. A doutrina é uníssona ao afirmar não ser

181 “Abandonou-se, portanto, o critério do art. 7", alínea "b”, da Consolidação, que descaracterizava a relação de emprego rural quando, pelos métodos empregados na execução do serviço ou pela finalidade das operações agrícolas, os trabalhadores pudessem ser classificados como industriários ou comerciários.

Agora, simplificando-se a questão, apenas importa saber se a empresa a que está vinculado o trabalhador rural é, na verdade, uma empresa agrícola.” RUSSOMANO, Mozart Victor. op. cit., p. 20.

${ }^{182}$ Gustavo Filipe Barbosa Garcia é lacônico sobre o tema: "Analisando o mencionado art. $2^{\circ}$ da Lei n. 5.889/1973, observa-se a menção de que o empregado rural presta serviços 'em propriedade rural ou prédio rústico’. A propriedade rural é aquela situada na zona rural.” GARCIA, Gustavo Filipe Barbosa. op. cit., p. 238.

${ }^{183}$ Afirma Washington de Barros Monteiro: "Antes de mais nada, convém esclarecer qual seja a exata extensão da palavra prédio. Segundo alguns glotólogos, o vocábulo só se aplicaria aos edifícios e construções. Em direito civil, entretanto, a palavra tem sentido muito mais amplo. Aliás, já no direito romano, praedium era toda espécie de imóvel, com ou sem construção, sendo certo mesmo que, primitivamente, significava tão somente o solo.

No direito pátrio, de modo idêntico, o termo se aplica a qualquer espécie de imóvel, edificado ou não, embora algumas vezes se atribuam também nomes peculiares ao não edificado, como solo, chão, terreno. A palavra prédio exprime, pois, de ordinário, o solo conjuntamente com o edifício, e outras vezes, o terreno tão-somente; terreno cultivado ou não, terreno edificado ou não, morada, sítio, fazenda, tudo pode ser abrangido pela expressão genérica prédio." MONTEIRO, Washington de Barros. Curso de direito civil: direito das obrigações. São Paulo: Saraiva. 1956. v. 2, p. 176. No mesmo sentido, Maria Helena Diniz: "Prédio: Direito Civil. 1 Imóvel, urbano ou rural, edificado ou não. 2. Bem de raiz. 3. Terra; terreno. 4. Moradia. 5. Casa. 6. Edifício. 7. Bem imobiliário. DINIZ, Maria Helena. Dicionário jurídico. São Paulo: Saraiva, 1998. v. 3, p. 684. 
importante a localização, urbana ou rural, do prédio, mas sim sua destinação, finalidade, para ser considerado rústico ${ }^{184}$. Pode-se citar Sérgio Pinto Martins ${ }^{185}$ :

"Prédio rústico é o destinado à exploração agrícola, pecuária, extrativa ou agroindustrial. Pode até estar localizado no perímetro urbano, mas deve ser utilizado na atividade agroeconômica. Não é, portanto, a localização que irá indicar se o prédio é rústico ou urbano, mas se é destinado á atividade agroeconômica".

A legislação, apesar de não ter definido propriedade rural e prédio rústico, cuidou da definição do outro elemento utilizado na caracterização do trabalhador rural, qual seja, para quem o trabalho é prestado, o "empregador rural". A definição de empregador rural foi apresentada no artigo $3^{\circ}$ do ETR, segundo o qual era a: "pessoa física ou jurídica, proprietária ou não, que explore atividades agrícolas, pastoris ou na indústria rural, em caráter temporário ou permanente, diretamente ou através de prepostos.”.

O $\S 1^{\circ}$ do mesmo artigo trazia a definição de indústria rural como "atividade industrial exercida em qualquer estabelecimento rural não compreendido na CLT”. Havia ainda o empregador rural por equiparação, conforme artigo $4^{\circ}$ do Estatuto ${ }^{186}$.

Pode-se notar que a caracterização do empregador como rural estava calcada na sua atividade econômica, não importando a localização geográfica da sua empresa ou propriedade. Há que se perceber a relevância da atividade econômica do empregador como principal critério para definir o trabalhador como rural, pois tanto na definição de prédio rústico, quanto na de empregador rural, essa atividade era elemento determinante.

Nesse contexto, José Martins Catharino ${ }^{187}$ classificou o contrato de trabalho rural, na vigência do Estatuto do Trabalhador Rural, em: a) contrato de trabalho rural própria e

\footnotetext{
${ }^{184}$ Registra-se, entre outros: Gustavo Filipe Barbosa Garcia: “O prédio Rústico pode ser entendido como aquele que, situado na zona rural ou mesmo em zona urbana, tem como destinação a exploração de atividade agroeconômica.” GARCIA, Gustavo Filipe Barbosa. op. cit., p. 238. No mesmo sentido: SILVA, De Plácido e. Vocabulário jurídico conciso. Atual. por Nagib Slaibi Filho e Gláucia Carvalho. 2. ed. atual. Rio de Janeiro: Forense, 2010. p. 597. MONTEIRO, Washington de Barros. op. cit., v. 2, p. 176. PEREIRA, Caio Mario da Silva. Instituições de direito civil: contratos. 15. ed. Rio de Janeiro: Forense, 2011. v. 3, p. 252 e VENOSA, Silvio de Salvo. Direito civil: contratos em espécie. 11. ed. São Paulo: Atlas. 2011. v. 3, p. 139.

${ }^{185}$ MARTINS, Sergio Pinto. Direito do trabalho, cit., p. 151.

${ }^{186} \mathrm{Art} .4^{\circ}$ Equipara-se ao empregador rural toda pessoa física ou jurídica que, por conta de terceiro, execute qualquer serviço ligado às atividades rurais, mediante utilização do trabalho de outrem.

187“ $O$ art. $2^{\circ}$ do ETR, ao definir o trabalhador rural como quem presta serviços a empregador rural, perfilha o critério mesológico: que trabalha 'em propriedade ou prédio rústico'.

Ao definir (art. $3^{\circ}$ ) o empregador rural, tem-no como 'proprietário ou não, que explore atividades agrícolas, pastoris ou na indústria rural...'. Destarte, combinando os dois critérios, o mesológico e o econômico, temos que o contrato em causa pode ser: rural, própria e exclusivamente, agrícola ou pastoril, e rural-industrial, desde que o trabalho do empregado seja realizado no meio rural. O que seja 'indústria rural' está definido
} 
exclusivamente, com trabalho praticado nas atividades agrícolas e pastoris; b) ruralindustrial, com trabalho desenvolvido em indústrias rurais, definidas no próprio estatuto legal e c) rural impróprio, com trabalho em qualquer serviço ligado às atividades rurais, para empregador por equiparação, conforme artigo $4^{\circ}$ do estatuto.

Sobre o conceito de empregador rural por equiparação, José Martins Catharino ${ }^{188}$ observa a grande ampliação que houve, podendo ser considerado empregador rural por equiparação até mesmo quem "constrói um curral”.

\subsubsection{Critério da Lei n. ${ }^{\circ} 5.889 / 73$}

Dez anos após a sua edição, o Estatuto do Trabalhador Rural foi expressamente revogado pela Lei n. 5.889 , de 8 de junho de $1973^{189}$. A nova lei, ao diferenciar o empregado rural do urbano, utilizou os mesmo critérios, é dizer, manteve a determinação de que é rural o empregado que presta serviço em propriedade rural ou prédio rústico, para empregador rural. Conforme artigo $3^{\circ}$ da Lei n. ${ }^{\circ}$ 5.889/73, é a atividade econômica deste que o define como tal ${ }^{190}$. Em última análise, a atividade econômica do empregador continuou a ser fator determinante para definir o empregado como rural ${ }^{191}$.

pelo mesmo critério adotado para definir o trabalhador rural: a "exercida em qualquer estabelecimento rural" $\left(\$ 1^{\circ}\right.$ do art. $\left.3^{\circ}\right)$.

Extensivamente, também é considerado contrato de emprego rural o relativo a 'qualquer serviço ligado às atividades rurais', nos termos do art. $4^{\circ}$. O que podemos chamar de rural impróprio (exs.: construções de currais, cocheiras, etc.; de tanques ou aguadas; serviços de irrigação , e de eletrificação; abertura de estradas; serviços mecanizados, etc.).

Legalmente, portanto, contrato de emprego rural é aquele pelo qual uma ou mais pessoas naturais (físicas) se obrigam, por remuneração, a prestar serviços rurais, ou equiparados, a outra pessoa, sob a direção desta." CATHARINO, José Martins. op. cit., v. 1, p. 371.

188“ $O$ artigo $4^{\circ}$ (do ETR) amplia consideravelmente o conceito básico acima pela extensão que dá ao de ruralidade. Realmente, equipara 'empregador rural toda pessoa física ou jurídica que, por conta de terceiro, execute qualquer serviço ligado à atividades rurais, mediante utilização de trabalho alheio. Assim, muitas atividades não rurais são tidas como tais para efeito da caracterização do empregador rural, se entre elas houver ligação. Apesar das controvérsias sobre sua interpretação, temos ser possível qualquer empregador ser tido como rural desde que execute, 'por conta de terceiro', 'qualquer serviço ligado às atividades rurais, mediante utilização de trabalho alheio'. Exemplo: é tido como rural quem, com empregados seus, execute, para e por conta de empregador rural em sentido estrito, serviços relativos à construção de um curral.” Id. Ibid., v. 1, p. 163.

${ }^{189}$ Art. 21 da Lei n. ${ }^{\circ}$ 5.889/73: Esta lei entra em vigor na data de sua publicação, revogadas as disposições em contrário, em especial a Lei 4.214, de 2 de março de 1963, e o Decreto-lei 761, de 14 de agosto de 1969.

${ }^{190}$ Lei n. ${ }^{\circ} 5.889 / 73$, art. $3^{\circ}$ : “Considera-se empregador rural, para os efeitos desta lei, a pessoa física ou jurídica, proprietário ou não, que explore atividade agroeconômica, em caráter permanente ou temporário, diretamente ou através de prepostos e com auxílio de empregados".

${ }^{191}$ Aurélio Pires, ao tratar da lei $n .{ }^{\text {o }} 5.889 / 73$, identifica a atividade econômica do empregador como elemento a ser destacado, mesmo quando a lei se refere a "prédio rústico": "Propriedade rural ou prédio rústico: 
Sérgio Pinto Martins ${ }^{192}$ observa: "o elemento preponderante , por conseguinte, é a atividade do empregador. Se o empregador exerce atividade agroeconômica com finalidade de lucro, o empregado será rural, mesmo que trabalhe no perímetro urbano da cidade”.

Nesse contexto, será rural o trabalhador do escritório da fazenda, se a atividade econômica desta, empreendida pelo empregador, for rural, ou agroeconômica ${ }^{193}$. Mas não será rural o trabalhador que, com atividades ligadas à terra, se ativar em chácara de lazer, sem fins lucrativos ${ }^{194}$. A SDI - I do O TST publicou a Orientação Jurisprudencial n. ${ }^{\text {o } 315,}$ segundo a qual: "É considerado trabalhador rural o motorista que trabalha no âmbito de empresa cuja atividade é preponderantemente rural, considerando que, de modo geral, não enfrenta o trânsito das estradas e cidades."

A lei n. ${ }^{o}$ 5.889/73 manteve a figura da indústria rural, afirmando estar incluída na atividade econômica referida no caput do artigo $3^{\circ}$ a exploração industrial em estabelecimento agrário não compreendido na CLT. O Regulamento da Lei n. ${ }^{\circ}$ 5.889/73, aprovado pelo Decreto n. ${ }^{\circ} 73.626 / 74$, detalha o conceito de indústria rural (art. $2^{\circ}, \S \S 4^{\circ} \mathrm{e}$ $5^{\circ}$ ), esclarecendo se tratar de atividades que compreendam o primeiro tratamento dos produtos agrários in natura, sem transformá-los em sua natureza e sem lhes retirar a condição de matéria prima. Os incisos I e II do $\S 4^{\circ}$ do artigo $2^{\circ}$ do referido Decreto exemplificam atividades industriais rurais:

I - o beneficiamento, a primeira modificação e o preparo dos produtos agropecuários e hortifrutigranjeiros e das matérias-primas de origem animal ou vegetal para posterior venda ou industrialização;

II - o aproveitamento dos subprodutos oriundos das operações de preparo e modificação dos produtos in natura, referidos no item anterior.

áreas de terras onde se explora atividade agroeconômica ou na indústria rural. Hoje é fora de dúvida que não é a localização do imóvel que confere a condição de rural, mas sim a sua destinação. O que interessa, é a natureza da atividade desenvolvida na propriedade, prédio ou indústria, para a caracterização do empregado como rural e não a função por ele exercida”. PIRES, Aurélio. Aspectos teóricos e práticos sobre trabalho rural. 5. ed. rev. atual. São Paulo: LTr, 1996. p. 41.

${ }^{192}$ MARTINS, Sergio Pinto. Direito do trabalho. 27. ed., cit., p. 151. No mesmo sentido, Gustavo Filipe Barbosa Garcia: "Como se nota, a questão essencial, para saber se o empregador é rural e, por consequência, o empregado também, é a finalidade da atividade explorada por aquele, de natureza agroeconômica, ou seja, direcionada à agricultura ou à pecuária. A função, em si, desempenhada pelo empregado, não é o fator relevante na referida caracterização do empregado como rural, mas sim a natureza da atividade desempenhada pelo empregador. Portanto, não mais prevalece a orientação do art. $7^{o}, b$, da CLT (1943), que considerava como rurais os trabalhadores que exercessem 'funções diretamente ligadas à agricultura e à pecuária”'. GARCIA, Gustavo Filipe Barbosa. op. cit., p. 239.

${ }^{193}$ GARCIA, Gustavo Filipe Barbosa. op. cit., p. 239.

${ }^{194}$ Será empregado doméstico. Nesse sentido, entre outros: Id. Ibid., p. 239. 
Gustavo Filipe Barbosa Garcia dá o exemplo do primeiro beneficiamento do $\operatorname{arroz}^{195}$.

A Lei n. ${ }^{\circ} 5.889 / 73$ trouxe, como já previa o antigo ETR, a figura do empregador rural por equiparação, aquele que habitual e profissionalmente, e por conta de terceiro, executa serviços agrários, mediante utilização de trabalho de outrem ${ }^{196}$. Não foi repetida a expressão "qualquer serviço", constante do antigo ETR. Agora o serviço praticado pelo empregador rural equiparado deve também ser agrário.

Há que se mencionar a Orientação Jurisprudencial n. ${ }^{\circ} 38$ da SDI -I do TST, caracterizando como rural o trabalhador de empresa de reflorestamento ${ }^{197}$.

Como visto, para classificar determinado empregado como rural conjugam-se dois elementos, o local da prestação de serviços, prédio rústico ou propriedade rural, e a pessoa contratante, o empregador rural. Dúvida pode surgir quando, apesar de o prédio ser rústico, ou a propriedade ser rural, o empregador exerce, preponderantemente, atividade não rural. Trata-se do conhecido exemplo das usinas de álcool e açúcar, cuja atividade preponderante é a transformação industrial da cana-de-açúcar, mas muitos dos seus trabalhadores se ativam na lavoura, em grandes extensões rurais, destinadas exclusivamente à agricultura. Evidentemente, a transformação industrial da cana-de-açúcar lhe altera a natureza e lhe retira a qualidade de matéria-prima.

O Tribunal Superior do Trabalho chegou a publicar o Enunciado n. ${ }^{\circ}$ 57, em 1974, afirmando não ser rural o trabalhador agrícola das usinas de açúcar: "Trabalhador rural. Os trabalhadores agrícolas das usinas de açúcar integram categoria profissional de industriários, beneficiando-se dos aumentos normativos obtidos pela referida categoria".

Em 1993 o Tribunal entendeu por bem cancelar o enunciado, por meio da

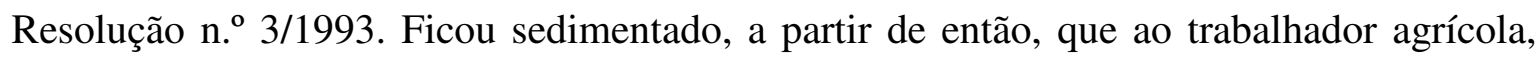
ligado ao cultivo da cana, aplica-se a lei n. ${ }^{\circ} 5.889 / 73$, mesmo sendo industrial e comercial a atividade preponderante do seu empregador (fabricar e vender açúcar e álcool).

Embora possa parecer exceção à regra segundo a qual a atividade econômica do empregador é o principal elemento a definir a condição rural do empregado, não se trata

\footnotetext{
${ }^{195}$ GARCIA, Gustavo Filipe Barbosa. op. cit., p. 240.

${ }^{196}$ Lei n. ${ }^{\circ} 5.889 / 73$, art. 40: "Equipara-se ao empregador rural a pessoa física ou jurídica que, habitualmente, em caráter profissional e por conta de terceiros, execute serviços de natureza agrária, mediante utilização do trabalho de outrem."

${ }^{197}$ OJ n. ${ }^{\circ} 38$, da SDI I do TST: empregado que exerce atividade rural. Empresa de reflorestamento. Prescrição própria do rurícola. (Lei n. ${ }^{\circ} 5.889 / 73$, art. 10, e Decreto n. $.^{\circ} 73.626 / 74$, art. $2^{\circ}, \S^{\circ}$ ).
} 
disso. Ocorre que a atividade econômica preponderante daquele que contrata o trabalhador não é o único critério para definir este como rural. Também é possível e necessário observar a questão a partir de um universo menor, circunscrito à relação entre o empregador e o trabalhador especificamente considerado.

A lei procura, entre as diversas atividades do empregador, identificar aquela exercida com a força de trabalho do empregado que se quer definir, como rural ou urbano. Passa a ser possível, assim, que o empregador possua duas facetas, uma como empregador rural, outra como empregador urbano, estando submetido à Lei n. $.^{\circ} 5.889 / 73$ e à CLT, respectivamente. Se em um mesmo prédio o empregador cultivar cana-de-açúcar e instalar sua usina industrial, terá as duas facetas nesse mesmo e único prédio. Nesse sentido, afirma José Otávio de Souza Ferreira ${ }^{198}$ :

"Em outras palavras, isso significa que no mesmo prédio rural,
trabalhando para o mesmo empregador, poderão subsistir trabalhadores
rurais e industriários, desde que os primeiros trabalhem em atividade
agroeconômica e os segundos em indústria que, operando a primeira
transformação do produto agrário, altere a sua natureza, retirando-lhe a
condição de matéria-prima. Neste caso, para a primeira atividade o
empregador é considerado rural, já para a segunda não."

A situação se dá não somente com usinas de açúcar e álcool, mas também com grandes indústrias de suco de laranja, possuidoras de extensas áreas agrícolas, de cultivo da fruta. O entendimento do cancelado Enunciado n. ${ }^{\circ} 57$ do TST não respeitava as condições fáticas, a realidade cotidiana dos que se ativam no cultivo e corte da cana-de-açúcar, não levava em conta a "realidade sociológica do habitat do trabalhador ${ }^{199 "}$ ". José Otávio de Souza Ferreira ${ }^{200}$, a respeito do referido Enunciado, afirma sua incoerência, exemplificando a situação de dois cortadores de cana, um registrado por determinada usina de açúcar, outro pela companhia agrícola do mesmo grupo econômico, com tratamentos jurídicos distintos.

O exemplo do autor evidencia grave afronta ao princípio constitucional da isonomia, pois estava a dispensar tratamento diferente a situações iguais. Com o cancelamento do Enunciado não mais há que se falar em tal afronta.

\footnotetext{
${ }^{198}$ FERREIRA, José Otávio de Souza. op. cit., p. 407.

${ }^{199}$ Expressão de: MAGANO, Octávio Bueno. op. cit., v. 2, p. 107.

${ }^{200}$ FERREIRA, José Otávio de Souza. op. cit., p. 405.
} 
Não há controvérsia no caso de a situação ser contrária, ou seja, a atividade preponderante do empregador ser rural e o trabalhador exercer tarefas em prédio não rústico e em propriedade urbana. Exemplifica-se o produtor rural que mantém empregados em seu escritório contábil na cidade. Tais empregados serão urbanos, regidos pela CLT, sem maiores dúvidas. A Lei n. ${ }^{\circ}$ 5.889/73 exige, para caracterizar o empregado como rural, a conjugação dos dois requisitos e, no exemplo dado, o local em que se presta serviço não autoriza a caracterização do empregado como rural ${ }^{201}$.

Em resumo, pode-se afirmar, hoje em dia, que o empregado rural é, antes de tudo, empregado, com os mesmos requisitos do empregado celetista. Será rural se estiverem preenchidas simultaneamente duas características, quais sejam, trabalhar para empregador rural e em prédio rústico ou propriedade rural. Prédio rústico é aquele cuja destinação é agroeconômica, independente da sua localização, e propriedade rural é a situada na zona rural. A lei define o que é empregador rural: "pessoa física ou jurídica, proprietário ou não, que explore atividade agroeconômica, em caráter permanente ou temporário, diretamente ou através de prepostos e com auxílio de empregados" ${ }^{202}$. Considera-se atividade agroeconômica não apenas a agricultura e a pecuária, mas também a exploração industrial rural, definida no artigo $2^{\circ}, \S 4^{\circ}$ do Regulamento das Relações Individuais e Coletivas de Trabalho Rural, aprovado pelo Decreto n. ${ }^{\circ}$ 73.626/74. A empregador rural está equiparada a "pessoa física ou jurídica que, habitualmente, em caráter profissional e por conta de terceiros, execute serviços de natureza agrária, mediante a utilização do trabalho de outrem" 203.

\footnotetext{
${ }^{201}$ A respeito do assunto Gustavo Filipe Barbosa Garcia esclarece: "Nessas circunstâncias, o melhor critério é diferenciar: os empregados que exercem suas funções no âmbito da atividade agroeconômica, considerados, assim, empregados rurais, dos empregados que laborem na atividade industrial não rural, considerados, assim, urbanos.

Tanto é assim que, se o referido empregador tivesse os seus estabelecimentos separados, deixando um para a atividade agroeconômica e outro, em local distinto, para a atividade de indústria urbana, os empregados do primeiro seriam rurais e os do segundo urbanos. A mesma conclusão não se altera pelo simples fato de as atividades distintas serem exercidas em espaços físicos situados no mesmo estabelecimento." GARCIA, Gustavo Filipe Barbosa. op. cit., p. 240.

${ }^{202}$ Art. $3^{\circ}$ da Lei n. ${ }^{\circ} 5.889 / 73$.

${ }^{203}$ Art. $4^{\circ}$ da Lei n. ${ }^{\circ} 5.889 / 73$.
} 


\subsection{Extensão da aplicação dos preceitos da Lei.$^{\circ}{ }^{5.889 / 73}$ aos trabalhadores rurais}

A Lei n. ${ }^{\circ}$ 5.889/73 estendeu aos trabalhadores rurais não empregados a aplicação de suas normas, desde que cabíveis:

Art. 17: as normas da presente Lei são aplicáveis, no que couber, aos trabalhadores rurais não compreendidos na definição do art. $2^{\circ}$, que prestem serviços a empregador rural.

Percebe-se a intenção do legislador de garantir um mínimo de proteção social aos trabalhadores rurais não empregados, estendendo-lhes os direitos trabalhistas cabíveis. Entretanto, não há na legislação critérios para se definir em que casos a extensão será, na prática, aplicável.

O Regulamento das Relações Individuais e Coletivas de Trabalho Rural, aprovado pelo Decreto n. 73.626/74, esclarece um pouco a questão, afirmando no seu artigo 14:

"As normas referentes à jornada de trabalho, trabalho noturno, trabalho do menor e outras compatíveis com a modalidade das respectivas atividades aplicam-se aos avulsos e outros trabalhadores rurais que, sem vínculo de emprego, prestam serviços a empregadores rurais."

Entretanto, a questão permanece em aberto, não havendo critérios objetivos para se determinar quais são as "outras normas compatíveis", nem quais são os "outros trabalhadores rurais". Caberá ao operador do direito, analisando o caso concreto, decidir quais normas aplicar, com grande insegurança jurídica. Percebe-se a mesma insegurança que havia com o Estatuto do Trabalhador Rural, quando havia divergência a respeito da identificação do sujeito protegido pela norma, que utilizava a expressão "trabalhador". Com a Lei n. ${ }^{\circ}$ 5.889/73 a expressão utilizada foi "empregado", mas quando estendeu os direitos aos trabalhadores não empregados, o fez sem definir critérios seguros e objetivos. Não se sabe, de antemão, quais são os direitos cabíveis, nem para quais tipos de trabalhadores.

Sobre o artigo 17 Amauri Mascaro Nascimento ${ }^{204}$ observa não se tratar de regra inédita no ordenamento jurídico pátrio. Antes, trata-se de reprodução do que já se aplicava anteriormente:

${ }^{204}$ NASCIMENTO, Amauri Mascaro. Visão global do direito do trabalho rural no Brasil, cit., p. 62. 
"Quanto ao âmbito das relações de trabalho rural há algo específico, porque a Lei do Trabalho Rural, no artigo 17, tem como sujeito trabalhador não só o empregado subordinado, mas outros trabalhadores também não enquadráveis no conceito de empregado. Isso se fez não por iniciativa dessa lei. Já era um critério anterior das leis passadas que se aplicavam a empregados e aos chamados volantes e aos chamados avulsos também, de modo que a Lei 5.889 apenas repetiu uma tradição legislativa no Brasil, como que a dar uma carta branca para que a jurisprudência se encarregasse, no que for compatível, de fazer uma exceção de direitos do empregado para outros tipos de trabalhadores rurais."

Cabe ressaltar que o referido artigo 17 não se destina ao contrato de trabalhado por pequeno prazo, previsto no artigo 14-A da Lei n. ${ }^{o} 5.889 / 73$, pois o trabalhador contratado sob tal regime é, em verdade, empregado rural, com todas as características próprias desse tipo de relação.

Vistas as linhas gerais da relação de trabalho rural, cabe agora a análise de alternativas que se apresentam, em tese, viáveis para que nelas se enquadre o trabalho rural de curta duração. 


\title{
3. TRABALHO AVULSO
}

\subsection{Justificativa}

Muito em função da lei n. ${ }^{\circ}$ 8.630/93, é comum associar-se trabalho avulso ao setor portuário, para movimentação de mercadorias. Entretanto, o modelo triangular não se restringe à orla marítima, havendo análises doutrinárias ${ }^{205}$ a respeito da possibilidade de sua aplicação no meio rural, para atividades não ligadas à movimentação de mercadorias. A necessidade de intensa mão de obra, por curto espaço de tempo, faz-se presente tanto na movimentação de mercadorias na zona portuária como nas atividades rurais. Justifica-se, assim, a abordagem do tema, analisando-se a viabilidade jurídica e prática da sua aplicação para o trabalho rural de curta duração.

\subsection{Antecedentes e evolução}

Segundo Amauri Mascaro Nascimento, o sistema de trabalho avulso surgiu espontaneamente na sociedade, não foi criação política, geração artificialmente engendrada pelo Direito. Nas suas palavras ${ }^{206}$ :

\begin{abstract}
"Assim, a modalidade de trabalho avulso, e mais especificamente, a movimentação de mercadorias em geral, não adveio de um processo artificial, como a criação de normas jurídicas ou a elaboração política de um modelo conveniente para a solução de algum problema prático, ela adveio naturalmente da realidade vivida por todas as partes envolvidas na movimentação de mercadorias. Não foi o trabalho avulso que invadiu as atividades portuárias e outras correlatas e sim essas atividades que culminaram no trabalho avulso como ele hoje existe."
\end{abstract}

\footnotetext{
${ }^{205}$ Podem ser citados, entre outros: COSTA E SILVA, Kataryna Just da. Consórcio de empregadores rurais: uma alternativa de contratação no meio rural na busca da dignidade do homem do campo. Revista do Tribunal Regional do Trabalho da $6^{a}$ Região, ano 1, n. 1, p. 125, 2001. ALVES, Francisco José da Costa; PAULILLO, Luiz Fernando. Sindicato dos trabalhadores avulsos: a agricultura paulista sai na frente, cit., p. 1048-1055. PELEGRINI, Mari Ângela. op. cit., p. 218 e ss. NASCIMENTO, Amauri Mascaro. O avulso não-portuário e o trabalho rural. In: GIORDANI, Francisco Alberto da Motta Peixoto; MARTINS, Melchíades Rodrigues; VIDOTTI, Tarcio José (Coords.). Direito do trabalho rural: homenagem a Irany Ferrari. 2. ed. São Paulo. LTr, 2005. p. 155-178.

${ }^{206}$ Id. Ibid., p. 159.
} 
Inicialmente vinculado ao transporte aquaviário, por ser este o primeiro utilizado para comércio pela humanidade, o sistema de trabalho avulso se disseminou pelos outros meios de transporte à medida que estes se desenvolveram ${ }^{207}$.

No Brasil, aponta Ubiracy Torres Cuóco ${ }^{208}$, o trabalho avulso também teve seu início na região portuária, ganhando as demais regiões com o desenvolvimento da economia, principalmente com os engenhos e plantações ${ }^{209}$.

Segundo Alice Monteiro de $\operatorname{Barros}^{210}$, o ordenamento jurídico pátrio definiu trabalhador avulso, pela primeira vez, através do Decreto n. ${ }^{\circ} 1.577$, de 08 de abril de 1937. Eram avulsos os associados aos sindicatos, destacados por estes para prestar serviços de natureza temporária a trapicheiros e armazéns. Percebe-se, já naquela época, a intermediação sindical como característica marcante do trabalho avulso ${ }^{211}$.

Ubiracy Torres Cuóco ${ }^{212}$ lembra os hoje revogados artigos 257 e 266 , $\S 1^{\circ}$ da $\mathrm{CLT}^{213}$, já mencionando a intermediação sindical, bem como o artigo 285, alínea "c" da $\mathrm{CLT}^{214}$, abrindo caminho para o trabalho avulso fora da área do porto.

\footnotetext{
${ }^{207}$ Nas palavras de Amauri Mascaro Nascimento: "Historicamente, o trabalho de carga e descarga e movimentação de mercadorias em geral são antigos conhecidos da sociedade. Surgiram num primeiro momento como o transporte aquaviário, o primeiro a ser utilizado comercialmente pela humanidade e acompanharam toda a evolução dos sistemas de transporte de mercadorias ao longo da história e nas mais diversas sociedades à medida que o comércio se desenvolvia e a quantidade de bens a serem transportados crescia." NASCIMENTO, Amauri Mascaro. O avulso não-portuário e o trabalho rural, cit., p. 159.

${ }^{208}$ CUÓCO, Ubiracy Torres. Trabalhadores avulsos. Revista LTr, São Paulo, ano 70, n. 4. p. 477, abr. 2006.

${ }^{209}$ Nas palavras de Amauri Mascaro Nascimento: "No Brasil, a organização da atividade dos movimentadores de mercadoria ganhou, num primeiro momento, maior ênfase no âmbito portuário, mas logo o trabalho lá desenvolvido espalhou-se pelo país com o desenvolvimento dos engenhos e das plantações e, ainda hoje, permanece intenso e se faz necessário tanto no porto como fora dele." NASCIMENTO, Amauri Mascaro. O avulso não-portuário e o trabalho rural, cit., p. 159.

${ }^{210}$ BARROS, Alice Monteiro de. Curso de direito do trabalho, cit., p. 174.

${ }^{211}$ Amauri Mascaro Nascimento aponta: "Com efeito, o regime de trabalho nos portos brasileiros caracterizou-se, através do tempo, basicamente pela intermediação de um terceiro entre as diversas categorias de trabalhadores e os tomadores de serviços, o próprio sindicato das diversas categorias de trabalhadores denominados avulsos." NASCIMENTO, Amauri Mascaro. O novo conceito de trabalhador avulso. Trabalho e Doutrina: processo jurisprudência, São Paulo, n. 19, p. 3, dez. 1998.

${ }^{212}$ CUÓCO, Ubiracy Torres. op. cit., p. 477.

${ }^{213}$ Art. 257: A mão de obra na estiva das embarcações, definida na alínea "a" do art. 255 só poderá ser executada por operários estivadores ou por trabalhadores em estiva de minérios nos portos onde os houver especializados, de preferência sindicalizados, devidamente matriculados nas Capitanias dos Portos ou em suas Delegacias ou Agências, exceto nos casos previstos no artigo 260 desta Seção.

Art. 266, § $1^{\circ}$ : Sendo os serviços executados por operários sindicalizados, organizarão os respectivos sindicatos os rodízios de operários, para que o trabalho caiba, equitativamente a todos.

${ }^{214}$ Art. 285: (...) c) ao sindicato definido na letra " $b$ " anterior, compete:(...)

2) exercer a atividade definida no citado art. 285, itens I e II e respectivas alíneas, nos portos não organizados e nos armazéns, depósitos, trapiches, veículos de tração animal ou mecânica, vagões, etc., em quaisquer locais em que as mercadorias tenham sido recebidas, entregues, arrumadas ou beneficiadas, e, bem assim, lingar ou deslingar as que necessitarem de auxílio de guindastes ou de outros aparelhos mecânicos, nas empresas, firmas, sociedades ou companhias particulares; ”
} 
Posteriormente, a Lei n. ${ }^{\circ}$ 3.807/60 (Lei Orgânica da Previdência Social - LOPS), no seu artigo $4^{\circ}$, letra "c", conceituou trabalhador avulso como aquele que presta serviços a diversas empresas, agrupado, ou não, em sindicato, inclusive os estivadores, conferentes e assemelhados. A diferença entre trabalhador "agrupado" ou "não agrupado" foi explicada por José Martins Catharino ${ }^{215}$, para quem agrupado seria o avulso associado ao sindicato, a quem caberia selecionar e dirigir os trabalhadores para atender à requisição feita pelo tomador. Avulso não agrupado seria o trabalhador individual, não intermediado por sindicato, podendo ser considerado, eventual ou até mesmo empregado, dependendo das circunstâncias fáticas.

Percebe-se na LOPS a referência expressa aos serviços portuários, demonstrando-se a força política dessa classe trabalhadora. De fato, até chegar à equiparação de direitos com os empregados, promovida pela Constituição da República de 1988, os trabalhadores avulsos foram conquistando uma série de direitos ${ }^{216}$, como décimo-terceiro salário e FGTS, (Lei n. ${ }^{\circ}$ 5.480/68), repouso semanal remunerado (art. $3^{\circ}$ da Lei n. ${ }^{\circ}$ 605/49), saláriofamília (Decreto n. ${ }^{o}$ 53.153/63), férias (Decreto n. ${ }^{\circ}$ 61.851/67), abono do PIS (Lei Complementar n. ${ }^{\mathrm{o}}$ 7/70).

Desde 1993 há lei específica para o trabalho portuário (Lei n. ${ }^{\circ}$ 8.630/93), sendo que somente em 2009, mais de quinze anos depois, foi editada a lei sobre os demais trabalhadores avulsos (Lei n. ${ }^{\circ}$ 12.023/09). A diferença de reconhecimento jurídico entre os trabalhadores portuários e os demais avulsos foi apontada por Amauri Mascaro Nascimento ${ }^{217}$ em 2005, antes, portanto, da lei de 2009:

\footnotetext{
"No âmbito portuário, o trabalho avulso é amplamente reconhecido e conta com legislação específica que garante sua definição e proteção. Já o trabalho avulso fora da área portuária ainda é parcialmente negligenciado pela legislação trabalhista e objeto de muita discussão doutrinária e jurisprudencial".
}

Essa discrepância legislativa entre os portuários e não portuários, possivelmente oriunda da capacidade singular de organização e mobilização da classe portuária, teve como pano de fundo as peculiaridades do trabalho na orla marítima, especialmente a concentração das atividades em um único local, o porto. Para lá convergiam e convergem, obrigatoriamente, todos aqueles que demandam a mão de obra, dependendo

\footnotetext{
${ }^{215}$ CATHARINO, José Martins. op. cit., v. 1, p. 187.

${ }^{216}$ MARTINS, Sergio Pinto. Direito do trabalho, cit., p. 169.

${ }^{217}$ NASCIMENTO, Amauri Mascaro. O avulso não-portuário e o trabalho rural, cit., p. 159.
} 
exclusivamente dos trabalhadores que lá se propõem a fornecer sua força de trabalho. No mesmo lugar se fazem presentes todos os trabalhadores envolvidos, reconhecendo-se nas mesmas condições de trabalho, com os mesmos interesses e aspirações. Explica-se, assim, a capacidade particularmente fortalecida de organização, mobilização e negociação dos trabalhadores portuários, se comparados aos demais movimentadores de mercadorias, difusamente espalhados em armazéns e estações.

As condições materiais da atividade ajudam a justificar, portanto, a divisão proposta por Amauri Mascaro Nascimento entre trabalhadores avulsos portuários e não portuários $^{218}$, embora a Constituição da República de 1988 não tenha observado diferenciação alguma ao garantir aos trabalhadores avulsos, todos eles, os mesmos direitos dos empregados.

\subsection{Identificação da figura contratual}

A relação de trabalho avulso é triangular, envolve o trabalhador, o beneficiário dos serviços prestados, chamado tomador dos serviços, e um agente intermediador, sindicato profissional ou Órgão Gestor de Mão de Obra (OGMO), na região portuária. O tomador dos serviços não contrata diretamente o trabalhador, requisita a mão de obra ao agente intermediador, que a fornece de acordo com escala de revezamento previamente elaborada. O pagamento é feito ao intermediador, responsável por efetuar o rateio entre os trabalhadores, que atuam por pequenos períodos para cada tomador. Em função desse curto período e do caráter intermitente da prestação dos serviços, alguns doutrinadores entendem se tratar de espécie de trabalho eventual ${ }^{219}$. Octávio Bueno Magano ${ }^{220}$, em 1992, antes da legislação atual, considerou serem sinônimas as expressões "trabalhador avulso" e

\footnotetext{
${ }^{218}$ NASCIMENTO, Amauri Mascaro. O avulso não-portuário e o trabalho rural, cit., p. 158.

219" O obreiro chamado avulso corresponde a modalidade de trabalhador eventual, que oferta sua força de trabalho, por curtos períodos de tempo, a distintos tomadores, sem se fixar especificamente a qualquer deles. $O$ que distingue o avulso do eventual, entretanto, é a circunstância de sua força de trabalho ser ofertada, no mercado específico em que atua (setor portuário), através de uma entidade intermediária." DELGADO, Maurício Godinho. op. cit., p. 341.

220 "O trabalhador avulso é o próprio trabalhador eventual. As expressões, aliás, são sinônimas, pois que avulso é desirmanado, o pertencente a uma coleção não completa. (...) Contudo, na técnica legislativa brasileira, desenvolveu-se a tendência de se usar da expressão eventual para designar genericamente o trabalhador transitório e do termo avulso para indicar a sua filiação à Previdência Social. (...) É verdade que a Previdência não se estendeu, desde logo, a todo tipo de trabalhador eventual, mas apenas àquele cuja atividade se desenvolvia mediante intermediação do sindicato.”. MAGANO, Octávio Bueno. Manual de direito do trabalho: direito individual do trabalho. 3. ed. São Paulo: LTr. 1993. v. 2, p. 151-152.
} 
"trabalhador eventual", com a observação de que a legislação previdenciária passou a chamar de avulso o trabalhador intermediado pelo sindicato, dando-lhe proteção, em oposição ao trabalhador eventual não intermediado, desprotegido.

Hoje em dia prevalece o entendimento de que trabalhador avulso não se equipara a trabalhador eventual. ${ }^{221}$. Sérgio Pinto Martins ${ }^{222}$ aponta, atualmente, as semelhanças e diferenças entre as duas espécies de trabalhadores:

"O avulso é uma espécie de trabalhador eventual, pois presta serviços
esporádicos ao mesmo tomador dos serviços. Distingue-se, porém, o
avulso do trabalhador eventual, pois o primeiro tem todos os direitos
previstos na legislação trabalhista, enquanto o eventual só tem direito ao
preço avençado no contrato e à multa pelo inadimplemento do pacto,
quando for o caso. O avulso é arregimentado pelo sindicato, enquanto o
eventual não tem essa característica."

A movimentação de mercadorias, para empresas que o fazem com frequência, não é atividade eventual, extraordinária. Para essas empresas, tanto as eminentemente transportadoras, como para as produtoras ou que comercializam produtos, a movimentação de mercadorias é algo que, embora possa ser intermitente, não deixa de ser rotineiro. Nesse diapasão, não se poderia considerar o trabalhador avulso como espécie de eventual, pois o critério da eventualidade não se determina unicamente pela quantidade de tempo em que o trabalhador emprega sua força de trabalho para determinado beneficiário, mas também, e principalmente, pela inserção da tarefa executada nas atividades normais, ainda que intermitentes, da empresa ${ }^{223}$.

Em verdade, para a caracterização do trabalho avulso pouco importa se a atividade está inserida na rotina do tomador ou se foi uma única vez em que este, por motivo fortuito, teve de movimentar mercadorias, teve de se utilizar da mão de obra avulsa. Ou seja, o trabalho avulso, com relação ao tomador dos serviços, pode se dar tanto em caráter eventual como rotineiro. Como dito acima, o que caracteriza o trabalho avulso é a presença do agente intermediador, que cadastra os trabalhadores da sua região, realiza escala de revezamento e os distribui entre os diversos tomadores. Estes efetuam o pagamento global

\footnotetext{
${ }^{221}$ Entre outros, cita-se: Amauri Mascaro Nascimento: "O vocábulo 'trabalhador avulso' é utilizado, por alguns, com a significação de trabalhador eventual. Porém, não é exatamente esse o seu sentido." NASCIMENTO, Amauri Mascaro. Curso de direito do trabalho. 24. ed., cit., p. 864. E Gustavo Filippe Barbosa Garcia: "No entanto, em razão das diversas peculiaridades envolvendo o trabalho avulso, pode-se dizer que ele, na realidade, se distingue do mero trabalhador eventual” GARCIA, Gustavo Filipe Barbosa. op. cit., p. 271.

${ }^{222}$ MARTINS, Sergio Pinto. Direito do trabalho, cit., p. 168.

${ }^{223}$ Sobre trabalhador eventual, ver acima, fls. 44 e ss.
} 
pelo serviço prestado ao agente intermediador, que promove o rateio do valor entre os obreiros. As tarefas são de curta duração para cada tomador, não havendo vínculo empregatício com o tomador nem com o intermediário, quer porque não se fazem presentes os requisitos empregatícios, quer porque a lei expressamente veda essa possibilidade.

Essas são, em linhas gerais, as características do trabalho avulso, resumidas por Sérgio Pinto Martins ${ }^{224}$ da seguinte forma: a) liberdade na prestação dos serviços, não havendo vínculo com o sindicato ou com os tomadores de serviço; b) possibilidade de prestação de serviço a mais de uma empresa; c) intermediação do Órgão Gestor de Mão de Obra - OGMO ou do sindicato, que cobram pelo serviço prestado, incluídos os encargos, fazendo o rateio entre os trabalhadores; d) o trabalhador permanece por curto período trabalhando para cada tomador.

Tais características também são observadas por Amauri Mascaro Nascimento ${ }^{225}$ :

\begin{abstract}
"Assim, as notas características do trabalho avulso são: a) a intermediação do sindicato do trabalhador na colocação da mão de obra, hoje não mais obrigatória; b) a curta duração dos serviços prestados a um beneficiado; c) a remuneração paga basicamente em forma de rateio procedido pelo sindicato".
\end{abstract}

De maneira mais aprofundada, Ubiracy Torres $\mathrm{Cuóco}^{226}$ elenca seis elementos que tipificam o trabalhador avulso, quais sejam: 1) inexistência de vínculo empregatício; 2) sindicalização não obrigatória, devendo o sindicato intermediador incluir todos os trabalhadores no rodízio, inclusive os não sindicalizados; 3) prestação de serviços urbanos ou rurais; 4) pouca duração dos serviços, o que não se confunde com eventualidade. $O$ autor utiliza como exemplo a tarefa de colheita de produtos rurais, indicando de modo correto que o tipo de atividade, comumente ligada à movimentação de mercadorias, não é fator determinante; 5) falta de pessoalidade - não é importante para o trabalhador saber quem é o beneficiário da sua força de trabalho, ele apenas exerce sua atividade conforme o intermediador lhe indica; e vice-versa, ou seja, o tomador dos serviços se interessa apenas

\footnotetext{
${ }^{224}$ MARTINS, Sergio Pinto. Direito do trabalho, cit., p. 168-169.

${ }^{225}$ NASCIMENTO, Amauri Mascaro. Curso de direito do trabalho. 24. ed., cit., p. 864.

${ }^{226} \mathrm{O}$ autor destaca, também, as diferenças e semelhanças entre trabalhador avulso e empregado: “1) Eventualidade e pouca duração dos serviços prestados; 2) Não ocorrência de subordinação jurídica ao tomador dos serviços; 3) a retribuição devida ao operário é paga pelo sindicato e não pelo tomador dos serviços; 4) prestação dos serviços a diversos tomadores, não se podendo prever a duração de cada um, sendo desnecessário que o operário saiba quais são os tomadores (ao operário cabe prestar serviços que foram contratados pelo sindicato, sem necessidade de saber quais os proprietários das mercadorias)." CUÓCO, Ubiracy Torres. op. cit., p. 475-483.
} 
pelo resultado, não lhe importando quem presta diretamente os serviços - e 6) intermediação sindical, ao que se deve acrescentar, após a Lei n. ${ }^{\circ}$ 8.630/93, a possibilidade de intermediação pelo OGMO.

Quanto à subordinação, não há lei estabelecendo a sujeição do trabalhador às ordens do tomador dos serviços. Sérgio Pinto Martins ${ }^{227}$ afirma não haver subordinação ao tomador nem ao intermediário, podendo o trabalhador ser substituído, o que descaracteriza a pessoalidade também.

Entretanto, o trabalhador avulso não exerce suas tarefas de maneira autônoma, livre de quaisquer orientações. Segundo Ubiracy Torres Cuóco ${ }^{228}$, o horário é predeterminado pelo tomador dos serviços, cabendo ao agente intermediador dirigir a atividade, exercendo o "comando na prestação dos serviços (...) orientação e controle." O art. 19 da Lei n. ${ }^{\circ}$ 8.630/93 concede ao Órgão Gestor de Mão de Obra poder disciplinar, com atribuição de aplicar repreensão verbal ou escrita, suspensão e até cancelamento do registro. Percebe-se que, apesar do avulso não se vincular ao tomador dos serviços, e do sindicato não poder ser considerado empregador, há um determinado grau de subordinação do trabalhador, que não se apresenta senhor absoluto do próprio modo de proceder. Nas palavras de Nelson Mannrich $^{229}$, há “subordinação atípica."

\subsection{Bases normativas e principais características}

Como visto, os trabalhadores avulsos portuários gozam da regulação específica da Lei n. ${ }^{\circ}$ 8.630, de 25 de fevereiro de 1993, que dispõe sobre o regime jurídico da exploração dos portos organizados e das instalações portuárias, e dá outras providências, e Lei n. ${ }^{\circ}$ 9.719, de 27 de novembro de 1998, que dispõe sobre normas e condições gerais

\footnotetext{
${ }^{227}$ Nas palavras do autor: "Não é o trabalhador avulso subordinado nem à pessoa a quem presta serviços, muito menos ao sindicato, que apenas arregimenta a mão de obra e paga os prestadores de serviço, de acordo com o valor recebido das empresas. $O$ avulso não presta serviços com pessoalidade, pois o trabalhador pode ser substituído por outra pessoa. Ao tomador não interessa normalmente que o serviço seja feito por determinada e específica pessoa, mas que o trabalho seja realizado. Pouco importa quem irá fazer o trabalho. a relação, portanto, não é intuitu personae". MARTINS, Sergio Pinto. Direito do trabalho, cit., p. 168.

${ }^{228}$ CUÓCO, Ubiracy Torres. op. cit., p. 480-481.

${ }^{229}$ MANNRICH, Nelson. Alternativas para o trabalho rural. Revista IMES - Direito: revista do Curso de Direito do Centro Universitário Municipal de São Caetano do Sul, São Caetano do Sul, v. 1, n. 2, p. 37, jan./jun. 2001.
} 
de proteção ao trabalho portuário, institui multas pela inobservância de seus preceitos $e$ dá outras providências.

Diversas são as regras relativas à prestação de serviço dos trabalhadores portuários, destacando-se as relativas ao Órgão Gestor de Mão de Obra (OGMO) e suas atribuições. A legislação afastou a exclusividade do sindicato como intermediador, passando a tarefa ao OGMO, constituído, em cada porto, pelo Operador Portuário.

Ao OGMO cabem diversas tarefas e atribuições, elencadas no artigo 18 da Lei . $^{\circ}$ 8.630/93, como a administração do fornecimento da mão de obra, a manutenção de cadastro e registro dos trabalhadores, a expedição de documento de identificação dos trabalhadores, entre outros. O artigo 19 da referida lei dá ao OGMO poder disciplinar sobre os trabalhadores, impondo-lhe o dever de zelar pelas normas de segurança e saúde dos trabalhadores e a responsabilidade solidária, com os operadores portuários, pela remuneração devida aos trabalhadores. O artigo 20 esclarece não haver vínculo empregatício entre os trabalhadores e o OGMO.

De maior interesse para o presente estudo são os trabalhadores não portuários, submetidos a condições materiais não verificadas nos portos. Segundo Amauri Mascaro Nascimento $^{230}$, a participação sindical se encontra também nas raízes do trabalho avulso não portuário, representando maior segurança para tomadores de serviço, trabalhadores e governo:

"E como fora da área de porto havia também trabalho semelhante, a despeito de ter características próprias, começaram a surgir seus primeiros operários, a princípio tidos como 'eventuais' e, depois, organizados em sindicatos. À semelhança dos portuários, foram considerados trabalhadores avulsos, operando sempre intermediados pelos respectivos sindicatos, como forma de assegurar melhor os direitos dos trabalhadores, e, simultaneamente, evitar possível argüição de vinculação de emprego.

A intermediação dos sindicatos, tal como ocorrente na área de porto, representava certa garantia para os tomadores dos serviços, para os operários e para o próprio Governo.”

Em agosto de 1988 os trabalhadores avulsos não portuários passaram a compor a categoria profissional diferenciada de "trabalhadores na movimentação de mercadorias em

\footnotetext{
${ }^{230}$ NASCIMENTO, Amauri Mascaro. O avulso não-portuário e o trabalho rural, cit., p. 160.
} 
geral" ${ }^{231}$. Mais de vinte anos mais tarde a Lei n. ${ }^{\circ} 12.023$, de 27 de agosto de 2009, trouxe regras sobre a atuação desses trabalhadores, com disposições sobre "atividades de movimentação de mercadorias em geral e sobre trabalho avulso".

Logo em seu artigo $1^{\circ}$, a Lei n. ${ }^{\circ}$ 12.023/09 traz a obrigatoriedade da intermediação do sindicato da categoria, por meio de acordo ou convenção coletiva de trabalho. Há também a descrição de atividades consideradas movimentação de mercadorias, incluindose as preparatórias, como limpeza nos locais necessários à viabilidade das operações. No rastro da Lei n. ${ }^{\circ}$ 12.023/09, a Receita Federal do Brasil editou a Instrução Normativa n. ${ }^{\circ}$ 971, lembrada por Gustavo Fillipe Barbosa Garcia ${ }^{232}$, definindo nos mesmos moldes o trabalhador avulso.

Da mesma maneira que a Lei 8.630/93, a Lei n. ${ }^{\circ}$ 12.023/09 afirma a possibilidade de realização das atividades por trabalhadores avulsos ou com vínculo empregatício.

Ao sindicato intermediador a lei previu tarefas a cumprir, como elaborar escala de trabalho, folha de pagamento, e garantir informação aos trabalhadores ${ }^{233}$. Previu também deveres $^{234}$, como promover publicidade das escalas, rodízio entre os trabalhadores, equilíbrio entre os filiados ao sindicato e os não filiados, entre outros. São solidária e pessoalmente responsáveis os dirigentes da entidade sindical caso o valor da remuneração dos trabalhadores avulsos não seja repassado dentro do prazo de 72 horas, e a identidade de cadastro para a escalação não poderá permitir a distinção entre sindicalizados e não sindicalizados, para efeito de acesso ao trabalho.

Ao tomador dos serviços ${ }^{235}$ cabe pagar ao sindicato o valor correspondente aos direitos remuneratórios dos trabalhadores, no prazo de 72 horas a partir do encerramento do trabalho requisitado, e o recolhimento de FGTS e encargos sociais e previdenciários, nos prazos legais, além de responder solidariamente pela efetiva remuneração do trabalho prestado, na medida da utilização da mão de obra. De maneira coerente, a lei determina o dever do agente intermediador de apresentar documentos que comprovem o rateio, aos

\footnotetext{
${ }^{231}$ Amauri Mascaro Nascimento pontua: "A atividade de movimentação de mercadorias e de cargas sempre teve importância na economia brasileira, de modo que, em agosto de 1988, foi contemplada como categoria profissional diferenciada pela extinta Comissão de Enquadramento Sindical (art. 577, da CLT), que tratava do quadro específico de atividades e profissões, mediante ato administrativo de 1987(Portaria 3.176)e Resolução da Comissão de Enquadramento Sindical ( Portaria 3.204)”. NASCIMENTO, Amauri Mascaro. Movimentadores de mercadoria como categoria diferenciada: a análise da movimentação de cargas e mercadorias. Disponível em: http://www.nucleomascaro.com.br/blog/?p=18>. Acesso em: 25 nov. 2011.

${ }^{232}$ GARCIA, Gustavo Filipe Barbosa. op. cit., p. 273.

${ }^{233}$ Art. $4^{-}$

${ }^{234}$ Art. $5^{-}$

${ }^{235}$ Arts. $6^{\circ}$ e $7^{\circ}$.
} 
tomadores. Estes devem zelar, também, pelo cumprimento das normas de segurança e saúde, sendo responsáveis pela entrega dos equipamentos de proteção individual.

Atualmente, portanto, há duas leis prevendo a utilização de trabalho avulso, uma voltada às atividades portuárias, com intermediação do OGMO (Lei n. ${ }^{0}$ 8.630/93), e outra voltada à movimentação de mercadorias em áreas não portuárias, com a intermediação do sindicato profissional (Lei n. ${ }^{0}$ 12.023/09). Nota-se a menção expressa, em ambos os diplomas, à exclusão do vínculo empregatício. Trabalhador avulso não é empregado não apenas porque não estão presentes os requisitos próprios, mas também por expressa disposição legal.

Por óbvio prevalece, também no caso do trabalhador avulso, o Princípio da Primazia da Realidade sobre a Forma, devendo ser reconhecido o vínculo empregatício se, na realidade, estiverem presentes os requisitos próprios, embora sob a ilegítima máscara formal do trabalho avulso.

Importa relatar a controvérsia existente a respeito da constitucionalidade da intermediação da mão de obra pelo sindicato. Para alguns, a intermediação obrigatória do sindicato seria incompatível com a liberdade de associação e de filiação sindical, previstas respectivamente no artigo $5^{\circ}$, inciso $\mathrm{XX}$ e artigo $8^{\circ}$, inciso $\mathrm{V}$ da Constituição da República. Ademais, a função precípua dos sindicatos, de negociação, representação e defesa dos interesses e direitos dos trabalhadores, restaria inconciliável com a de intermediação de mão de obra ${ }^{236}$. Afastar o sindicato da intermediação equivale a afirmar a necessidade de se criar um órgão para realizar tal tarefa. Não cabe ao presente estudo aprofundar o debate acerca da aventada inconstitucionalidade da participação sindical no fornecimento de mão de obra, sob pena de se distanciar demasiadamente do tema. Importa analisar a aplicabilidade do sistema de trabalho avulso para as atividades rurais de curta duração, seja com intermediação do sindicato ou de outro órgão criado para esse fim. De qualquer maneira, como aponta Mari Ângela Pelegrini ${ }^{237}$, os sindicatos de trabalhadores rurais, hoje em dia, não estão preparados para a nova atribuição.

\footnotetext{
${ }^{236}$ Nesse sentido, entre outros, SOUZA, Fernanda Amabile Marinho de. A inconstitucionalidade da atuação sindical na Lei n. ${ }^{\circ}$ 12.023/2009. Revista Síntese Trabalhista e Previdenciária, Brasília, ano 22, n. 259, p. 71-82, jan. 2011.

${ }^{237}$ PELEGRINI, Mari Ângela. op. cit., p. 218 e ss.
} 


\subsection{Trabalho avulso para serviços rurais não ligados à movimentação de mercadoria - viabilidade jurídica}

Para tratar da possível aplicação do modelo avulso no meio rural e, mais que isso, nas atividades rurais, diversas da movimentação de mercadorias, é salutar partir da definição apresentada por Sérgio Pinto Martins ${ }^{238}$ para trabalhador avulso: "Pessoa física que presta serviço sem vínculo empregatício, de natureza urbana ou rural, a diversas pessoas, sendo sindicalizado ou não, com intermediação obrigatória do sindicato da categoria profissional ou do órgão gestor de mão de obra."

Cabe observar, no conceito acima, não haver menção aos serviços prestados pelos trabalhadores. De fato, o modelo de relação de trabalho não se define a partir disso, pois as tarefas executadas pelos trabalhadores avulsos, portuários ou não, podem ser realizadas por empregados também, conforme previsão expressa das leis n. ${ }^{\circ} 8.630 / 93$ e 12.023/09 ${ }^{239}$.

De fato, a característica marcante do trabalho avulso, independentemente dos serviços prestados, é a relação triangular, sem vínculo empregatício ${ }^{240}$, com a constante troca em uma das pontas do triângulo, a correspondente ao tomador dos serviços ${ }^{241}$.

A atual Lei de Custeio da Seguridade Social (Lei n. ${ }^{\circ} 8.212 / 91$ ), inclui no conceito de trabalhador avulso, equivocadamente, o serviço por ele executado, a ser definido no respectivo regulamento. Segundo o seu artigo 12, inciso VI, trabalhador avulso é a pessoa física que "presta a diversas empresas, sem vínculo empregatício, serviços de natureza urbana ou rural definidos no regulamento”.

\footnotetext{
${ }^{238}$ MARTINS, Sergio Pinto. Direito do trabalho, cit., p. 168.

${ }^{239}$ Artigo 26 da lei 8.630/93 e artigo $3^{\circ}$ da Lei n. ${ }^{\circ} 12023 / 09$.

${ }^{240}$ Nesse sentido, Amauri Mascaro Nascimento: "Logo, não será pela função exercida, mas através do modo como é prestada, que o conceito poderá ser aclarado e nesse particular é que ganham destaque os já mencionados requisitos da intermediação e da inexistência da relação de emprego, dados que são, efetivamente, indicativos da separação entre os dois tipos de trabalho, o do empregado e o do avulso.". NASCIMENTO, Amauri Mascaro. O novo conceito de trabalhador avulso, cit., p. 6.

${ }^{241}$ Assim leciona Roque Jurandy de Andrade Junior: "A relação de trabalho avulso é triangular, nela atuando o tomador de serviços, o intermediário na contratação e o trabalhador. Por conseqüência, a conceituação dessa espécie de trabalhador está assentada em três características essenciais, a saber: a) prestação de serviços de curta duração para várias empresas; b) intermediação da mão-de-obra pelo sindicato de classe ou pelo órgão gestor de mão-de-obra-OGMO e c) ausência de vínculo empregatício." ANDRADE JÚNIOR, Roque Jurandy. Efeitos da isonomia jurídica entre os trabalhadores portuários avulsos e os com vínculo de emprego na duração do trabalho. $L T r$ : suplemento trabalhista, São Paulo, v. 43, n. 31, p. 143, 2007.
} 
No mesmo ano foi aprovado o Regulamento da Organização e do Custeio da Seguridade Social, pelo Decreto n. 356 , de 07 de dezembro de 1991, afirmando ser avulso:

\footnotetext{
"aquele que, sindicalizado ou não, presta serviço de natureza urbana ou rural, sem vínculo empregatício, a diversas empresas, com intermediação obrigatória do sindicato da categoria, assim considerados:

a) o estivador, inclusive o trabalhador de estiva em carvão e minério;

b) o trabalhador em alvarenga;

c) o conferente de carga e descarga;

(...)

q) outros assim classificados pelo Ministério do trabalho e Previdência Social.
}

A Lei deixou o conceito aberto, esperando do regulamento a definição dos serviços que caracterizariam o trabalho avulso. O Decreto mencionou apenas que os serviços podiam ser de natureza urbana ou rural, trazendo uma lista exemplificativa de funções passíveis de serem exercidas por trabalhadores avulsos. A alínea "q" não deixou dúvidas, tratava-se de rol meramente exemplificativo.

Nesses moldes a Lei teve seu conteúdo preenchido, devendo se reconhecer que o sistema de relação avulsa podia se aplicar em quaisquer atividades, urbanas ou rurais.

Posteriormente, o Decreto n. ${ }^{\circ} 356 / 91$ foi revogado pelo Decreto n. ${ }^{\circ}$ 612/92, que aprovou novo Regulamento, repetindo a definição de trabalhador avulso, inclusive a alínea indicativa do caráter meramente exemplificativo da enumeração. Percebe-se que a exigência da intermediação pelo sindicato não constava da Lei 8.212/91, apenas do respectivo Regulamento, que extrapolou sua margem de ação, pois a ele estava destinada apenas a definição dos serviços, de natureza urbana ou rural ${ }^{242}$.

Após a edição da Lei n. ${ }^{\circ}$ 8.630/93, criadora da figura do OGMO, o Decreto n. ${ }^{\circ}$ 2.173, de 05 de março de 1997 aprovou novo Regulamento da Organização e do Custeio da Seguridade Social, introduzindo na definição do trabalhador avulso a previsão da intermediação não só do sindicato, mas do OGMO, nos termos da Lei no 8.630, de 25 de

\footnotetext{
${ }^{242}$ A observação é de Alice Monteiro de Barros: “O mesmo regulamento (Decreto $n .{ }^{\circ}$ 612), ao definir o trabalhador avulso, afirma que ele deverá prestar esses serviços a várias empresas, com intermediação obrigatória do sindicato da categoria. O regulamento invade a reserva legal, pois a Lei n. 8.212, de 1991, não estabelece a obrigatoriedade de intermediação do sindicato e, se não bastasse, esta foi abolida dos trabalhos portuários, como se infere da Lei $n^{\circ}{ }^{\circ} 8.630 / 93$, sendo a entidade sindical substituída pelo Órgão Gestor de Mão de Obra (OGMO).” BARROS, Alice Monteiro de. Curso de direito do trabalho, cit., p. 174.
} 
fevereiro de 1993. Da mesma maneira que vinha sendo adotada, o novo Regulamento trouxe um rol de trabalhadores considerados avulsos, apresentando, novamente, alínea denunciadora da condição meramente exemplificativa do rol.

Em 1999 foi editado novo Regulamento da Previdência Social, vigente até os dias atuais, aprovado pelo Decreto n. ${ }^{\circ} 3.048 / 99$. O atual Regulamento, repetindo o que havia anteriormente, mencionou apenas "serviços de natureza urbana ou rural", mantendo a ampla liberdade ${ }^{243}$. Trouxe também a enumeração de trabalhadores considerados avulsos, sem, contudo, a regra anteriormente existente segundo a qual seriam também avulsos outros trabalhadores, "assim classificados pelo Ministério do Trabalho e Previdência Social”.

A supressão dessa alínea não pode ser entendida como transformação do rol, anteriormente exemplificativo, em taxativo. Ao contrário, a supressão da alínea significa apenas que outros trabalhadores também podem ser considerados avulsos, mesmo sem classificação prévia do Ministério do Trabalho. Dispensou-se a classificação Ministerial, abrindo-se ainda mais o conceito, com maior liberdade nas relações de trabalho.

Mari Ângela Pelegrini ${ }^{244}$ observa que apesar de o inciso VI do artigo $9^{\circ}$ do Decreto n. 3.048/99 mencionar serviços de natureza urbana e rural, não há, nas alíneas, atividade rural alguma na enumeração. Isso seria suficiente para demonstrar se tratar de rol meramente exemplificativo. Há que se observar, no entanto, que da enumeração consta o “ensacador de café, cacau, sal e similares". Essa atividade pode ser tipicamente rural, dependendo do local da prestação dos serviços (propriedade rural ou prédio rústico) e da atividade econômica da pessoa contratante (empregador rural). Nesse sentido, poder-se-ia entender falho o argumento da autora, já que estão previstas atividades possivelmente

\footnotetext{
${ }^{243}$ Art. $9^{\circ}$ : São segurados obrigatórios da previdência social as seguintes pessoas físicas:

(...)

VI - como trabalhador avulso - aquele que, sindicalizado ou não, presta serviço de natureza urbana ou rural, a diversas empresas, sem vínculo empregatício, com a intermediação obrigatória do órgão gestor de mãode-obra, nos termos da Lei no 8.630, de 25 de fevereiro de 1993, ou do sindicato da categoria, assim considerados:

a) o trabalhador que exerce atividade portuária de capatazia, estiva, conferência e conserto de carga, vigilância de embarcação e bloco;

b) o trabalhador de estiva de mercadorias de qualquer natureza, inclusive carvão e minério;

c) o trabalhador em alvarenga (embarcação para carga e descarga de navios);

d) o amarrador de embarcação;

e) o ensacador de café, cacau, sal e similares;

f) o trabalhador na indústria de extração de sal;

g) o carregador de bagagem em porto;

h) o prático de barra em porto;

i) o guindasteiro; e

j) o classificador, o movimentador e o empacotador de mercadorias em portos;

${ }^{244}$ PELEGRINI, Mari Ângela. op. cit., p. 48.
} 
rurais na enumeração do Regulamento. Entretanto, não obstante isso, permanece válido o entendimento de que o rol do artigo $9^{\circ}$, inciso VI, do Regulamento da Previdência Social é meramente exemplificativo, pois o serviço prestado não é o que caracteriza o avulso enquanto tal, não é sua marca peculiar. Ademais, historicamente o Regulamento da Lei n. ${ }^{\circ}$ 8.212/91 sempre previu a possibilidade de outras atividades também serem executadas por trabalhadores avulsos. A supressão da norma se deu não para restringir a ideia, mas para afastar a necessidade de classificação prévia do Ministério do Trabalho.

Nesse contexto, há que se concordar com a conclusão da autora de que o sistema de trabalho avulso é perfeitamente aplicável para o exercício de outros serviços, urbanos ou rurais $^{245}$. Considera-se também o princípio segundo o qual ninguém é obrigado a deixar de fazer algo senão em virtude de lei, e não há norma legal proibindo o trabalho avulso em atividades diversas da de movimentação de mercadorias.

Ou seja, o ordenamento jurídico, ao se referir ao modelo de relação laboral denominado trabalho avulso, mencionou apenas atividades e tarefas relacionadas à movimentação de mercadorias. Tal limitação está calcada em motivos históricos e sociais, pois como afirma Amauri Mascaro Nascimento ${ }^{246}$, foi a partir da necessidade de carregamento e descarregamento de mercadorias que o modelo de relação trabalhista se desenvolveu e se aperfeiçoou. Entretanto, não se trata de limitação absoluta, não há vedação legal para a utilização do trabalho avulso em outras atividades, sendo plenamente viável a extensão do modelo para outros serviços. Como visto acima, Ubiracy Torres $\mathrm{Cuóco}^{247}$ mencionou colheita de produtos rurais como exemplo de serviço a ser executado por trabalhador avulso. Amauri Mascaro Nascimento ${ }^{248}$ aponta a utilização do trabalho avulso com garçons:

"O avulso não portuário surgiu espontaneamente quando essa intermediação passou a ser feita em outras atividades e não apenas na portuária, como aconteceu, também, com a dos órgãos representativos dos garçons e outros que são contratados para prestar serviços eventuais em banquetes, festas, casamentos, etc.".

\footnotetext{
${ }^{245} \mathrm{~A}$ autora, após profunda análise sobre o trabalho dos eventuais, defende o sistema de trabalho avulso como a melhor solução para a inserção previdenciária e proteção jurídica dos trabalhadores eventuais rurais (volantes ou bóias frias), faxineiras, pedreiros e outros. PELEGRINI, Mari Ângela. op. cit., p. 227-237.

${ }^{246}$ NASCIMENTO, Amauri Mascaro. O avulso não-portuário e o trabalho rural, cit., p. 159.

${ }^{247}$ CUÓCO, Ubiracy Torres. op. cit.,p. 476.

${ }^{248}$ NASCIMENTO, Amauri Mascaro. O novo conceito de trabalhador avulso, cit., p. 5.
} 
Como pressuposto dessa extensão do modelo avulso para atividades não ligadas à movimentação de mercadorias, há que se respeitar, sempre, o princípio da primazia da realidade sobre a forma, prevalecendo a relação empregatícia nos casos em que a fraude for intentada. Além disso, há que se levar em conta as peculiaridades das atividades. Destarte, afastando-se as situações fraudulentas e promovendo as adaptações necessárias às características próprias de cada atividade, não se percebe qualquer impossibilidade, proibição ou inconveniência para a ampliação da utilização do trabalho avulso. Principalmente se for levado em conta que aos trabalhadores avulsos estão garantidos os mesmos direitos dos trabalhadores com vínculo empregatício, conforme artigo $7^{\circ}$, inciso XXXIV da Constituição da República. Ou seja, a utilização do trabalho avulso não significa, salvo fraudes, supressão de direitos trabalhistas.

Nesse ponto, há que se observar o artigo 14 do Regulamento das Relações Individuais e Coletivas de Trabalho Rural, aprovado pelo Decreto n. ${ }^{\circ}$ 73.626/74. Reza o artigo:

\footnotetext{
"As normas referentes à jornada de trabalho, trabalho noturno, trabalho do menor e outras compatíveis com a modalidade das respectivas atividades aplicam-se aos avulsos e outros trabalhadores rurais que, sem vínculo de emprego, prestam serviços a empregadores rurais."
}

Trata-se de expressa autorização normativa para utilização do modelo de trabalho avulso nas atividades rurais. A enumeração das normas aplicáveis ao trabalho avulso (jornada, trabalho noturno e do menor) é meramente exemplificativa, pois o artigo menciona expressamente a aplicação de “outras (normas) compatíveis". Trata-se da regulamentação do artigo 17 da Lei n. $^{\circ}$ 5.889/73, que estende aos trabalhadores não empregados, incluídos os avulsos, a aplicação das suas normas.

Os direitos do trabalhador avulso nas atividades rurais gozariam, portanto, de dupla equiparação com os direitos próprios dos empregados. Uma advinda do artigo $7^{\circ}$, inciso XXXIV da Constituição da República; outra advinda do artigo $17^{\circ}$ da Lei n. ${ }^{\circ}$ 5.990/73, regulamentado pelo artigo 14 do respectivo regulamento, estendendo aos avulsos a aplicação das normas próprias da relação empregatícia rural.

Neste contexto, entende-se viável a utilização do trabalho avulso no meio rural, para atividades não relacionadas à movimentação de mercadorias, mas próprias do meio, como tratos culturais e colheita de produtos rurais. Restaria a dúvida a respeito da 
possibilidade de intermediação pelo sindicato ou necessidade de criação de órgão semelhante ao órgão gestor de mão de obra, previsto na lei dos portuários.

Nelson Mannrich ${ }^{249}$ entende ser plenamente viável a utilização do trabalho avulso no meio rural, estando inclusive previsto em Parecer n. ${ }^{\circ} 76$, da Consultoria Jurídica do Ministério do Trabalho e Emprego. Apresentando-se como alternativa às cooperativas, os sindicatos teriam a função de cobrar dos tomadores pelo serviço prestado, levando em consideração todos os encargos e direitos trabalhistas, como FGTS, $13^{\circ}$ e afins, "sem prejuízo de uma taxa de administração, nova fonte de recursos para o sindicato" ${ }^{250}$.

O autor ${ }^{251}$ conclui defendendo a validade do trabalho rural avulso, cabendo aos sindicatos a coragem e o preparo para o enfrentamento das necessárias mudanças impostas pela evolução social e jurídica:

"A intermediação de mão de obra avulsa pelo sindicato não só é legal, como representa verdadeiro desafio em face das novas funções que lhe são atribuídas. $O$ trabalho avulso rural corresponde a uma solução racional para trabalhos de curta duração no campo (no meio artístico corresponde a 7 dias), não se admitindo sua utilização no lugar dos contratos de safra ou como expediente para burlar direitos trabalhistas."

Trata-se, sem dúvida, de desafio aos sindicatos profissionais rurais. É de amplo conhecimento a dificuldade que já enfrentam para o exercício da tarefa a eles atribuída constitucionalmente, de representação e defesa dos interesses da categoria. Aliar a essa tarefa a de figurar como intermediário na relação de trabalho avulso equivale, para muitos dos sindicatos de trabalhadores rurais, a vencer obstáculo quase intransponível.

Mari Ângela Pelegrini ${ }^{252}$ defende o trabalho avulso como a melhor saída para a informalidade dos eventuais rurais, mesmo com as dificuldades identificadas em sua pesquisa, como o despreparo e desinteresse dos sindicatos profissionais rurais para a assunção da tarefa de intermediador de mão de obra ${ }^{253}$. O caminho seria, segundo a autora, a criação do OGMO rural, com participação de servidores estatais, aprovados por concurso público, na gestão do órgão ${ }^{254}$, já que interesses públicos estariam também em jogo, como

\footnotetext{
${ }^{249}$ MANNRICH, Nelson. Alternativas para o trabalho rural, cit., p. 37 e ss.

${ }^{250}$ Id., Ibdi., p. 37.

${ }^{251}$ Id. Ibid., p. 38.

${ }^{252}$ Nas palavras da autora: "Segundo o ponto de vista que ora se defende, a migração dos chamados eventuais para a condição de avulso seria a melhor solução para a organização da categoria, sendo mais uma (senão a melhor) opção de sua inserção no mercado de trabalho.” PELEGRINI, Mari Ângela. op. cit., p. 218.

${ }^{253}$ Id. Ibid., p. 103.

${ }^{254}$ Id. Ibid., p. 229.
} 
arrecadação previdenciária e FGTS ${ }^{255}$. A criação de OGMO em zona não portuária não é ideia nova, citando a própria autora ${ }^{256}$ o projeto de lei de Irany Ferrari nesse sentido.

Como vantagem do trabalho avulso há que se ressaltar: o sistema possibilita a intermediação da mão de obra, é dizer, o tomador dos serviços contrata não os trabalhadores diretamente, mas uma terceira pessoa, responsável por fornecer a mão de obra e repassar aos trabalhadores o pagamento global feito por aquele. Assemelha-se à terceirização, no entanto, como importantes diferenças. A que primeiro salta aos olhos é a regulamentação minuciosa em lei das responsabilidades do tomador e do intermediador, garantindo-se aos trabalhadores, constitucionalmente, os mesmos direitos dos empregados, enquanto que, com relação à terceirização, ressente-se o Brasil da ausência de lei regulando a matéria, à exceção do trabalho temporário. Outra diferença de suma importância é a ausência de objetivos lucrativos do agente intermediador, no sistema de trabalho avulso. Mari Ângela Pelegrini ${ }^{257}$ é inequívoca:

"Interessante registrar a natureza jurídica do OGMO, como pessoa
jurídica de direito privado que se identifica como uma sociedade civil
sem fins lucrativos, atuando principalmente na administração dos avulsos
portuários, ao seu lado se coloca como um parceiro solidário, ao lado do
sindicato."

Sobre o tema, Gustavo Fillipe Barbosa Garcia ${ }^{258}$ afirma ser o OGMO “entidade civil de utilidade pública sem fins lucrativos.". O objetivo não lucrativo é o que legitima a atuação do intermediador no trabalho avulso, quer seja o OGMO, quer seja o sindicato. Sem buscar lucros, o agente intermediador não se submete à lógica de reduzir custos para aumentar ganhos, afastando-se da "tentação" de sonegar direitos trabalhistas. O intermediador, afastados os casos de fraude, tem maior margem para agir respeitando os

\footnotetext{
${ }^{255}$ Não se aprova, a princípio, tal participação. Recolhimentos previdenciários e de FGTS, como interesse público, não justifica a presença de agente estatal na gestão de qualquer entidade. Por uma questão de respeito ao princípio da isonomia, se é necessário estar presente um servidor público no OGMO, também o seria nas empresas de trabalho temporário, intermediadoras de mão de obra. Mais que isso, se o motivo são os recolhimentos previdenciários e fundiários, o agente precisaria estar também na administração de todo e qualquer empregador. Vislumbra-se, nessa situação hipotética, afronta ao princípio constitucional da livre iniciativa. Ao Estado cabe, na proteção do interesse público nos recolhimentos previdenciários e de FGTS, fiscalizar e punir de maneira exemplar os transgressores, mas preservando a presunção de inocência e a livre iniciativa.

${ }^{256}$ PELEGRINI, Mari Ângela. op. cit., p. 229.

${ }^{257}$ Id. Ibid., p. 52.

${ }^{258} \mathrm{O}$ autor ressalta o artigo 25 da Lei n. ${ }^{\circ}$ 8.630/93, que afirma ser o OGMO órgão de utilidade pública, sendo a ele vedados o fim lucrativo e o exercício de qualquer atividade a terceiros ou não vinculada à gestão de mão de obra. GARCIA, Gustavo Filipe Barbosa. op. cit., p. 276.
} 
direitos dos trabalhadores, inclusive os relativos à segurança e saúde no trabalho, e os encargos previdenciários e relativos ao FGTS.

Assim, o modelo de trabalho avulso consegue reduzir os custos para os tomadores, dispensados da burocracia e custos da contratação formal e direta de empregados, pelo curto tempo necessário. Ao mesmo tempo, não significa diminuição dos direitos trabalhistas, haja vista a garantia constitucional do art. $7^{\circ}$, inciso XXXIV.

\subsection{Trabalho avulso para serviços rurais não ligados à movimentação de mercadoria - (in)viabilidade prática}

Observa-se existir, no ambiente rural, pelo menos uma condição material idêntica à encontrada na região portuária, palco do desenvolvimento do trabalho avulso. Trata-se da necessidade, sentida por diversos empreendedores, de mão de obra por curtos espaços de tempo, sem se mostrar conveniente a burocracia e o custo do vínculo empregatício com cada um dos tomadores, diante da grande rotatividade dos trabalhadores e do curto período em que os serviços são necessários. Ainda que os períodos não sejam tão curtos como no meio portuário, em que se cogita a hipótese de período de seis horas ${ }^{259}$ por tomador, a necessidade do produtor rural, muitas vezes, não chega a durar uma semana (colheita de determinados produtos em pequenas áreas, pequenos tratos culturais). A presença dessas condições materiais é atestada pela experiência do consórcio de empregadores rurais, somente viável em função dela.

A viabilidade jurídica da transposição do sistema de trabalho avulso para o meio rural, voltado não para as atividades de movimentação de mercadoria, mas para as eminentemente agropastoris, é oportunidade de aumentar os índices de formalização da relação de trabalho dos rurícolas, sejam empregados sem registro contratados por curtos períodos, sejam os volantes de um único dia em cada propriedade. Entretanto, há que se atentar para uma questão de ordem prática: a diferença gritante entre o meio de trabalho portuário, origem do trabalho avulso, e o meio rural. Naquele há um único local, o porto,

\footnotetext{
${ }^{259}$ Segundo Roque Jurandy de Andrade Júnior: "A prestação de serviços de curta duração se explica pelo fato de o trabalhador avulso não se fixar a nenhuma fonte de trabalho (tomador de serviço), exercendo seu mister por um período determinado (em regra, por um turno de trabalho de seis horas) para várias empresas.”. ANDRADE JÚNIOR, Roque Jurandy. op. cit., p. 144.
} 
para onde convergem todos os elementos da relação. Como dito acima ${ }^{260}$, essa condição especialmente verificada no setor portuário certamente foi determinante para, inclusive, a forte capacidade de união, organização, e negociação dos trabalhadores portuários.

A centralização do local da prestação dos serviços permite aos trabalhadores o poder da união e articulação, alimentado pelo convívio diário e pela identificação dele decorrente. Possibilita, destarte, a diminuição da diferença de poder para com os tomadores dos serviços, dependentes daquele único local e dos trabalhadores que lá, e somente lá, se ativam. Os tomadores, por outro lado, apesar de conviverem também no mesmo local portuário, o fazem por curtos períodos, apenas no momento do embarque e desembarque da mercadoria. Há grandes distâncias entre os diversos tomadores, quer com relação aos locais das suas sedes, quer com relação ao setor econômico em que atuam. Ou seja, os tomadores não gozam de união ou identificação maior que a existente entre os trabalhadores.

Outra circunstância peculiar é a possibilidade de a organização de trabalhadores, OGMO, observar de perto todas as atividades laborais dos cadastrados, reprimindo aqueles que, buscando ganhos imediatos maiores, poderiam ser arregimentados por tomadores descontentes com a organização. É dizer, qualquer trabalho ligado à movimentação de mercadoria das embarcações é realizado no porto, sob o olhar atento da organização dos trabalhadores, que adquire, já por isso, maior poder na administração da mão de obra.

No meio rural isso não acontece, verificando-se, mesmo, situações opostas. O local da prestação dos serviços não é centralizado, ao contrário, é pulverizado pelas diversas propriedades rurais. Assim, o sindicato profissional intermediador, ou o OGMO rural a ser constituído, teria de exercer suas atribuições não em uma área restrita ao tamanho de um porto, mas grande o suficiente para abarcar os diversos tomadores de serviços, que precisam ser vários, para garantir a manutenção da demanda constante pela mão de obra. Em se tratando de sindicato intermediador, a área mínima seria a de um município, por força do inciso II do art. $8^{\circ}$ da Constituição da República.

Há sempre a possibilidade de um tomador de serviço, insatisfeito com a organização dos trabalhadores, ou com os custos da contratação formal, atrair mão de obra irregular com remuneração imediata maior, porém sem as mínimas garantias de segurança e saúde, e sem inserção alguma no sistema previdenciário e do FGTS. Trata-se de prática

\footnotetext{
${ }^{260}$ Ver supra fls. 76 e ss.
} 
não rara no meio rural, a chamada "bocada", ou "contrato de bocada", descrita por Marilda Izique Chebabi ${ }^{261}$ como o contrato para a colheita de pequena quantidade de laranja, demandando dois ou três dias de serviço. Geralmente a turma é contratada por quem precisa colher poucos frutos, ou dono de mercado ou pequeno produtor, sendo incomum a contratação nesses moldes pela grande indústria. A turma contratada recebe valor previamente combinado e fixo por caixa de laranja colhida, geralmente em nível acima do normal, sem qualquer formalização do vínculo trabalhista. Por vezes, os trabalhadores da "bocada" estão registrados por outros empregadores e faltam ao serviço por um ou dois dias, em busca da remuneração imediata maior. Trata-se de situação que dificilmente aconteceria no porto, sob a vigilância atenta do OGMO. Já no meio rural com propriedades dispersas por longas distâncias, seria difícil ao intermediador se garantir contra tais artimanhas, fiscalizar todas as propriedades rurais, ou pelo menos, todos os pontos de transporte rural da sua região.

Outra diferença: os produtores rurais, todos de um determinado município, ou determinada região, estão mais próximos entre si e todos praticam atividade econômica similar, a produção agropecuária. Estão, outrossim, geralmente articulados e agrupados em sindicatos ou cooperativas de produtores. Gozam de estrutura associativa mais significativa que os trabalhadores. Estes, por sua vez, sofrem com as grandes distâncias, próprias do meio rural. $\mathrm{O}$ grande número de trabalhadores migrantes também dificulta a associação e união dos trabalhadores, desvinculados do local da prestação dos serviços e do sindicato local. Ou seja, se no setor portuário pode-se identificar um grau associativo dos trabalhadores maior que dos tomadores ou beneficiários da força de trabalho, no setor rural a lógica se inverte, dificultando e praticamente anulando o poder de organização e de autogestão dos trabalhadores.

Os mesmos motivos apontados por Mari Ângela Pelegrini ${ }^{262}$ para a inaplicabilidade do cooperativismo no meio rural, como baixo nível cultural e de escolaridade dos rurícolas, debilitados na capacidade de autogestão, ajudam a explicar a dificuldade de se implantar o trabalho avulso para atividades rurais de curta duração.

A intensa migração sentida no meio rural significa, além disso, obstáculo significativo para o cadastro e administração da mão de obra a ser intermediada. A constante migração, e consequente grande variação no número de trabalhadores em uma

\footnotetext{
${ }^{261}$ CHEBABI, Marilda Izique. op. cit., p. 202.

${ }^{262}$ PELEGRINI, Mari Ângela. op. cit., p. 191-193. Trecho transcrito às fls. xx.
} 
determinada região, dificultam sobremaneira a elaboração de escalas de revezamento. A acentuada dispersão dos locais de trabalho, de alojamento e moradia dos trabalhadores rurais, aliada aos infelizmente tradicionais baixos índices de escolaridade e alfabetização dessa população, dificultam a auto-organização. Também a diversidade dos locais de origem dos trabalhadores migrantes e a diversidade de culturas agrícolas para as quais se dedicam dificultam a identificação entre os próprios obreiros, já fragilizada pelo convívio em menor proporção que o percebido no meio portuário.

Como se nota, muitas são as diferenças entre as atividades de movimentação de mercadorias, especialmente portuárias, e as específicas da agropecuária, ou até mesmo da indústria rural. Tais diferenças justificam, certamente, a enorme diferença entre a situação dos trabalhadores portuários e dos trabalhadores rurais, principalmente os volantes ou eventuais, com relação à conquista e efetividade dos seus direitos trabalhistas. Revelam, também, a grande dificuldade prática de se implantar o sistema de trabalho avulso no ambiente rural, para atividades diversas da movimentação de mercadorias. Certamente tais circunstâncias contribuem para explicar o motivo pelo qual as experiências tentadas foram “frustradas", nas palavras de Mari Ângela Pelegrini ${ }^{263}$. Segundo a autora ${ }^{264}$, circunstâncias como "fraudes", "má-fé" e "preconceito", minaram as possibilidades de sucesso do desenvolvimento do trabalho avulso no meio rural, com intermediação do sindicato.

A autora ${ }^{265}$ defende a instituição do OGMO rural com forte interferência estatal, capaz de organizar os trabalhadores de forma mais imparcial. Entretanto, a intervenção estatal no papel de agente intermediador de mão de obra não supera as dificuldades elencadas acima, além de ir pela contramão da valorização da iniciativa privada coletiva, constituindo-se mais um obstáculo para a possibilidade de autogestão dos trabalhadores, lembrando momentos "Getulistas" em que se imiscuíam e misturavam entidades governamentais e representativas dos trabalhadores.

Em resumo, conclui-se que, embora haja possibilidade normativa da utilização do trabalho avulso para os serviços rurais, não havendo proibição legal para tanto, a realidade muito diferente da atividade rural, discrepante e muitas vezes oposta da realidade portuária,

\footnotetext{
${ }^{263}$ PELEGRINI, Mari Ângela. op. cit., p. 231.

264 "É que, para a condição de avulso rural, via intermediação sindical, não há, atualmente, nenhum impedimento legal. Tanto é verdade que nenhum sindicato interessado em fazer essa intermediação hesitou em levar a cabo seu intento. Infelizmente, ao que tudo indica, houve fraudes, a exemplo das cooperativas, naufragando, antes mesmo de velejar, essa importante e inquestionável alternativa de contratação. Mais uma vez, a má-fé de uns e o preconceito de muitos impediu que a legislação já existente servisse de suporte para uma forma inegavelmente benéfica de contratação dos volantes no meio rural.” Id. Ibid., p. 218.

${ }^{265}$ Id. Ibid., p. 227 e ss.
} 
revela-se significativo obstáculo para a transposição do sistema dos portos para os campos. Muitas adaptações seriam necessárias, envolvendo diversos elementos, como a conscientização e mobilização do movimento sindical e passando, necessariamente, pelo fortalecimento da capacidade de organização e mobilização dessa classe trabalhadora, o que requer, de início, aumento do seu nível cultural e educacional. Para isso, demandam-se tempo, iniciativas públicas e vontade política, fatores que, infelizmente, ainda não se fizeram presentes com força suficiente para garantir sequer escolas públicas de qualidade na a zona rural brasileira, desde os tempos de Império. 


\section{CONSÓRCIO DE EMPREGADORES RURAIS}

\subsection{Antecedentes}

A figura do consórcio de empregadores rurais nasceu a partir da iniciativa dos próprios atores sociais envolvidos, no início da década de 1990, como alternativa à utilização das cooperativas fraudulentas ${ }^{266}$.

Segundo Nelson Mannrich ${ }^{267}$, a figura foi inicialmente idealizada em São Paulo pela FAESP (Federação da Agricultura do Estado de São Paulo), em 1996. Em monografia sobre o tema, Viviane Aparecida Lemes ${ }^{268}$ com base em Dirceu Galdino ${ }^{269}$, indica que no estado do Paraná o modelo se originou a partir da busca dos produtores rurais por alternativas às cooperativas, em 1994, sendo implementado no ano de 1995, após debates com a Procuradoria do INSS e apoio da então denominada Delegacia Regional do Trabalho do Paraná (atualmente Superintendência Regional do Trabalho do Paraná). É necessário esclarecer, entretanto, que é impossível afirmar a implementação, em 1995, do Consórcio nos moldes hodiernos, pois a legislação que lhe dá os atuais contornos, possibilitando inclusive o tratamento previdenciário de pessoa física, ainda não existia. Somente em 1999 foram elaboradas a Circular n. ${ }^{\circ}$ 56, do INSS e a Portaria 1964/99 do Ministério do Trabalho e Emprego, e somente em 2001 a Lei n. ${ }^{\circ}$ 8.212/91 foi alterada, equiparando a empregador pessoa física o consórcio simplificado de produtores rurais. Sérgio Pinto Martins ${ }^{270}$ cita a busca pela regularização de uma cooperativa de produtores rurais, na cidade de Rolândia, no Paraná, em 1997, com a participação do Ministério Público do Trabalho, como embrião da formação do consórcio.

\footnotetext{
${ }^{266}$ Nesse sentido, entre outros, DAMIANO, Henrique. op. cit., p. 192; ANDRADE, Dárcio Guimarães de. I A ação civil pública e o FGTS II - Condomínio de empregadores. LTr: suplemento trabalhista, São Paulo, v. 37, n. 58, p. 285, 2001.

${ }^{267}$ MANNRICH, Nelson. Consórcio de empregadores rurais. IOB: repertório de jurisprudência: trabalhista e previdenciário, São Paulo, n. 20, p. 396-394, out. 2000.

${ }^{268}$ LEMES, Viviane Aparecida. A figura jurídica do consórcio de empregadores rurais: reflexões teóricas a partir de exemplos práticos. São Paulo: LTr, 2004. p. 54. Trabalho originalmente apresentado como dissertação de mestrado pela Unimep - Universidade Metodista de Piracicaba. Neste trabalho, mais adiante, a autora registra também que a "Faesp realizou estudos no sentido de viabilizar a contratação de trabalhadores rurais para prestarem serviços a vários agricultores, o que permitiu o alongamento do período de contratação e o cumprimento de todos os requisitos legais para a formalização da relação de trabalho, culminando na criação dos consórcios de empregadores no estado de São Paulo.” p. 65.

${ }^{269}$ GALDINO, Dirceu. Uma forma vantajosa de registrar empregados sem intermediação. Revista LTr, São Paulo, ano 62, n. 2, p. 184-190, fev. 1998.

${ }^{270}$ MARTINS, Sergio Pinto. Consórcio de empregadores rurais. Orientador Trabalhista: suplemento de legislação, jurisprudência e doutrina, São Paulo, v. 19, n. 4, p. 5, abr. 2000.
} 
Embora a criação do consórcio de empregadores rurais tivesse a participação dos atores sociais envolvidos, sua implantação não foi tranquila. O INSS, inicialmente, enquadrou a figura como empresa urbana, equiparando-a a empresa prestadora de serviço $^{271}$. Observa-se a impropriedade de tal enquadramento, pois o consórcio de empregadores tem por objetivo permitir justamente a contratação direta, sem intermediação de empresas prestadoras de serviço. Ademais, não se constitui uma empresa, pois não há a conjugação de esforços para a consecução de um objeto social, não há uma organização produtiva única. A reunião é meramente para a contratação e gerenciamento da mão de obra, preservando cada produtor rural sua unidade econômica e produtiva, podendo inclusive concorrer com os demais consorciados no mercado.

Foram necessárias medidas judiciais para garantir que a nova figura pudesse ser viabilizada. Segundo Viviane Aparecida Lemes $^{272}$, a Divisão de Arrecadação e Fiscalização do INSS do Paraná, de início, deferiu ao consórcio a matrícula previdenciária própria de pessoa física, mas depois alterou para matrícula previdenciária de associação de empregadores, com tratamento próprio de empresa, aumentando os encargos previdenciários. Somente após provocação do Poder Judiciário se reconheceu o direito dos produtores rurais de se reunirem com o fim exclusivo de contratação de mão de obra, sem a união empresária, sem a conjugação de suas atividades econômicas. Após a chancela do Poder Judiciário é que foi elaborada a Circular do INSS n. ${ }^{\circ 56 / 99}$ e a Portaria do MTE n. ${ }^{\circ}$ 1.964/99. Essas foram, então, as bases normativas para a reforma introduzida pela Lei n. ${ }^{\circ}$ 10.256/01, reconhecendo o novo modelo de contratação como empregador equiparado.

\subsection{Identificação da figura contratual}

Como visto, o consórcio de empregadores rurais foi inicialmente cogitado pela Circular INSS n. ${ }^{\circ}$ 56, de 25 de outubro de 1999 e pela Portaria do Ministério do Trabalho e Emprego n. ${ }^{\circ} 1.964$, de $1^{\text {o }}$ de dezembro de 1999. Em 2001, a Lei n. ${ }^{\circ} 10.256 / 01$ alterou a Lei n. ${ }^{\circ}$ 8.212/91, sendo a figura, a partir de então, reconhecida legalmente como empregador equiparado. Essa lei deu solução a uma importante crítica levantada por Sérgio Pinto Martins $^{273}$. O autor, atento ao princípio da legalidade (art. $5^{\circ}$, II da Constituição da

\footnotetext{
${ }^{271}$ MANNRICH, Nelson. Consórcio de empregadores rurais, cit., p. 396.

${ }^{272}$ LEMES, Viviane Aparecida. op. cit., p. 55.

${ }^{273}$ MARTINS, Sergio Pinto. Consórcio de empregadores rurais, cit., p. 5-8.
} 
República), segundo o qual ninguém é obrigado a fazer ou deixar de fazer algo a não ser em virtude de lei, afirmara, em 2000, que uma simples Portaria não poderia criar a nova figura jurídica. Nas suas palavras: "Para que o consórcio fosse reconhecido como empregador deveria haver lei regulando o tema." 274

Após a previsão legal, o consórcio pode ser entendido como a união de produtores rurais, pessoas físicas, com a finalidade exclusiva de criar um ente coletivo único, que será empregador por equiparação de trabalhadores rurais. Estes se obrigam a prestar serviço a quaisquer produtores consorciados, que por sua vez, respondem solidariamente pelas obrigações trabalhistas e previdenciárias. Diversas são as definições encontradas na doutrina. Marco Antonio Cesar Villatore ${ }^{275}$ define a figura da seguinte maneira:

“A união de produtores rurais, pessoas físicas, com a intenção de registro em comum de empregados rurais e para diluir os custos dessas novas contratações especiais, manutenções e rescisões contratuais, mediante documento devidamente firmado por todos e registrado em cartório de títulos e documentos, caracterizando a solidariedade entre os mesmos".

Aurélio Pires ${ }^{276}$ afirma ser o consórcio de empregadores rurais uma forma atípica de contratação, contrapondo-o a outras formas também atípicas que, "em grande parte, têm seu desfecho nos Pretórios Trabalhistas", como intermediação de mão de obra e cooperativa, entre outros. Em termos que serão posteriormente mencionados por Henrique Damiano $^{277}$, confere a seguinte definição ao instituto:

"A possibilidade de um grupo de empregadores rurais - excluída, pois, expressamente a pessoa jurídica empregador rural - poderem contratar assalariados rurais, tendo estes a obrigação de prestar serviços a todos os integrantes do Consórcio, que passa a ser, efetivamente, o empregador desses trabalhadores".

Ricardo Tadeu Marques da Fonseca ${ }^{278}$, em breve artigo que aborda os diversos tipos de contratação no meio rural, é mais sucinto ao afirmar que o Consórcio de Empregadores Rurais pode ser entendido como uma alternativa às falsas cooperativas, que

${ }^{274}$ MARTINS, Sergio Pinto. Consórcio de empregadores rurais, cit., p. 6.

${ }^{275}$ VILLATORE, Marco Antonio César. Consórcio simplificado de empregadores rurais. In: GIORDANI, Francisco Alberto da Motta Peixoto; MARTINS, Melchíades Rodrigues; VIDOTTI, Tarcio José (Coords.). Direito do trabalho rural: homenagem a Irany Ferrari, cit., p. 430-454.

${ }^{276}$ PIRES, Aurélio. Consórcio de empregadores rurais. Revista LTr, São Paulo, ano, 65, n. 10, p. 1209-1211, out. 2001.

${ }^{277}$ DAMIANO, Henrique. op. cit., p. 193.

${ }^{278}$ FONSECA, Ricardo Tadeu Marques da. Modalidades de contratação no meio rural e o consórcio de empregadores. LTr: suplemento trabalhista. São Paulo, v. 37, n. 17, p. 99, 2001. 
aumentaram os custos dos empregadores rurais. Estes então "propuseram o consórcio de empregadores, que consiste numa sociedade de produtores rurais para gestão coletiva de mão de obra". O termo "sociedade" não deve, aqui, ser entendido nos moldes técnicojurídicos, pois o consórcio de empregadores rurais não possui as mesmas características que a legislação atribui às sociedades ${ }^{279}$.

Boa parte dos doutrinadores, ao definir o instituto, parte do conceito constante da Portaria n. ${ }^{\circ} 1.964$, de $1^{\circ}$ de dezembro de 1999, do Ministério do Trabalho e Emprego. O artigo $1^{\circ}$ desta portaria assim dispõe:

Art. 1o As Delegacias Regionais do Trabalho deverão dar ampla
divulgação ao modelo de contratação rural denominado "Consórcio de
Empregadores Rurais", estimulando, para tanto, o debate entre produtores
e trabalhadores rurais, por meio de suas entidades associativas ou
sindicais.
Parágrafo único. Para os fins do disposto nesta Portaria, considera-se
"Consórcio de Empregadores Rurais" a união de produtores rurais,
pessoas físicas, com a finalidade única de contratar empregados rurais.
(grifou-se).

A Portaria estabelece, além de um conceito, uma denominação ao modelo de contratação rural. A opção da norma - Consórcio de Empregadores Rurais - não é isenta de críticas. Para que sejam analisadas tais críticas de maneira mais producente, entretanto, é interessante compreender anteriormente as principais características do instituto, merecendo olhar mais aprofundado as suas bases normativas.

\subsection{Bases normativas e principais características}

Levando-se em consideração a cronologia em que as normas foram inseridas no ordenamento jurídico, a circular n. ${ }^{\circ} 56$ do $\operatorname{INSS}^{280}$ aponta como fatores a serem levados em

\footnotetext{
${ }^{279}$ A distinção entre sociedade e o consórcio será analisada adiante.

280، CIRCULAR INSS No 56, DE 25 DE OUTUBRO DE 1999:

Retifica a Circular INSS no 53, de 29 de setembro de 1999.

Considerando a sazonalidade e a eventualidade das tarefas laborais na atividade rural;

Considerando que as dificuldades operacionais das constantes contratações e dispensas dos empregados rurais induzem à informalidade;

Considerando que muitas propriedades rurais fazem parte do território de mais de um município, sendo impossível, nestes casos, a expedição de matrícula CEI/8 (barra oito) restrita a um único município:

Autorizo a expedição de matrícula CEI/8 (barra oito) para dois ou mais empregadores rurais pessoas físicas vinculados ao contrato de trabalho (art.12, V, alínea “a”, da Lei no 8.212/91), nas seguintes condições:

a) os empregados ficarão à disposição dos contratantes exclusivamente, em suas propriedades rurais, vedada a cessão a terceiros;
} 
consideração as peculiaridades do trabalho no campo e a dificuldade do produtor rural em manter a formalidade e legalidade dos contratos de trabalho. O consórcio surge, dessa maneira, com o reconhecimento pelo Estado das dificuldades dos produtores rurais, e viabilizado legalmente como alternativa aos empregadores, para lhes facilitar a legalidade na contratação e manutenção da mão de obra ${ }^{281}$.

A Circular autoriza a expedição de matrícula CEI própria de pessoa física para dois ou mais empregadores rurais pessoas físicas, desde que atendidas determinadas condições, passíveis de divisão em dois tipos: materiais e formais. As condições materiais são: 1) serem os empregadores pessoas físicas, conforme artigo 12, V, alínea "a" da Lei 8.212/91 (contribuinte individual), 2) a exclusividade da prestação dos serviços dos trabalhadores aos contratantes e nas suas propriedades e, por fim, 3) a localização em um mesmo município, ou em municípios limítrofes, das propriedades. As demais condições são de caráter formal ou instrumental, com importante finalidade prática: 1) a assinatura do pedido de matrícula por todos os contratantes, 2) a identificação de cada produtor rural, com seu respectivo CEI para efeito de contribuição sobre a comercialização de seus produtos, 3) o cadastro de todos os empregadores no sistema, 4) o registro do endereço onde a documentação ficará disponível à fiscalização e 5) a indicação do nome de um dos contratantes, seguido da expressão "e outros", no cadastro de matrícula. A Circular deixa claro que a matrícula a ser concedida será exclusivamente para fins de recolhimento das contribuições previdenciárias sobre remuneração do empregado.

Permanecendo cada produtor rural com o CEI próprio para o recolhimento da contribuição sobre a comercialização de sua produção, fica claro que cada um manterá sua

\footnotetext{
b) o pedido de matrícula será assinado por todos os empregadores;

c) as propriedades rurais vinculadas ao contrato de trabalho deverão se situar em um mesmo município ou em municípios limítrofes;

d) identificação de cada empregador e da propriedade rural, bem como a respectiva matrícula CEI para recolhimento das contribuições sobre a comercialização da produção prevista no art. 25, I, II e $\S 2 o$, da Lei no 8.212/91;

e) a matrícula é exclusiva para recolhimento das contribuições previdenciárias sobre remuneração previstas no art. 20 (empregado) da Lei no 8.212/91;

f) deverão ser cadastrados no sistema todos os empregadores rurais pessoas físicas vinculados ao contrato de trabalho;

g) registrar o endereço onde toda a documentação estará disponível à fiscalização;

h) consignar no Campo "NOME" do Cadastro de Matrícula o primeiro empregador relacionado, seguido da expressão "E OUTROS”.

${ }^{281} \mathrm{O}$ viés alternativo do novo modelo de contratação, em resposta à intensa informalidade no campo, é observado também por grande parte de doutrina. Citamos, por exemplo, Sérgio Pinto Martins: "No âmbito rural têm sido utilizadas muitas cooperativas fraudulentas, como intermediadoras de mão-de-obra, em que o trabalhador não tem qualquer garantia, sendo ignorados seus direitos trabalhistas. Daí houve a ideia de se formar o consórcio de empregadores rurais, visando regularizar o trabalho no campo". MARTINS, Sergio Pinto. Consórcio de empregadores rurais, cit., p. 5.
} 
individualidade produtiva e econômica, não se tratando de uma associação empresarial ou de uma união de esforços econômicos. A reunião de esforços é somente para fins de contratação de mão de obra, não se confundindo com a figura do grupo econômico mencionado no $\S 2^{\circ}$ do artigo $3^{\circ}$ da Lei n. $^{\circ} 5889 / 73^{282}$, pois não há empresas, não há direção, controle ou administração de um contratante em relação aos demais, não se podendo falar também em constituição de grupo econômico ou financeiro rural, já que cada produtor mantém a individualidade de sua economia, inclusive para fins de recolhimento de contribuição previdenciária sobre a comercialização de sua produção, como visto acima.

Segundo a Circular, os empregados somente poderão trabalhar para os consorciados, nas propriedades indicadas na matrícula, localizadas em um único município, ou municípios limítrofes. Trata-se de importante restrição, pois caso os trabalhadores pudessem prestar serviço em propriedades alheias ao consórcio, este se tornaria um intermediário de mão de obra, sujeito interposto, agindo como verdadeira empresa prestadora de serviço. Tal situação seria totalmente contrária aos objetivos do instituto, que se apresenta, conforme a própria Circular menciona, como alternativa de custo reduzido para que os produtores rurais possam manter a legalidade na contratação de trabalhadores, e não uma alternativa de baixo custo para a terceirização, ou intermediação da mão de obra. Não é por outra razão que o tratamento previdenciário é de pessoa física, não de empresa prestadora de serviço.

Logo após a Circular n. ${ }^{\circ} 56$ do INSS, o Ministério do Trabalho e Emprego editou a Portaria n. ${ }^{\circ}$ 1.964/99, determinando às Delegacias Regionais do Trabalho ampla divulgação do novo tipo contratual e estímulo ao debate entre produtores e trabalhadores rurais, ainda que por meio de seus representantes. Após definir o Consórcio de Empregadores Rurais, a Portaria disciplina como deve proceder a Inspeção do Trabalho ao fiscalizar esse tipo de empregador, apontando inclusive quais documentos deverão ser solicitados do consórcio, além dos necessários e comuns à atuação físcal, como registro dos empregados, por exemplo. Ao orientar a Inspeção do Trabalho, a Portaria estabeleceu,

\footnotetext{
${ }^{282}$ Nelson Mannrich diferencia de maneira clara os dois institutos: “essa nova modalidade não se confunde com o grupo econômico rural a que se refere o $\$ 2^{\circ}$ do art. $3^{\circ}$ da Lei do rural, pois, ao conceituar a figura do empregador, o legislador alude tanto a pessoa física, quanto a pessoa jurídica. Ora, o grupo econômico rural é constituído por duas ou mais empresas, nos termos da lei, enquanto que o consórcio e constituído por um grupo de pessoas físicas, que se associam com o exclusivo propósito de exploração conjunta da atividade rural mediante a utilização de empregados comuns”. MANNRICH, Nelson. Consórcio de empregadores rurais, cit., p. 395.
} 
ainda que de maneira indireta, as providências a serem tomadas pelos produtores rurais a fim de garantir a validade do consórcio.

Deve então o consórcio providenciar a matrícula coletiva CEI do INSS, nos termos da Circular INSS no 56 . A determinação desta Circular a respeito da indicação do nome de um dos produtores, seguido da expressão "e outros", na matrícula, ganha importância com a Portaria do MTE, pois é este nome que deverá constar como empregador nos diversos documentos relativos à relação laboral, como Carteira de Trabalho e Previdência Social (CTPS), registro de empregados, folhas de pagamentos e todos os demais.

Além dessa matrícula, o consórcio deverá manter um pacto de solidariedade, conforme artigo 896 do Código Civil de 1916, correspondente aos artigos 264 e 265 do Código Civil atual. Este pacto, que só valerá se registrado em cartório de títulos e documentos, deve conter a assunção da responsabilidade solidária dos pactuantes sobre as obrigações trabalhistas e previdenciárias decorrentes da contratação comum de trabalhadores, a identificação de cada consorciado, devidamente qualificado, bem como a indicação, com endereço, das propriedades onde os trabalhadores do consórcio poderão prestar serviço.

O consórcio deve manter também a documentação referente à outorga de poderes a um dos consorciados, ou a um gerente ou administrador, escolhido para gerir a contratação e utilização da mão de obra nas propriedades integrantes do grupo.

A relação de documentos indica as providências que os empregadores deverão tomar para que o consórcio seja considerado válido enquanto tal. Uma das questões que se coloca, então, é o aparente choque entre o princípio da legalidade e a determinação de tantas obrigações em uma simples Portaria. Poderia o empregador rural ser obrigado a, além de atender a todos os requisitos de uma simples Portaria, ainda responder solidariamente em função da norma infralegal? Tal situação não afrontaria o comando do artigo 256 do Código Civil, segundo o qual a solidariedade resulta somente de lei ou da vontade das partes? Observa-se que a Lei n. ${ }^{\circ}$ 10.256/01, alteradora da Lei n. ${ }^{\circ}$ 8.212/91, ao equiparar o consórcio simplificado de empregadores rurais a empregador pessoa física, mencionou a responsabilidade solidária somente em relação às obrigações previdenciárias, deixando passar a oportunidade de inserir expressamente, e pela via própria (lei em sentido estrito), a solidariedade para fins trabalhistas. 
A questão da responsabilidade solidária trabalhista e a série de requisitos estabelecidos em norma infralegal não se coloca como uma verdadeira afronta aos princípios do ordenamento jurídico. Uma reunião ou associação de produtores rurais que não atenda aos requisitos da Portaria e da Circular pode existir e ser válida, apenas não será considerada como um Consórcio de Empregadores Rurais. Não estará enquadrada no modelo que recebeu do ordenamento jurídico a autorização para contratar empregados rurais na condição de empregador único, recebendo tratamento previdenciário de pessoa física. Ainda que vários produtores rurais se reúnam em uma associação para gerir a contratação e utilização de mão de obra, se não forem atendidos os requisitos da Portaria, não haverá Consórcio de Empregadores Rurais, já que ausentes os pressupostos da Portaria. Cada produtor rural deverá, então, contratar individualmente os empregados (e providenciar, também individualmente, o registro dos trabalhadores), deixando de gozar do benefício proporcionado pelo consórcio, que é justamente a contratação e o registro único e coletivo. Toda a redução de custos permitida pelo modelo será perdida. Observa-se também que a solidariedade entre os produtores não é determinada pela Portaria, mas pelo pacto celebrado entre os produtores, ou seja, pela manifestação da vontade.

Em outras palavras, se os produtores rurais quiserem gozar dos benefícios que o consórcio de empregadores rurais proporciona, aproveitando a figura do empregador por equiparação como real alternativa para evitar os altos custos do contrato tradicional de emprego, deverão, por vontade própria, seguir o que determina a Portaria e a Circular. Deverão, voluntariamente, portanto, contratar e assumir a responsabilidade trabalhista solidária, afirmando-a no documento denominado pacto de solidariedade, a ser registrado em cartório. Percebe-se, portanto, que a responsabilidade solidária dos consorciados resulta da vontade das partes, que voluntariamente a assumem para poderem gozar dos benefícios que a figura proporciona. A solidariedade por obrigações previdenciárias, além de constar do acordo de vontades, está respaldada também pela lei, como visto acima.

Caso não sejam cumpridos os requisitos da Portaria, permanece válida a regra geral, o contrato de emprego com cada produtor, de maneira individualizada. Não há que se falar, portanto, em norma infralegal criando obrigações ao arrepio do princípio da legalidade. $\mathrm{O}$ que existe é uma exceção à regra geral, um subsistema permitido dentro do sistema maior, autorizando a contratação de empregados por um único empregador coletivo, desde que atendidos determinados requisitos. Os requisitos da Circular e da Portaria não são obrigatórios a todos os produtores rurais, somente aos que se dispuserem a constituir um 
consórcio. Tais requisitos fazem parte de um subsistema em que é permitido aos produtores rurais contratar empregados de uma maneira diversa (e menos custosa) da tradicional. Dentro desse subsistema, são estabelecidas as condições para que o produtor possa gozar dessa permissão. Não se trata, portanto, de uma norma que obriga, mas de uma norma que permite a utilização de um subsistema. Não é obrigação criada por norma infralegal, é permissão para o produtor rural se enquadrar em uma exceção à obrigação legal, que se apresenta muito custosa. Não se cumprindo os requisitos da Portaria e da Circular, cada produtor rural terá um contrato individual de trabalho com os empregados que se ativarem na sua propriedade, pois não se pode falar em Consórcio de Empregadores Rurais. Essa é a solução apontada pela doutrina ${ }^{283}$, destacando-se a afirmação de Nelson Mannrich, ${ }^{284}$ cristalina neste sentido:

\begin{abstract}
"Aliás, um dos documentos exigidos pela fiscalização do trabalho, para comprovar a existência do consórcio, refere-se ao pacto de solidariedade. Como não há lei obrigando a exibição do referido documento, e não sendo exibido, cabe ao agente da inspeção concluir que se trata de empregado comum sem registro, sujeitos às sanções previstas na CLT, descaracterizando, assim, o sistema do consórcio".
\end{abstract}

Entre os documentos necessários para a validade do consórcio está, como visto, o pacto de solidariedade. Trata-se de uma garantia aos trabalhadores, que poderão exigir seus créditos de qualquer um dos produtores que constem no pacto. Trata-se também de uma garantia ao INSS, já que a responsabilidade solidária refere-se também às obrigações previdenciárias. Tal solidariedade se estende, outrossim, para o campo das obrigações decorrentes das multas trabalhistas, aplicadas pela Inspeção do Trabalho, pois eventual autuação será lavrada no nome do consórcio, e não no nome daquele produtor em cuja propriedade foi flagrada a irregularidade, conforme artigo $4^{\circ}$ da Portaria 1.964/99 285 .

\footnotetext{
${ }^{283}$ Pode-se citar Threreza Cristina Nahas: “a questão que poderia se colocar é o fato de, por exemplo, não se constituir o consórcio da forma determinada, o que não nos parece resultar qualquer dificuldade, pois, se assim for, é certo que o contrato será nulo (art. $9^{\circ}$ da Consolidação das Leis do Trabalho) e cada um dos tomadores de serviço, certamente, terá com aquele empregado, um contrato de trabalho, podendo este reclamar tantos contratos quantos forem seus empregadores, estando, ainda, estes sujeitos às penalidades respectivas e, até mesmo, encerramento de suas atividades, dependendo da gravidade da falta cometida." NAHAS, Thereza Cristina. Inovações na lei do trabalho rural. LTr: suplemento trabalhista, São Paulo, v. 37, n. 7, p. 35-38, 2001.

${ }^{284}$ MANNRICH, Nelson. Consórcio de empregadores rurais, cit., p. 394.

${ }^{285}$ Art. $4^{\text {o. }}$ "Constatada a violação de preceito legal pelo "Consórcio de Empregadores Rurais", deverá o Auditor-Fiscal do Trabalho lavrar o competente Auto de Infração em nome contido na CEI (coletiva), citando, ainda, o CPF do produtor que encabeça a matrícula e fazendo constar no corpo desta peça as informações necessárias à caracterização da prestação de trabalho a produtores consorciados.

$\S 1$ o O Auditor-Fiscal do Trabalho deverá, sempre que possível, juntar ao Auto de Infração a cópia da CEI (coletiva) e do "Pacto de Solidariedade", a fim de garantir a perfeita identificação de todos os produtores rurais."
} 
Excetua-se o caso de afronta ao artigo 41 da CLT, cuja autuação deverá recair sobre o produtor rural individualmente, conforme $\S 2^{\circ}$ do art. $4^{\circ}$ da referida Portaria. Ou seja, se a fiscalização identificar irregularidades trabalhistas em quaisquer das propriedades constantes do consórcio, deverá lavrar o auto de infração contra o consórcio de empregadores, ou seja, em face do produtor que dá nome ao consórcio, seguido da expressão "e outros", fazendo constar do auto de infração a relação de todos os consorciados.

No entanto, se a inspeção do trabalho identificar empregados sem registro trabalhando para um produtor consorciado, o auto de infração por falta de registro não deverá ser lavrado em face do condomínio, mas daquele produtor específico. Há que se ressalvar, entretanto, importante corrente doutrinária que entende não ter o Auditor-Fiscal competência para reconhecer a existência do vínculo de emprego, matéria que seria reservada à Justiça do Trabalho, conforme artigo 114 da Constituição da República. Citase, nesse sentido, Sérgio Pinto Martins ${ }^{286}$ : "Não tem, contudo, competência o fiscal do trabalho para dizer se existe ou não o vínculo de emprego. A matéria só pode ser dirimida pela Justiça do Trabalho, conforme a previsão do artigo 114 da Constituição.”.

A solidariedade, entretanto, pode se tornar um entrave para a própria constituição do consórcio, observa Viviane Aparecida Lemes ${ }^{287}$, pois gera a necessidade de um alto grau de confiança entre os produtores. Tal grau de confiança poderá ser difícil de ser construído, considerando que em diversas situações os futuros associados concorrem no mercado pela venda de seus produtos ${ }^{288}$. A formação do consórcio poderá depender, então, de reuniões e debates em que se esclareçam as reais finalidades, vantagens e ônus do novo

\footnotetext{
${ }^{286}$ MARTINS, Sergio Pinto. Consórcio de empregadores rurais, cit., p. 7. A matéria não é pacífica nos tribunais, podendo-se colher decisões que reconhecem tal invasão de competência, e as que não enxerga tal invasão, garantindo ao Auditor-Fiscal do Trabalho a atribuição de verificar a existência do vínculo de emprego. Conforme notícia publicada no site oficial do Tribunal Superior do Trabalho (www.tst.jus.br) em 04/06/2010, a Sexta Turma daquele Tribunal reconheceu a atribuição do Auditor-Fiscal do Trabalho para declarar a existência do vínculo empregatício, sem que isso signifique invasão da competência do Poder Judiciário (RR 131140-48.2005.5.03.0011).

${ }^{287}$ LEMES, Viviane Aparecida. op. cit., p. 77-78: "a formação do grupo exige um longo processo de planejamento e de negociação dos interesses, cuja natureza mantém uma estreita relação com o tamanho das propriedades, o tipo de exploração realizada e o número de trabalhadores necessários. (...) A formação do grupo requer necessariamente um longo período de reuniões em que os interesses e as divergências que ocorrerem entre os futuros associados sejam amplamente debatidas e negociadas. Nesse processo, o estabelecimento de relações de confiança entre os produtores - construída ao longo de anos de trabalho conjunto em associações, sindicatos rurais, cooperativas agrícolas, entre outros - tem enorme importância para a consolidação do consórcio, pois, é justamente essa confiança recíproca que dará aos empregadores a certeza de que cada um honrará com seus compromissos".

${ }^{288}$ Observa-se que o consórcio não precisa ser formado por produtores que cultivem o mesmo produto agrícola. Não há qualquer restrição para que se unam como consorciados produtores de culturas diversas, o que poderia, inclusive, contribuir para o rodízio dos empregados entre as propriedades, considerando os diferentes períodos de safra. Sendo diferentes os produtos, minimiza-se a possibilidade de concorrência entre os consorciados.
} 
modelo de contrato, levando-se em consideração as peculiaridades de cada produtor, como o tamanho da propriedade, a quantidade e natureza do bem produzido, o número de trabalhadores necessários, entre outras, ressaltando-se o compromisso de cada um com o cumprimento da legislação trabalhista.

A fim de diminuir o impacto negativo possivelmente representado pela responsabilidade solidária, nada impede a determinação, no próprio pacto de solidariedade, de penalidades para aquele que der causa a prejuízos aos demais consorciados, além da esperada responsabilidade em competente ação de regresso. Eventual previsão de multa, ou até mesmo exclusão do consórcio, desestimularia o descumprimento das obrigações trabalhistas e previdenciárias, e poderia aumentar a confiança entre os produtores. Teria melhores efeitos práticos, ajudando na clareza para todos, que tal penalidade fosse prevista em um anexo, mantendo isolada no documento principal a questão da responsabilidade solidária. Nesse anexo, levado também a registro, poderiam ser tratadas outras questões de interesse dos consorciados. Observamos ser o pacto de solidariedade um acordo de vontades, ainda que com conteúdo mínimo previsto normativamente. Como acordo de vontades, tolera as cláusulas que os interessados pretenderem, salvo as expressamente proibidas ou incompatíveis com o conteúdo mínimo legalmente exigido.

Por outro lado, um aspecto a ser levado em conta é que a redução dos custos proporcionada pelo consórcio poderia levar, a médio e longo prazos, a um desequilíbrio no mercado em prol dos produtores consorciados. Com custos mais baixos, os consorciados poderiam obter maiores lucros e certo destaque no mercado. A partir da percepção geral de que o consórcio estaria produzindo bons resultados, haveria então um movimento natural no mercado de atração para o consórcio, criando nos demais produtores o interesse em ingressar naquele consórcio $^{289}$. Isso poderia, em tese, relegar a segundo plano a necessidade de alto grau de confiança entre os contratantes. No entanto, não seria recomendável que o consórcio permitisse a entrada indiscriminada de produtores, sem se atentar minimamente para a idoneidade financeira dos novos consorciados. Afinal, a solidariedade continuará a prevalecer, já que o novo integrante passará a constar do pacto de solidariedade, assim como os demais.

Além do pacto de solidariedade, a Portaria 1.964/99 exige a documentação própria da administração do consórcio, inclusive outorga de poderes a um dos consorciados, ou

\footnotetext{
${ }^{289}$ Como será visto adiante, (fls. xx) a adesão de produtores rurais a consórcio pré-existente não é algo incomum.
} 
gerente/administrador, para contratar e gerir a mão de obra. Depreende-se que os produtores rurais, ao se associarem, transferem a uma só pessoa poderes para o exercício da administração da mão de obra. Tal transferência se faz necessária como instrumento para efetiva implantação do consórcio. Deve haver centralização do comando, que terá visão geral sobre as necessidades de todos os consorciados, viabilizando a contratação do número necessário e suficiente de trabalhadores e da colocação destes em cada uma das diversas propriedades, nos momentos mais adequados para todos. Eventuais divergências entre os produtores consorciados a respeito do número de empregados a contratar, ou da época melhor para a contratação, ou da alocação dos trabalhadores nesta ou naquela propriedade, entre outras, são minimizadas com a transferência do poder de tomar tais decisões para um centro de comando único.

Viviane Aparecida Lemes ${ }^{290}$ enxerga essa transferência de poder como transferência de parte da própria subordinação jurídica, afirmando que com a outorga de poderes ao administrador/gerente, o produtor abriria mão também do poder fiscalizatório e disciplinar. Deve-se observar tal afirmação com ressalvas. De fato, não se percebe na doutrina ou na legislação pertinente obrigatoriedade de se transferir ao gerente do consórcio a totalidade do poder diretivo, podendo determinada parcela sua permanecer com cada produtor rural. É plenamente viável cada produtor rural conservar inclusive o poder de fiscalizar e de aplicar penalidades aos empregados enquanto estes se ativarem na sua propriedade, desde que exercidos tais poderes, logicamente, dentro do que permite o ordenamento. Poderá haver, então, situações em que cada produtor rural conserve o poder de fiscalizar o trabalho executado na sua propriedade, bem como o poder de ordenar a aplicação de punições disciplinares aos trabalhadores que lá se ativarem.

O poder diretivo, desse modo, se apresentaria dividido entre o gerente do consórcio e o produtor consorciado, cabendo ao primeiro questões de ordem genérica e operacional, como a contratação e dispensa dos empregados, elaboração da folha de pagamento, aquisição e distribuição de equipamentos de proteção individual, alocação dos

\footnotetext{
${ }^{290}$ Nas palavras da autora: "nos consórcios de empregadores rurais é interessante observar a questão da subordinação jurídica no contrato de trabalho. Isso porque a determinação das condições para a utilização e aplicação concreta da força de trabalho do empregado, bem como a verificação do exato cumprimento da prestação de trabalho e a aplicação de penas disciplinares, em caso de inadimplemento, não são feitas diretamente pelos empregadores que constituíram o consórcio, mas sim, pelo responsável pelo consórcio, que recebe uma procuração, outorgada por instrumento público, de cada um dos produtores, com amplos poderes de gestão e administração da mão de obra contratada, responsabilizando-se pelo gerenciamento da mão de obra (admissão, demissão, distribuição dos trabalhadores, etc.) pelas diversas propriedades que compõem o consórcio.” LEMES, Viviane Aparecida. op. cit., p. 68.
} 
trabalhadores nas diversas propriedades e a determinação genérica do como proceder durante o trabalho, com regras gerais e invariáveis de estabelecimento para estabelecimento, já que o contrato é único; e ao segundo poderia caber a determinação de alguns detalhes da prestação dos serviços, detalhes estes vinculados por exemplo ao produto cultivado especificamente naquela propriedade ${ }^{291}$; poderia caber também o poder de fiscalização do trabalho e a possibilidade de aplicar punições disciplinares aos trabalhadores. Um colhedor de laranja que deixa para trás alguns frutos, por exemplo, deve ser orientado a realizar melhor a sua tarefa pelo produtor rural da propriedade em questão, pois esse produtor integra a figura do empregador por equiparação Consórcio de Empregadores Rurais, mantendo consigo o poder diretivo, que não desaparece nem se desloca necessariamente para o gerente, detentor de poderes de gestão. É de interesse único e específico daquele produtor a eficiência da colheita em seu pomar. Lembre-se que cada consorciado conserva a sua unidade econômica, podendo estar em situação de concorrência com os demais no mercado. A possibilidade de fiscalizar a execução das tarefas na própria lavoura é, portanto, importante para que o produtor rural possa garantir seu lucro. A ausência dessa possibilidade poderia inclusive minar a confiança do produtor no próprio sistema do consórcio.

Vislumbram-se as duas possibilidades: tanto pode o administrador exercer o poder diretivo integralmente, como cada produtor rural conservar consigo uma parcela desse poder, a ser exercido quando a mão de obra se ativar no seu estabelecimento, restando ao gerente/administrador apenas a gestão da mão de obra. Isso porque a portaria se refere a um documento em que se outorgam poderes para "contratar e gerir a mão de obra" (inciso III do art. $3^{\circ}$ ). Não se fala em contratar e "comandar", ou "subordinar" a mão de obra, mas simplesmente "gerir".

A opção por transferir ao gerente o poder diretivo na íntegra apresenta-se viável, pois o acordo de vontade entre os produtores permite qualquer cláusula que não afronte o ordenamento ou a natureza do instituto. Imagina-se a hipótese em que, por herança, vários irmãos recebem, cada um, uma propriedade rural. Apenas um deles possui experiência nesse meio, todos os outros jamais foram empregadores ou tiveram alguma experiência no campo. Eles decidem então formar um consórcio de empregadores rurais, para reduzir os custos. Essa situação exemplifica um caso em que seria proveitosa a transferência, pelo

\footnotetext{
${ }^{291}$ Respeitadas, obviamente, as regras pertinentes às alterações do contrato de trabalho, artigos 468 e seguintes da CLT.
} 
menos a princípio, de todo o poder diretivo para o produtor mais experiente, escolhido para gerenciar o consórcio.

Tais questões (relativas ao exercício do poder diretivo) podem ser debatidas durante as tratativas para a criação do consórcio, podendo inclusive figurar em um documento escrito. De qualquer modo, quanto mais claras ficarem as regras de funcionamento do consórcio, maior será a segurança e tranquilidade para os consorciados. Outras questões podem constar de documento escrito. Pode-se citar, por exemplo, a definição de critérios objetivos para a distribuição dos trabalhadores, definindo quais propriedades serão atendidas prioritariamente pela mão de obra, evitando que o arbítrio do administrador seja absoluto. Não vemos obstáculos para que tais determinações constem de anexo, levado também a registro, resguardando a singeleza do documento principal, em que constaria apenas as questões da reunião para contratação única de mão de obra e da responsabilidade solidária pelas obrigações trabalhistas e previdenciárias, ou seja, o conteúdo mínimo estabelecido pela legislação.

Após a Circular INSS n. ${ }^{\circ} 56$ /99 e a Portaria MTE n. ${ }^{\circ}$ 1.964/99, a Lei n. ${ }^{\circ}$ 10.256/01 veio alterar a Lei 8.212/91, passando a equiparar o consórcio de empregadores rurais a empregador rural pessoa física ${ }^{292}$. Passou a existir, então, lei em sentido estrito reconhecendo a existência jurídica do consórcio de empregadores rurais e lhe conferindo a qualidade de empregador por equiparação, garantindo também a responsabilidade solidária previdenciária. A lei n. ${ }^{\circ}$ 10.256/01 repete alguns dos requisitos estabelecidos nas normas acima citadas. Verificadas as principais características do consórcio estabelecidas normativamente, passamos a analisar a denominação do instituto.

\footnotetext{
${ }^{292}$ Após a lei 10.256/01, a Lei n. ${ }^{\text {8 }}$ 8.212/91 passou a contar com o artigo 25-A, com a seguinte redação: "Art. 25A. Equipara-se ao empregador rural pessoa física o consórcio simplificado de produtores rurais, formado pela união de produtores rurais pessoas físicas, que outorgar a um deles poderes para contratar, gerir e demitir trabalhadores para prestação de serviços, exclusivamente, aos seus integrantes, mediante documento registrado em cartório de títulos e documentos.

$\S 1^{\mathrm{o}} \mathrm{O}$ documento de que trata o caput deverá conter a identificação de cada produtor, seu endereço pessoal e o de sua propriedade rural, bem como o respectivo registro no Instituto Nacional de Colonização e Reforma Agrária - INCRA ou informações relativas a parceria, arrendamento ou equivalente e a matrícula no Instituto Nacional do Seguro Social - INSS de cada um dos produtores rurais.

$\S 2^{\circ}$ O consórcio deverá ser matriculado no INSS em nome do empregador a quem hajam sido outorgados os poderes, na forma do regulamento.

$\S 3^{\circ}$ Os produtores rurais integrantes do consórcio de que trata o caput serão responsáveis solidários em relação às obrigações previdenciárias.
} 


\subsection{Denominação}

A Portaria MTE n. ${ }^{\circ}$ 1.964/99, no seu "considerando", refere-se à figura utilizando quatro denominações: "condomínio de empregadores", "pluralidade de empregadores rurais", "registro de empregados em nome coletivo de empregadores" e "consórcio de empregadores rurais" 293; e escolhe no artigo $1^{\circ}$ a denominação "Consórcio de Empregadores Rurais". Conforme Sérgio Pinto Martins ${ }^{294}$, o termo “condomínio" é equivocado, pois indica propriedade em comum. Na sequência, o autor critica também o termo "consórcio", utilizado pelo Direito Comercial com outro sentido. Também Nelson Mannrich ${ }^{295}$ apresenta sólidas críticas à utilização dos termos “condomínio" e "consórcio". Faz-se coro com o entendimento dos autores. "Condomínio" é conceito próprio do direito civil, indica a multiplicidade de proprietários de um mesmo bem, a existência de mais de um titular do direito real sobre uma determinada coisa. A importação desta expressão para a figura em questão traz o sério inconveniente de que, no consórcio de empregadores rurais, não há copropriedade. A união dos produtores rurais não gera qualquer reflexo sobre os direitos de propriedade já existentes. Os contratantes não se tornam donos de algo, nem passam a dividir, em função do pacto, a propriedade de algum bem. A única finalidade da união é a contratação única de empregados, para a utilização compartilhada da mão de obra.

Seguindo as observações de Mannrich ${ }^{296}$, a expressão "consórcio de empregadores" também não se mostra tecnicamente adequada, pois o consórcio é conceito próprio do direito comercial, refletindo um tipo de concentração empresarial, conforme capítulo XXII (artigos 278 e 279) da Lei das Sociedades por Ações, Lei n. ${ }^{\circ}$ 6.404/76. Segundo a norma, o consórcio reúne companhias ou outras sociedades para a execução de um determinado

\footnotetext{
${ }^{293}$ Portaria n. ${ }^{1}$ 1.964/99: O MINISTRO DE ESTADO DO TRABALHO E EMPREGO, no uso das atribuições que lhe confere o inciso I do parágrafo único do art. 87 da Constituição Federal, tendo em vista o disposto no art. $7^{\circ}$ dessa Carta e, ainda, considerando a necessidade de orientação aos Auditores-Fiscais do Trabalho quanto à fiscalização em propriedades rurais em que haja prestação de trabalho subordinado a um "Condomínio de Empregadores" (ou "Pluralidade de Empregadores Rurais", ou "Registro de Empregadores em Nome Coletivo de Empregadores", ou "Consórcio de Empregadores Rurais"), RESOLVE:[...]"

${ }^{294}$ MARTINS, Sergio Pinto. Consórcio de empregadores rurais, cit., p. 5.

${ }^{295}$ Nas palavras do autor: "o objetivo do novo sistema é unir produtores rurais com a única finalidade de cumprir a legislação trabalhista, racionalizando os custos e contratando mão-de-obra diretamente, sem qualquer liame com o direito real”. MANNRICH, Nelson. Consórcio de empregadores rurais, cit., p. 396.

${ }^{296}$ MANNRICH, Nelson. Consórcio de empregadores rurais, cit., p. 396-394.
} 
empreendimento, não se presumindo a solidariedade. A lei estabelece o conteúdo do contrato de constituição desse consórcio.

A inadequação é evidente. Ao contrário do consórcio da lei n. ${ }^{\circ} 6.404 / 76$, a união dos produtores rurais é exclusivamente de pessoas físicas, com tratamento previdenciário próprio de pessoa física. Essa é inclusive uma das principais vantagens do consórcio de empregadores rurais, pois a alíquota aplicada às pessoas jurídicas é mais onerosa, praticamente inviabilizando o negócio. A finalidade é a contratação e gestão de mão de obra, e não a execução de um determinado empreendimento. Por fim, o conteúdo do contrato determinado pela Portaria MTE n. ${ }^{\circ}$ 1.964/99 é totalmente diverso do determinado pela Lei 6.404/76, como não poderia deixar de ser.

A denominação sociedade também não se mostra adequada, pois a affectio societatis está evidentemente ausente. A única finalidade é a contratação de empregados, não a união de esforços para a produção comum de um bem ou serviço.

Viviane Aparecida Lemes, afirma que melhor seria utilizar termos como "Consorciação ou União Solidária de empregadores rurais ${ }^{297}$." Entretanto, citando Maurício Mazur, a autora considera a expressão "consórcio" mais "sintética, usual e de fácil lembrança", preferindo utilizá-la em seu trabalho ${ }^{298}$. A maioria da doutrina utiliza a expressão "consórcio de empregadores rurais"299.

Há que se observar a expressão "pluralidade de empregadores rurais", mencionada pela própria portaria n. ${ }^{\circ}$ 1.964/99. Com essa expressão seriam evitadas as inadequações encontradas nas expressões "condomínio" e "consórcio", já que o termo "pluralidade" não está previamente vinculado a qualquer instituto jurídico estranho à relação de emprego. Entretanto, o modelo de contratação busca exatamente fazer com que na relação empregatícia figure como empregador não uma pluralidade de pessoas, mas um único empregador por equiparação, integrado por diversos produtores, responsáveis solidariamente. Apresenta-se, então, inadequada a expressão pluralidade de empregadores, pois, de fato, há um único empregador, que é a união de produtores rurais. A pluralidade de

\footnotetext{
${ }^{297}$ LEMES, Viviane Aparecida. op. cit., p. 72.

${ }^{298}$ A autora se baseia em Maurício Mazur, Consórcio de empregadores rurais: a mais nova forma de contratação de trabalho rural. Curitiba: Juruá, 2003. p. 45.

${ }^{299}$ Além de Nelson Mannrich, a própria Viviane Ap. Lemes, Sérgio Pinto Martins e Maurício Mazur, podemos citar, entre outros: FONSECA, Ricardo Tadeu Marques da. op. cit., p. 95-100. PIRES, Aurélio. Consórcio de empregadores rurais, cit., p. 1209-1211. FERRARI, Irany. Uma alternativa para a contratação de mão-de-obra rural: consórcio de empregadores no meio rural. LTr: suplemento trabalhista, São Paulo, v. 35, n. 148, p. 785-787, 1999.
} 
empregadores é justamente o que o consórcio, reconhecido legalmente como empregador por equiparação, busca evitar.

Há outra expressão mencionada pela portaria, "registro de empregados em nome coletivo de empregadores." Tal denominação, além de ser demasiado extensa, privilegia um aspecto administrativo, o registro de empregados, em detrimento do que realmente é a união dos produtores rurais. O registro de empregados, a fuga da informalidade, aumentando a proteção social do trabalhador, indubitavelmente é importante aspecto do modelo, sendo inclusive seu objetivo estampado na própria Circular INSS n. ${ }^{\circ} 56$. No entanto, um determinado instituto deve ser chamado pelo que é, não pelo seu objetivo.

Uma possível denominação, preocupada com a concisão, seria "Contrato de Empregador Rural Coletivo". Esta denominação destaca o que em primeiro lugar e de mais importante acontece para o nascimento da figura: o acordo de vontades. É necessário que os produtores rurais, no início, tenham vontade de se unir para gerenciar a mão de obra, acordem suas vontades, contratem a formação do consórcio. O pacto de solidariedade nada mais é que o instrumento formal desse acordo de vontades, ou seja, desse contrato, ${ }^{300}$ mesmo este tendo o conteúdo mínimo determinado pela legislação.

Sérgio Pinto Martins ${ }^{301}$ é claro ao observar a natureza jurídica do instituto: “ $O$ consórcio é um contrato, um pacto de solidariedade entre os produtores rurais". Os diversos produtores rurais, a fim de reduzirem custos da contratação e gerenciamento dos trabalhadores, decidem, por vontade própria, formar uma união, uma administração centralizada dessa mão de obra, com responsabilidade solidária. Trata-se eminentemente de um acordo de vontades, que irá gerar obrigações e direitos para os acordantes, ou seja, um contrato. Não se percebe qualquer óbice, portanto, para que assim seja chamado. Este acordo de vontades entre os produtores rurais tem como única finalidade a formação de um sujeito, um ente coletivo, já que formado pela coletividade dos contratantes, que os irá representar em um dos polos de um segundo contrato, o contrato de emprego. Ou seja, a característica marcante deste novo tipo de contrato é justamente permitir que figure como um único empregador uma coletividade de pessoas. Parece-nos, desse modo, apropriada a denominação Contrato de Empregador Rural Coletivo. Conforme Sérgio Pinto Martins, o

\footnotetext{
${ }^{300}$ Dorothêe Susanne Rüdiger também enxerga no consórcio de empregadores rurais uma base contratual. RÜDIGER, Dorothêe Susanne. Da gambiarra à conexão em rede: problemas teóricos jurídicos do consórcio de empregadores rurais como empregador único. In: GIORDANI, Francisco Alberto da Motta Peixoto; MARTINS, Melchíades Rodrigues; VIDOTTI, Tarcio José (Coords.). Direito do trabalho rural: homenagem a Irany Ferrari, cit., p. 86-98.

${ }^{301}$ MARTINS, Sergio Pinto. Consórcio de empregadores rurais, cit., p. 6.
} 
âmbito de aplicação da Portaria 1.964 está restrito à área rural, pois ela foi idealizada e criada para essa finalidade. Entendemos prudente, portanto, inserir o termo "Rural" na denominação ${ }^{302}$.

Entretanto, o presente trabalho deve respeitar o leitor, já habituado desde 1999 ao termo "consórcio", eleito pela Portaria 1.964/99. Deve-se levar em consideração também a aceitação do "consórcio" tanto pela maioria da doutrina como pelos atores sociais diretamente envolvidos, já que é corriqueiro, entre os pactos de solidariedade encontrados, verificar-se a expressão "consórcio de empregadores rurais". Aceita-se, pois, utilizar no presente trabalho a expressão "consórcio de empregadores rurais”, por já estar consagrada.

\subsection{Análise crítica}

Em que pese a relevância que a denominação de um determinado instituto possui, mais importante que isto é o entendimento completo do instituto, para que possa ser inclusive aperfeiçoado ${ }^{303}$. Para tanto, cabe agora analisarmos os aspectos positivos e negativos, ou vantagens e desvantagens, identificáveis na utilização do instituto.

Para o empregado, a inovação mais evidente que o consórcio de empregadores rurais apresenta é a possibilidade de o trabalhador, ao não ser mais necessário em uma determinada propriedade, poder trabalhar em outra, em benefício de outro produtor rural, sem o término daquela relação de emprego e início de uma outra. Para o empregado, portanto, a manutenção do vínculo empregatício por um longo período, com o respeito à legalidade que lhe assegura inclusive direitos previdenciários, é a grande vantagem. Ele deixa de sofrer a insegurança de se ver desempregado e à procura de emprego, sempre que não houver mais serviço na propriedade em que estava originalmente trabalhando. Essa vantagem para os empregados, que salta aos olhos, é acompanhada de outras, apontadas pela doutrina. Sérgio Pinto Martins ${ }^{304}$ identifica as seguintes vantagens: a) regularização dos contratos de trabalho, reduzindo a informalidade; b) maior proteção ao trabalhador,

\footnotetext{
${ }^{302}$ Há doutrinadores, no entanto, que entendem ser possível aplicar o conceito ao meio urbano também. Certamente, a ideia é louvável, mas seriam necessários os ajustes apropriados para o novo contexto. Podese citar, por exemplo, FONSECA, Ricardo Tadeu Marques da. op. cit., p.100.

${ }^{303}$ Concorda-se, nesse ponto, com Nelson Mannrich: "Embora a denominação de um determinado instituto seja fundamental (...) enquanto não se consagrar uma ou outra, na falta de uma denominação original, o mais importante é o aperfeiçoamento do sistema". MANNRICH, Nelson. Consórcio de empregadores rurais, cit., p. 396.

${ }^{304}$ MARTINS, Sergio Pinto. Consórcio de empregadores rurais, cit., p. 6.
} 
que passa a ter os mesmos direitos de qualquer empregado; c) continuidade da relação, passando o trabalhador a ficar mais tempo amparado pela relação de emprego, inclusive na entressafra; d) possibilidade de o trabalhador se fixar em um local, já que não será obrigado a procurar emprego em locais distantes; e) oferecimento ao trabalho de melhor estrutura de trabalho, com melhores condições de segurança e saúde e insumos para a produção, oferecidas pelo consórcio.

Marco Antonio Cesar Villatore ${ }^{305}$ constrói um quadro indicativo das vantagens e desvantagens, para empregados, empregadores e terceiros, e aponta os seguintes benefícios aos trabalhadores: a) formalização dos empregos; b) indeterminação do prazo contratual; c) segurança jurídica e garantia legal, levando em consideração a maior capacidade de solvência durante o contrato e em uma possível ação reclamatória; d) isonomia salarial, inclusive com os empregados de cada empregador rural; e) possibilidade de fixação de residência, diminuindo a migração e o risco de agenciamento e aliciamento; f) possibilidade de manutenção da família em local próximo à prestação dos serviços, em razão da predeterminação dos locais onde serão executadas as tarefas; g) proteção à saúde do empregado rural, pois os equipamentos de proteção individual serão fornecidos pela administração do consórcio e h) todo e qualquer direito previdenciário.

Há que se observar, no item "g”, que a proteção à saúde dos empregados rurais não se traduz apenas no fornecimento dos equipamentos de proteção individual pela administração do consórcio. Além disso, tendo a administração do consórcio capacidade econômica mais robusta, em função da união dos consorciados, haverá de conseguir custos mais baixos na aquisição de equipamentos e materiais, assim como na contratação de empresas especializadas para a elaboração de documentos de gestão de segurança e saúde, como os preconizados pela Norma Regulamentadora n. ${ }^{\circ}$ 31. Em suma, a gestão centralizada da mão de obra terá, como um todo, custos menores do que se os empregados estivessem pulverizados entre os diversos produtores, cada um destes tendo que gerir, sozinho, situações como a elaboração de exames médicos, aquisição e guarda de material de primeiros socorros, e todas as providências exigidas pela NR 31. O ganho na proteção à saúde e segurança dos empregados será, portanto, alcançado como um todo, em função da redução do custo das medidas necessárias, e não apenas no fornecimento de equipamentos de segurança individual. A redução do risco de não ser registrado, da informalidade, reduz

${ }^{305}$ VILLATORE, Marco Antonio César. op. cit., p. 435 e 453-454. 
consequentemente o risco do desamparo total no caso de um infortúnio, pois os direitos previdenciários estarão assegurados.

A doutrina ${ }^{306}$ aponta de maneira semelhante as vantagens, ou aspectos positivos, do Consórcio para os empregados.

Com o reconhecimento da Lei . $^{\circ}$ 10.256/01, o consórcio passa a poder ser considerado empregador, ainda que por equiparação. Ele é o verdadeiro empregador, não cada produtor rural. A partir disso, pode-se indicar uma solução para os chamados "boias frias", os trabalhadores eventuais do campo. Afirmava Sérgio Pinto Martins ${ }^{307}$ em 2000, antes da edição da referida Lei, que muitas vezes o empregado presta serviço um dia para a pessoa física $\mathrm{A}$, no dia seguinte para a pessoa física $\mathrm{B}$, no terceiro dia para $\mathrm{C}$, e assim por diante. Não poderia haver relação de emprego, já que, com cada produtor rural haveria, em verdade, a descontinuidade na prestação dos serviços. Estaria ausente a continuidade ou não eventualidade, um dos requisitos essenciais da relação de emprego. Entretanto, após a edição da referida lei, caso as pessoas físicas A B e C sejam integrantes de um consórcio, faz-se presente o requisito da não eventualidade perante o consórcio, podendo-se concluir pela existência da relação de emprego não com cada produtor, mas com o consórcio em si. Trata-se de uma hipótese de tutela para esse tipo de trabalhador, que passaria a poder gozar da rede de proteção trabalhista e previdenciária, que lhe faz tanta falta.

Para os empregadores também há benefícios evidentes, como a redução dos custos que a gestão unificada representa. Ademais, economiza-se o gasto de cada produtor com o

\footnotetext{
${ }^{306}$ Pode-se citar, entre outros: Nelson Mannrich indica o registro em CTPS, afastando a informalidade e atravessadores, como cooperativas fraudulentas; a garantia dos direitos trabalhistas, já que todos os produtores respondem solidariamente; saúde e segurança, pois há maior controle por parte do Ministério do Trabalho e Emprego e do próprio Ministério Público do Trabalho. MANNRICH, Nelson. Consórcio de empregadores rurais, cit., p. 395. Ricardo Tadeu Marques da Fonseca aponta que o consórcio constitui "figura típica de flexibilização trabalhista, a qual, todavia, não precariza a condição do trabalhador, propiciando, ao contrário, distribuição de renda e dignidade às relações entre capital e trabalho". FONSECA, Ricardo Tadeu Marques da. op. cit., p. 100. Aurélio Pires afirma: "segundo os laboralistas rurais, o Consórcio não é só um benefício ao empregado, mas também um meio de proporcionar-lhe segurança, contratado, que é, por diversos empregadores. Benefícios, porque o registro lhe assegura não só o emprego, mas também todas as vantagens dele decorrentes, inclusive de natureza previdenciária. Segurança porque regularizado, livre de marginalidade do trabalho informal, passa a possuir um referencial, qualitativo, em seu meio social". PIRES, Aurélio. Consórcio de empregadores rurais, cit., p. 1211. Viviane Aparecida Lemes aponta também a formalização, com a garantia dos direitos previdenciários e fundiários, aumentando a chance de se tornar contínua a relação de emprego, em virtude do constante rodízio entre os produtores; o aproveitamento da mão de obra do trabalhador em diversas culturas e safras no decorrer do ano; redução da migração; maior segurança jurídica, com a garantia de todas as verbas trabalhistas e o afastamentos de terceiros ou intermediários, e a responsabilidade solidária dos produtores, facilitando o recebimento de eventuais créditos. LEMES, Viviane Aparecida. op. cit., p. 81-82.

${ }^{307}$ MARTINS, Sergio Pinto. Consórcio de empregadores rurais, cit., p. 6.
} 
rompimento do contrato de trabalho sucessivas vezes. A racionalização dos custos, o melhor gerenciamento dos gastos, é a vantagem que mais salta aos olhos.

Além disso, o contrato de trabalho mais prolongado permitirá ao empregador, no caso a administração do consórcio, conhecer melhor seus empregados, podendo incentivar os melhores e orientar ou corrigir os menos produtivos, de maneira a extrair do mesmo corpo de empregados uma produtividade maior ao longo do tempo. Marco Antonio César Villatore $^{308}$ indica as seguintes vantagens aos produtores rurais: a) formalização de contratos com prestadores de serviços para casos especiais, conforme agendamento perante a administração do consórcio; b) pagamento dos salários e de todos os encargos dividido e proporcional à utilização da mão de obra; c) manutenção desta proporção no momento da rescisão contratual com os empregados (ressalvado, evidentemente, o caso de haver alguma controvérsia, quando poderá gozar o empregado de seu direito de exigir de qualquer um dos consorciados o total da dívida); d) desburocratização nas formalizações dos contratos dos empregados, além das formalizações gerais junto ao INSS (acredita-se ser esta uma das principais vantagens. Por exemplo, haverá apenas um contrato a ser informado ao CAGED e à RAIS, ao invés dos diversos e sucessivos contratos que precisariam ser informados por cada produtor rural).

O autor segue sua lista ${ }^{309}$ : e) estrutura comum de gerenciamento dos empregados, inclusive podendo fornecer experiência aos produtores rurais no gerenciamento de seus empregados individuais; f) formalização de CEI referente à pessoa física, conforme

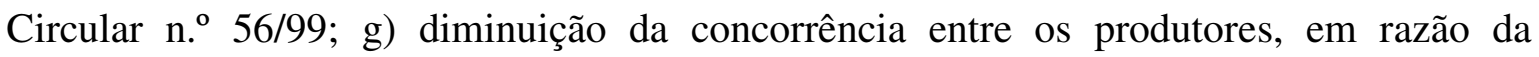
isonomia salarial ditada pelos membros do consórcio (neste aspecto, é importante frisar que se reduz o risco de que um determinado produtor, ao contar com mão de obra informal, concorra de maneira desleal com os demais, ou seja, diminui-se o risco de a concorrência entre os produtores gerar efeitos maléficos aos trabalhadores), e h) facilidade de negociação e de formalização de acordo coletivo de trabalho junto às entidades sindicais da categoria (observamos, aqui, que um dos problemas do consórcio de empregadores diz respeito justamente à negociação coletiva, como será visto adiante). O autor, com seus apontamentos, abarca grande parte das vantagens para os empregadores apontadas pela doutrina ${ }^{310}$.

\footnotetext{
${ }^{308}$ VILLATORE, Marco Antonio César. op. cit., p. 436-437.

${ }^{309}$ Id. Ibid., p. 436-437.

${ }^{310}$ Podemos citar, entre outros: Nelson Mannrich afirma que "O empregador rural também é beneficiado, não só pela redução de custo e racionalização do serviço prestado, como pela maior segurança jurídica que esta modalidade oferece, livrando-o da informalidade que tanto o fragiliza”. MANNRICH, Nelson. Consórcio de empregadores rurais, cit., p. 395.
} 
O consórcio de empregadores rurais apresenta vantagens também para o Estado, ganhando toda a sociedade, pois a redução da informalidade contribui com a Previdência Social e o FGTS, cujos recursos são utilizados, por exemplo, em saneamento básico. A proteção à saúde e segurança dos trabalhadores reduz o número de acidentes e doenças profissionais, desonerando tanto o INSS como o SUS. Enfim, a utilização do consórcio de empregadores rurais, aumentando a formalidade no campo, traz consigo todos os benefícios que a redução da informalidade representa, para toda a sociedade.

Entretanto, o consórcio de empregadores rurais apresenta também alguns aspectos negativos, ou desvantagens. Para os empregados, é difícil encontrar alguma desvantagem. O consórcio, indubitavelmente, estimula a formalização do vínculo empregatício, o que representa vantagens ao empregado. Somente aquele trabalhador que pretende fraudar o Seguro Desemprego ou o FGTS, ou aquele que tenta fugir a obrigações alimentares, ou ainda aquele que busca a remuneração imediata maior, somente possibilitada pelos custos menores da informalidade, apenas estes poderiam se ver prejudicados com o estimulo à formalização do vínculo empregatício. Na doutrina pesquisada não se encontra qualquer indicação de desvantagem ao trabalhador.

No campo teórico, interessantes são as observações de Dorothêe Susanne Rüdiger $^{311}$, que compara o consórcio de empregadores rurais a uma "gambiarra". Afirma a pesquisadora que o consórcio representa solução criativa, apoiando-se em "laços de vizinhança" para estabelecer "vínculos estáveis de trabalho", conectando os trabalhadores à "rede de benefícios trabalhistas e previdenciários". Essa ligação, todavia, seria marcada pela fragilidade jurídica, carecendo de solidez no seu fundamento legal e de sustentação teórica satisfatória. O consórcio sofreria também com uma contradição marcante, pois não constitui uma pessoa, mas é empregador, ou seja, é "tratado como se pessoa fosse".

Afirma então a autora ${ }^{312}$ que o fundamento para considerar o consórcio como empregador único seria uma analogia à figura do grupo de empresas previsto no artigo $3^{\circ}$, $\S 2^{\circ}$ da Lei n. $^{\circ} 5.889 / 73^{313}$. A diferença principal seria a de que no consórcio de empregadores rurais as pessoas reunidas concorrem entre si no mercado, sendo marcante a

\footnotetext{
${ }^{311}$ RÜDIGER, Dorothêe Susanne. op. cit., p. 87-88.

${ }^{312}$ Id. Ibid., p. 89.

${ }^{313}$ Observa-se a ressalva de que o grupo de empresas previsto na legislação será constituído por empresas, com personalidade jurídica, e o consórcio de empregadores rurais é exclusivamente formado por pessoas físicas. Essa diferença é ressaltada por: MANNRICH, Nelson. Consórcio de empregadores rurais, cit., p. 395.
} 
contradição entre a solidariedade e a concorrência. Conclui a autora ${ }^{314}$ que o consórcio pode ser considerado uma

"solução prática para um problema social. No entanto, a contradição entre a manutenção das personalidades e do patrimônio distintos de cada um dos consorciados e a união para a consecução de determinados interesses dificulta a conceituação enquanto empregador único.”

De fato, considerando que os instrumentos normativos iniciais do consórcio de empregadores rurais eram uma Portaria e uma Circular, não havia base legal sólida a sustentar o consórcio de empregadores rurais. Entretanto, a Lei n. ${ }^{\circ}$ 10.256/01 equiparou o consórcio a empregador rural pessoa física. Ou seja, já há uma solidez maior no alicerce normativo do modelo contratual.

O consórcio não constitui uma pessoa jurídica. Entretanto, mesmo nessas condições, o consórcio é considerado pela legislação como um empregador único, pois é o nome de um dos consorciados, seguido da expressão "e outros", que deve constar na CTPS e no registro administrativo do contrato de emprego a que se refere o artigo 41 da CLT. Após a edição da Lei n. ${ }^{\circ}$ 10.265/01, o consórcio é legalmente empregador por equiparação. Rüdiger explica o consórcio enquanto empregador negando a equiparação, se valendo do conceito de rede ${ }^{315}$. O consórcio seria uma estrutura com sujeito jurídico independente de sua personalidade. Essa estrutura seria empregadora "não por lei nem por equiparação, mas por "direito próprio"”, a partir da rede contratual. O vínculo entre os produtores constituiria um corpo social e um ente jurídico, o empregador.

Nelson Mannrich ${ }^{316}$, por seu turno, afirma:

"Empregador é toda entidade empresarial e respectiva organização que se utiliza de empregados. Nesse conceito é possível enquadrar o empregador rural, tanto a pessoa física quanto a jurídica ou qualquer ente dotado ou não de personalidade jurídica, que explore uma atividade rural com o auxílio de empregados. Quando diversas pessoas físicas, na qualidade de produtores rurais, organizam-se para contratar diretamente empregados e com isso eliminar o trabalho informal e/ou o intermediador de mão de obra, não há necessidade de lei especial para qualificá-los de empregador; o art. $3^{\circ}$ da Lei n. ${ }^{\circ} 5.889 / 73$ é suficiente".

\footnotetext{
${ }^{314}$ RÜDIGER, Dorothêe Susanne. op. cit., p. 89.

${ }^{315}$ Id. Ibid., p. 95.

${ }^{316}$ MANNRICH, Nelson. Consórcio de empregadores rurais, cit., p. 395.
} 
De fato, há contradições no instituto, não evitadas no momento da sua criação, mas de efeitos práticos que não se apresentam como dificuldades insuperáveis. Não é pelo fato de se tratar de um ente sem personalidade jurídica, mas equiparado a sujeito de direito, que lhe cabe o conceito de figura totalmente estranha ao ordenamento jurídico. $\mathrm{O}$ direito convive com situações desse tipo, podendo ser citado o clássico exemplo do nascituro, que é sujeito de direito, mesmo não tendo personalidade jurídica. O espólio e a massa falida são também exemplos, podendo inclusive serem considerados empregadores. Ademais, o legislador ordinário equiparou a figura ao empregador pessoa física, não se podendo mais negar essa condição ao consórcio, em função do comando legal.

A contradição entre a concorrência no mercado e a conjugação de esforços para um determinado objetivo também não é totalmente estranha ao mundo jurídico. Trata-se de situação que pode perfeitamente existir e dar inclusive bons resultados econômicos para os sujeitos envolvidos. As associações patronais, os "lobbies" políticos de determinados setores da economia, são exemplos de convívio de empresas que, apesar de concorrerem no mercado, atuam de forma conjunta. $\mathrm{O}$ cartel é exemplo disso, figura que é até mesmo combatida pelo direito, haja vista sua eficiência em desequilibrar o mercado em prol dos seus integrantes. A conjugação entre concorrência no mercado e esforços conjuntos não é, portanto, necessariamente uma contradição insuperável. Parece-nos, antes, uma contradição que, apesar de ser inegavelmente presente, é algo suportável pelos atores sociais envolvidos, que calibram suas atitudes conforme os interesses em jogo.

Ademais, a contradição apontada pela autora está presente no próprio artigo $2^{\circ}$ da CLT, que conceitua empregador como "empresa", sendo que nem toda empresa possui personalidade jurídica. A empresa irregular também não é pessoa jurídica, mas é empregador, e tratada como se pessoa fosse. Trata-se de situação tranquilamente aceita dentro do direito do trabalho. A mesma tranquilidade deve se dar com o consórcio de empregadores rurais.

Há que se ter em mente a afirmação de Octávio Bueno Magano ${ }^{317}$, citado pela própria autora: "em verdade, possui a condição de empregador todo ente que se utilize de trabalhadores subordinados". Em outras palavras, para considerar o consórcio de empregadores rurais como empregador não seria necessário o recurso à analogia. A equiparação trazida pela Lei n. ${ }^{\circ}$ 10.256/01 resolve definitivamente a questão, devendo o consórcio ser considerado, ele próprio, o empregador, pois está equiparado a tal. Não se

\footnotetext{
${ }^{317}$ MAGANO, Octávio Bueno. Manual de direito do trabalho: direito individual do trabalho, cit., v. 2 , p. 77.
} 
pode emprestar interpretação literal ao artigo $3^{\circ}$ da Lei 5.889/73 quando este se utiliza do termo "pessoa" para definir empregador. Ainda mais se considerarmos os princípios hermenêuticos próprios do direito do trabalho, atentando para o fato de que o ordenamento jurídico já convive com situações em que o empregador não possui personalidade jurídica.

Com um viés mais voltado para o lado prático, os empregadores podem enxergar outros aspectos negativos. O mais evidente é a assunção de responsabilidade solidária. Houve quem enxergasse nesse fato uma causa de total fracasso do modelo de contratação, como o advogado Carlos Alberto R. Soares de Queiroz ${ }^{318}$, que teceu pesadas críticas ao consórcio em função da solidariedade, que apanharia de surpresa os consorciados na primeira reclamação trabalhista que fosse apresentada. As críticas apresentadas, no entanto, não se mostram sólidas. Primeiramente, após mais de dez anos, o consórcio de empregadores rurais não se mostrou um fracasso total, sendo encontrado entre produtores rurais do interior paulista, por exemplo. Além da experiência prática, desautorizando as críticas, pode-se também afirmar que a solidariedade é resultado de um pacto, ou seja, um acordo de vontades. O consorciado, ao firmar este pacto, tem pleno conhecimento da responsabilidade que assume, não sendo posteriormente apanhado de surpresa. Não é por outra razão que a constituição do consórcio, conforme já visto acima, deve ser precedida de reuniões entre os produtores interessados, com amplo esclarecimento a todos, sendo que os participantes devem se conhecer mutuamente, para haver um determinado grau de confiança suficiente a permitir a constituição do consórcio.

Por outro lado, na hipótese de todos os consorciados possuírem elevado grau de confiança mútua, a solidariedade pode até representar uma segurança a mais para o consorciado, que por razões de força maior, por exemplo, não conseguiu arcar com suas obrigações. Este produtor poderá ter sua dívida alongada no tempo, já que o valor a ser pago imediatamente aos empregados poderá ser diluído entre todos os consorciados, com

\footnotetext{
${ }^{318}$ QUEIROZ, Carlos Alberto Ramos Soares de. Consórcio de empregadores: uma alternativa de risco. RDT: revista do direito trabalhista, v. 6, n. 2, p. 12-13, fev. 2000. Defendendo o cooperativismo, o autor afirma sobre o consórcio: "Não vai dar certo. Ninguém acredita que sua implantação gerará a ilusória empregabilidade. Surgindo a primeira ação reclamatória, julgada procedente, contra o Consórcio, todos os consorciados são solidários no pagamento da indenização e das verbas rescisórias. Aí, aqueles que nada têm a ver com o processo reclamatório, vão perguntar aos demais e à Procuradoria: 'o que eu tenho a ver com isso?' 'Por que sou obrigado a pagar por aquilo que não causei?' 'Se o responsável não tiver condições econômicas para assumir a indenização, pelos problemas que causou, quantos consorciados vão pagar por ele?' Nesse momento, o Consórcio de Empregadores se desmoronará e ninguém quererá continuar a participar desse inviável e perigoso projeto, equivocado, improvisado, precipitado, desenvolvido corporativamente e impingido, principalmente aos produtores rurais pelos Procuradores do Trabalho da $15^{a}$ Região.” Id. Ibid., p. 12.
} 
os quais ele, o real devedor, poderá ter maior chance de negociação para a quitação da dívida.

Ressalve-se que, caso um determinado produtor seja autuado pela Inspeção do Trabalho por utilizar mão de obra sem registro em sua propriedade, essa autuação administrativa não recairá sobre o consórcio, mas sobre aquele produtor rural, nos termos do $\S 2^{\circ}$ do art. $4^{\circ}$ da Portaria 1.964/99. Por fim, a solidariedade também se dará sob o aspecto ativo, ou seja, todos os consorciados poderão exigir dos empregados a prestação dos serviços, respeitando-se apenas a organização que os próprios consorciados estabeleceram, por meio da administração do consórcio.

Outra questão que merece ser observada é a inalterabilidade contratual ${ }^{319}$. Ou seja, os empregados estão sob a égide de um único contrato de trabalho, cuja possibilidade de alteração deve obedecer aos princípios juslaborais. Se em uma propriedade o custo da mão de obra é menor (por exemplo, em função do tipo de terreno, que permite produtividade maior) o que justificaria remuneração menor, mas o consórcio pactuou um salário maior em função do custo geral nas outras propriedades, não haverá possibilidade de se reduzir o salário naquela determinada propriedade. Haverá, então, um prejuízo relativo para os consorciados, pois naquela propriedade o gasto com os trabalhadores ficou maior que o custo economicamente ideal. Trata-se, entretanto, de um ônus com o qual os produtores deverão arcar, mas que raramente serão impeditivos do consórcio.

A questão sindical, bem observada por Nelson Mannrich ${ }^{320}$ e Sérgio Pinto Martins $^{321}$, apresenta-se mais relevante. O problema se coloca quando o território onde os serviços serão prestados equivaler à base territorial não de um único sindicato, mas de dois ou mais. Há que se determinar qual sindicato irá representar os trabalhadores do consórcio, com legitimidade para entabular negociação coletiva e receber as contribuições próprias. Não há, na legislação, indicação de como resolver esta questão. Nelson Mannrich ${ }^{322}$ aponta a saída mediante a intervenção dos atores sociais envolvidos, ou seja, sindicatos e federações. Não caberia, observa-se de pronto, ao Ministério do Trabalho e Emprego definir qual o sindicato a ser considerado, pois não cabe ao Executivo ameaçar a liberdade sindical, por força do inciso I do art. $8^{\circ}$ da Constituição da República, aplicável às organizações sindicais rurais, conforme parágrafo único do mesmo artigo. Levando em

\footnotetext{
${ }^{319}$ A questão é levantada por: MANNRICH, Nelson. Consórcio de empregadores rurais, cit., p. 394. ${ }^{320}$ Id., loc. cit.

${ }^{321}$ MARTINS, Sergio Pinto. Consórcio de empregadores rurais, cit., p. 6.

${ }^{322}$ MANNRICH, Nelson. Consórcio de empregadores rurais, cit., p. 394.
} 
consideração esse princípio da liberdade sindical, é adequada a solução apontada pelo autor: "caberia aos diversos sindicatos envolvidos introduzir cláusulas com o objetivo de apresentar soluções adequadas, principalmente por meio das respectivas federações”. Entretanto, permanece o problema quando as entidades sindicais não apresentarem tal solução. Marco Antonio César Villatore ${ }^{323}$ lembra a ação de consignação em pagamento, para resolver, nesta situação, o problema das contribuições sindicais. Entretanto, resta a dúvida sobre qual convenção coletiva seguir. A diferença de piso salarial, por exemplo, poderia gerar um passivo trabalhista insuportável.

Trata-se, sem dúvida, de questão que merece maior atenção do legislador, para que soluções sejam apontadas, procurando conferir segurança jurídica a quem queira se utilizar do modelo de contratação que tantas vantagens apresenta. Até porque, de todo o examinado, parece possível concluir que o consórcio de empregadores possui mais aspectos positivos que negativos, tanto para empregados como para empregadores, apresentando-se como alternativa interessante, preservando os direitos dos trabalhadores e a viabilidade econômica dos pequenos produtores rurais.

Certamente seria utópico pretender que determinada figura jurídica trabalhista ficasse totalmente imune à criatividade fraudulenta da sociedade. Há que se relatar, não como aspecto negativo, mas indicando a consciência da possibilidade de fraude, as situações ilícitas já encontradas, com desvirtuamento da figura do consórcio de empregadores rurais. Além do desrespeito simples dos requisitos normativos, encontra-se a utilização do consórcio como prestador de serviços a terceiros, funcionando como verdadeiro intermediador de mão de obra: determinado produtor rural "contrata" o consórcio para prestar serviços na sua propriedade. A contratação se formaliza mediante a adesão ao consórcio, com formalização de um contrato em que o produtor rural passa a integrar o grupo pré-existente, aderindo ao pacto de solidariedade. A adesão é levada a registro no mesmo cartório em que foi registrado o pacto de solidariedade, figurando como adendo. Logo após o término dos serviços, formaliza-se novo contrato, novamente registrado, em que o produtor rural se retira do consórcio, limitando sua responsabilidade solidária ao período em que utilizou a mão de obra.

Tal situação, apesar de evidenciar a utilização do consórcio como prestador de serviço, respeita as formas legais. Não existe vedação legal à adesão, sendo plenamente legítimo que determinado produtor rural, entendendo ser a melhor opção, passe a fazer

${ }^{323}$ VILLATORE, Marco Antonio César. op. cit., p. 437. 
parte de um consórcio já existente. E nada impede que ele mude de opinião, resolvendo deixar de fazer parte do consórcio no momento que bem entender. Não se trata de verdadeira violação da lei, mas do espírito ou da natureza do consórcio. Ademais, os direitos dos trabalhadores não sofrem prejuízo algum, sendo mantidos os seus contratos de trabalho com o consórcio e a responsabilidade daquele produtor rural, pelo tempo em que esteve presente no consórcio. A burla está na atuação do consórcio como empresa prestadora de serviço, mas com tratamento previdenciário de pessoa física.

O combate à sonegação previdenciária, nesses casos, certamente enfrenta a dificuldade para se determinar o caráter fraudulento ou legítimo da adesão e posterior abandono daquele produtor rural do consórcio. O estabelecimento em lei de critérios objetivos relacionados a adesão e saída do consórcio poderiam contribuir bastante para tal combate.

Ocorre que, em alguns casos concretos, a adesão constitui inequívoca fraude, havendo casos em que a sua formalização aconteceu na mesma data do início da ação fiscal da Auditoria-Fiscal do Trabalho ${ }^{324}$, embora os serviços estivessem sendo prestados, como constatado pelos fiscais, há algum tempo. Ou seja, o produtor rural contratou o consórcio como fosse este uma empresa prestadora de serviços, porém com custos previdenciários reduzidos e sem assumir a responsabilidade solidária. Caso a AuditoriaFiscal do Trabalho não tivesse visitado sua propriedade, o produtor certamente não teria aderido ao consórcio. A adesão se deu não pela real e verdadeira vontade de participar do ente coletivo correspondente à figura de empregador, mas apenas para tentar dar aparência de legalidade para a sua conduta desviada.

Nesse contexto, os antigos "gatos" ou intermediadores de mão de obra, já começam a perceber a nova maneira de manter sua atividade, agora não mais sob a máscara da cooperativa, imagem tão desgastada, mas como gerentes de consórcios de empregadores rurais que, ao contrário, gozam da simpatia das instituições, sendo inclusive incentivados pelo Ministério do Trabalho e Emprego. Cabe às instituições responsáveis pela defesa da legalidade e do respeito às leis trabalhistas, como Ministério Público do Trabalho, Auditoria-Fiscal do Trabalho e Justiça do Trabalho, estarem atentas aos casos concretos que se lhes apresentem, para coibir e punir de maneira exemplar os casos de fraude, sem, contudo, fomentar preconceitos e posições ideológicas contra a figura jurídica.

\footnotetext{
${ }^{324} \mathrm{Em}$ relatório de inspeção do grupo de fiscalização rural do estado de São Paulo, relata-se a situação, em que o Cartório de Registro de Documentos recebeu o termo de adesão para registro na mesma data do início da fiscalização.
} 
Em resumo, pode-se concluir que o Consórcio de Empregadores Rurais se credencia como importante alternativa para a formalização da relação de trabalho rural de curta duração, reduzindo custos sem macular direitos e, ao contrário do sistema de trabalho avulso, plenamente adaptado às características do meio rural. Entretanto, em função da responsabilidade solidária entre os consorciados, tende a ter sua expansão limitada, por não representar alternativa totalmente segura para os produtores rurais. 


\section{CONTRATO DE TRABALHO RURAL POR PEQUENO PRAZO}

\subsection{Antecedentes}

O Contrato de Trabalho Rural por Pequeno Prazo foi originalmente previsto pela Medida Provisória n. ${ }^{\circ}$ 410, de 28 de dezembro de 2007, que acresceu o artigo 14-A à Lei n. ${ }^{\circ} 5.889 / 73^{325}$. Raquel Pereira Furtado ${ }^{326}$ e Zéu Palmeira Sobrinho ${ }^{327}$ indicam a origem da norma em reivindicação da cúpula da Confederação Nacional dos Trabalhadores na Agricultura - CONTAG, atendida pelo Governo.

$\mathrm{Na}$ exposição de motivos ${ }^{328}$ da medida provisória é reconhecida a histórica exclusão dos trabalhadores rurais do sistema previdenciário, causada pelos expressivos índices de informalidade no campo.

Após fazer referência a algumas tentativas governamentais de se reverter esse quadro, como o Programa de Assistência ao Trabalhador Rural (Pro-Rural) e a própria edição das Leis n. ${ }^{\circ} 8.212$ e n. ${ }^{\circ} 8.213$, ambas de 1991, a exposição de motivos menciona que era esperada uma mudança no comportamento dos empregadores rurais quanto à formalização das relações do trabalho, esperança não concretizada.

Os pequenos produtores rurais e os que trabalham em regime de economia familiar (representados pela CONTAG) são mencionados como carentes de estrutura administrativa mínima a lhes permitir o cumprimento das exigências legais e regulamentares, trabalhistas e previdenciárias, especialmente para serviços de curta duração. Menciona-se também que, apesar dos esforços governamentais para a conscientização dos produtores rurais a respeito da importância da formalização das relações de trabalho rural, pequenos foram os avanços.

O Legislador ${ }^{329}$ aponta, então, o objetivo almejado com a nova figura contratual:“a criação de mecanismos que promovam e facilitem a formalização dos contratos de trabalho

\footnotetext{
${ }^{325}$ Além de introduzir o novo tipo de contrato, a referida medida também tratou da previdência do trabalhador rural e do financiamento agrícola, referindo-se às leis n. ${ }^{\circ}$ 8.213/91 e 11.524/07.

${ }^{326}$ FURTADO, Raquel Pereira. A lei do trabalho rural e a medida provisória n. ${ }^{\circ}$ 410. Justiça do Trabalho, Porto Alegre, v. 25, n. 296, p. 79-82, ago. 2008.

${ }^{327}$ PALMEIRA SOBRINHO, Zéu. O novo contrato de trabalho rural por pequeno prazo. Trabalho em Revista Nacional, v. 26, n. 306, p. 13, jan. 2008.

${ }^{328}$ PRESIDÊNCIA DA REPÚBLICA FEDERATIVA DO BRASIL. EMI 00040 MF - MPS - MTE. Disponível em: <http://www.planalto.gov.br/ccivil_03/_Ato2007-2010/2007/Exm/EMI-40-MF-MPSMTE.htm>. Acesso em: 31 out. 2011.

${ }^{329}$ Conforme exposição de motivos.
} 
envolvendo esses trabalhadores assalariados rurais, em particular, os que trabalham em atividades de curta duração.”

Após pontuar a sazonalidade do trabalho no campo, a exposição de motivos indica

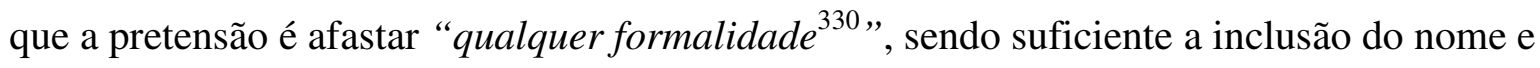
inscrição do trabalhador na Guia de Recolhimento do FGTS e Informações à Previdência Social - GFIP, dispensando-se o registro em livro ou ficha, bem como na Carteira de Trabalho e Previdência Social (CTPS). Os direitos trabalhistas seriam pagos diretamente, incluindo-se na remuneração um percentual referente a férias, adicional de férias, décimo terceiro salário, horas extras, horas in itinere. A contribuição previdenciária, sempre à alíquota de $8 \%$, seria deduzida pelo tomador dos serviços e recolhida no prazo normal e o FGTS seria recolhido conforme a Lei $n .^{\circ}$ 8.036/90. Tais condições seriam válidas apenas para relações não superiores a dois meses no mesmo ano. Superado esse prazo, o contrato se transformaria automaticamente em contrato por prazo indeterminado. Esses os principais aspectos constantes da exposição de motivos.

\subsection{Identificação da figura contratual}

A Lei n. ${ }^{\circ}$ 5.889/73 recebeu, em função da Medida Provisória n. ${ }^{\circ} 410$, de 28 de dezembro de 2007, o acréscimo do artigo 14-A, relativo ao Contrato de Trabalhador Rural por Pequeno Prazo, denominação constante da própria medida provisória. A doutrina ainda não cuidou de conceituar a nova figura contratual, tendo se ocupado principalmente dos seus mais controvertidos aspectos, como a transformação das obrigações de anotar o contrato de trabalho em Carteira de Trabalho e Previdência Social (CTPS) e de registrar o trabalhador em Livro ou Ficha de Registro, previstos nos artigos 29 e 41 da CLT, em meras faculdades ${ }^{331}$.

\footnotetext{
330“ Por esse mecanismo, a contratação para serviços de curta duração, assim entendida aquela com até 2 (dois) meses de duração, poderá ser feita sem qualquer formalidade, bastando apenas que o contratante inclua o nome e a inscrição do trabalhador na Guia de Recolhimento do Fundo de Garantia do Tempo de Serviço e Informações à Previdência Social - GFIP, ficando dispensado do registro no Livro ou Ficha de Registro de Empregados e na Carteira de Trabalho e Previdência Social - (CTPS)”.

${ }^{331}$ Podem ser citados, entre outros, os seguintes artigos doutrinários: FURTADO, Raquel Pereira. op. cit., p. 79-82. GARCIA, Gustavo Filipe Barbosa. Contrato de trabalho rural por pequeno prazo e precarização das relações de trabalho no campo. Revista do Direito Trabalhista, Brasília, v. 15, n. 9, p. 15-17, set. 2009. PALMEIRA SOBRINHO, Zéu. op. cit., p. 13-14. SENA, Natália; OLIVEIRA, Andressa Batista de. Contrato de trabalho rural por pequeno prazo - Lei n.11.718/08 - um convite à fraude. LTr: suplemento trabalhista, São Paulo, ano, 44, n. 105, p. 521-524, 2008.
} 
O contrato por pequeno prazo pode ser conceituado como o contrato por prazo determinado mediante o qual produtor rural, pessoa física, contrata empregados rurais para atividades de natureza temporária, por prazo não superior a dois meses, no período de um ano, sendo permitido ao empregador escolher entre cumprir os artigos 29 e 41 da CLT (anotação em Carteira de Trabalho e Previdência Social e registro em Livro ou Ficha de Registro de Empregados), ou providenciar a formalização escrita do contrato, com conteúdo mínimo estabelecido na legislação, sempre com a inscrição do nome do trabalhador em GFIP.

A conceituação acima leva em consideração alguns aspectos importantes do novo tipo contratual, como natureza necessariamente temporária das atividades contratadas, característica que justifica a determinação de prazo para o contrato laboral ${ }^{332}$. Também a natureza empregatícia da relação estabelecida entre o produtor rural e o trabalhador e, por fim, a consideração da inclusão do nome do trabalhador em GFIP como elemento essencial do novo tipo contratual. No decorrer do presente trabalho ficará demonstrado serem estas características intrínsecas ao contrato por pequeno prazo, que o definem e conceituam.

\subsection{Bases normativas e principais características}

A Medida Provisória refletiu as intenções da exposição de motivos, acrescentando à Lei n. ${ }^{\circ} 5.889 / 73$ o artigo 14-A, com nove parágrafos. Mais $\operatorname{tarde}^{333}$, a medida foi convertida na Lei n. ${ }^{o}$ 11.718/08, com alteração de alguns dispositivos e inclusão um parágrafo. A seguir, o caput e cada parágrafo do artigo 14-A, como ficaram após a conversão em lei, serão analisados.

O novo artigo 14-A apresentou o seguinte caput:

Art. 14-A. O produtor rural pessoa física poderá realizar contratação de trabalhador rural por pequeno prazo para o exercício de atividades de natureza temporária.

\footnotetext{
${ }^{332}$ Art. 443, § 2०, alínea "a" da CLT.

${ }^{333}$ Antes de ser convertida em lei a medida provisória teve sua vigência prorrogada por sessenta dias, por ato do Presidente do Senado Federal, conforme $\S 7^{\circ}$ do art. 62 da Constituição da República, com redação dada pela Emenda Constitucional n. ${ }^{\text {o } 32 / 01 . ~}$
} 
O disposto no caput do novo artigo 14-A trouxe uma faculdade, uma permissão para a utilização da nova figura contratual, empregando a expressão "poderá". Foi conferida não a todos os empregadores rurais, nem para qualquer atividade, mas apenas aos produtores rurais pessoas físicas e para atividades de natureza temporária. São limitações de dois tipos, uma relacionada ao sujeito contratante, outra ao objeto contratado.

A limitação a produtores rurais, pessoas físicas, é compatível com a intenção, mencionada na exposição de motivos, de buscar alcançar aqueles que carecem de "estrutura administrativa mínima”. Para o legislador, produtores rurais constituídos em pessoas jurídicas possuem estrutura administrativa satisfatória, ficando excluídos da nova modalidade jurídica, voltada aos produtores com maiores dificuldades de ordem prática para o cumprimento das normas trabalhistas e previdenciárias.

O contrato deve ter por objeto atividades de natureza temporária. Incluem-se entre tais atividades as relacionadas à safra, pois a sazonalidade das atividades rurais decorrentes justamente da safra, foi expressamente citada na exposição de motivos ${ }^{334}$. Em outras palavras, as "atividades de natureza temporária" mencionadas no dispositivo podem ser inclusive aquelas cuja "duração dependa de variações estacionais da atividade agrária", expressão utilizada pelo parágrafo único do artigo 14 da Lei n. ${ }^{\circ} 5.889 / 73$, referente ao contrato de safra. Não se vislumbra motivo para que assim não seja. Nota-se que o contrato por pequeno prazo não se confunde com o contrato de safra ${ }^{335}$, mas, sob essa perspectiva, pode ser utilizado para a mesma finalidade, desde que respeitados os requisitos diferenciados impostos para a nova figura contratual.

O contrato por pequeno prazo representa mais uma exceção ao princípio da continuidade da relação de emprego, como bem observado por Gustavo Felipe Barbosa Garcia $^{336}$. Tal exceção está plenamente autorizada pelo ordenamento jurídico pátrio, pois se enquadra na hipótese da alínea "a" do $\S 2^{\circ}$ do artigo 443 da CLT $^{337}$. A determinação do

\footnotetext{
334 “Considerando-se que, na área rural, há uma predominância de trabalho sazonal, em períodos de safra, a proposta visa incluir artigo na Lei $n^{\circ} 5.889$, de 8 de junho de 1973, que estatui normas reguladoras do trabalho rural, para instituir a contratação simplificada do trabalhador temporário rural".

${ }^{335}$ Gustavo Felipe Barbosa Garcia é inequívoco ao se referir ao artigo 14-A da Lei n. ${ }^{\circ}$ 5.889/73: "Trata-se de nova modalidade de contrato por prazo determinado, específico para o âmbito rural, e que não se confunde com o contrato de safra". GARCIA, Gustavo Filipe Barbosa. Contrato de trabalho rural por pequeno prazo e precarização das relações de trabalho no campo. LTr: suplemento trabalhista, São Paulo n. 108/109, p. 509-512, 2009.

${ }^{336}$ GARCIA, Gustavo Filipe Barbosa. Contrato de trabalho rural por pequeno prazo e precarização das relações de trabalho no campo, cit., p. 509.

${ }^{337}$ Conforme Regulamento das Relações Individuais e Coletivas de Trabalho Rural, aprovado pelo Decreto n. ${ }^{\circ} 73.626 / 74$, o artigo 443 da CLT é aplicável às relações de trabalho rural.
} 
prazo se justifica pela natureza das atividades a serem prestadas, necessariamente temporária.

Conclui-se, via de consequência, que a utilização da nova modalidade contratual para atividades de natureza não temporária configura desvirtuamento e fraude, aplicandose o artigo $9^{\circ}$ da CLT $^{338}$. O ato deverá ser considerado, portanto, nulo de pleno direito, prevalecendo o contrato por prazo indeterminado, próprio para as atividades permanentes.

O parágrafo primeiro ${ }^{339}$ limitou a duração do contrato a dois meses, dentro do período de um ano, após o que o contrato se converte automaticamente em contrato por prazo indeterminado, com aplicação das normas pertinentes. Cuidou-se de evitar que a nova figura contratual pudesse substituir os contratos por prazo indeterminado, precarizando situações anteriormente estabelecidas. Não se encontra óbice para que o contrato por pequeno prazo seja prorrogado, desde que respeitado esse limite ${ }^{340}$.

A limitação confirma a intenção apresentada na exposição de motivos, cingindo a nova figura contratual às atividades de curta duração, consideradas as mais difíceis de serem formalizadas pelos pequenos produtores rurais. Como exemplo de atividades com tais características pode ser citado o plantio em pequenos espaços, com duração de semanas ou dias ${ }^{341}$, a colheita nas mesmas condições e tratos culturais não permanentes, como o combate a uma praga específica, ou a poda de determinadas plantas.

O parágrafo seguinte determinou que a inclusão do trabalhador na GFIP é suficiente para sua filiação à Previdência Social e também inscrição no regime, cabendo à Previdência Social instituir mecanismo que permita sua identificação:

$\S 2^{0}$ A filiação e a inscrição do trabalhador de que trata este artigo na Previdência Social decorrem, automaticamente, da sua inclusão pelo empregador na Guia de Recolhimento do Fundo de Garantia do Tempo de Serviço e Informações à Previdência Social - GFIP, cabendo à Previdência Social instituir mecanismo que permita a sua identificação.

\footnotetext{
${ }^{338}$ Aplicável às relações de trabalho rural, conforme Regulamento das Relações Individuais e Coletivas de Trabalho Rural, aprovado pelo Decreto n. ${ }^{\circ}$ 73.626/74.

${ }^{339}$ Art. 14-A, $\S 1^{o}:$ A contratação de trabalhador rural por pequeno prazo que, dentro do período de 1 (um) ano, superar 2 (dois) meses fica convertida em contrato de trabalho por prazo indeterminado, observandose os termos da legislação aplicável.

${ }^{340}$ GARCIA, Gustavo Filipe Barbosa. Contrato de trabalho rural por pequeno prazo e precarização das relações de trabalho no campo. $L T r$, cit., p. 510-511.

${ }^{341}$ Id. Curso de direito do trabalho, cit., p. 211.
} 
A norma unificou dois momentos em um único ato. Trata-se de aparente simplificação para o empregador, pois, com o único ato de incluir o trabalhador na GFIP, promove-se automaticamente tanto sua filiação à Previdência Social quanto sua inscrição.

A diferença entre filiação e inscrição é esclarecida pelo Regulamento da Previdência Social, aprovado pelo Decreto n. ${ }^{\circ}$ 3.048/99. Filiação, segundo o artigo 20 do Regulamento, é o "vínculo que se estabelece entre pessoas que contribuem para a previdência social e esta, do qual decorrem direitos e obrigações”. Já inscrição, conforme artigo 18, caput é o "ato pelo qual o segurado é cadastrado no Regime Geral de Previdência Social."

A regra é clara, é a partir da filiação, não da inscrição, que nascem direitos e obrigações. A inscrição é, portanto, apenas formalização de uma situação de fato, de um vínculo existente entre a pessoa e a Previdência Social.Sergio Pinto Martins ${ }^{342}$ é inequívoco:

\footnotetext{
"Filiação não se confunde com inscrição. (...) O simples ingresso em atividade abrangida pelo Regime Geral de Previdência Social determina a filiação automática a esse regime. (...) A inscrição é o ato do registro do segurado no âmbito interno do INSS."
}

Nesse contexto, para todos os segurados obrigatórios da Previdência Social, com exceção do trabalhador contratado segundo a regra em estudo, a filiação e a inscrição acontecem em momentos diversos. A filiação se dá de forma automática, a partir do exercício de atividade remunerada, conforme $\S 1^{\circ}$ do artigo 20 do Regulamento da Previdência Social. A inscrição, por sua vez, é o ato de cadastrar o segurado, e depende da formalização do seu contrato de trabalho, segundo o inciso I do artigo 18 do referido Regulamento.

Para o trabalhador contratado por pequeno prazo, a situação é diferente. Tanto a filiação quanto a inscrição decorrem de maneira automática de um único ato, qual seja, sua inclusão na GFIP, pelo empregador. Aqui está a aparente redução da burocracia, na prática inexistente, pois é mantido para o empregador o dever de incluir o nome do trabalhador em GFIP, para promover a inscrição. A filiação, que para os outros empregados se dá a partir do exercício de atividade remunerada, no caso em estudo é transferida para o ato burocrático de inclusão do trabalhador em GFIP. A única redução de burocracia existente é

\footnotetext{
${ }^{342}$ MARTINS, Sérgio Pinto. Direito da seguridade social. 19. ed. São Paulo. Atlas 2003. p. 139.
} 
a dispensa da anotação do contrato de trabalho em Carteira de Trabalho e Previdência Social (CTPS) e o registro em livro ou ficha. Em verdade, trata-se não de redução, mas de substituição de tarefa burocrática, como será analisado mais adiante.

Entretanto, há que se observar a questão também por outro ângulo. Lembre-se que o Regulamento da Previdência Social é claro ao afirmar, no artigo 20, caput, que é da filiação que decorrem direitos e obrigações. Enquanto todos os demais segurados obrigatórios da previdência social adquirem a filiação a partir de uma situação de fato (o exercício de atividade remunerada), o trabalhador contratado pelas novas regras somente vai adquirir a condição de filiado à previdência social após um ato de escritório, a sua inclusão em GFIP pelo empregador. Ou seja, os demais segurados obrigatórios da previdência social já se habilitam a possuir direitos previdenciários pelo simples fato de terem exercido atividade remunerada, ainda que o empregador não os inclua em GFIP, ou deixe de recolher as contribuições devidas, ou deixe até mesmo de formalizar o contrato de trabalho. No entanto, o trabalhador rural por pequeno prazo somente será considerado filiado a partir da sua inclusão em GFIP pelo empregador, não bastando o exercício de atividade remunerada.

Conclui-se que a nova regra aparenta reduzir a burocracia para o produtor rural pessoa física, no entanto, amplia explicitamente o peso da burocracia sobre o trabalhador rural, que passa a depender de um ato burocrático para se filiar a previdência, enquanto os demais segurados obrigatórios não dependem de burocracia alguma para tanto. Evidentemente, aumenta-se também a dependência do trabalhador em relação ao seu patrão, pois sequer filiado à previdência social o trabalhador será, caso o empregador não o inclua em GFIP.

A disposição normativa deixou o trabalhador rural fragilizado em relação ao seu empregador e em relação à própria Previdência Social, pois ainda que o trabalhador comprove o exercício de atividade remunerada, a não inclusão em GFIP é suficiente para que o INSS lhe negue os direitos previdenciários, já que não ficou caracterizada sequer a sua filiação ao regime. Levando em consideração que o trabalhador não possui a menor possibilidade de interferir na iniciativa do empregador para a inclusão do seu nome em GFIP, parece inevitável concluir que a nova regra fragilizou a situação dos trabalhadores rurais a que se destina.

Trata-se de grave contradição, pois conforme a exposição de motivos da medida provisória, um dos principais problemas a serem enfrentados seria justamente a exclusão 
do trabalhador rural do regime previdenciário, mas, para a filiação deste, criou-se uma barreira burocrática, antes inexistente. Se a inscrição ficou mais simples, a filiação, que é justamente o ato a partir do qual decorrem os direitos, ficou mais difícil, mais burocrática.

Para se evitar tal contradição seria imprescindível que a filiação do trabalhador ao regime previdenciário continuasse sendo automática pelo simples exercício de atividade remunerada, prescindindo de qualquer ato burocrático. Esse conceito é de vital importância para a defesa dos interesses e direitos dos trabalhadores perante a Previdência Social, pois independentemente da conduta lícita ou ilícita do empregador, fica garantido ao trabalhador o acesso aos benefícios previdenciários. A nova figura, ao concentrar a filiação e a inscrição em um ato burocrático, de iniciativa única do empregador, tolheu essa vantagem do trabalhador, causou séria fragilização da sua situação.

A redução da burocracia para o empregador não precisaria ser feita da maneira que foi, é dizer, seria possível manter a filiação a partir do exercício da atividade remunerada, e mesmo assim reduzir a burocracia, pois esta se encontra no ato da inscrição do trabalhador na Previdência Social, não da filiação. Bastaria prever que a inscrição do trabalhador na Previdência Social (somente a inscrição, não a filiação) decorreria automaticamente da sua inclusão em GFIP, sem a necessidade de formalização do contrato de trabalho em Carteira de Trabalho e Previdência Social e registro em livro ou ficha. Em termos práticos, bastaria retirar do parágrafo $2^{\circ}$ do artigo 14-A, a palavra "filiação".

É imperioso reconhecer que a nova norma ofendeu o princípio da igualdade, positivado no caput do artigo $5^{\circ}$ da Constituição da República. Tal princípio se destina, como bem observado por Sérgio Pinto Martins ${ }^{343}$, ao legislador ordinário, que não deve dispensar tratamento diferenciado para situações iguais. No presente caso, foi exatamente isso que aconteceu, o legislador tratou de maneira diferenciada e prejudicial, no âmbito da seguridade social, o trabalhador contratado por pequeno prazo, apesar de sua situação ser igual à dos demais segurados obrigatórios da previdência social, especialmente os trabalhadores contratados por prazo determinado. Há inegável inconstitucionalidade material, por afronta explícita ao artigo $5^{\circ}$, caput, da Constituição da República.

Na parte final do parágrafo a lei determina à Previdência Social o encargo de instituir mecanismo que permita a identificação do trabalhador rural contratado por

\footnotetext{
${ }^{343}$ Nas palavras do autor: "violará o princípio constitucional da igualdade se o legislador ordinário determinar tratamentos desiguais para duas situações iguais, sob a ótica da seguridade social" MARTINS, Sérgio Pinto. Direito da seguridade social, cit., p. 69.
} 
pequeno prazo. Faz-se necessária tal identificação, pois como será visto adiante, a alíquota da contribuição previdenciária será sempre de $8 \%$, afastando-se a progressão constante da tabela do artigo 20 da Lei n. ${ }^{\circ}$ 8.212/91. Nesse contexto, caberá ao empregador manter-se alerta no momento de preencher a GFIP, atendendo ao mecanismo que for instituído pela Previdência Social para a identificação específica do tipo de contrato.

Observa-se outra contradição na norma. Não é possível enquadrar a tarefa de apresentar GFIP com mais esse detalhe como simplificação ou redução da burocracia. Não é algo desejável para facilitar os procedimentos a quem não possui sequer "estrutura administrativa mínima", como afirmara a exposição de motivos. A norma, em verdade, criou não uma facilidade, mas um detalhe a mais a ser observado, uma dificuldade.

O parágrafo terceiro previsto pela medida provisória foi profundamente alterado com a edição da Lei n.11.718/08. A redação dada pela medida provisória era a seguinte:

$\S 3^{\circ} \mathrm{O}$ contrato de trabalhador rural por pequeno prazo não necessita ser anotado na Carteira de Trabalho e Previdência Social ou em Livro ou Ficha de Registro de Empregados, mas, se não houver outro registro documental, é obrigatória a existência de contrato escrito com o fim específico de comprovação para a fiscalização trabalhista da situação do trabalhador.

$\mathrm{Na}$ antiga redação se percebe a preocupação primeira em dispensar o empregador de anotar o contrato de trabalho nos documentos próprios, afastando a aplicação dos artigos 29 e 41 da CLT $^{344}$. A regra seria a concretização do objetivo de se poupar o empregador do dever de formalizar o contrato de trabalho.

Entretanto, esse objetivo era perturbado pela parte final do próprio parágrafo $3^{\circ}$, ao determinar a necessidade de haver algum registro documental do contrato. Não havendo qualquer registro documental, a norma impunha ao empregador a obrigação de formalizar o contrato por meio de documento escrito, para fins exclusivos de comprovação perante a fiscalização trabalhista.

Com a conversão da medida provisória em lei, o dispositivo foi alterado, passando a assumir a seguinte redação:

$\S 3^{\mathrm{o}} \mathrm{O}$ contrato de trabalho por pequeno prazo deverá ser formalizado mediante a inclusão do trabalhador na GFIP, na forma do disposto no $\S 2^{\circ}$ deste artigo, e:

\footnotetext{
${ }^{344}$ Tais artigos seriam, em princípio, aplicáveis, conforme artigo $1^{\circ}$ da Lei n. ${ }^{\circ} 5.889 / 73$, c/c artigo $4^{\circ}$ do Regulamento da mesma lei, aprovado pelo Decreto n. ${ }^{\circ} 73.626 / 74$.
} 
I - mediante a anotação na Carteira de Trabalho e Previdência Social e em Livro ou Ficha de Registro de Empregados; ou

II - mediante contrato escrito, em 2 (duas) vias, uma para cada parte, onde conste, no mínimo:

a) expressa autorização em acordo coletivo ou convenção coletiva;

b) identificação do produtor rural e do imóvel rural onde o trabalho será realizado e indicação da respectiva matrícula;

c) identificação do trabalhador, com indicação do respectivo Número de Inscrição do Trabalhador - NIT.

A mudança trocou o núcleo normativo. Antes a norma, em primeiro lugar, dispensava o empregador de formalizar a relação de trabalho, trazendo ao seu final a necessidade de apresentar alguma comprovação material para a fiscalização do trabalho. Após a alteração, a preocupação central da norma deixou de ser a liberação do empregador das obrigações formais, ou a sua conduta perante a fiscalização do trabalho. Passou a ser a necessidade de formalizar a relação de trabalho. De maneira didática, a nova redação deixa clara a necessidade de inclusão do nome do trabalhador em GFIP e, além disso, a existência de duas alternativas ao empregador, quais sejam, o registro do trabalhador nos moldes dos artigos 29 e 41 da CLT, ou o contrato escrito em duas vias. Para essa segunda opção houve então o estabelecimento de um conteúdo mínimo, disposto em três alíneas.

A alínea "a" exigiu expressa autorização por negociação coletiva, para a ausência de registro em CTPS e livro ou ficha, trazendo ao contexto a participação do sindicato profissional, que até então não fora mencionado, quer na medida provisória, quer na exposição de motivos. Não fazia parte da origem do novo instituto a ideia da participação sindical. A alteração promovida pela lei parece, em um primeiro momento, vir ao encontro dos interesses dos trabalhadores e do movimento sindical, pois além de deixar ao sindicato a prerrogativa de autorizar ou não a ausência de registro, permite ao sindicato conhecer de antemão as novas relações que irão se apresentar em sua base territorial, facilitando-lhe a defesa dos interesses dos seus representados. Entende-se como salutar a valorização da autonomia da vontade coletiva, o prestígio à participação dos sindicatos ${ }^{345}$. Entretanto, há

\footnotetext{
345 “Como se nota, com a Lei $n^{\circ}{ }^{11}$ 1.718/2008, houve certa evolução quanto ao tema, pois para que se admita a ausência de anotação do contrato do trabalhador rural por pequeno prazo na Carteira de Trabalho e Previdência Social (CTPS) e em Livro ou Ficha de Registro de Empregados, passou-se a exigir que o contrato escrito (em duas vias, uma para cada parte) indique a 'expressa autorização em acordo coletivo ou convenção coletiva', (...). Assim sendo, apenas se houver autorização nesse sentido, em instrumento normativo decorrente de negociação coletiva de trabalho (art. $7^{\circ}$, inciso XXVI da CF/1988), é que a Lei autoriza a contratação na forma mencionada. Tendo em vista essa exigência, deve-se destacar o papel do
} 
ressalvas a serem observadas. A autorização negocial requerida pela legislação não se faz necessária para a utilização da nova figura, mas tão somente para que o empregador seja dispensado de efetuar o registro. Se o empregador, ao utilizar a nova figura contratual, optar pelo inciso I do $\S 3^{\circ}$ (registro em CTPS e Livro ou Ficha), não será necessária sequer a comunicação ao sindicato.

Ou seja, apesar de a legislação prestigiar a participação sindical, o faz de maneira parcial, incompleta, chamando o sindicato somente para a parte final do processo, e ainda assim, somente se o empregador optar por uma das duas alternativas que lhe são possíveis. Trata-se de participação sindical não efetiva, que não interfere na decisão de se utilizar ou não a nova figura contratual, é uma participação secundária e limitada. Observa-se, ademais, que norma fala apenas em autorização para o não registro dos empregados, que pode ser, assim, genérica, entabulada em uma convenção coletiva com ampla abrangência territorial. Não há qualquer necessidade de cada empregador informar, antes, durante, ou depois da contratação, a real utilização da mão de obra não registrada, o número de pessoas contratadas, por quanto tempo, ou para quais atividades. Tais informações seriam um valioso banco de dados para orientar a defesa dos interesses da categoria, a médio e longo prazos, facilitando a elaboração de estatísticas e pesquisas sobre as relações de trabalho rural, e até mesmo a busca por indícios de fraude. Aí sim, a participação sindical poderia assumir importante papel, auxiliando inclusive a atuação da Auditoria-Fiscal do Trabalho e do Ministério Público do Trabalho. Entretanto, não foi essa a intenção do legislador.

Por outro lado, há nova contradição na norma, que teve em sua origem a intenção de reduzir a burocracia, facilitar a contratação para aqueles que não possuem estrutura administrativa mínima. Ao dispensar o empregador de providenciar os registros previstos nos artigos 29 e 41 da CLT, a norma lhe impõe outro encargo em substituição, obrigandolhe a obter prévia autorização sindical. No caso de tal autorização não estar contemplada em convenção coletiva, o empregador deverá entabular sozinho negociações com o sindicato dos trabalhadores para providenciar um acordo coletivo que lhe autorize a utilizar, no lugar dos registros, um contrato escrito. Considerando ser a intenção da norma atingir os empregadores rurais pessoas físicas, com precárias estruturas administrativas, há que se concordar que o registro dos trabalhadores, nos termos dos artigos 29 e 41 da CLT, seria muito mais prático e fácil do que todo o processo de negociação com o sindicato 
profissional. Até porque a norma deu total liberdade ao sindicato para autorizar ou não a conduta. Não há predeterminação de critério algum, o sindicato poderá alegar qualquer motivo para deixar de autorizar, ou mesmo deixar de autorizar sem apresentar motivo algum. O reflexo disso é evidente, a opção pela ausência de registro deixou de ser um direito do empregador rural, passou a ser uma concessão do sindicato.

Conclui-se que a legislação, além de prestigiar de maneira deficiente os interesses do movimento sindical, parece afastar o empregador da opção do não registro, que pode se tornar mais demorada, complexa e trabalhosa que a anotação do contrato em CTPS e o registro em livro ou ficha próprios. Um dos principais objetivos mencionados na exposição de motivos era justamente permitir a contratação de trabalhadores sem anotação em CTPS e registro em livro ou ficha. Entretanto, com a nova redação do $\S 3^{\circ}$, essa alternativa saiu da esfera de decisão exclusiva do empregador, passou a ser uma decisão do sindicato profissional.

As alíneas "b" e "c" apresentam mais exigências impostas ao empregador que optar por não registrar seus trabalhadores, obrigado a introduzir informações cadastrais no contrato escrito, inclusive o imóvel em que o trabalho será realizado, com respectiva matrícula. Se o produtor rural possuir mais de um imóvel, deverá fazer constar no contrato todos os imóveis em que os trabalhadores irão exercer suas atividades. Não seria razoável interpretar que a legislação, ao utilizar a expressão "o imóvel”, no singular, pretendeu restringir o trabalho a um único local. A indicação do imóvel onde o trabalho poderá ser realizado contribui para evitar que os trabalhadores sejam utilizados como mão de obra terceirizada em outros imóveis. Essa foi a intenção do legislador. Nesse contexto, não havendo terceirização irregular, e desde que respeitados os demais direitos trabalhistas, não haveria razão para se restringir a possibilidade de trabalho a um único imóvel.

A facultatividade da anotação na CTPS e do registro em livro ou ficha constitui o aspecto mais polêmico da norma, recebendo pesadas críticas na doutrina ${ }^{346}$.

O parágrafo seguinte ${ }^{347}$ reforçou a (já mencionada no caput) restrição subjetiva do contrato, limitado a produtores rurais pessoas físicas. A norma então esclarece que o produtor pode ser proprietário ou não, mas deve explorar diretamente atividade agroeconômica. Trata-se de parágrafo inserido pela Lei n. ${ }^{\circ}$ 11.718/08, pois tal disposição

\footnotetext{
${ }^{346}$ Ver infra, p. 155 e ss.

${ }^{347}$ Art. 14-A, $\$ 4^{\circ}$ A contratação de trabalhador rural por pequeno prazo só poderá ser realizada por produtor rural pessoa física, proprietário ou não, que explore diretamente atividade agroeconômica.
} 
não havia na redação original da medida provisória. A figura serve, portanto, não apenas aos proprietários rurais, mas também aos arrendatários e demais produtores.

O parágrafo $5^{\circ}$ trouxe importante característica da nova figura contratual, a alíquota fixa de $8 \%$ sobre o salário de contribuição, para a contribuição previdenciária do trabalhador:

$\S 5^{\circ}$ A contribuição do segurado trabalhador rural contratado para prestar serviço na forma deste artigo é de $8 \%$ (oito por cento) sobre o respectivo salário de contribuição definido no inciso I do caput do art. 28 da Lei ${ }^{\circ}$ 8.212, de 24 de julho de 1991.

Afastou-se, assim, a progressão de alíquotas da tabela do artigo 20 da Lei n. ${ }^{\circ}$ 8.212/91, mantendo-se o cálculo pela alíquota mínima. Trata-se da única disposição da nova norma que se referiu diretamente aos custos do contrato. $\mathrm{O}$ impacto se dá diretamente sobre o valor recebido pelo trabalhador, ou seja, não reduz diretamente quanto o empregador gasta, mas aumenta o valor líquido recebido pelo trabalhador, já que o desconto no seu salário será sempre de apenas 8\%. Indiretamente poderá haver ganhos para o produtor, que será capaz de aumentar a remuneração dos trabalhadores sem majorar a alíquota de desconto, atraindo mais facilmente mão de obra. Entretanto, trata-se de ganho apenas indireto, podendo-se afirmar que a manutenção da alíquota no percentual mínimo não parece reduzir significativamente os custos do contrato para o pequeno produtor rural.

A seguir, a lei trouxe a determinação de que a não inclusão do trabalhador em GFIP pressupõe a inexistência de contratação na forma do artigo, permitindo-se comprovar relação jurídica diversa:

$\S 6^{0}$ A não inclusão do trabalhador na GFIP pressupõe a inexistência de contratação na forma deste artigo, sem prejuízo de comprovação, por qualquer meio admitido em direito, da existência de relação jurídica diversa.

A redação não deixou explícito se a presunção é relativa ou absoluta. Deve-se reconhecer a imposição de consequência severa para o ato de não incluir o trabalhador em GFIP. Apesar da falta de clareza do legislador, trata-se de presunção absoluta, ou seja, a inclusão do nome do trabalhador na guia previdenciária constitui verdadeiro requisito para a utilização da nova figura contratual, pressuposto de sua existência válida. Via de 
consequência, a não inclusão do trabalhador em GFIP equivale, de maneira irremediável, à não adoção da nova forma contratual.

Essa interpretação se coaduna com os objetivos apresentados na exposição de motivos da Medida Provisória, relativos à inclusão do trabalhador rural no sistema previdenciário. O contrato por pequeno prazo foi criado com objetivo de garantir ao trabalhador rural a efetivação do direito aos benefícios previdenciários, através da pretendida facilitação de sua filiação e inscrição. Esta se revela, inegavelmente, como parte central do novo tipo contratual, seu âmago. A falta de inscrição faz do contrato imprestável ao seu principal objetivo, torna inútil sua utilização. Em outras palavras, de nada adiantaria fazer uso da figura contratual sem promover a inclusão do trabalhador em GFIP. É nesse contexto que a interpretação da norma deve se dar. Assim, a falta de inclusão do trabalhador em GFIP não é mera falha escusável, algo sem o qual o contrato poderia subsistir. Antes, a inserção do trabalhador em GFIP deve ser entendida como condição sine qua non para a existência válida do contrato. A omissão do empregador, portanto, faz com que se conclua, inescapavelmente, pela inexistência da contratação na forma estipulada, subsistindo relação jurídica diversa.

Ainda que ambos, empregador e trabalhador, confirmem a vontade previamente declarada em celebrar o contrato por pequeno prazo, ainda que a falta de inclusão do trabalhador em GFIP não tenha sido causada com intenção de fraude, mas por mera falha burocrática, permanece a necessidade de se reconhecer a nulidade do contrato, pois sua essência lhe foi negada. Aplica-se o princípio da irrenunciabilidade dos direitos trabalhistas, não se podendo dar crédito à renúncia do trabalhador ao principal direito visado pela nova figura contratual, a sua inclusão no sistema previdenciário. Principalmente por ser a inclusão previdenciária questão de ordem pública ${ }^{348}$.

Essa ideia é reforçada pela parte final do parágrafo, que permite a comprovação de relação jurídica diversa. Caso se tratasse de presunção relativa, seria possível comprovar, por diferentes meios, a existência da própria contratação por pequeno prazo, derrubando-se a presunção. Mas a lei permitiu a comprovação apenas de relação jurídica diversa, restando inequívoco o caráter absoluto da presunção.

\footnotetext{
348“ $O$ princípio da irrenunciabilidade significa não se admitir, em tese, que o empregado renuncie, ou seja, abra mão dos seus direitos assegurados pelo sistema jurídico trabalhista, cujas normas são, em sua grande maioria, de ordem pública.”. GARCIA, Gustavo Filipe Barbosa. Curso de direito do trabalho, cit., p. 104.
} 
A norma determina, portanto, na falta de inclusão do trabalhador em GFIP, presunção absoluta de inexistência da contratação na forma estipulada. Não obstante, permanece um vínculo entre o produtor rural e o trabalhador. Há que se esclarecer, a partir disso, qual a natureza desse vínculo, qual relação jurídica subsiste.

Os elementos presentes nessa relação remanescente são os característicos do vínculo empregatício. O trabalho prestado é inequivocamente por conta alheia, os riscos econômicos da atividade rural são do produtor, havendo clara alteridade, com subordinação, onerosidade, pessoalidade e não eventualidade. Este último critério se faz presente, apesar de as atividades serem de natureza temporária, pois o critério da não eventualidade não se restringe ao caráter temporal. Desse modo, embora temporárias as atividades, o trabalho não se classifica como eventual. Gustavo Filipe Barbosa Garcia ${ }^{349}$ afirma:

"Trabalho não eventual, num primeiro enfoque, é aquele habitual,
contínuo. Pode-se dizer, entretanto, que a não eventualidade significa a
prestação de serviços ligados às atividades normais do empregador, ou
seja, realizando serviços permanentemente necessários à atividade do
empregador ou ao seu empreendimento".

$\mathrm{Na}$ figura em estudo, o trabalhador, de fato, não está inserido continuamente na “organização para a qual o serviço é prestado". Isso, no entanto, não é suficiente para lhe retirar a não eventualidade e, com isso, a condição de empregado. Todos os contratos de emprego por prazo determinado apresentam a mesma circunstância e, ainda assim, conservam a não eventualidade como marca empregatícia. Ocorre que o trabalhador rural por pequeno prazo presta serviços inerentes aos fins principais da atividade econômica do empregador, ou seja, realiza tarefas rurais, serviços ligados às atividades normais do empregador. Contribui para a produção cotidiana do estabelecimento, ainda que de maneira indireta.

Octavio Bueno Magano ${ }^{350}$, ao tratar do empregado rural e do contrato de safra, é inequívoco ao afirmar que o trabalho nas necessidades cíclicas, ainda que temporárias, do empregador rural, não deve ser considerado eventual. A eventualidade, para ser caracterizada, necessita não apenas do curto espaço de tempo, mas também do

\footnotetext{
${ }^{349}$ Id. Ibid., p. 150. Amauri Mascaro Nascimento também aborda a questão:

"No trabalho eventual não há uma inserção continuada do prestador na organização para a qual o serviço é prestado, nem a inerência desse trabalho nos fins principais da atividade econômica da empresa, dada a singularidade do opus ou resultado, em cujo cumprimento se exaure o contrato." NASCIMENTO, Amauri Mascaro. Curso de direito do trabalho. 26. ed., cit., p. 575.

${ }^{350}$ MAGANO, Octávio Bueno. Manual de direito do trabalho. 2. ed., cit., p. 108.
} 
distanciamento das atividades normais e permanentes da empresa, fornecendo o autor exemplos esclarecedores de trabalhos eventuais:

"Requisito também necessário para a configuração do empregado rural é o de não serem eventuais os serviços por ele prestados. O conceito de eventualidade está ligado a trabalho de curta duração, que, ademais, não responda a necessidades normais e permanentes da empresa. Nessa categoria podem ser inseridos os trabalhos de drenagem de um pântano; de extinção de um incêndio; de construção de uma casa; de reparo de um estábulo; de instalação de uma rede elétrica, etc. Como eventuais não podem ser considerados os trabalhas de safra, caracterizados pela lei como de duração dependente de variações estacionais da atividade agrária. (...). E não são eventuais por corresponderem a necessidades cíclicas do empreendimento agroeconômico."

É necessário reconhecer, portanto, a presença da não eventualidade e, assim, a natureza empregatícia da relação remanescente. Resta saber se essa relação, emersa em função da não inclusão do trabalhador em GFIP, é por prazo determinado ou indeterminado.

A norma não indica expressamente a solução dessa dúvida, deixando abertas algumas possibilidades. O parágrafo $1^{\circ}$ do artigo 14-A transforma o contrato em contrato por prazo indeterminado, caso seja ultrapassado o prazo de dois meses no ano. É possível defender a aplicação analógica dessa regra, prestigiando o princípio da continuidade da relação de emprego. A falta de inclusão do nome do trabalhador em GFIP transformaria o contrato, então, em contrato por prazo indeterminado, gerando um grande ônus ao empregador, especialmente ao término da relação contratual. Sem maiores explicações, Ulisses Octávio Elias dos Santos ${ }^{351}$ entende dessa maneira, afirmando que o contrato, na falta de inclusão do trabalhador em GFIP, se converte automaticamente em contrato por prazo indeterminado.

Entretanto, depõe contra essa opção o fato de o trabalhador ter sido contratado para atividades de natureza temporária. A CLT cita expressamente a natureza temporária das atividades objeto do contrato como motivo suficiente para excepcionar o referido princípio da continuidade, autorizando a predeterminação do prazo do contrato. Trata-se do artigo

\footnotetext{
${ }^{351}$ SANTOS, Ulisses Otávio Elias dos. Considerações sobre o contrato de pequeno prazo no trabalho rural. Revista Bonijuris, Curitiba, v. 20, n. 538, p. 22, set. 2008.
} 
443, § 2 $2^{\circ}$, alínea "a"da CLT ${ }^{352}$ (aplicável às relações de trabalho rural, conforme art. $4^{\circ}$ do Decreto.$^{\circ}$ 73.626/74).

É defensável, sob esse ângulo, entender presente o vínculo empregatício por prazo determinado, nos moldes da norma supra. Considerando que as atividades de natureza temporária podem perfeitamente estar ligadas aos serviços próprios da safra, é possível entender presente o contrato de safra previsto no artigo 14, parágrafo único, da Lei n. ${ }^{\circ}$ $5.889 / 73$.

O intérprete, ao se debruçar sobre tais opções, ou outras que lhe parecer plausíveis, deve sempre ter em mente um dos mais relevantes princípios do Direito do Trabalho, o da primazia da realidade. Sua aplicação, aliada à análise cuidadosa do caso concreto, deve determinar qual caminho seguir. Caso a verificação das circunstâncias fáticas revele a prática de atividades de natureza não temporária, mas permanente, inevitável será a conclusão pela existência de vínculo empregatício por prazo indeterminado, mascarado pela utilização fraudulenta do contrato por pequeno prazo. Por outro lado, se a omissão do nome do trabalhador em GFIP se revelar mera falha procedimental, permanecendo na prática a realização de atividades de natureza temporária, o mais adequado seria considerar existente contrato de emprego por prazo determinado, podendo ser inclusive o contrato de safra, se as atividades tiverem sua duração "dependente de variações estacionais da atividade agrária" ${ }^{353}$.

Desse modo, andou bem o legislador quando se limitou a definir a presunção absoluta da inexistência da contratação na forma estabelecida, deixando ao intérprete a tarefa de descobrir, na ausência do contrato por pequeno prazo, a relação subjacente. A omissão legal sobre qual relação jurídica deve emergir a partir da inexistência do contrato por pequeno prazo não deve ser considerada como indesejável insegurança jurídica. Ao contrário, revela-se como excelente oportunidade de aproximação do direito à realidade, aumentando a eficácia jurídica e a probabilidade de a verdadeira relação jurídica existente ser reconhecida, ainda que mascarada pelo contrato por pequeno prazo.

\footnotetext{
${ }^{352}$ Art. 443 - O contrato individual de trabalho poderá ser acordado tácita ou expressamente, verbalmente ou por escrito e por prazo determinado ou indeterminado.

$\S 1^{o}$ - Considera-se como de prazo determinado o contrato de trabalho cuja vigência dependa de termo prefixado ou da execução de serviços especificados ou ainda da realização de certo acontecimento suscetível de previsão aproximada.

$\S 2^{o}$ - O contrato por prazo determinado só será válido em se tratando:

a) de serviço cuja natureza ou transitoriedade justifique a predeterminação do prazo;

${ }^{353}$ Expressão utilizada pelo parágrafo único do art. 14 da Lei n. ${ }^{\circ} 5.889 / 73$, relativo ao contrato de safra.
} 
A margem deixada ao intérprete pelo legislador valoriza o princípio da primazia da realidade, tão caro ao Direito Laboral. Permite que o produtor rural bem intencionado, que cometeu o erro sem dolo, mantenha a característica de prazo determinado da relação, não arcando com o ônus exagerado da relação empregatícia por prazo indeterminado. Por outro lado, garante a possibilidade de o produtor rural mal intencionado, que utilizou o contrato para tentar mascarar uma verdadeira relação empregatícia por prazo indeterminado, arcar com os custos próprios do contrato que tentou esconder.

O parágrafo $7^{\circ}$ manteve para $\mathrm{o}$ produtor rural a obrigação de providenciar $\mathrm{o}$ recolhimento das contribuições previdenciárias, nos termos da legislação vigente, criando para a Previdência Social e Receita Federal do Brasil o dever de instituir mecanismos que facilitem o acesso do trabalhador e do seu sindicato às informações sobre as contribuições recolhidas:

$\S 7^{0}$ Compete ao empregador fazer o recolhimento das contribuições previdenciárias nos termos da legislação vigente, cabendo à Previdência Social e à Receita Federal do Brasil instituir mecanismos que facilitem o acesso do trabalhador e da entidade sindical que o representa às informações sobre as contribuições recolhidas.

A norma não reduziu a burocracia para o empregador, mas criou o dever para a Administração Pública de providenciar tais mecanismos. A intenção do legislador de aproximar o trabalhador rural do sistema previdenciário é clara, procurando criar um meio de auxiliá-lo no acompanhamento dos recolhimentos das contribuições previdenciárias. Embora seja fruto de boa intenção, a previsão legislativa corre o risco de não concretizar seus objetivos.

É notória a distância que infelizmente existe, dede há muito, entre a população rural brasileira e uma razoável estrutura educacional. Qualquer "mecanismo" que seja instituído pela Previdência Social e Receita Federal do Brasil para "facilitar o acesso do trabalhador às informações sobre as contribuições recolhidas" não será capaz de superar obstáculos como o analfabetismo e o desconhecimento sobre os próprios direitos. Soma-se a isso a miséria, que fragiliza ainda mais as condições de vida de grande parte dos trabalhadores do campo $^{354}$. A fragilidade social e econômica e a ignorância que notoriamente permeiam a

\footnotetext{
${ }^{354}$ Nesse contexto, muitos trabalhadores sabem apenas desenhar o próprio nome, e podem ser constrangidos a fazê-lo em qualquer documento que o empregador lhes apresente, sem a mínima condição de ler e compreender o que estão "assinando". Em agosto de 2007 Procuradores do Ministério Público do Trabalho da $15^{\mathrm{a}}$ Região, atuando junto ao cultivo de cana de açúcar, encontraram uma série de documentos em branco assinados por trabalhadores rurais, no interior de São Paulo. O chamado "kit fraude" continha pedidos de demissão, recibos de equipamento de proteção individual, Termo de Rescisão do Contrato de Trabalho, entre outros. Matéria veiculada amplamente na mídia local à época, MENDONÇA, Maria Luisa.
} 
vida de grande parte dos trabalhadores rurais brasileiros é, infelizmente, o campo infértil onde o legislador pretendeu jogar a semente da facilitação do acesso às informações sobre os recolhimentos previdenciários.

Colocar o trabalhador como observador das contribuições previdenciárias recolhidas é louvável, mas improdutivo nas condições sociais atuais. A criação de mecanismos para facilitar o acesso dos trabalhadores rurais às informações é inútil se não há condições para que ele minimamente entenda tais informações. É preciso que o Estado Brasileiro garanta, antes do acesso às informações, um sistema educacional de qualidade, acessível à população rural. Assim, quando o trabalhador for considerado alfabetizado, não será somente por saber desenhar o próprio nome na ficha de registro, no contrato de trabalho, ou em qualquer papel em branco que inescrupulosamente lhe apresentem, mas porque sabe ler e, principalmente, consegue entender o que lê. Aí sim, o mecanismo a ser criado para facilitar o seu acesso às informações sobre as contribuições recolhidas será verdadeiramente útil.

Mas, ainda assim, o mecanismo não será capaz de atingir seus objetivos sozinho. Além de garantir o acesso à informação e basicamente o entendimento dessa informação, é preciso garantir a possibilidade de agir a partir dessas informações. Ou seja, a atuação do trabalhador na defesa dos próprios direitos deve ser também facilitada. A melhoria da estrutura sindical é fundamental nesse contexto, bem como do acesso do trabalhador rural aos órgãos que fisscalizam o recolhimento das contribuições previdenciárias.

Em suma, a mera declaração pelo legislador de que caberá à Previdência Social e à Receita Federal do Brasil a criação de mecanismos de facilitação do acesso à informação é algo muito aquém do necessário para que o trabalhador rural possa, de fato, acompanhar os recolhimentos das contribuições sociais pertinentes. É um passo demasiado pequeno para a longa trilha que precisa ser percorrida.

No parágrafo seguinte a lei garantiu ao trabalhador por pequeno prazo remuneração equivalente à do trabalhador rural permanente e, além disso, os demais direitos de natureza trabalhista:

$\S 8^{0}$ São assegurados ao trabalhador rural contratado por pequeno prazo, além de remuneração equivalente à do trabalhador rural permanente, os demais direitos de natureza trabalhista.

Morte e violação de direitos nas usinas de etanol em São Paulo. ALAI, América Latina en Movimiento, 21 set. 2007. Disponível em: <http://alainet.org/active/19784\&lang=es>. 
A norma garante aos trabalhadores por pequeno prazo equivalência remuneratória, buscando observar o princípio da isonomia. Nota-se que a norma se referiu ao "trabalhador rural permanente", deixando de utilizar o termo "empregado rural". Deve-se levar em conta que os direitos assegurados pela Lei n. ${ }^{\circ}$ 5.889/73 são aplicáveis aos empregados rurais e também aos trabalhadores rurais não empregados, conforme artigo 17 da própria lei ${ }^{355}$. Ao utilizar a expressão "trabalhador rural permanente" o legislador não inovou. Não há uma figura jurídica própria, um tipo específico de trabalhador chamado "trabalhador rural permanente", ao lado das outras figuras jurídicas existentes, como empregado, trabalhador avulso, trabalhador eventual. Não se pode dizer que a norma criou um tipo novo de contrato de trabalho. Ao contrário, a norma busca simplesmente equiparar a remuneração do trabalhador contratado por pequeno prazo, à do trabalhador rural permanente.

A atividade de equiparar exige a preexistência do objeto modelo. O lógico e possível é equiparar algo a um objeto já existente, para que o novo assuma os mesmos contornos daquilo que lhe era anterior. Não faz sentido, portanto, querer afirmar que a expressão "trabalhador rural permanente" se refira a uma nova categoria de trabalhadores rurais, criada com a Lei n. ${ }^{\circ} 11.718 / 08$.

Partindo-se dessa conclusão, resta saber se a norma se referiu aos empregados rurais definidos no artigo $2^{\circ}$ da Lei n. ${ }^{\circ} 5.889 / 73$, ou aos demais trabalhadores rurais mencionados no artigo 17 da mesma lei. A noção da permanência está intimamente ligada à caracterização do vínculo empregatício. Conforme visto acima, o critério da não eventualidade contém a ideia da inserção das tarefas do trabalhador nas atividades permanentemente desenvolvidas pelo trabalhador. Nesse diapasão, o mais lógico é entender a expressão "trabalhadores rurais permanentes" como equivalente a empregados rurais.

Esse é o sentido da palavra "permanentes", utilizada na lei, para caracterizar o objeto modelo da equiparação como relação empregatícia. Não se pode afirmar que a palavra "permanentes", além disso, quis se referir aos empregados contratados por prazo indeterminado. Embora a ideia de permanência possa trazer consigo, em um primeiro momento, a de indeterminação de prazo, há que se conservar a essência do contrato por pequeno prazo, a natureza temporária das atividades contratadas. Portanto, a equivalência

\footnotetext{
${ }^{355}$ Lei n. ${ }^{\circ}$ 5.889/73, art. 17: As normas da presente Lei são aplicáveis, no que couber, aos trabalhadores rurais não compreendidos na definição do art. $2^{\circ}$, que prestem serviços a empregador rural.
} 
remuneratória determinada pelo parágrafo $8^{\circ}$ se refere apenas à remuneração dos contratos por prazo determinado.

O parágrafo $8^{\circ}$ garantiu também os demais direitos de natureza trabalhista. Novamente a legislação deixou em aberto a questão, não explicando exatamente quais são os "demais direitos". Considerando a redação utilizada, não há qualquer exceção a se aplicar. "Demais direitos de natureza trabalhista" equivale a dizer todos os direitos de natureza trabalhistas compatíveis com a lei e não expressamente excluídos por ela. Por se tratar da natureza do próprio contrato, deve-se concluir que a lei garantiu os direitos comuns aos contratos por prazo determinado. Seria contrariar a lógica do instituto querer aplicar as regras próprias da relação de trabalho por prazo indeterminado. A própria norma considera expressamente o contrato como por prazo determinado, prevendo a indeterminação do prazo somente no caso de superação do limite temporal do parágrafo primeiro do art. 14-A.

Tendo por base a natureza temporária das atividades e que a própria lei limita a duração do contrato, não parece coerente incluir entre tais direitos aqueles exclusivos dos contratos por prazo indeterminado, como aviso prévio e indenização de $40 \%$ sobre o saldo do FGTS em caso de dispensa por iniciativa do empregador, sem justa causa. Amauri Mascaro Nascimento ${ }^{356}$ entende de forma diversa, afirmando: “o empregado rural contratado por pequeno prazo terá todos os direitos trabalhistas assegurados aos empregados admitidos a prazo indeterminado".

A falta de clareza da norma permite tal entendimento. Entretanto, parece guardar maior coerência com todo o contexto da nova figura contratual, defender como modelo da equiparação o contrato de emprego por prazo determinado. Há que se levar em consideração a natureza temporária das atividades objeto do contrato, sendo necessário reconhecer que a incidência de direitos como aviso prévio e indenização de $40 \%$ do saldo do FGTS ao término do contrato contrariam a própria lógica do novo modelo contratual. É o caso de se reconhecer a pertinência da equiparação ao contrato de safra.

Estando garantidos os direitos trabalhistas próprios dos contratos por prazo determinado, aplicam-se os artigos 479 e 480 da CLT $^{357}$, no caso de término antecipado do contrato.

\footnotetext{
${ }^{356}$ NASCIMENTO, Amauri Mascaro. Curso de direito do trabalho. 24. ed., cit., p. 740-741.

${ }^{357}$ Conforme artigo $4^{\circ}$ do Decreto n. $.^{\circ} 73.626 / 74$, os artigos 479 e 480 da CLT são aplicáveis às relação de trabalho rural.
} 
A opção do legislador por equiparar a remuneração do trabalhador por pequeno prazo à do empregado por prazo determinado não foi feliz. Equiparar significa igualar o que é diferente, fazer com que se apliquem as mesmas regras a duas figuras díspares. Ocorre que o trabalhador por pequeno prazo e o empregado por prazo determinado não possuem características diversas, não executam tarefas diferentes. Em nada difere o contrato por pequeno prazo do contrato de safra, a não ser pelas diferenciações impostas pela própria lei 11.718/10. E tais diferenciações não afetam a essência da prestação dos serviços, apenas limitam a duração do contrato em dois meses no prazo de um ano, fixam a alíquota da contribuição previdenciária e abrem a possibilidade da substituição da formalização do contrato. A materialização do contrato de trabalho, no dia a dia da prestação laboral, possui características idênticas. Pelo menos não há, na lei, nenhum dispositivo que remeta a alguma diferenciação da subordinação do trabalhador por pequeno prazo, ou que altere substancialmente alguma das características da relação empregatícia. Ou seja, não há na legislação algo que permita diferenciar, na execução das atividades contratadas, o trabalhador por pequeno prazo do empregado por prazo determinado, especialmente o safrista. Apreende-se, em verdade, ser o contrato por pequeno prazo uma espécie do gênero contrato por prazo determinado, ao lado da outra espécie, contrato de safra.

Em outras palavras, os trabalhadores por pequeno prazo são verdadeiros empregados, com todos os direitos pertinentes. Até porque, há que se ressaltar, todos os elementos da relação de emprego estão presentes no contrato do artigo 14-A, com a peculiaridade de se tratar de contrato por prazo determinado, e com limite de até dois meses no período de um ano.

A condição empregatícia da relação do trabalhador contratado por pequeno prazo já fora inclusive constatada no próprio ano de edição da Lei n. ${ }^{\circ}$ 11.718/08, com a elaboração do Decreto n. ${ }^{\circ}$ 6.722/08, que alterou o Regulamento da Previdência Social, incluindo a alínea "r" no inciso I do seu artigo $9^{\circ}$. Por essa alínea, o trabalhador rural contratado na forma do artigo 14-A da Lei n. ${ }^{0}$ 5.889/73, é considerado segurado obrigatório na condição de empregado ${ }^{358}$.

\footnotetext{
${ }^{358}$ Cabe observar que, apesar da mudança no Regulamento da Previdência Social, com a inclusão específica do contrato por pequeno prazo na categoria dos empregados, não houve tal alteração nas leis n. ${ }^{\circ}$ 8.212/91 e $8.213 / 91$. Apesar de a inclusão do trabalhador rural no sistema previdenciário ser uma das principais preocupações demonstradas na exposição de motivos da medida provisória, não se cuidou de alterar as referidas leis, nem no momento da edição da medida provisória, nem no momento da conversão em lei. Tal
} 
Nesse contexto, é correto afirmar que ao trabalhador contratado por pequeno prazo se aplicam apenas duas diferenças com relação aos empregados contratados por prazo determinado: o registro em CTPS e Livro ou Ficha de Registro de Empregados (artigos 29 e 41 da CLT), que passa a ser apenas uma das opções do empregador, e a alíquota da contribuição previdenciária do empregado, que permanece no valor de $8 \%$, sem a progressão da tabela do artigo 20 da Lei $n .^{\circ}$ 8.212/91. Todos os demais direitos the são garantidos e o devem ser não por "equiparação", mas porque, simplesmente, é empregado. A analogia deve ser com o contrato de safra, o contrato por prazo determinado já existente e rotineiramente utilizado nas relações de trabalho rural.

O parágrafo $9^{\circ}$ do art. 14-A determina que todas as parcelas devidas ao trabalhador serão calculadas dia a dia e pagas diretamente a ele, mediante recibo: "§ 90 Todas as parcelas devidas ao trabalhador de que trata este artigo serão calculadas dia a dia e pagas diretamente a ele mediante recibo.".

Não se pode incluir em tais parcelas o valor referente ao FGTS, pois este deverá ser recolhido nos termos da Lei n. ${ }^{\circ}$ 8.036/90, conforme parágrafo seguinte do próprio artigo 14-A. A regra determina a forma de cálculo, não de pagamento. É plenamente possível a incidência da regra do artigo 459 da CLT, ou seja, a estipulação do pagamento por mês. Até porque o artigo 459 da CLT é aplicável às relações de trabalho rural, conforme artigo $4^{\text {o }}$ do Regulamento da Lei n. ${ }^{\circ}$ 5.889/73, aprovado pelo Decreto n. ${ }^{\circ} 73.626 / 74$. Seria carente de razoabilidade a interpretação que buscasse obrigar o empregador a efetuar um pagamento por dia, a cada empregado, preenchendo e guardando recibos, a cada dia, colhendo a respectiva assinatura de cada trabalhador. Tal interpretação contraria o próprio espírito da norma, de facilitação e redução da burocracia.

Ademais, a literalidade da norma se referiu expressamente ao cálculo, não ao pagamento. Caso a intenção fosse obrigar o empregador a efetuar pagamentos diários, a norma teria utilizado a expressão "serão pagas dia a dia”, e não "serão calculadas dia a dia" 359 .

inclusão resta definida, portanto, somente pela própria lei 11.718/08, determinando a filiação e inscrição a partir da inclusão em GFIP, e pelo Regulamento da Previdência Social, mas não reconhecida expressamente pela Lei n. $^{\circ}$ 8212/91, nem pela Lei 8.213/91. Sem a alteração em tais leis, cabe a interpretação de que o trabalhador contratado por pequeno prazo está abarcado pelo conceito da alínea "a" do inciso I do artigo 12 da Lei n. ${ }^{\circ} 8.212 / 91$, e pelo conceito da alínea "a" do inciso I do artigo 11 da Lei n. ${ }^{\circ}$ 8.213/91, na condição de empregado.

${ }^{359}$ Ulisses Otávio Elias dos Santos não atenta para esse detalhe, afirmando que os "direitos trabalhistas do laborista serão devidos e pagos diretamente a ele ao final do dia." SANTOS, Ulisses Otávio Elias dos. op. cit., p. 22. 
Por outro lado, considerando que a própria lei garante ao trabalhador contratado por pequeno prazo, "além da remuneração equivalente à do trabalhador rural permanente, os demais direitos de natureza trabalhista”, parece evidente que a forma de cálculo não deve reduzir tais direitos. Ou seja, caso a maneira de cálculo "dia a dia" implique em montante inferior ao que seria obtido com o cálculo feito da maneira tradicional, parece correto que o trabalhador receba o montante obtido por este último cálculo. Trata-se inclusive de se respeitar os princípios justrabalhistas que inspiram a interpretação das normas laborais, observando-se também o princípio isonômico que deve permear as relações trabalhistas.

Na parte final, o parágrafo afirma que o pagamento deve ser feito diretamente ao empregado, mediante recibo. O comando é desnecessário, pois já se exige o pagamento feito diretamente ao empregado, mediante recibo, conforme artigos 457 e 464 da CLT. Trata-se, sem dúvida, de um alerta ao empregador, que certamente será obrigado a pagar novamente os salários que vier a pagar a intermediário, ou seja, não diretamente ao empregado.

A intenção do legislador foi outra, como se percebe a partir da exposição de motivos:

\footnotetext{
"Os direitos trabalhistas do trabalhador serão devidos e pagos diretamente a ele, mediante adição à remuneração acordada, de um valor proporcional àquela, que corresponda à soma dos valores referentes a férias, adicional de férias, décimo-terceiro salário, horas extras, horas in itinere."
}

A intenção do legislador foi instituir o chamado pagamento complessivo. Tal intenção não atinge o objetivo de facilitar os procedimentos para o empregador carente de infraestrutura administrativa mínima, ou de lhe reduzir a burocracia. Devendo ser respeitado o direito do trabalhador a cada verba trabalhista, a adição de um único valor correspondente à soma de cada parcela não iria reduzir a burocracia para o empregador, que permaneceria obrigado a realizar corretamente os cálculos para determinar o valor correspondente à soma de cada parcela. Além de não reduzir os custos nem as tarefas do empregador, a intenção do legislador iria prejudicar a transparência da relação jurídica, podendo fomentar desconfianças e conflitos.

A discriminação das verbas trabalhistas, uma a uma, no recibo, contribui para a transparência contratual, é imprescindível para que o empregado possa conferir, ou ao menos tentar conferir, o respeito aos seus direitos. A indicação de cada verba no recibo de 
pagamento do salário é fonte de harmonização e pacificação da relação trabalhista, não devendo ser afastada $^{360}$.

Ademais, há que se atentar para a Súmula n. ${ }^{\circ} 91$ do TST, que proíbe o chamado salário complessivo estipulado por cláusula contratual. Não parece seguro ou salutar permitir o pagamento complessivo estipulado por lei, unicamente para esse tipo novo de contratação. Estaria configurado, de início, desrespeito ao princípio da isonomia, havendo um tratamento diferenciado da legislação somente para o trabalhador contratado por pequeno prazo, sem motivo legítimo a justificar tal diferenciação.

De qualquer modo, a redação da norma sequer permite a interpretação pretendida pela exposição de motivos. Pagamento calculado dia a dia e efetuado diretamente ao empregado não equivale a pagamento complessivo. A interpretação da norma não deve se ater unicamente à intenção do legislador, ainda que estampada na exposição de motivos, mas deve privilegiar os aspectos sistemáticos do ordenamento jurídico, cabendo à norma se harmonizar com as demais preexistentes e com os princípios jurídicos norteadores de todo o sistema, ainda que seja necessário abandonar os objetivos apresentados na exposição de motivos. O parágrafo $9^{\circ}$ determina, portanto, apenas a forma de cálculo das verbas, que não poderá prejudicar o empregado, e que o pagamento deve ser efetuado sem intermediários, diretamente a ele. Trata-se de mera repetição desnecessária de conceitos e direitos já garantidos. Novamente, peca o legislador pela falta de técnica, pois sequer os objetivos pretendidos foram alcançados.

Por fim, o parágrafo $10^{\circ}$ do artigo 14-A estabelece que o FGTS deverá ser recolhido e levantado nos termos da Lei n. ${ }^{\circ}$ 8.036/90, disposição que apenas reforça um direito que já estava garantido anteriormente, quando todos os demais direitos trabalhistas foram assegurados ao empregado contratado por pequeno prazo:

$\S$ 10. O Fundo de Garantia do Tempo de Serviço - FGTS deverá ser recolhido e poderá ser levantado nos termos da Lei $\mathrm{n}^{0} 8.036$, de 11 de maio de 1990.

No comando normativo está contida proibição de pagamento direto ao empregado do valor relativo ao FGTS. Aplica-se naturalmente o inciso IX do artigo 20 da Lei n. ${ }^{\circ}$

\footnotetext{
${ }^{360}$ Zéu Palmeira Sobrinho também defende que as parcelas sejam especificamente indicadas: "Parcelas trabalhistas calculadas diariamente e quitadas imediatamente contra recibo no qual estejam especificados os direitos e os respectivos valores e períodos." PALMEIRA SOBRINHO, Zéu. op. cit., p. 13. No mesmo sentido afirma Ulisses Otávio Elias dos Santos: “todas essas verbas devem ser bem especificadas no recibo.” SANTOS, Ulisses Otávio Elias dos. op. cit., p. 22.
} 
8036/90, podendo o trabalhador sacar o valor depositado em sua conta vinculada ao término normal do contrato.

Observa-se, por fim, a previsão genérica do artigo 18 da Lei n. ${ }^{\circ}$ 5.889/73, segundo o qual as infrações aos dispositivos da lei serão punidas com multa de $\mathrm{R} \$ 380,00$ (trezentos e oitenta reais) por empregado em situação irregular. Estando a nova figura contratual inserida na referida Lei, o empregador que deixar de observar qualquer dos seus dispositivos estará sujeito à penalidade aplicada pela Auditoria-Fiscal do Trabalho.

\subsection{Denominação}

Verificadas as principais características do novo contrato, é possível analisar a denominação eleita pela legislação, "contrato de trabalhador rural por pequeno prazo", que não comportou, até o momento, críticas ou discussões doutrinárias. De fato, a inovação legislativa tratou de um contrato, passível de celebração por trabalhador rural, tendo como característica central a curta duração. O legislador optou por se referir não ao objeto do contrato, a prestação do trabalho, mas a um dos sujeitos, o "trabalhador". A norma evitou o termo "empregado", palavra que afastaria qualquer discussão a respeito da natureza empregatícia da relação.

Levando em consideração que a relação de emprego é uma das muitas relações de trabalho possíveis, Jose Martins Catharino ${ }^{361}$ marcou a diferença entre contrato de trabalho e contrato de emprego, cabendo somente a este designar a relação subordinada. Amauri Mascaro Nascimento atenta para a mesma diferenciação ${ }^{362}$. Já a distinção feita por Délio

\footnotetext{
${ }^{361}$ Nas palavras do autor: "E quem ousará afirmar não ser possível, em futuro próximo, falar-se em contrato de emprego como espécie do contrato de trabalho? Para nós, desde já, por força mesmo do expansionismo do Direito do Trabalho, cuja denominação se faz dia a dia menos defeituosa por excesso". (...) Em que pese a generalizada aceitação do nome contrato de trabalho, preferimos o de contrato de emprego. No Brasil, não temos dúvidas de ser a melhor, pelas razões a seguir alinhadas”. CATHARINO, José Martins. op. cit., v. 1, p.265-266.

362 "Convém no início deixar clara a diferença entre contratos de trabalho e contratos de emprego, tomando, quanto a estes últimos, a terminologia proposta há muitos anos por José Martins Catharino e que agora, mais ainda que na época em que foi proposta, mostra-se de grande utilidade.

A expressão contratos de trabalho abrange contratos aos quais não é aplicada a legislação trabalhista, porque não se enquadram em princípio nos parâmetros definidos pelos arts. $2^{\circ}$ e $3^{\circ}$ da CLT." NASCIMENTO, Amauri Mascaro. Curso de direito do trabalho. 24. ed., cit., p. 546.
} 
Maranhão ${ }^{363}$ utiliza a expressão "contrato de trabalho stricto sensu" para se referir ao trabalho subordinado.

O legislador, entretanto, não obedeceu à melhor técnica jurídica, utilizando indiscriminadamente o termo "trabalhador" ou a expressão "contrato de trabalho", para se referir a situações de emprego. Trata-se de situação comum, a própria CLT utiliza "contrato de trabalho", não "contrato de trabalho stricto sensu” ou "contrato de emprego", quando se refere à relação de trabalho subordinado: art. 442, caput: "Contrato individual de trabalho é o acordo tácito ou expresso, correspondente à relação de emprego".

Assim, não é possível indicar a relação de fato existente somente a partir da denominação utilizada pela legislação. Há que se buscar na realidade os seus elementos característicos, ou deixar que a legislação, não ao nominar o instituto, mas ao definir suas características, afaste esta ou aquela qualidade empregatícia. Por exemplo, a legislação referente às cooperativas cuidou de expressamente afastar o vínculo empregatício ${ }^{364}$.

No contrato por pequeno prazo a legislação não afastou expressamente o vínculo empregatício, nem se referiu a nenhum elemento fático que pudesse descaracterizá-lo. Ao contrário, mencionou a onerosidade e a vinculação direta, sem intermediários, entre o produtor rural e o trabalhador, características próprias, embora não exclusivas, da relação de emprego. Nas demais características apontadas pela legislação não há motivo para afirmar que o contrato não corresponde à relação de emprego. A lei n. ${ }^{0}$ 11.718/09 não afastou a subordinação, a não eventualidade nem a pessoalidade. Desse modo, o novo contrato espelha relação de emprego, ainda que a legislação tenha evitado a palavra “empregado", utilizando "trabalhador".

Embora a natureza dos serviços contratados seja temporária, não se deve utilizar a denominação trabalho temporário rural, pois, por conta da Lei n. ${ }^{\circ}$ 6.019/74, já está arraigada no meio jurídico a vinculação da expressão "trabalho temporário" à relação triangular, com intermediação de mão de obra por empresa previamente registrada, a fim de satisfazer necessidades decorrentes de acréscimo extraordinário de serviços ou substituição regular de pessoal, circunstâncias estranhas às reguladas pelo contrato de pequeno prazo.

\footnotetext{
363“"A expressão contrato de trabalho designa um gênero muito amplo, que compreende todo contrato pelo qual uma pessoa se obriga a uma prestação de trabalho em favor de outra. O contrato, objeto deste Capítulo, é o contrato de trabalho stricto sensu, ou seja, o contrato de trabalho subordinado." SÜSSEKIND, Arnaldo; MARANHÃO, Délio; VIANNA, Segadas; TEIXEIRA FILHO, João de Lima. op. cit., v. 1, p. 229.

364 Art. 442, parágrafo único da CLT.
} 


\subsection{Análise crítica}

A figura contratual resultante da Medida Provisória n. ${ }^{\circ}$ 410/07, posteriormente convertida na Lei . $^{\circ} 11.718 / 08$, sofre de graves contradições.

O legislador apontou, na exposição de motivos, preocupação com a histórica exclusão do trabalhador rural do sistema previdenciário, motivada em grande parte pela falta de formalização das relações rurais de trabalho ${ }^{365}$. Duas ordens de causas do baixo índice de formalização foram apresentadas. De um lado o comportamento e a falta de conscientização dos empregadores, de outro, a carência de estrutura administrativa mínima que lhes permita cumprir as normas trabalhistas e previdenciárias ${ }^{366}$. Foi desprezada, já na exposição de motivos, a causa possivelmente de maior destaque, e certamente mais determinante do comportamento dos empregadores: os altos custos que a formalização das relações de trabalho representa.

Parte desses custos se concentra na burocracia e na necessária estrutura administrativa para se cumprir as regras trabalhistas e previdenciárias. Pertinente, portanto, a intenção de se reduzir a burocracia. Entretanto, há ainda outra grande parte dos custos, representada pelos encargos previdenciários e trabalhistas em geral. Nesse sentido, o avanço tímido e único foi a fixação da alíquota da contribuição previdenciária do empregado em $8 \%$, porcentagem mínima da tabela progressiva do artigo 20 da Lei n. ${ }^{\circ}$ 8.212/91. Trata-se de acanhada redução de custos, que atinge diretamente não os gastos do empregador, mas o ganho imediato do trabalhador, que terá desconto menor em seu salário. No mais, não se reduziu custo algum do empregador, que arca com os mesmos

\footnotetext{
${ }^{365}$ Trecho da exposição de motivos: "Com a edição das Leis n- 8.212 e $n^{\circ} 8.213$, ambas de 24 de julho de 1991, os trabalhadores rurais foram incorporados ao Regime Geral de Previdência Social - RGPS, em cumprimento a disposição constitucional que assegurou a eles os mesmos direitos até então dispensados aos trabalhadores urbanos. No mencionado art. 143 da Lei n- 8.213, de 1991, foi estabelecida regra de transição, até 24 de julho de 2006, para assegurar a esses trabalhadores o acesso aos benefícios. Esperava-se que nesse tempo houvesse mudança do comportamento dos empregadores da área rural quanto à formalização das relações do trabalho. No entanto, a situação de informalidade no setor não mudou".

${ }^{366}$ Trecho da exposição de motivos: "Argumenta-se, ainda, que a maioria dos produtores rurais, especialmente os pequenos produtores e os que trabalham em regime de economia familiar não possuem estrutura administrativa mínima que lhes permita atender aos imperativos legais e regulamentares estabelecidos pelas legislações trabalhista e previdenciária. Agrava a situação o fato de as contratações serem, em sua maioria, para serviços de curta duração.Vossa Excelência é conhecedor de toda a problemática e, também, dos esforços envidados por parte destes Ministérios para conscientizar o empregador da área rural da importância da formalização das relações do trabalho no campo. Não obstante os esforços despendidos, na prática, pouco se avançou e esses trabalhadores, já bastante sacrificados pelo tipo e condições de trabalho, não podem ficar sem amparo previdenciário.”
} 
gastos do contrato de safra, por exemplo. Há, em verdade, a necessidade de se buscar a autorização em negociação coletiva para a dispensa do registro, o que pode até mesmo aumentar os custos.

Aponta-se como primeira desvantagem, ou aspecto negativo, portanto, a praticamente inexistente redução de custos para o empregador. Sequer a alíquota do FGTS, reduzida em outras oportunidades, como no contrato de aprendizagem, ou no contrato previsto pela Lei n. ${ }^{\circ} 9.601 / 98$, foi atenuada.

Além de a redução de custos ter sido ínfima, a tentativa de redução da burocracia não teve êxito. De início, a única tarefa do empregador que foi afastada foi o registro do empregado em Livro ou Ficha de Registro e a anotação do contrato em CTPS. Ainda assim será necessário haver autorização em negociação coletiva e providenciar contrato escrito, em duas vias. Apenas a aplicação dos artigos 29 e 41 da CLT é abordada pela nova legislação, todos os demais passos burocráticos não são sequer mencionados. Considerando que o trabalhador possui a condição de empregado, como o próprio Regulamento da Previdência Social reconhece, e que lhe são garantidos todos os demais direitos trabalhistas, é inevitável concluir que o empregador deverá tratá-lo como empregado em todos os aspectos. Excepcionam-se exclusivamente os quesitos expressamente afastados pela legislação. Nesse contexto, será necessário, por exemplo, que o empregador informe o CAGED (Cadastro Geral de Empregados e Desempregados ${ }^{367}$ ) e a RAIS (Relação Anual de Informações Sociais ${ }^{368}$ ), além da expressamente exigida inclusão dos trabalhadores em GFIP. A simples não aplicação dos artigos 41 e 29 da CLT constitui, então, redução por demais acanhada da burocracia que envolve a contratação de empregados.

Observa-se que o registro em CTPS e em livro ou ficha próprios é menos burocrático e complexo que a inclusão do trabalhador em GFIP. Os registros independem

\footnotetext{
${ }^{367}$ O Cadastro Geral de Empregados e Desempregados está regulado pela Lei n. ${ }^{\circ} 4.923 / 65$ e legislação esparsa. Segundo o "Manual do CAGED", (MINISTÉRIO DO TRABALHO E EMRPEGO. Manual de orientação do CAGED. Cadastro geral de empregados e desempregados. Lei $n$. 4923/65. Brasília, DF, 2010. Disponível em: <http://www.caged.gov.br/downloads/caged/Manual_CAGED_2010_versaoACI101.pdf>), devem ser declarados os "trabalhadores regidos pelo Estatuto do Trabalhador Rural (Lei $n .{ }^{o}$ 5.889, de 08 de junho de 1973)."

${ }^{368}$ A Relação Anual de Informações Sociais está regulada pelo Decreto n. ${ }^{\circ} 76.900 / 75$ e legislação esparsa. Conforme MINISTÉRIO DO TRABALHO E EMPREGO. Manual da RAIS. Disponível em: <http://portal.mte.gov.br/rais/manual-da-rais-2010.htm>, estão obrigados a declarar a RAIS os "empregadores rurais pessoas físicas que mantiveram empregados no ano base". Ainda segundo o manual, entre as pessoas que devem ser relacionadas constam os "trabalhadores regidos pelo Estatuto do Trabalhador Rural (Lei n. ${ }^{\circ}$ 5.889, de 08 de junho de 1973)."
} 
da aferição da remuneração, geralmente variável, efetivamente percebida no período de apuração, de programas de informática ou de cálculos previdenciários. Podem ser feitos a caneta, de próprio punho. Ao contrário, a inclusão em GFIP demanda, no mínimo, acesso a recursos de informática e o cálculo do valor da remuneração a ser paga e da contribuição a ser descontada do trabalhador.

Considerando que o objetivo seria facilitar a contratação para pequenos produtores rurais, carentes de estrutura administrativa mínima, é ineficaz dispensá-los de registrar os empregados, mas mantê-los obrigados a incluir os trabalhadores em GFIP. E ainda há a necessidade de identificá-los propriamente na GFIP, utilizando o mecanismo a ser criado pela Previdência Social, conforme $\S 2^{\circ}$ do artigo 14-A. A estrutura administrativa necessária para tal inclusão é maior que a necessária para efetuar os registros. Se o empregador permanece obrigado a efetuar o mais complicado, deixar de fazer o menos complicado não lhe permite possuir estrutura administrativa menor, menos aparelhada.

Além da redução da burocracia ter sido demasiado pequena, a legislação, ao dispensar o empregador de proceder aos registros em CTPS e em Livro ou Ficha, criou-lhe uma obrigação nova, que substituiu a anterior, impondo-lhe o dever de providenciar um contrato escrito, com autorização do sindicato profissional, onde constem todos os dados que já constariam do Livro ou Ficha de Registro de Empregados. Conclui-se que a legislação, ao invés de reduzir, substituiu a burocracia. Há verdadeira complicação, não simplificação, para a formalização do vínculo trabalhista.

Como visto acima, a nova figura contratual, além de não ter reduzido significativamente os custos, não se apresenta capaz de diminuir a burocracia. Certamente não será capaz, por outro lado, de contribuir para a conscientização e mudança de comportamento dos empregadores, principalmente os mal intencionados.

Trata-se de caso único em que o contrato de emprego, com todos os direitos trabalhistas que lhe são próprios, não precisa ser anotado em CTPS e Livro ou Ficha de Registro de Empregados. Considerando que a anotação em CTPS é o principal meio de prova do empregado contra o empregador, conforme artigos 13 e 40 da CLT, e que o Livro ou Ficha de Registro é um dos principais meios de que a Auditoria-Fiscal do Trabalho dispõe para verificar, de imediato, a existência ou não de mão de obra informal, não é difícil prever que o empregador mal intencionado tentará buscar meios de utilizar tal figura contratual para escapar de eventual sentença contrária, ou de eventual autuação pela Auditoria-Fiscal do Trabalho. 
É de se observar que a norma, ao dar ao empregador a opção de não registrar os empregados, exige somente um contrato em duas vias. Percebe-se a fragilidade da situação do empregado. A CTPS é documento pessoal do empregado, sua retenção dolosa pelo empregador é severamente punida pelo ordenamento jurídico ${ }^{369}$. As duas vias do contrato podem ser mais facilmente, mais impunemente, retidas pelo empregador mal intencionado. Nesse caso, o rurícola ficaria sem comprovação documental alguma da relação trabalhista.

O Livro ou as Fichas de Registro de Empregados devem observar uma sequência de registros, e podem ser exigidos de imediato pela Fiscalização do Trabalho. Ainda que o contrato escrito seja também exigido de imediato pela fiscalização, resta a possibilidade de ser mantido "na gaveta", como bem observado por Gustavo Filipe Barbosa Garcia, ${ }^{370}$ sendo apresentado, e até mesmo preenchido, somente se a fiscalização se fizer presente. Natália Sena e Andressa Batista de Oliveira ${ }^{371}$ observam a facilidade da fraude, lembrando que, em função da sua pouca instrução, sendo facilmente ludibriado, ou em função do seu maior grau de dependência econômica, o trabalhador rural pode assinar o contrato em branco. Permite-se então que o empregador, caso seja visitado pela fiscalização, coloque a data que melhor lhe convenha, impedindo a configuração da duração da relação laboral por lapso temporal superior aos dois meses mencionados no parágrafo $1^{\circ}$ do artigo.

A dispensa da anotação em CTPS e registro em livro ou ficha é, sem dúvida, fator que facilita a fraude. Zéu Palmeira Sobrinho ${ }^{372}$ observa haver também a possibilidade de fraude pelo empregado, que se alia ao empregador e aceita a condição precarizante para não deixar de receber parcelas de seguro-desemprego, benefícios previdenciários por invalidez, ou outros auxílios governamentais que, na condição de empregado, não poderia mais receber.

Pode ser apontada então como outra desvantagem da nova figura contratual a facilitação que ela promove para a fraude. Essa ideia se reforça com o fato anteriormente apontado, qual seja, a ineficiência que a facultatividade do registro representa enquanto redução da burocracia e dos custos. Sendo garantidos todos os demais direitos aos trabalhadores, por via reflexa, são mantidos todos os demais deveres do empregador. Este,

\footnotetext{
${ }^{369}$ Além de configurar infração administrativa, conforme artigo 53 da CLT, a retenção da CTPS pelo empregador, com intuito de mantê-lo no local de trabalho, pode configurar crime de redução a condição análoga à de escravo, conforme artigo 149 do Código Penal. A retenção da CTPS para impedir o desligamento dos serviços pode configurar crime de frustração de direito assegurado por lei trabalhista, conforme artigo 203 do Código Penal.

${ }^{370}$ GARCIA, Gustavo Filipe Barbosa. Curso de direito do trabalho, cit., p. 212 e ss.

${ }^{371}$ SENA, Natália; OLIVEIRA, Andressa Batista de. op. cit., p. 521-524.

${ }^{372}$ PALMEIRA SOBRINHO, Zéu. op. cit., p. 13.
} 
mesmo sem estar obrigado a registrar os trabalhadores, mantém-se obrigado a todos os demais custos representados pela relação empregatícia, deixando de gastar apenas a "tinta da caneta" que seria usada para os registros. Para o empregador bem intencionado, não há vantagem, portanto, em deixar de registrar. Mas para o mal intencionado, tal possibilidade pode significar um atalho para a prática da fraude. A nova legislação, destarte, em nada avança para a mudança de comportamento dos empregadores mal intencionados.

Já para a mudança de comportamento dos empregadores bem intencionados, acredita-se ser necessária a redução da burocracia de maneira clara, com segurança jurídica, ao lado da redução dos custos que a contratação de empregados representa. No entanto, a nova figura contratual, ao que parece, não foi capaz de reduzir a burocracia, está repleta de inconstitucionalidades e não representou redução de custos.

A facultatividade do registro, além de não contribuir para os objetivos mencionados na exposição de motivos, padece de grave inconstitucionalidade. Não há como negar razão ao que afirma Gustavo Filipe Barbosa Garcia ${ }^{373}$, apontando a incompatibilidade da regra com o princípio da igualdade, afrontando tanto o caput do art. $5^{\circ}$ da Constituição da República, quanto à equiparação entre trabalhadores urbanos e rurais, inserida no caput do seu artigo $7^{\circ}$. Se a todos os empregados é garantido o direito a ter na CTPS a anotação do contrato de trabalho, bem como ser registrado em Livro ou Ficha de Registro de Empregados, não há razão para a criação dessa única exceção. Mesmo os empregados contratados por prazo determinado possuem tal direito. Não há, entre os elementos e circunstâncias fáticos abrangidos pela lei, nada que caracterize uma discrepância tão grande desses trabalhadores, a ponto de justificar tratamento legal tão diferenciado. Ou seja, ao permitir a ausência de registro, a lei trata de maneira diferente situações que não se caracterizam por tal diferença, sendo inegável o prejuízo ao princípio da isonomia. Segundo o autor ${ }^{374}$, a anotação em CTPS e o registro em Livro ou Ficha são direitos indisponíveis dos empregados, garantidos por norma de ordem pública. Não estariam, então, no rol constitucional de possibilidades de flexibilização, afrontando-se os princípios constitucionais do não retrocesso social e da melhoria das condições sociais dos trabalhadores, previsto no artigo $7^{\circ}$, caput, da Constituição da República. Está correta tal

\footnotetext{
${ }^{373}$ GARCIA, Gustavo Filipe Barbosa. Curso de direito do trabalho, cit., p. 213.

${ }^{374}$ GARCIA, Gustavo Filipe Barbosa. Curso de direito do trabalho, cit., p. 213-214.
} 
análise, também observada por outros doutrinadores ${ }^{375}$, que tecem pesadas críticas à nova figura contratual.

Com relação a aspectos práticos, Gustavo Filipe Barbosa Garcia ${ }^{376}$ aponta ser da “tradição e da sistemática do Direito do Trabalho no Brasil” a anotação do contrato na CTPS e no Livro ou Ficha de Registro de empregados. Há dificuldades originadas pela dispensa de tais registros para os empregados. É mais provável que o trabalhador perca o contrato escrito, documento avulso, que a CTPS, documento a que se dá tradicionalmente maior importância. Nesse caso, o trabalhador poderá enfrentar dificuldades perante o INSS, anos à frente, caso tenha que demonstrar a relação de trabalho havida.

Tal crítica leva em consideração que a Previdência Social pode exigir do trabalhador a demonstração do exercício de atividade remunerada. Entretanto, como visto acima, o exercício de atividade remunerada não basta para caracterizar a filiação do trabalhador ao regime, nesse tipo de contrato, sendo necessária a sua inclusão em GFIP. Somente após tal regra ser extirpada do ordenamento jurídico, por evidente inconstitucionalidade, garantindo-se a filiação automática a partir do simples exercício de atividade remunerada, é que caberia então à Previdência Social exigir do trabalhador a demonstração da relação de trabalhado ocorrida. Nesse contexto, ganha relevância a crítica do autor, pois, mesmo que seja afastada do ordenamento jurídico a norma que condiciona a filiação do trabalhador ao ato burocrático de inclusão em GFIP, ainda assim permanecerá a dificuldade para o filiado ter acesso aos seus direitos previdenciários. Se para os trabalhadores em geral bastaria guardar e apresentar ao INSS a CTPS, com toda a sua história laboral, no presente caso, o trabalhador contratado por pequeno prazo precisaria

\footnotetext{
${ }^{375}$ Raquel Pereira Furtado afirma: “Essas alterações na Lei do Trabalhador Rural facilitam a exploração desmedida, sem que o trabalhador tenha direitos. Afora ser um retrocesso, é de extrema discriminação dos trabalhadores rurais em relação aos urbanos, pois fere o princípio constitucional da isonomia. Também acaba com conquistas históricas do trabalhador e fere o direito de ter a carteira de trabalho assinada, fato que reflete na contagem do tempo de serviço para aposentadoria. (...) A dispensa de anotação dos contratos de trabalho rural estimulará a informalidade no meio rural. A alteração da Lei do Trabalho Rural também criará dificuldades à fiscalização realizada pelo Ministério do Trabalho. (...) As modificações introduzidas pela referida Medida Provisória, além de agredirem princípios basilares dos direitos dos trabalhadores causando a informalidade e a precarização do emprego, demonstram que as relações trabalhistas no campo voltaram a ser menos importantes do que as dos centros urbanos". FURTADO, Raquel Pereira. op. cit., p. 80-81. Zéu Palmeira Sobrinho adota postura semelhante: "Em suma, a medida governamental, além de desvalorizar um instrumento simbólico das relações de trabalho formal no Brasil, sinaliza para o desmantelamento das poucas e frágeis exigências que são representativas para a defesa do trabalhador e para o combate à sonegação de direitos." PALMEIRA SOBRINHO, Zéu. op. cit., p. 14. Natália Sena e Andressa Batista de Oliveira são enfáticas: "Conclui-se que a MP 410/07 possui nítido perfil precarizante dos direitos trabalhistas. Constitui um convite à fraude.” SENA, Natália; OLIVEIRA, Andressa Batista de. op. cit., p. 524.

${ }^{376}$ GARCIA, Gustavo Filipe Barbosa. Curso de direito do trabalho, cit., p. 212-213.
} 
guardar não apenas a CTPS, mas também o contrato escrito, preservado legível e em bom estado, para apresentar ao INSS.

Percebe-se profunda contradição do legislador. Pretendeu combater a exclusão dos trabalhadores do regime previdenciário, reduzindo a burocracia, mas impôs dificuldades para os trabalhadores, não apenas no quesito filiação, mas também no momento de comprovar o exercício de atividade remunerada. É possível concluir que, apesar de a intenção declarada na exposição de motivos ser o combate à exclusão dos trabalhadores rurais do regime previdenciário, o objetivo perseguido com a edição da norma foi apenas a dispensa do empregador de cumprir os ditames dos artigos 29 e 41 da CLT, sem maiores preocupações com a efetiva inclusão dos trabalhadores rurais no sistema previdenciário.

Gustavo Filipe Barbosa Garcia ${ }^{377}$ aponta ainda outros obstáculos causados pela falta de anotação em CTPS e de registro em livro ou ficha. Indica dificuldade para a atuação dos órgãos de fiscalização do trabalho, considerando a hipótese de o contrato escrito se tornar mero "contrato de gaveta", sendo utilizado pelo empregador somente se a fiscalização do trabalho se fizer presente. Caso não haja fiscalização, o contrato poderia ser descartado após a prestação laboral, sem produzir qualquer efeito, restando ao trabalhador a situação de ter trabalhado sem registro, sem o mínimo respeito aos seus direitos. Conclui o autor que a dispensa do registro configura desrespeito ao princípio isonômico e ofensa ao caput do artigo $7^{\circ}$ da Constituição da República, que garantiu aos trabalhadores rurais o mesmo tratamento dado aos trabalhadores urbanos. Ademais, continua o autor, a flexibilização dos direitos trabalhistas é limitada pelas normas constitucionais, que não abrigam a retirada do direito indisponível ao registro em CTPS e Livro ou Ficha de Registro de Empregados.

A relevância da CTPS é marcada na exposição de motivos da própria CLT, como bem observado por Natália Sena e Andressa Batista de Oliveira ${ }^{378}$. As autoras, além de indicarem essa inconstitucionalidade material, apontam também inconstitucionalidade formal da Medida Provisória que introduziu a figura contratual no ordenamento jurídico, pois não estariam presentes os requisitos de relevância e urgência, previstos no artigo 62 da Constituição da República. Afirmam também que a iniciativa do Presidente da República em adotar a Medida Provisória n. ${ }^{\circ} 410 / 07$ ofenderia as regras constitucionais sobre

\footnotetext{
${ }^{377}$ GARCIA, Gustavo Filipe Barbosa. Curso de direito do trabalho, cit., p. 213.

${ }^{378}$ SENA, Natália; OLIVEIRA, Andressa Batista de. op. cit., p. 522.
} 
iniciativa, pois, segundo seu entendimento, somente à "União, por meio do Congresso Nacional, compete legislar sobre o direito do trabalho".

Nem todas as críticas das autoras merecem acolhida, pois ao Poder Executivo cabe avaliar se estão ou não presentes os pressupostos de relevância e urgência. Ademais, o artigo 62 da Lei Maior, ao permitir a adoção de medidas provisórias pelo Presidente da República, cuidou de mencionar expressamente as limitações quanto à matéria, no seu parágrafo primeiro. A norma vedou a edição de medidas provisórias sobre direito eleitoral, penal, processual penal e processual civil, não sobre direito do trabalho. Não há, portanto, vício com relação à iniciativa da Medida Provisória.

Não obstante, permanecem pertinentes as outras críticas apontadas pela doutrina, restando inequívoca a inconstitucionalidade da regra que afasta a obrigatoriedade dos registros impostos pelos artigos 29 e 41 da CLT, por ofensa direta ao princípio da isonomia.

Poder-se-ia argumentar que os trabalhadores contratados nos moldes do artigo 14-A da Lei n. ${ }^{\circ}$ 5.889/73 não são empregados e, portanto, não haveria ofensa à isonomia, já que os trabalhadores não empregados não são registrados. Entretanto, o argumento falha ao desprezar que, no contrato em estudo, estão presentes todos os elementos da relação de emprego e, ademais, a própria legislação considerou tais trabalhadores como empregados, ao lhes garantir os demais direitos trabalhistas dos trabalhadores rurais permanentes. Sedimentando a questão, o Regulamento da Previdência Social foi alterado, passando a declarar expressamente a condição de empregado do trabalhador contratado por pequeno prazo. Conclui-se, indubitavelmente, que o vínculo formado é o de emprego, restando contrária ao princípio da isonomia a permissão do não registro. Ademais, se não fosse relação de emprego, não seria necessário dispensar a anotação em CTPS e registro em livro ou ficha.

Mais alguns aspectos negativos se apresentam, portanto. Além de não reduzir custos, não reduzir burocracia, aproximar o empregador da fraude, a nova figura contratual, ao dispensar o registro, agrava-se de inconstitucionalidade material, por ofensa ao princípio da igualdade e do não retrocesso social. Prejudica o relacionamento do trabalhador com o sistema previdenciário, nos momentos de filiação e de comprovação de tempo de trabalho, e dificulta a ação fiscalizadora do Estado.

Ao empregador torna-se arriscado empreender negócios jurídicos sob a égide de uma norma marcada pela inconstitucionalidade, passível de ser declarada inconstitucional 
pelo Poder Judiciário, de forma incidental ou concentrada, figurando-se grande insegurança jurídica.

Em suma, a nova figura contratual apresenta uma série de aspectos negativos, desde não alcançar os objetivos alardeados na exposição de motivos, até a inconstitucionalidade manifesta de seus principais dispositivos, passando pela facilitação da fraude. Nesse contexto, há grande dificuldade em identificar aspectos positivos do novo contrato por pequeno prazo.

Para os produtores rurais não há vantagem. A possibilidade de se contratar empregados por tempo determinado, para atividades de natureza temporária, ainda que não vinculadas à safra, já era possível, pois o artigo 443, § $2^{\circ}$, alínea "a" da CLT sempre foi aplicável às relações de trabalho rural, conforme Decreto n. ${ }^{\circ} 73.626 / 74$, art. $4^{\circ}$. Nesse sentido, a nova figura contratual não representa mecanismo eficiente para reduzir as taxas de informalidade no campo, ou para aumentar o quantitativo de mão de obra utilizada.

Aos trabalhadores há a potencial vantagem de representar, a nova figura contratual, uma chance para a formalização do vínculo de emprego. Para o empregado mantido na total informalidade, sem direito algum, a contratação sob as regras do artigo 14-A da Lei n. ${ }^{\circ}$ 5.889/73 representa inegável vantagem. Entretanto, a possibilidade não é maior que a utilização do contrato de safra ou do contrato por prazo determinado previsto na alínea "a" do $\S 2^{\circ}$ do art. 443 da CLT. As desvantagens, ao contrário, são gritantes. A inconstitucionalidade do novo modelo contratual reside justamente no tratamento desigual e prejudicial oferecido ao trabalhador, restando dificultada a filiação ao sistema previdenciário e facilitada a fraude.

Perde também a sociedade, pois o contrato por pequeno prazo, ao permitir a ausência de registro e de anotação em CTPS se apresenta como potencial fonte de conflitos e de insegurança jurídica, dada à inconstitucionalidade material de que padece. Além de representar, tal possibilidade, um “convite à fraude", nas palavras de Natália Sena e Andressa Batista de Oliveira ${ }^{379}$, sobrecarregando as instituições estatais responsáveis pela tarefa de zelar pelo respeito aos direitos trabalhistas e dignidade do trabalhador rural, Justiça do Trabalho, do Ministério Público do Trabalho e Auditoria-Fiscal do Trabalho.

${ }^{379}$ Id. Ibid., p. 521-524. 


\section{CONCLUSÕES}

O trabalho rural de curta duração é atividade que, embora não se inclua entre as inovações provocadas pela globalização e pelos avanços da tecnologia da informação, apresenta-se como desafio ao Direito do Trabalho pátrio. Este, ao mesmo tempo em que discute teletrabalho e procura revisitar o próprio conceito de subordinação jurídica (com a recente alteração do artigo $6^{\circ}$ da CLT para tratar da subordinação exercida por meios telemáticos), de maneira paradoxal, ainda carece de normas aptas a regular de maneira adequada uma antiga relação de trabalho, a dos rurícolas contratados por pequenos períodos.

Ao se olhar no futuro, o Direito do Trabalho eleva a dignidade da pessoa humana como limite a ser imposto ao processo de modernização e flexibilização. Entretanto, ao se olhar no passado e presente, percebe essa mesma dignidade desprotegida diante da rotineira informalidade que notoriamente caracteriza o trabalho rural de curta duração. $\mathrm{O}$ direito ao trabalho digno, previsto em normas internas e internacionais, ainda não favorece os trabalhadores rurais de curtos períodos de forma satisfatória.

Trata-se de dívida histórica. Ao viés urbano e industrial que marcou o início e o desenvolvimento do Direito do Trabalho, somou-se, no Brasil, a estrutura econômica e agrária baseada no latifúndio, com amplo poder econômico e político dos proprietários de terras. Nesse cenário, o país chegou aos dias atuais sem dispor de um modelo jurídico adequado para regular as relações de trabalho rural não duradouras, sendo a informalidade a opção escolhida na maioria dos casos. Nestes, os contratantes se apresentam com a dupla característica de liberdade total de estipulação e desigualdade material manifesta entre as partes, mesmo binômio que, durante a Revolução Industrial, permitiu a exploração extrema do homem pelo homem. Concretiza-se, nessas condições, situação incompatível com o mínimo necessário para a sadia qualidade de vida dos rurícolas, bem-estar físico, psíquico e social, é dizer, subtrai-se do trabalhador o conjunto de direitos básicos e fundamentais condizentes com sua própria dignidade.

O exemplo das cooperativas de mão de obra rural, modelo fracassado, com inúmeras fraudes, demonstra que os sujeitos, na procura por soluções, podem realmente chegar a situações de total negação de direitos fundamentais do trabalhador, sendo imperativo reconhecer que a relação entre trabalho e capital necessita da intervenção 
estatal. Urge, portanto, a criação de um modelo jurídico apto a regular o trabalho rural de curta duração.

O contrato de safra, previsto no parágrafo único do artigo 14 da Lei n. ${ }^{\circ}$ 5.889/73, não se mostra satisfatório ou suficientemente adaptado a tão curtos períodos, de dias ou semanas. As figuras estudadas, trabalho avulso, consórcio de empregadores rurais e contrato por pequeno prazo, identificam-se melhor com os curtos períodos, mas nenhuma consegue se credenciar a regular de maneira ideal tais relações de trabalho. Não obstante, o exame sobre cada uma delas permite algumas reflexões que não devem ser desprezadas no desenvolvimento de alternativas para a formalização do trabalho rural de curta duração.

Dessas três modalidades, a que mais apresenta vantagens é o consórcio de empregadores rurais, por conseguir aliar três características fundamentais: a) reduz, para os produtores, custos e burocracia; b) não suprime direitos trabalhistas, ao contrário, melhora as condições de trabalho, trocando os sucessivos contratos de curtos períodos por uma única relação laboral duradoura; c) está adaptado às peculiaridades do campo, às condições materiais e necessidades dos produtores rurais e trabalhadores.

Assim, o consórcio atesta que o debate não precisa ficar restrito a quais direitos trabalhistas podem ou não ser sacrificados. Destaca-se, assim, o primeiro ponto: é possível reduzir custos e burocracia sem o mínimo afastamento dos direitos trabalhistas.

Para tanto, é necessário buscar novas formas de relação entre empregadores e trabalhadores, novas maneiras de prestação laboral, o que introduz o segundo ponto a ser destacado: o Direito deve considerar novas situações práticas para, a partir delas, cominar consequências jurídicas também novas. Isso porque qualquer norma que preveja consequências jurídicas diversas para situações práticas idênticas violará o princípio da isonomia. A figura do consórcio de empregadores rurais merece elogios porque tratou de contemplar hipótese fática diferente, a união entre os produtores rurais, para estipular consequências jurídicas também diferentes. Ao contrário, a Lei n. ${ }^{\circ}$ 11.718/08, com seu contrato de pequeno prazo, não considerou hipótese fática diversa, simplesmente pretendeu isentar do registro a relação de trabalho empregatícia. Inevitavelmente, maculou o princípio constitucional da isonomia.

A descoberta de novas formas de relacionamento entre trabalhadores e empregadores é algo a que eles próprios podem chegar de maneira mais rápida e adaptada às suas necessidades do que a imposição, pelo Estado, de uma nova forma de trabalho. 
Assim se deu com o consórcio de empregadores rurais, criado a partir da iniciativa dos próprios produtores rurais, com o acompanhamento do Estado, por meio do Ministério Público do Trabalho e Auditoria-Fiscal do Trabalho. Tal acompanhamento se faz necessário para evitar o desvirtuamento de figuras e institutos, como aconteceu com as cooperativas de mão de obra. Desse modo, o terceiro ponto a ser destacado é a vantagem da participação efetiva dos atores sociais envolvidos, acompanhados de perto pelo Estado.

A postura ativa dos sujeitos que conhecem e vivenciam as peculiaridades do meio rural traz mais um ponto a ser ressaltado: necessidade de se observarem as condições materiais do campo, suas peculiaridades. O trabalho avulso, tão desenvolvido na orla marítima, ou as cooperativas, valorosas quando legítimas, precisariam vencer grandes obstáculos de ordem prática para se adaptarem às condições do campo.

Entre essas condições estão, infelizmente, as precárias circunstâncias econômicas, sociais e culturais em que vive a maioria dos trabalhadores rurais. Merece destaque, assim, a consciência de que a mera previsão normativa de um modelo jurídico, adequado ao trabalho rural de curta duração, seguramente não será a solução para as precárias condições de vida dos trabalhadores rurais. Entretanto, isso não é motivo para que o Direito permaneça em falta, permaneça sem ofertar alternativa cabível para que, ao menos nas relações de trabalho, o rurícola possa desfrutar de proteção à sua dignidade.

Da mesma maneira que um modelo jurídico de contratação não será capaz de resolver a miserabilidade dos "boias-frias", também não será capaz de permanecer imune a fraudes e distorções. Entretanto, a possibilidade de fraude não é exceção no Direito do Trabalho e não deve levar ao abandono de determinada figura jurídica. O contrato por pequeno prazo, o trabalho avulso e o consórcio de empregadores rurais são passíveis de fraude. O que é necessário é distinguir entre a figura jurídica que apresenta, ela própria, inconstitucionalidades, como o contrato por pequeno prazo, e a que, apesar de sua validade, pode ser desvirtuada.

Nesse contexto, ganha importância a intervenção do Estado e de suas instituições responsáveis por zelar pelo cumprimento das normas trabalhistas, Justiça do Trabalho, Ministério Público do Trabalho e Auditoria-Fiscal do Trabalho, na tarefa de coibir ilicitudes, punir exemplarmente os fraudadores e, não obstante, orientar aqueles que, apesar de estarem dispostos à regularização, carecem de informações. Valoriza-se também, por óbvio, a necessidade de se prover o meio rural de escolas de qualidade e acessíveis, para que o homem do campo possa, alfabetizado, ser consciente de seus próprios direitos. 
Após destacar os pontos acima, cabe observar, como pano de fundo dos altos índices de informalidade do trabalho rural de curta duração, a fragilidade econômica dos pequenos produtores rurais. Tome-se o exemplo do consórcio de empregadores rurais que, apesar de ostentar vantagens, tem sua expansão tolhida pela vulnerabilidade de sua raiz, fundada na necessária confiança entre os participantes. A figura jurídica concentra na responsabilidade solidária dos consorciados a garantia da satisfação dos direitos dos trabalhadores, sem se preocupar em garantir, por outro lado, a segurança necessária para a atividade econômica de cada produtor rural. Estes, por vezes, são apenas mais um elo na corrente produtiva sob o comando econômico da agroindústria, com esta relacionando-se em posição de desvantagem econômica.

Outro ponto a se destacar, portanto: qualquer modelo jurídico que pretenda preservar os direitos dos trabalhadores rurais não terá êxito se não olhar, também, para as condições de sobrevivência econômica dos pequenos produtores rurais, fonte dos postos de trabalho.

Nesse sentido, os modelos estudados apontam dois caminhos: a) o contrato por pequeno prazo propõe diminuição de custos através da redução de direitos trabalhistas, marcando-se pela inconstitucionalidade; b) o consórcio de empregadores rurais e o trabalho avulso possibilitam a redução de custos por meio da participação de mais um personagem gerenciando a mão de obra, o sindicato intermediador ou o OGMO rural, no trabalho avulso, e o ente coletivo formado pela união dos produtores, no consórcio.

Especialmente no consórcio de empregadores rurais, a introdução de mais um personagem na relação laboral provoca a diminuição de custos não a partir da redução de direitos trabalhistas, mas através de circunstâncias somente obtidas em função da administração centralizada da mão de obra a ser utilizada por diversos produtores rurais, como: aquisição em grandes lotes, portanto a preços mais acessíveis, de ferramentas e equipamentos de proteção; melhores condições de negociação com empresas especializadas em segurança e saúde; administração única do transporte dos diversos trabalhadores; contrato de trabalho único e prolongado, evitando-se os custos e a burocracia de seguidas dispensas e recontratações; possibilidade, a partir da maior duração da relação entre trabalhador empregador, de treinamento e conseqüente aumento da produtividade, entre outras. 
Esse novo personagem, ao administrar as atividades dos trabalhadores não age como intermediador, que busca lucro com o fornecimento de mão de obra. Trata-se de característica importante, pois a inclusão na relação laboral de um terceiro, que busque lucros com a intermediação, significa aumentar os riscos de violação dos direitos trabalhistas, pois é mais um elo na corrente produtiva, mais um personagem a pretender maximizar a diferença entre receita e custo.

No meio rural, a ausência de legislação específica sobre terceirização, prevendo direitos e deveres, garantias e responsabilidades, potencializa a possibilidade de afronta aos direitos trabalhistas, o que se percebe com as costumeiras intermediações ilícitas, engendradas pelos chamados "turmeiros" ou "gatos". Assim, a hipótese de administração centralizada de mão de obra, ao ser cogitada por intermédio da terceirização, não supera obstáculos como a falta de legislação disciplinando a matéria e o problema cultural da exploração dos rurícolas por intermediação em condições precárias.

Buscando ainda alternativas, é inevitável a reflexão a respeito de outro personagem que consegue, centralizando a administração da mão de obra, agregar aquelas mesmas circunstâncias que permitem a redução de custos sem ofender direitos trabalhistas. Trata-se da situação em que se faz presente o grande poder econômico da agroindústria, com a possibilidade de contratação direta dos trabalhadores rurais. Ao contrário de se inserir mais um elo na corrente produtiva, a buscar lucro e redução de custos, bastaria que a agroindústria, ao adquirir produtos rurais de pequenos produtores, se responsabilizasse pelas tarefas rurais de curta duração. Ainda que os custos trabalhistas fossem divididos com os fornecedores, embutidos no preço dos produtos, a alternativa indica melhoria das condições de trabalho dos rurícolas.

Tal situação já se fez presente na década de 1980, com a indústria paulista de suco de laranja assumindo o papel de personagem com capacidade financeira suficiente para arcar com os custos trabalhistas. Sem dúvida, a contratação direta pela agroindústria permite, da mesma forma que o consórcio de empregadores rurais, a racionalização da administração da mão de obra, com custos mais reduzidos se comparados aos da contratação individual de cada produtor rural. Seria possível, assim, reduzir custos sem reduzir direitos.

Essa alternativa concilia a liberdade de iniciativa com a valorização do trabalho, dois fundamentos da República Brasileira (art. $1^{\circ}$, inciso IV da Constituição da República). Por óbvio, quanto maior o poderio econômico do empregador, maior será sua capacidade de respeitar os direitos básicos dos trabalhadores contratados, vislumbrando-se a possível 
melhoria das condições de dignidade dos rurícolas, sem a necessidade de novos modelos contratuais. Entretanto, essa alternativa se limita aos casos em que a agroindústria se apresenta como adquirente dos produtos agrícolas. Ademais, como visto, já na década de 1990 as indústrias fizeram movimento na direção oposta, evitando a contratação direta dos trabalhadores rurais.

Em resumo, conclui-se que o Direito do Trabalho pátrio ainda não se apresenta apto a garantir o respeito à dignidade dos trabalhadores rurais nas relações de trabalho de curta duração, pois não dispõe de modelo jurídico suficientemente adaptado às peculiaridades desse tipo de relação. Deixa, assim, de atender aos comandos constitucionais de preservação da dignidade da pessoa humana e valorização do trabalho. O Direito do Trabalho deve observar as experiências já empreendidas e avançar para afirmar e, mais que isso, concretizar a incontestável verdade: o trabalhador rural de curtos períodos, o "boiafria", merece, tanto quanto os demais trabalhadores, tutela do Direito do Trabalho, pois, como eles, é sujeito de Direitos Fundamentais e, possui, pelo simples fato de existir, dignidade a ser preservada pelo ordenamento jurídico. 


\section{REFERÊNCIAS BIBLIOGRÁFICAS}

AHMED, Iftikhar. El trabajo decente y el desarollo humano. Revista Internacional del Trabajo. Ginebra, v. 122, n. 2, p. 291-299, 2003.

ALMEIDA, Paulo Guilherme de. Aspectos negativos da legislação trabalhista rural. LTr: suplemento trabalhista, São Paulo, ano 13, n. 87, p. 393-396, 1987.

ALONSO OLEA, Manuel; CASAS BAAMONDE, Maria Emilia. Derecho del trabajo. 18. ed. Madrid: Civitas, 2000.

ALVARENGA, Rúbia Zanotelli de. Consórcio de empregadores rurais: viabilidade jurídico-econômica para trabalhadores e produtores rurais. O Trabalho, Curitiba, n. 94, p. 2470-2480, dez. 2004.

ALVES, Francisco José da Costa et al. A flexibilização dos direitos trabalhistas chega ao campo: o caso do setor citrícola - o ouro que virou suco. Revista LTr, São Paulo, ano 60, n. 2, p. 220-227, fev. 1996.

; PAULILLO, Luiz Fernando. Sindicato dos trabalhadores avulsos: a agricultura paulista sai na frente. Revista LTr, São Paulo, ano 63, n. 8. p. 1048-1055. ago. 1999.

ANDRADE, Dárcio Guimarães de. I - A ação civil pública e o FGTS II - Condomínio de empregadores. LTr: suplemento trabalhista, São Paulo, v. 37, n. 58, p. 283-286, 2001.

Condomínio de empregadores. Revista do Tribunal Regional do Trabalho da $8^{a}$ Região, Belém, v. 34, n. 66, p. 57-60, jan./jun. 2001.

ANDRADE JÚNIOR, Roque Jurandy. Efeitos da isonomia jurídica entre os trabalhadores portuários avulsos e os com vínculo de emprego na duração do trabalho. LTr: suplemento trabalhista, São Paulo, v. 43, n. 31, p. 143-148, 2007.

ARAÚJO, José Carlos Evangelista de. Modernização e conflito: os dilemas colocados pela questão agrária no Brasil. In: GIORDANI, Francisco Alberto da Motta Peixoto; MARTINS, Melchíades Rodrigues; VIDOTTI, Tarcio José (Coords.). Direito do trabalho rural: homenagem a Irany Ferrari. 2. ed. São Paulo: LTr, 2005. p. 23-64.

BARROS, Alice Monteiro de. Aspectos controvertidos do trabalho rural. Trabalho $e$ Doutrina: processo jurisprudência, São Paulo, n. 8, p. 27-49, mar. 1996.

Contratos e regulamentações especiais de trabalho: peculiaridades, aspectos controvertidos e tendências. São Paulo: LTr, 2001.

Curso de direito do trabalho. 7. ed. São Paulo: LTr, 2011. 
BARROS, Alice Monteiro de. Flexibilização e garantias mínimas. Trabalho e Doutrina: processo jurisprudência, São Paulo, n. 20, p. 9-20, mar. 1999.

Terceirização no direito do trabalho. Revista do Instituto Goiano de Direito do Trabalho, Goiânia, v. 1, n.1, p. 23-30, nov. 1993.

BELTRAN, Ari Possidônio. Dilemas do trabalho e do emprego na atualidade. São Paulo: LTr, 2001.

Direito do trabalho e direitos fundamentais. São Paulo: LTr. 2002.

BIGNAMI, Renato. A inspeção do trabalho no Brasil: procedimentos especiais para a ação fiscal. São Paulo: LTr, 2007.

BIRRER, Orlando Izaque. Conquistas, problemas e perspectivas do sindicalismo rural dos trabalhadores. Revista do Tribunal Regional do Trabalho da 15 . Região, Campinas, $\mathrm{n}$. esp. p. 43-48, 1995.

BOUCINHAS FILHO, Jorge Cavalcanti. Intervalos Intrajornada para o trabalho rural em exposição ao calor excessivo. Revista Síntese Trabalhista e Previdenciária, Brasília, v 23, n. 265, p. 70-85, jul. 2011.

BRAGA, Jose dos Santos Pereira. Aspectos peculiares do trabalho rural: intermitência da prestação, conceito de jornada de trabalho e tempo à disposição do empregador. Revista do Instituto Goiano de Direito do Trabalho, Goiânia, v. 2, n. 3, p. 134-145, 1994.

BREBBIA, Fernando P. Il lavoro dipendente in agricoltura. Rivista di Diritto Agrario, Milano, v. 71, n. 3, p. 427-436, lug./sett. 1992.

BRITO FILHO, José Claudio Monteiro de. Trabalho decente. Revista do Tribunal Regional do Trabalho da $8^{a}$ Região, Belém, v. 37, n. 73, p. 97-106, jul./dez. 2004.

BUEN, Néstor de. La Organizacion Internacional del Trabajo (OIT) y el trabajo rural. Revista do Tribunal Regional do Trabalho da $15^{a}$ Região, Campinas, n. esp. p. 78-88, 1995.

CAMPOS, Marcelo Gonçalves. Relações de trabalho rural e ilegalidade nas contratações: uma busca de soluções. Síntese Trabalhista, Porto Alegre, v. 12, n. 138, p. 5-18, dez. 2000.

CASSAR, Vólia Bonfim. A globalização e a crise do direito do trabalho: limite à flexibilização. Revista Magister de Direito Trabalhista e Previdenciário, Porto Alegre, v. 3, n. 16, p. 14-41, jan./fev. 2007.

CATHARINO, José Martins. Compêndio universitário de direito do trabalho. São Paulo: Editora Jurídica e Universitária, 1972. v. 1 e 2. 
CESARINO JUNIOR, Antonio Ferreira. Direito social brasileiro. 6. ed. São Paulo: Saraiva, 1970. v. 2.

CHEBABI, Marilda Izique. Direito do trabalho rural. Revista do TRT da $15^{a}$ Região, n. 10, p. 195-207, 2000.

COMPARATO, Fábio Konder. A afirmação histórica dos direitos humanos. São Paulo: Saraiva, 1999.

COSTA E SILVA, Kataryna Just da. Consórcio de empregadores rurais: uma alternativa de contratação no meio rural na busca da dignidade do homem do campo. Revista do Tribunal Regional do Trabalho da $6^{a}$ Região, ano 1, n. 1, p. 120-127, 2001.

CUÓCO, Ubiracy Torres. Trabalhadores avulsos. Revista LTr, São Paulo, ano 70, n. 4. p. 475-483, abr. 2006.

DAMIANO, Henrique. Cooperativas de trabalho e consórcio de empregadores rurais. Revista do Tribunal Regional do Trabalho da $15^{a}$ Região, Campinas, n. 19, p. 175-196, jun. 2002.

DE MATIA, Fábio Maria. Empresa agrária e estabelecimento agrário. Revista Trimestral de Jurisprudência dos Estados, São Paulo, v. 19, n. 135, p. 33-60, abr. 1995.

DELGADO, Gabriela Neves. Direito fundamental ao trabalho digno. São Paulo: LTr, 2006.

O trabalho enquanto suporte de valor. Revista da Faculdade de Direito da Universidade Federal de Minas Gerais, Belo Horizonte, n. 49, p. 77-97, jul./dez. 2006.

; MIRAGLIA, Lívia Mendes Moreira. A tendência expansionista do Direito do trabalho: breve análise a partir do fundamento de proteção ao trabalho previsto na Constituição Federal de 1988. Revista Síntese Trabalhista e Previdenciária, Brasília, v. 22, n. 263, p. 87-107, maio 2011.

DELGADO, Mauricio Godinho. Curso de direito do trabalho. 5. ed. São Paulo: LTr. 2006. Princípios do direito do trabalho. Revista LTr, São Paulo, v. 59, n. 4, p. 472-482, abr. 1995.

DI TURI, Claúdio. Globalizzazione dell'economia e diritti fondamentali in materia di lavoro. Rivista di Diritto Internazionale, Milano, v. 83, n. 1, p. 113-131, 2000.

DINIZ, Maria Helena. Dicionário jurídico. São Paulo: Saraiva, 1998. v. 3.

EGGER, Philippe. Las organizaciones de trabajadores rurales y las condiciones de trabajo em la agricultura. Educacion Obrera, Ginebra, v.98, n. 1, p.4-8, 1995. 
ERMIDA URIARTE, Oscar. Crisis y derecho deI trabajo: viejos conocidos. Revista de la Facultad de Derecho, Montevideo, n. 27, p. 81-87, 2008/2009.

FARIA, José Eduardo Campos de Oliveira. A crise do direito do trabalho no Brasil. Revista da Faculdade de Direito da Universidade de São Paulo, São Paulo, v. 80, p. 197209, jan./dez. 1985.

FERRARI, Irany. Contratação de trabalhador rural por pequeno prazo para atividades de natureza temporárias. LTr: suplemento trabalhista, São Paulo, v. 44, n. 14, p. 72, 2008.

Cooperativas de trabalho: existência legal. 2. ed. São Paulo: LTr. 2002.

- Uma alternativa para a contratação de mão-de-obra rural: consórcio de empregadores no meio rural. LTr: suplemento trabalhista, São Paulo, v. 35, n. 148, p. 785$787,1999$.

FERREIRA, José Otávio de Souza. Relação de emprego rural. In: GIORDANI, Francisco Alberto da Motta Peixoto; MARTINS, Melchíades Rodrigues; VIDOTTI, Tarcio José (Coords.). Direito do trabalho rural: homenagem a Irany Ferrari. 2. ed. São Paulo. LTr, 2005.

FIELDS, Gary S. El trabalho decente y las políticas de desarrollo. Revista Internacional del Trabajo, Ginebra, v. 122, n. 2, p. 263-290, 2003.

FONSECA, Ricardo Tadeu Marques da. Consórcio de empregadores: uma alternativa imediata para a empregabilidade. Revista do Ministério Público do Trabalho, Brasília, v. 10, n. 19, p. 79-89, mar. 2000.

Modalidades de contratação no meio rural e o consórcio de empregadores. $L T r$ : suplemento trabalhista. São Paulo, v. 37, n. 17, p. 95-100, 2001.

FONTANA, Antonio. Aspetti giuridici del lavoro stagionale in agricoltura. Il Diritto del Lavoro, Roma, n. 6, p. 867-896, nov./dic. 1998.

. La disciplina del lavopro agricolo in Italia. Rivista di Diritto Agrario, Milano, v. 71, n. 3, p. 437-449, lug./sett. 1992.

FORASTIERI, Valentina. Programa de la OIT sobre seguridad y salud en la agricultura: el reto para el siglo XXI; proporcionar servicios de seguridad y salud en el trabajo a los trabajadores del agro. Educación Obrera, Ginebra, n. 118/119, p. 1-18. 2000.

FRANÇA, Milton de Moura. Abrangência do Direito do Trabalho Rural: emprego, parceria e arrendamento. Revista do Tribunal Regional do Trabalho da $9^{a}$. Região, Curitiba, v. 19, n. 1, p. 97-105, jan./dez. 1994. 
FREDIANI, Yone (Coord). Tendências do direito material e processual do trabalho. São Paulo: LTr, 2000.

FREITAS JUNIOR, Antonio Rodrigues. Outro século de corporativismo sindical no Brasil? Revista de Direito do Trabalho, São Paulo, v. 26, n. 100, p. 59-66, out./dez. 2000.

(Org.). Direito do trabalho e direitos humanos. São Paulo: BH. 2006.

FURTADO, Raquel Pereira. A lei do trabalho rural e a medida provisória n. ${ }^{\circ} 410$. Justiça $^{2}$ do Trabalho, Porto Alegre, v. 25, n. 296, p. 79-82, ago. 2008.

GALDINO, Dirceu. Uma forma vantajosa de registrar empregados sem intermediação. Revista LTr, São Paulo, ano 62, n. 2, p. 184-190, fev. 1998.

; LOPES, Aparecido Domingos Errerias. Manual do direito do trabalho rural. 3. ed. rev. atual. São Paulo: LTr. 1995.

GARCIA, Gustavo Filipe Barbosa. Contrato de trabalho rural por pequeno prazo e precarização das relações de trabalho no campo. LTr: suplemento trabalhista, São Paulo n. 108, p. 509-512, 2009.

Curso de direito do trabalho. 5. ed. rev. atual. ampl. Rio de Janeiro: Forense, 2011.

Trabalho análogo à condição de escravo e degradante: antítese do trabalho decente. Justiça do Trabalho, Porto Alegre, v. 25, n. 290, p. 24-30, fev. 2008.

GATTA, Carlo. La specificitá del lavoro nelle piccole aziende agricole e le norme di sicurezza. Il Diritto del Lavoro, Roma, n. 6, p. 813-816, nov./dic. 1998.

GHAI, Dharam. Trabajo decente: concepto e indicadores. Revista Internacional del Trabajo, Ginebra, v. 122, n. 2, p. 125-160, 2003.

GIORDANI, Francisco Alberto Motta Peixoto. Alguns aspectos da segurança e medicina do trabalho no meio rural. LTr: suplemento trabalhista, São Paulo, v. 34, n. 124, p. $567-$ $569,1998$.

Intermediação de mão de obra: uma leitura que leva à reponsabilidade solidária entre as empresas prestadora e tomadora de serviços. Revista do Tribunal Regional do Trabalho da 15ª Região, Campinas, n. 32, p. 67-78, jan./jun. 2008.

; VIDOTTI, Tarcio José; MARTINS, Melchíades Rodrigues (Coords). Direito do trabalho rural: homenagem a Irany Ferrari. 2. ed. São Paulo: LTr. 2005.

GOMES, Claudio Urenha. Flexibilização e trabalho rural (cooperativas). LTr: suplemento trabalhista, São Paulo, v. 36, n. 20, p. 97-100, 2000. 
GOMES, Claudio Urenha. Trabalho rural: a permissão da terceirização em atividade-fim. Revista LTr, São Paulo, v. 69, n. 11, p. 1375-1378, nov. 2005.

GOMES, Orlando; GOTTSCHALK, Elson. Curso de direito do trabalho. 14. ed. Rio de Janeiro: Forense, 1995.

HOUAISS, Antonio. VILLAR, Mauro de Salles. Minidicionário Houaiss da língua portuguesa. 2. ed. Rio de Janeiro: Objetiva, 2004.

IGLESIAS, Gerardo; CELIBERTI, Ariel. Trabajadores rurales de América Latina: entre la exclusión y la construccion de alternativas. Educación Obrera, Ginebra, v. 2/3, n. 131/132, p. 17-22, 2003.

IZIQUE, Marilda. Direito do Trabalho Rural. Revista do Tribunal Regional do Trabalho da 15a Região, Campinas, n. 10, p. 195-207, jan./mar. 2000.

JACQUIER, Christian. La protección social em la agricultura. Educación Obrera, Ginebra, v. 2/3, n. 131/132, p. 35-40, 2003.

JUCÁ, Francisco Pedro. A constitucionalização dos direitos dos trabalhadores $e$ a hermenêutica das normas infraconstitucionais. São Paulo: LTr, 1997.

Disciplinamento do trabalho rural. In: CONGRESSO BRASILEIRO DE DIREITO DO TRABALHO, 4. 25-27 mar. 1996. Jornal do Congresso. São Paulo, LTr, 1996. p. 43-44.

Renovação do direito do trabalho: abordagem alternativa à flexibilização. São Paulo: LTr. 2000.

LARANJEIRA, Raymundo. Trabalho rural e estrutura agrária no Brasil. Revista LTr, São Paulo, ano 47, n. 3, p. 303-311, mar. 1983.

LEITE, Carlos Henrique Bezerra. Cooperativismo: enfoques trabalhistas. Trabalho $e$ Doutrina: processo jurisprudência, São Paulo, n. 17, p. 45-56. 1998.

LEMES, Viviane Aparecida. A figura jurídica do consórcio de empregadores rurais: reflexões teóricas a partir de exemplos práticos. São Paulo: LTr, 2004.

Legislação trabalhista rural no mundo globalizado: contradições e perspectivas. Revista do Tribunal Regional do Trabalho da $15^{a}$ Região, Campinas, n. 25, p. 268-279, 2004.

LIMA, Rusinete Dantas de. Aspectos teóricos e práticos da terceirização do trabalho rural: cooperativas de trabalho rural. São Paulo: LTr, 1999. 
LIMA, Rusinete Dantas de. O trabalho rural no Brasil. São Paulo: LTr, 1992.

MAGANO, Octávio Bueno. Cooperativas. Revista de Direito do Trabalho, São Paulo, v. 25, n. 95, p. 43-47, jul./set. 1996.

. Flexibilização constitucional. Revista do Tribunal Regional do Trabalho da $9^{a}$.

Região, Curitiba, v. 21, n. 1, p. 55-57, jan./jul. 1996.

. Manual de direito do trabalho. 2. ed. São Paulo: LTr. 1984. v. 2.

. Manual de direito do trabalho: direito individual do trabalho. 3. ed. São Paulo:

LTr. 1993. v. 2.

Princípios para uma reforma da legislação trabalhista. Cadernos de Direito Constitucional e Ciência Política, São Paulo, v. 2, n. 8, p. 101-102, jul./set. 1994.

MANIGLIA, Elisabete. Mulheres na agricultura. Revista de Estudos Jurídicos UNESP, Franca, v. 5, n. 3, p. 201-210, jan./jul. 1998.

- O trabalho rural e a função social da propriedade. Revista de Estudos Jurídicos UNESP, Franca, v. 5, n. 9, p. 67-74, jan./dez. 2000.

MANNRICH, Nelson. Alternativas para o trabalho rural. Revista IMES - Direito: revista do Curso de Direito do Centro Universitário Municipal de São Caetano do Sul, São Caetano do Sul, v. 1, n. 2, p. 31-40, jan./jun. 2001.

. Consórcio de empregadores rurais. $I O B$ : repertório de jurisprudência: trabalhista e previdenciário, São Paulo, n. 20, p. 396-394, out. 2000.

. Flexibilização do direito do trabalho: ruptura e compromisso. Revista de Estudos Jurídicos UNESP, Franca, v. 3, n. 6, p. 205-207, 1998.

Inderrogabilidade da norma trabalhista e indisponibilidade de direitos: algumas reflexões. Revista da Academia Nacional de Direito do Trabalho, São Paulo, v. 17, n. 17, p. 78-84, 2009.

Inspeção do trabalho. São Paulo: LTr, 1991.

Limites da flexibilização das normas trabalhistas. Revista do Advogado, São Paulo, n. 54, p. 29-36, dez. 1998.

Modelos de relações trabalhistas: reflexão sobre propostas de reforma. O negociado e o legislado. Revista de Direito do Trabalho, São Paulo, n. 101, p. 71-83, jan./mar. 2001. 
MANNRICH, Nelson. A modernização do contrato de trabalho. São Paulo: LTr. 1998.

MANTARAS, Luis Manuel. Las particularidades del trabajo agrario. Revista Argentina de Derecho Agrario y Comparado, Rosario, v. 2, n. 3, p. 77-88, dic. 1993.

MARTINS, Sergio Pinto. Consórcio de empregadores rurais. Orientador Trabalhista: suplemento de legislação, jurisprudência e doutrina, São Paulo, v. 19, n. 4, p. 5-8, abr. 2000.

Contribuição previdenciária do produtor rural pessoa física e do segurado especial. $I O B$ : repertório de jurisprudência: tributário, constitucional e administrativo, São Paulo, n. 21, p. 487-485, nov. 1996.

- Contribuição sindical patronal rural. Orientador Trabalhista: suplemento de legislação, jurisprudência e doutrina, São Paulo, v. 22, n. 9, p. 3-12, set. 2003.

Custo do trabalho e desemprego. Trabalho e Doutrina: processo jurisprudência, São Paulo, n. 23, p. 35-43, dez. 1999.

A economia informal e o direito do trabalho. Revista do Tribunal Regional do Trabalho da 8ª Região, Belém, v. 29, n. 57, p. 95-109, jul./dez. 1996.

. Direito da seguridade social. 19. ed. São Paulo. Atlas 2003.

. Direito do trabalho. 27. ed. São Paulo: Atlas, 2011.

. Flexibilização das condições de trabalho. 4. ed. São Paulo: Atlas, 2009.

- A flexibilização e os princípios do direito do trabalho. Trabalho e Doutrina: processo jurisprudência, São Paulo, n. 27, p. 16-18, dez. 2002.

- Relações entre o direito do trabalho e o direito civil. Trabalho e Doutrina: processo jurisprudência, São Paulo, n. 12, p. 123-132, mar. 1997.

- Terceirização lícita e ilícita. IOB: repertório de jurisprudência: trabalhista e previdenciário, São Paulo, n. 8, p. 158-155, abr. 1997.

MAZUR, Maurício. Consórcio de empregadores rurais: a mais nova forma de contratação de trabalho rural. Curitiba: Juruá, 2003.

MELO, Raimundo Simão de. Cooperativas de trabalho. Revista de Direito do Trabalho, São Paulo, v. 25, n. 95, p. 48-53, jul./set. 1996.

Dignidade da pessoa humana e meio ambiente de trabalho. Revista de Direito do Trabalho, São Paulo, v. 31, n. 117, p. 204-220, jan./mar. 2005.

Direito ambiental do trabalho e a saúde do trabalhador. 3. ed. São Paulo: LTr, 2008. 
MELO, Raimundo Simão de. Flexibilização dos direitos trabalhistas e as cooperativas de trabalho. Revista do Ministério Público do Trabalho, Brasília, v. 8, n. 15, p. 64-74, 1998.

MENDONÇA, Maria Luisa. Morte e violação de direitos nas usinas de etanol em São Paulo. ALAI, América Latina en Movimiento, 21 set. 2007. Disponível em: $<$ http://alainet.org/active/19784\&lang=es>.

MINISTÉRIO DO TRABALHO E EMRPEGO. Manual de orientação do CAGED. Cadastro geral de empregados e desempregados. Lei n. 4923/65. Brasília, DF, 2010. Disponível em: <http://www.caged.gov.br/downloads/caged/Manual_CAGED_2010_versaoACI10-1.pdf>. . Manual da RAIS. Disponível em: <http://portal.mte.gov.br/rais/manual-da-rais2010.htm>.

MONTANHANA, Beatriz. A constitucionalização dos direitos sociais: a afirmação da dignidade do trabalhador. In: FREITAS JR., Antonio Rodrigues (Org.). Direito do trabalho e direitos humanos. São Paulo: BH Ed., 2006.

MONTEIRO, Washington de Barros. Curso de direito civil: direito das obrigações. São Paulo: Saraiva. 1956. v. 2.

MORAES FILHO, Evaristo. Conceito de trabalhador rural e enquadramento sindical: estudos de direito do trabalho. São Paulo: LTr, 1971.

NAHAS, Thereza Cristina. Inovações na lei do trabalho rural. LTr: suplemento trabalhista, São Paulo, v. 37, n. 7, p. 35-38, 2001.

NASCIMENTO, Amauri Mascaro. O avulso não portuário e a intermediação do sindicato. LTr: revista legislação do trabalho, São Paulo, v. 68, n. 2, p. 135-145, fev. 2004.

O avulso não-portuário e o trabalho rural. In: GIORDANI, Francisco Alberto da Motta Peixoto; MARTINS, Melchíades Rodrigues; VIDOTTI, Tarcio José (Coords.). Direito do trabalho rural: homenagem a Irany Ferrari. 2. ed. São Paulo. LTr, 2005.

. Curso de direito do trabalho. 24. ed. rev. atual. e ampl. São Paulo: Saraiva. 2009.

. Curso de direito do trabalho. 26. ed. São Paulo: Saraiva, 2011.

Globalização e seus efeitos no contrato de trabalho. In: FREDIANI, Yone (Coord). Tendências do direito material e processual do trabalho. São Paulo: LTr, 2000.

Movimentadores de mercadoria como categoria diferenciada: a análise da movimentação de cargas e mercadorias. Disponível em: http://www.nucleomascaro.com.br/blog/?p=18>. Acesso em: 25 nov. 2011. 
NASCIMENTO, Amauri Mascaro. O novo conceito de trabalhador avulso. Trabalho $e$ Doutrina: processo jurisprudência, São Paulo, n. 19, p. 3-12, dez. 1998.

. Princípios do direito do trabalho e direitos fundamentais do trabalhador. $L T r$ : revista legislação do trabalho, São Paulo, v. 67, n. 8, p. 903-916, ago. 2003.

O trabalho rural na Constituição de 1988: regulamentação e realidade. Revista LTr, São Paulo, ano 59, n. 10, p. 1305-1310, out. 1995.

. Subcontratação ou terceirização. Revista de Direito do Trabalho, São Paulo, n. 83, p. 20-25, set. 1993.

. Visão global do direito do trabalho rural no Brasil. Revista do Tribunal Regional do Trabalho da 15ª Região, n. esp., p. 58-64, 1995.

OLIVEIRA, Murilo. Crise do direito do trabalho. LTr: revista legislação do trabalho, São Paulo, v. 70, n. 8, p. 998-1007, ago. 2006.

PACHECO, Iara Alves Cordeiro. Cooperativas de trabalho x intermediação de mão-deobra. Revista do TRT da 15a Região, Campinas, n. 8, p. 75-86, 1996.

PALMEIRA SOBRINHO, Zéu. O novo contrato de trabalho rural por pequeno prazo. Trabalho em Revista Nacional, v. 26, n. 306, p. 13-14, jan. 2008.

PATEL, Meena. Empleo rural: un reto creciente para el movimiento sindical. Educacion Obrera, Ginebra, v. 98, n. 1, p. 34-39. 1994.

PEDREIRA, Pinho. O direito do trabalho na crise. Revista do Tribunal Regional do Trabalho da $8^{a}$ Região, Belém, v. 21, n. 40, p. 73-97, jan./jun. 1988.

PELEGRINI, Mari Ângela. Trabalhadores sem vínculo rurais e urbanos: do cais ao campo. São Paulo: LTr, 2004.

PELEGRINO, Antenor. Trabalho rural: orientações práticas ao empregador. 3. ed. rev., atual. e ampl. São Paulo: LTr, 1988.

PEREIRA, Caio Mario da Silva. Instituições de direito civil: contratos. 15. ed. Rio de Janeiro: Forense, 2011. v. 3.

PIRES, Aurélio. Aspectos teóricos e práticos sobre trabalho rural. 5. ed. rev. atual. São Paulo: LTr, 1996.

Consórcio de empregadores rurais. Revista LTr, São Paulo, ano 65, n. 10, p. 12091211, out. 2001.

PLÁ RODRIGUEZ, Américo. Princípios de direito do trabalho. Trad. Wagner Giglio. 3. ed. atual. São Paulo: LTr, 2000. 
PRADO, Roberto Barretto. Comentários a nova lei do trabalho rural: comentários a Lei $\mathrm{n}$. 5.889, de 8 de junho de 1973. São Paulo: Ed. Revista dos Tribunais, 1975.

PRATA, Marcelo Rodrigues. Inovações quanto ao contrato do trabalhador rural. Revista LTr, São Paulo, ano 61, n. 2, p. 171-174, fev. 1997.

PRESIDÊNCIA DA REPÚBLICA FEDERATIVA DO BRASIL. EMI 00040 MF - MPS TEM. Disponível em: <http://www.planalto.gov.br/ccivil_03/_Ato20072010/2007/Exm/EMI-40-MF-MPS-MTE.htm>. Acesso em: 31 out. 2011.

QUEIROZ, Carlos Alberto Ramos Soares de. Consórcio de empregadores: uma alternativa de risco. RDT: revista do direito trabalhista, v. 6, n. 2, p. 12-13, fev. 2000.

REZENDE, Nilza Perez de. Obrigações trabalhistas do empregador rural. 4. ed. rev. atual. São Paulo: LTr. 1982.

ROMITA, Arion Sayão. A reforma (?) trabalhista. Revista LTr, São Paulo, ano 66, n. 4, p. 395-401, abr. 2002.

RÜDIGER, Dorothêe Susanne. Da gambiarra à conexão em rede: problemas teóricos jurídicos do consórcio de empregadores rurais como empregador único. In: GIORDANI, Francisco Alberto da Motta Peixoto; MARTINS, Melchíades Rodrigues; VIDOTTI, Tarcio José (Coords.). Direito do trabalho rural: homenagem a Irany Ferrari. 2. ed. São Paulo. LTr, 2005. p. 86-98.

RUSSOMANO, Mozart Victor. Comentários ao Estatuto do Trabalhador Rural. 2. ed. São Paulo: Ed. Revista dos Tribunais. 1969. v. 1.

SALVADOR, Luiz. Trabalho decente na economia solidária a busca da inclusão social pela dignidade humana. LTr: suplemento trabalhista, São Paulo, v. 40, n. 89, p. 391-395, 2004.

SAMPAIO, Aluysio. Contrato de trabalho rural. São Paulo: Ed. Revista dos Tribunais, 1974.

Dicionário de direito do trabalho rural. São Paulo: LTr. 1975.

SANDIN, Fábio Lucas Telles de Menezes A. O bloco de constitucionalidade e os direitos humanos nas relações de trabalho. LTr: suplemento trabalhista, São Paulo, v. 45, n. 32, p. 159-166, 2009.

SANTOS, Enoque Ribeiro dos. A função social do contrato e o direito do trabalho. LTr: revista legislação do trabalho, São Paulo, v. 67, n. 12, p. 1460-1468, dez. 2003.

SANTOS, Felipe Antonio Lopes. Trabalho decente e a concretização do direito do trabalho - aspectos relevantes. $L T r$ : revista legislação do trabalho, São Paulo, v. 74, n. 2, p. 225 232, fev. 2010. 
SANTOS, Ronaldo Lima dos. Dignidade humana da criança e do adolescente e as relações de trabalho. In: FREITAS JR., Antonio Rodrigues (Org.) Direito do trabalho e direitos humanos. São Paulo: BH Ed., 2006.

Sindicatos e ações coletivas: acesso à justiça coletiva e tutela dos interesses difusos, coletivos e individuais homogêneos. 2. ed. São Paulo: LTr, 2008.

SANTOS, Saulo Emidio dos. Direito do trabalho rural. Revista LTr, São Paulo, v. 51, n. 4, p. 400-406, abr. 1987.

SANTOS, Ulisses Otávio Elias dos. Considerações sobre o contrato de pequeno prazo no trabalho rural. Revista Bonijuris, Curitiba, v. 20, n. 538, set. 2008.

SARLET, Ingo Wolfgang. Dignidade da pessoa humana e direitos fundamentais na Constituição Federal de 1988. 9. ed. Porto Alegre: Livraria do Advogado, 2011.

SENA, Natália; OLIVEIRA, Andressa Batista de. Contrato de trabalho rural por pequeno prazo - Lei n.11.718/08 - um convite à fraude. LTr: suplemento trabalhista, São Paulo, ano, 44, n. 105, p. 521-524, 2008.

SILVA, De Plácido e. Vocabulário jurídico conciso. Atual. por Nagib Slaibi Filho e Gláucia Carvalho. 2. ed. atual. Rio de Janeiro: Forense, 2010.

SILVA, Otavio Pinto e. Subordinação, autonomia e parassubordinação nas relações de trabalho. São Paulo: LTr, 2004.

SILVA, Walküre Lopes Ribeiro da. Repensando a cooperativa de trabalho. Revista do Tribunal Regional do Trabalho $15^{a}$ Região, Campinas, n. 10, p. 187-194, jan./mar. 2000.

SOARES FILHO, José. A crise do direito do trabalho em face da globalização. Revista LTr, São Paulo, ano 66, n. 10, p. 1168-1183, out. 2002.

SOUZA, Fernanda Amabile Marinho de. A inconstitucionalidade da atuação sindical na Lei n. ${ }^{\circ}$ 12.023/2009. Revista Síntese Trabalhista e Previdenciária, Brasília, ano 22, n. 259, p. 71-82, jan. 2011.

SOUZA NETO, Antônio de. Cooperativas de trabalho rural. Revista LTr, São Paulo, ano 64, n. 9, p. 1145-1151, set. 2000.

SÜSSEKIND, Arnaldo Lopes. Os princípios do direito do trabalho e a Constituição de 1988. Revista da Academia Nacional de Direito do Trabalho, São Paulo, v. 8, n. 8, p. 111$118,2000$.

- A OIT e o trabalho rural. Revista do Tribunal Regional da $15^{a}$ Região, Campinas, n. esp., p. 69-77, 1995. 
SÜSSEKIND, Arnaldo. Um pouco de história do direito do trabalho. Revista LTr, São Paulo, v. 73, n. 6, p. 647-649, jun. 2009.

; MARANHÃO, Délio; VIANNA, Segadas; TEIXEIRA FILHO, João de Lima. Instituições de direito do trabalho. 20. ed. atual. São Paulo: LTr. 2002. v. 1 e 2.

TAMBELLINI, J. Machado. A nova Lei do trabalho rural. São Paulo: LTr, 1974.

TARSO, Genro. Crise terminal do velho direito do trabalho. Revista do Tribunal Regional do Trabalho da $9^{a}$. Região, Curitiba, v. 21, n. 1, p. 49-53, jan./jul. 1996.

VAISENCHER, Semira Adler; BRANCO, Adélia de Melo. Nem um tostão da previdência social: o caso das bóias-frias idosas no semi-árido irrigado. Revista de Informação Legislativa, Brasília, v. 39, n. 155, p. 93-106, jul./set. 2002.

VENOSA, Silvio de Salvo. Direito civil: contratos em espécie. 11. ed. São Paulo: Atlas. 2011. v. 3.

VIANA, Marcio Tulio. Treze aspectos polêmicos do trabalho rural. IOB: repertório de jurisprudência: trabalhista e previdenciário, São Paulo, n. 18, p. 355-353, set. 1997.

VIANNA, Segadas. O Estatuto do Trabalhador Rural e sua aplicação. Rio de Janeiro: Freitas Bastos, 1963.

VILLATORE, Marco Antonio César. Consórcio simplificado de empregadores rurais. In: GIORDANI, Francisco Alberto da Motta Peixoto; MARTINS, Melchíades Rodrigues; VIDOTTI, Tarcio José (Coords.). Direito do trabalho rural: homenagem a Irany Ferrari. 2. ed. São Paulo. LTr, 2005. p. 430-454.

ZYLBERSTAJN, Hélio. Globalização e regulação do mercado de trabalho no Brasil. São Paulo: Fiesp/Ciesp/IRS, 2000.

A reforma sindical de Lula. Revista de Direito do Trabalho, São Paulo, v. 31, n. 119, p. 94-116, jul./set. 2005. 